\title{
Valuing biological diversity in Navarino Island, Cape Horn Archipelago, Chile - a choice experiment approach
}

\author{
Doctoral dissertation \\ submitted for the degree of \\ Doctor of Agricultural Sciences \\ Georg-August-University of Göttingen (Germany)
}

by

Claudia Cerda

born in Santiago de Chile

Göttingen 2006 
D7

$1^{\text {st }}$ examiner: Prof. Dr. Rainer Marggraf (Göttingen).

$2^{\text {nd }}$ examiner: Prof. Dr. Ulrich Enneking (Osnabrück).

Dates of oral examinations: 3 July 2006, 4 July 2006, 11 July 2006. 
"Biodiversity benefits people through more than just its contribution to material welfare and livelihoods.

Biodiversity contributes to freedom of choice and actions"

(Millennium Ecosystem Assessment 2005)

"It is a mistake to think that economics takes account only for self interested preferences.

It takes account of whatever preferences people have, for whatever reasons they have them"

(Bateman et al. 2002: 20) 


\section{Acknowledgements}

I would like to thank...

* Prof. Dr. Rainer Marggraf for his encouraging and inconditional support, for guiding my work and valuable comments

* Dr. Jan Barkmann for never-ending support and assistance, for motivating and guiding my work, for sharing with me his ideas, for motivating me to write about existence value, for very fruitful discussions - and his patience

Dr. Pablo Villalobos for reminding me to do a $\mathrm{PhD}$

Sandra Rajmis, Jiong Yan, Anne-Kathrin Zschiegner, Susanne Menzel and Linda Schollenberg for their friendship, support, and enjoyable conversations

Rodrigo Saldías, Ricardo Crespo, Daniela Martínez, Rodrigo Zambrano, Andrea Sánchez, Sandra Leiva, Macarena Jordán, Juan Jiménez, Silvia Campos, Carlos Rivera and Christina Seeberg for the enjoyable times in Göttingen and for supporting me during the last phase of my work

Klaus Glenk, Christina Rüffer, Elke Bertke, Manuel Thiel and Jan Freese for constructive conversations and for supporting me during the last phase of the work

Christine Schnorrer for her help and patience

My Chilean assistants Andrés Plaza and Rodrigo Silva for helping me with the interviews

* The BMBF (Federal Ministry of Research and Education) for funding

My BIOKONCHIL project colleagues for fruitful discussions

235 anonymous participants willing to give me the interview in Navarino 
* My family: Roberto, Lucy, Patricia and Lucre for their inconditional love and support from Chile. 


\begin{abstract}
This research aims at contributing at an improved implementation of the Ecosystem Approach of the Convention on Biological Diversity (CBD) by using improved economic instruments that take into account demands stressed by the CBD. These demands are mainly related to the necessity of local participation in conservation management and to the importance of the economic context of conservation. The potential of a Stated Preference Technique, namely a Choice Experiment (CE), is explored. Economic values of biological diversity services of Navarino island, Southern Patagonia, Chile, in the context where the values are not reflected in market processes, are assessed. The specific focus of the investigation are direct and indirect use and existence values.

Ideas of the local population on human-nature relationship were analysed. These local values were used to define biodiversity attributes to be analysed with a choice experiment $(n=230)$. As most development options for Navarino include some loss of biodiversity, mostly increases in income as levels of the monetary attribute (WTA) were offered. Decisions on future development strategies were influenced by: landscape aesthetics threatened by progressing levels of tourist infrastructure $(\mathrm{P}<0.01)$; nature access restrictions due to both economic and conservation concerns $(\mathrm{P}<0.001 ; \mathrm{P}<0.01)$; continued visits of the ethno-culturally important hummingbirds $(\mathrm{P}<0.001)$; protection for an endemic moss $(\mathrm{P}<0.001)$ and ecosystem resilience provided by species diversity (cf. insurance hypothesis) $(\mathrm{P}<0.001)$. The results indicate that $\mathrm{CE}$ has the advantage of isolation of different biodiversity values effectively as people were able to trade-off biodiversity services against a monetary attribute. Validity was supported by meaningful interactions with Protection Motivation Theory (PMT) attitudinal variables. From a non-market valuation perspective local residents favoured a low impact biodiversity scenario, represented by a tourism development at low scale balanced with the protection of species and the cultural ethnic heritage. Results from stated preference methods as an empowering tool to inform participative decisionmaking represents an innovative utilisation of economic mainstream methods for furthering the aims of the Ecosystem Approach.
\end{abstract}




\section{Zusammenfassung}

In dieser Forschung wird eine verbesserte Umsetzung des „Ecosystem Approach“ der Konvention über biologische Vielfalt (CBD) angestrebt, indem verfeinerte ökonomische Instrumente verwendet werden, welche die Anforderungen, die durch das CBD betont wurden, berücksichtigen. Diese Anforderungen sind hauptsächlich mit der Notwendigkeit der Teilnahme der lokalen Bevölkerung am Naturschutz Management und dem Wert des ökonomischen Kontextes des Naturschutzes verbunden. Das Potential einer „Stated Preference“ Methode, spezifisch eines Choice Experiments (CE), wird erforscht. Ökonomische Werte der biologischen Vielfältigkeit der Navarino Insel in Südpatagonien, Chile, werden in dem Kontext, dass diese Werte nicht durch den Markt reflektiert werden, untersucht. Die Untersuchung befasst sich besonders mit den direkten und indirekten Nutz - und Existenzwerten. Die Ideen der lokalen Bevölkerung auf ihr MenschNatur Verhältnis wurden analysiert. Diese lokalen Werte wurden verwendet, um mit einem Choice Experiment die Biodiversitäts-Attribute zu analysieren $(n=230)$. Da viele Entwicklungsmöglichkeiten für Navarino einen Verlust an Biodiversität bedeuten, wurden meistens Einkommenserhöhungen als finanzielles Attribut (Willingness to accept-WTA) angeboten. Entscheidungen über zukünftige Entwicklungsstrategien wurden beeinflusst durch: Landschaftsästhetik, welche durch sich weiterentwickelnde touristische Infrastruktur bedroht wird $(\mathrm{P}<0.01)$; Einschränkung des Zugangs zur Natur durch sowohl ökonomische und Naturschutz Interessen $(\mathrm{P}<0.001$; $\mathrm{P}<0.01)$; anhaltende Besuche des ethnisch-kulturell wichtigen Kolibris $(\mathrm{P}<0.001)$; Schutz für eine endemische Moosart $(\mathrm{P}<0.001)$ und die Widerstandsfähigkeit des Ökosystems durch die Artenvielfalt $(\mathrm{P}<0.001)$ (c.f. Versicherungshypothese). Die Ergebnisse zeigen auf, dass $\mathrm{CE}$ sich als vorteilhaft beweist, um die verschiedenen Biodiversitätswerte in Isolierung zu betrachten, da die Menschen Biodiversitäts-Dienstleistungen und finanzielle Attribute gegeneinander abwägen können. Die Gültigkeit wurde durch eine aussagekräftige Interaktion mit Einstellungs-Variablen der Protection Motivation Theory (PMT) unterstützt. Aus der Nicht-Markt Bewertungs-Perspektive ziehen die lokalen Bewohner das niedrige Auswirkungs-Biodiversitäts Szenarium vor, welches durch eine geringe Tourismusentwicklung verbunden mit dem Arten-und kulturellen Erbschutz dargestellt wurde. Ergebnisse der „Stated Preference“ Methode, welche als Werkzeug dient, um die teilnehmenden Entscheidungsträger zu befähigen, stellt eine innovative Anwendung der öko- 
nomischen etablierten Methoden zur Förderung der Ziele des „Ecosystem Approach“ dar. 


\section{TABLE OF CONTENTS}

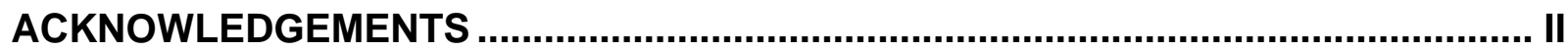

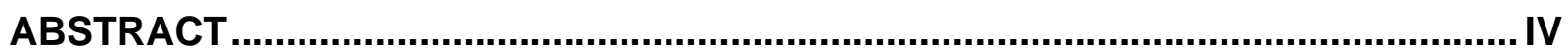

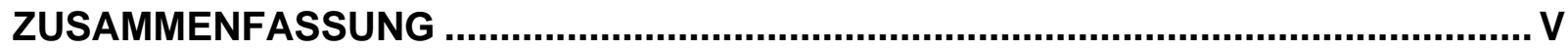

CHAPTER I: INTRODUCTION ……................................................. 5

VALUING BIOLOGICAL DIVERSITY IN NAVARINO ISLAND, CAPE HORN ARCHIPELAGO, CHILE - A CHOICE EXPERIMENT APPROACH 5

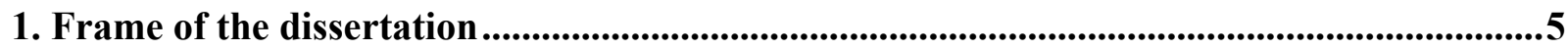

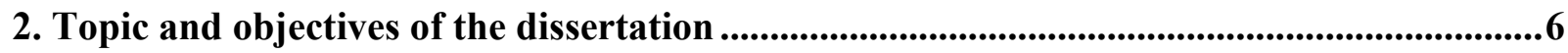

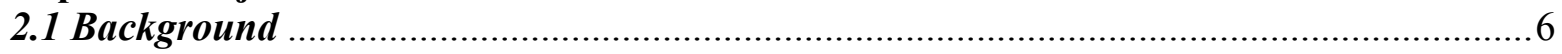

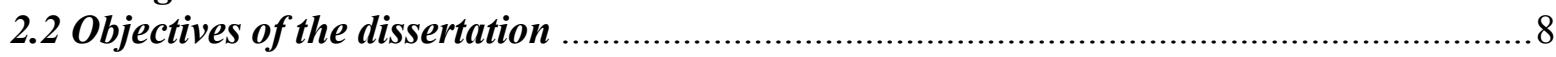

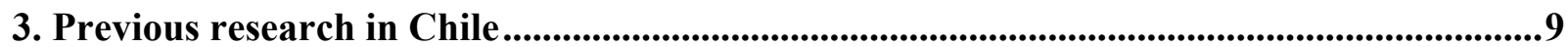

4. Structure of the dissertation ............................................................................................................10

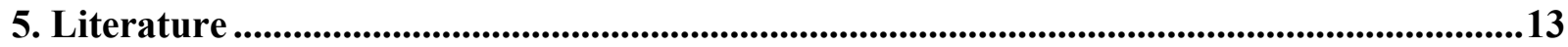

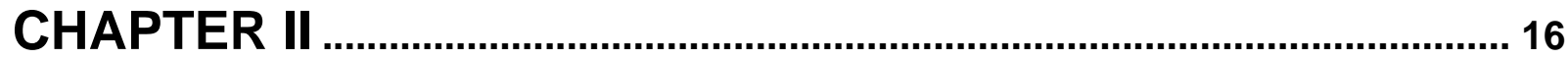

INTERDISZIPLINÄRE ANALYSE VON NATURBILDERN: NOTWENDIGE VORAUSSETZUNG FÜR DIE ÖKONOMISCHE BEWERTUNG DER NATÜRLICHEN UMWELT ........................................................................... 16

Zusammenfassung .............................................................................................................................16

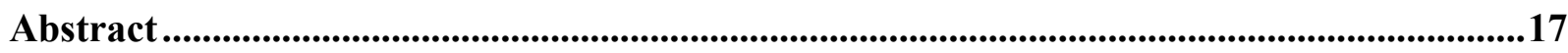

1. Naturbild-Analysen als Bedingung für die Umweltbewertung? .........................................18

2. Umweltökonomischer Hintergrund der Bewertung der natürlichen Umwelt .....................19

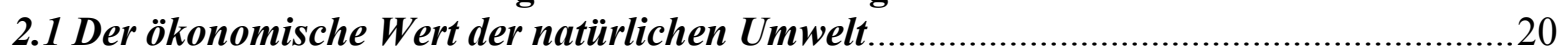

2.2 Ökonomische Behandlung von nicht-nutzungsabhängigen Umweltwerten ....................21 
3. Eine ökonomische Perspektive auf Naturbilder und Naturbildforschung

4. Naturbild-Analyse als notwendige Voraussetzung der ökonomischen Umweltbewertung

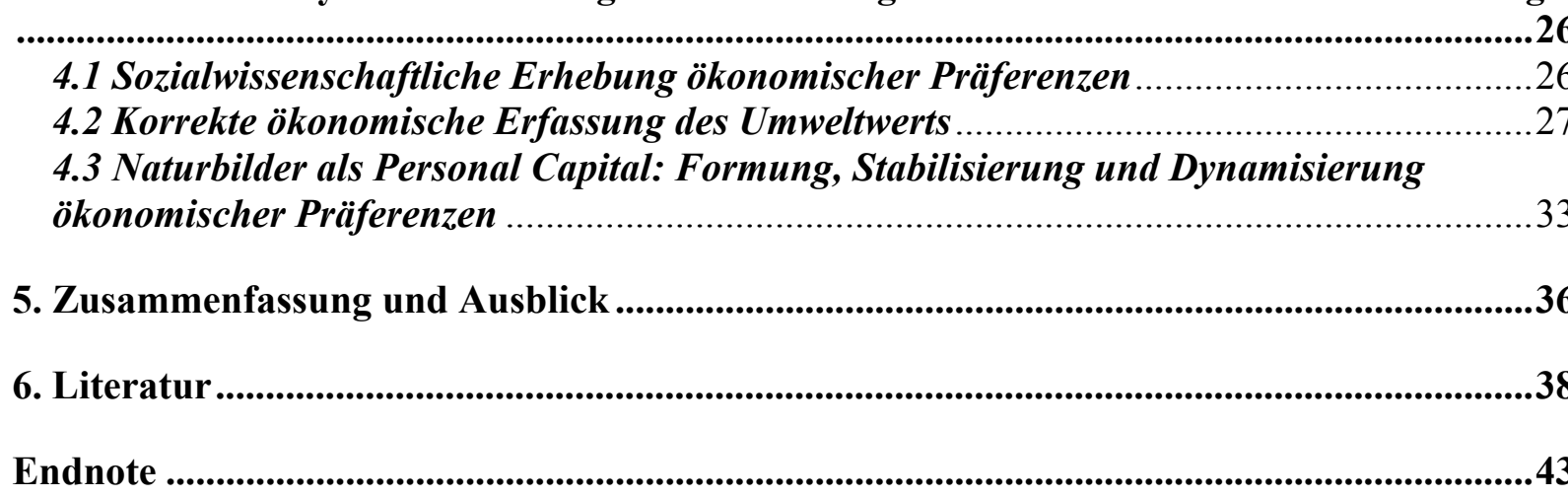

CHAPTER III 44

\section{ECONOMIC NON-MARKET VALUATION OF BIOLOGICAL DIVERSITY OF NAVARINO ISLAND, PATAGONIA (CHILE) IN THE CONTEXT OF THE CBD ECOSYSTEM APPROACH.}

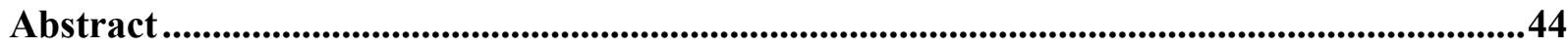

1. Introduction: The Ecosystem Approach of the CBD - economic perspective and participation

2. Methods

2.1 Study area

2. 2 The choice experiment approach: brief introduction to the method ..............................48

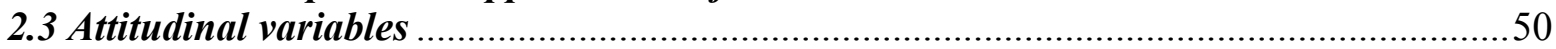

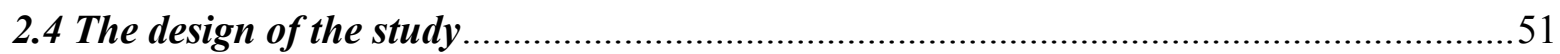

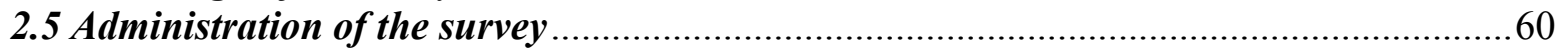

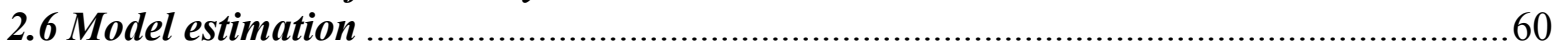

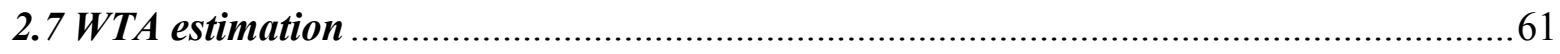

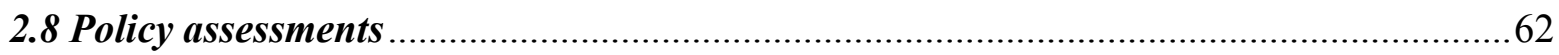

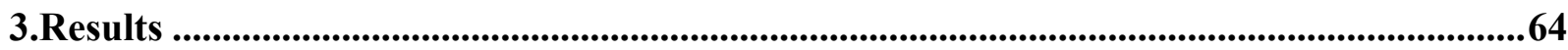

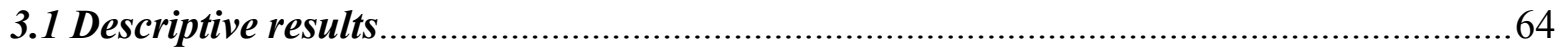

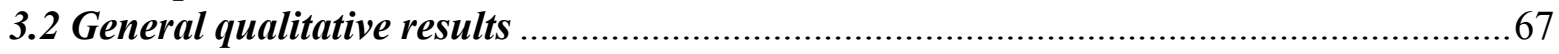

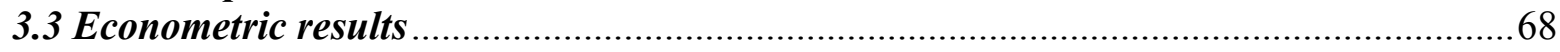

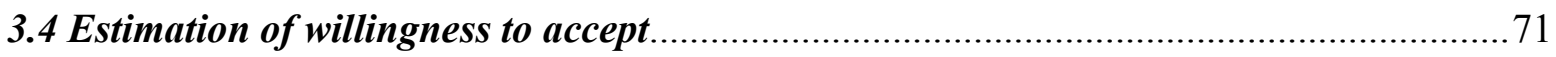

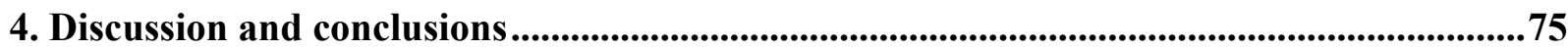

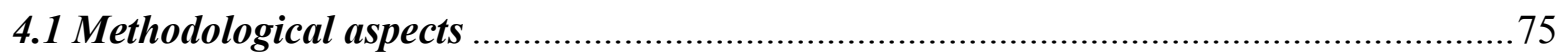

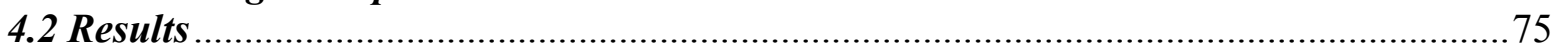




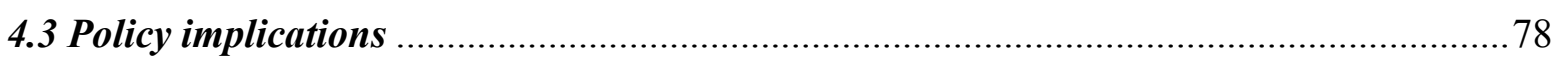

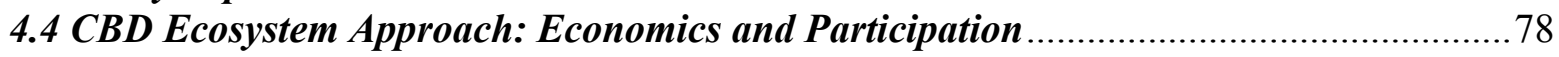

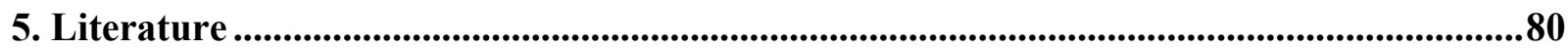

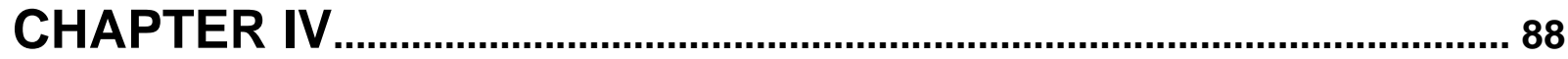

TRADING-OFF THE EXISTENCE OF AN ENDEMIC MOSS? EMPIRICAL RESULTS FROM A CASE STUDY AT THE EXTREME SOUTH OF THE AMERICAS ......................................................................... 88

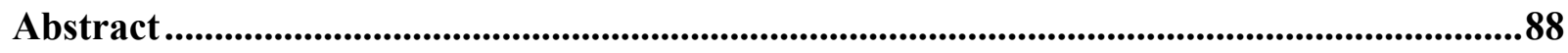

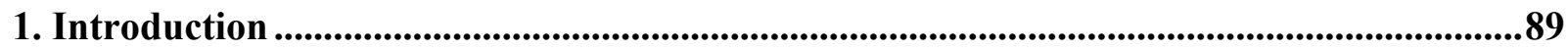

2. Basics of economic existence value ................................................................................................90

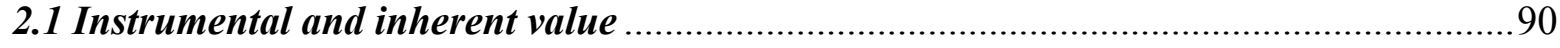

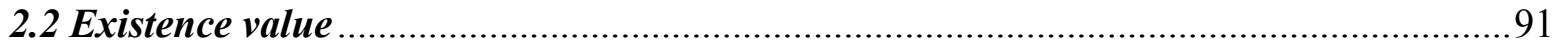

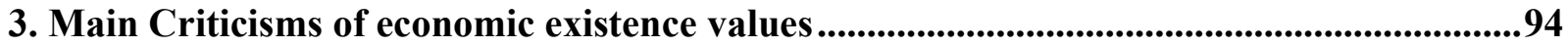

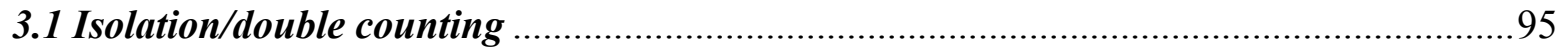

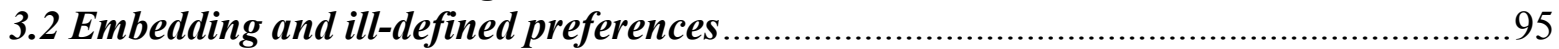

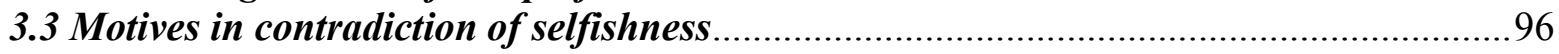

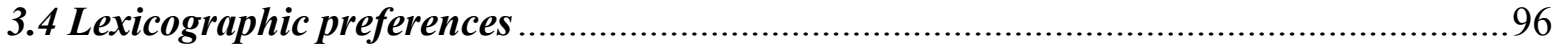

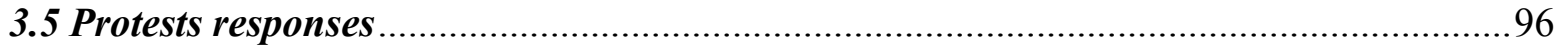

4. Consistent quantification strategy using a choice experiment ..........................................97

5. Case study: Economic existence value of a subanctartic endemic moss in southern Chile

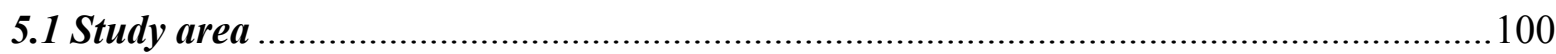

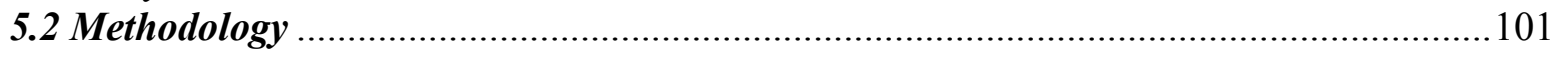

6. Empirical Results .............................................................................................................110

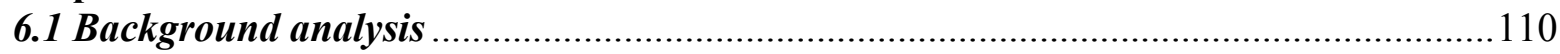

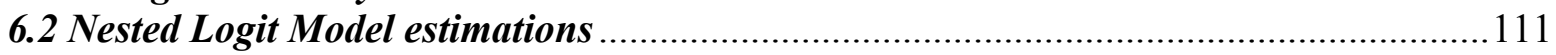

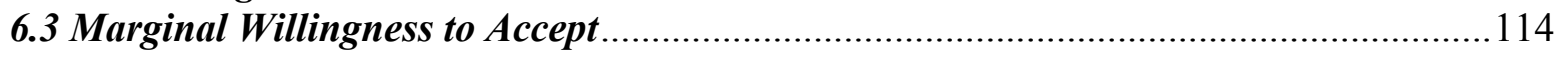

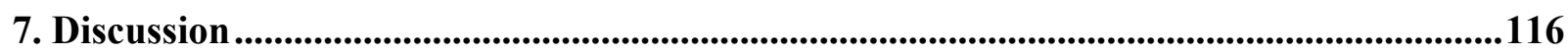

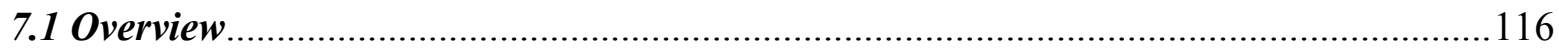

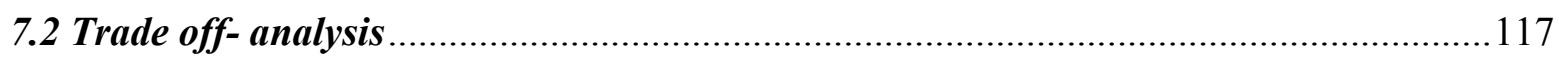

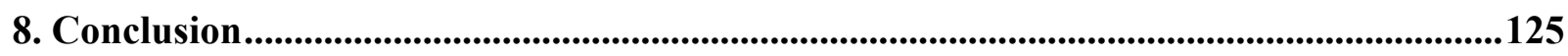

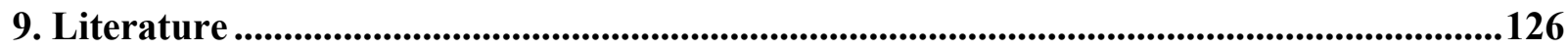




\section{WTPIWTA DESIGN STRATEGIES FOR CHOICE EXPERIMENTS IN EARLY PLANNING STAGES: EXPERIENCES FROM CHILE AND KENYA}

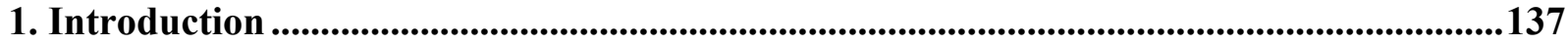

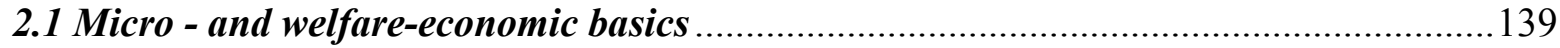

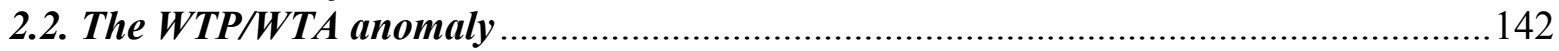

3. Stated preference methods in different planning stages...............................................144

4. Sustainable landscape planning in Chile.............................................................146

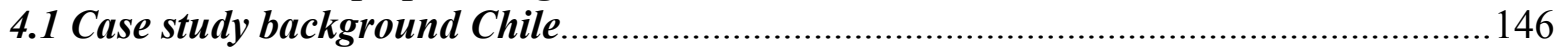

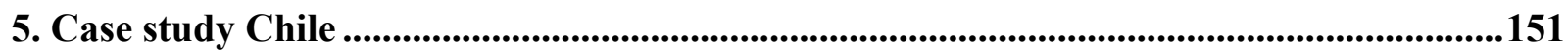

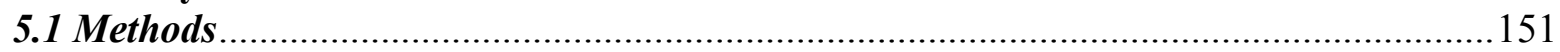

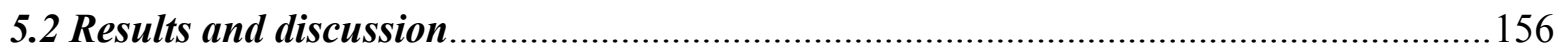

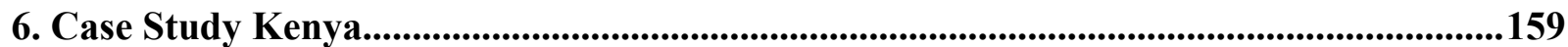

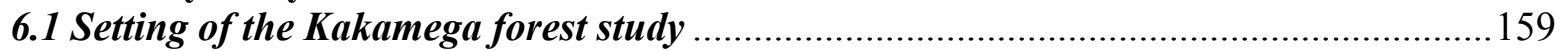

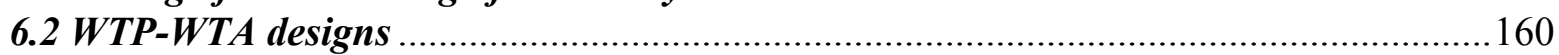

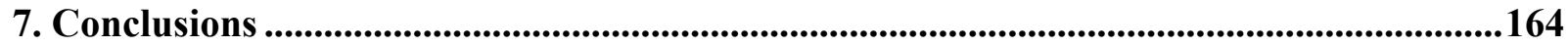

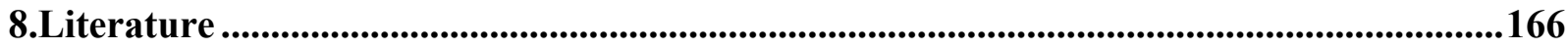

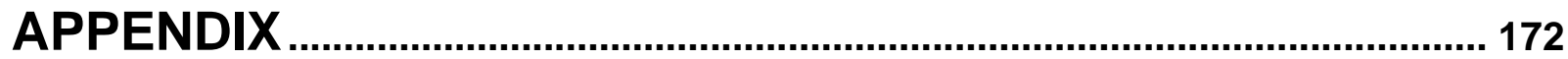

Appendix 1: Choice Experiment Questionnaire ....................................................172

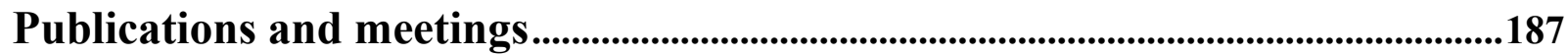

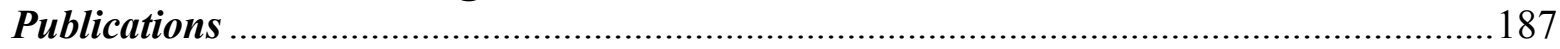

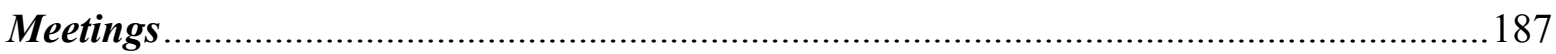

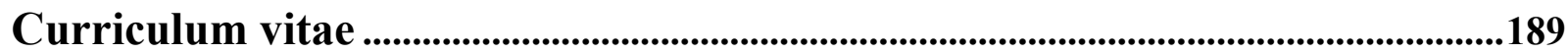




\section{CHAPTER I: Introduction}

\section{Valuing biological diversity in Navarino Island, Cape Horn Archipelago, Chile - a choice experiment approach}

\section{Frame of the dissertation}

The conflict between conservation of biological diversity, on the one hand and its sustainable use, on the other, is well known. In fact, the question how humans can, at the same time, conserve and use biological diversity remains largely unsolved. In this respect, the Ecosystem Approach (EA) of the Convention on Biological Diversity (CBD) provides a framework to take actions that promote the conservation and sustainable use of biological resources. This framework can be particularly useful for those nations around the world in which biological diversity is threatened by subsistence necessities. It is precisely to contribute on this aspect that the German Ministry of Education and Research (BMBF) launched the research programme "Biosphere Research - Integrative and Application Oriented Model Projects" (BioTeam) of which the research presented here is part since 2003. The BioTeam research programme presupposes that conservation and use of biological diversity can only be harmonized if as many interests as possible are taken into account. Since the sustainable biodiversity management is not only matter of science, consideration is also given to political, economic and cultural aspects.

The dissertation was carried out as part of the German - Chilean BioTeam project: "Evaluation of biological diversity under the perspective of the Ecosystem Approach of the Convention on Biological Diversity, on the basis of the example of the island Navarino, southern Chile, Tierra del Fuego, Cape Horn Archipelago" (BIOKONCHIL), from July 2003 to May 2006. BIOKONCHIL aims for a multidisciplinary approach from three disciplines, Ecology, Economics and Environmental Ethics, to contribute to a sustainable development of an island with some one of the world's least disturbed temperate ecosystems (c.f. Rozzi 2003, Rozzi et al. 2004, Jax 2005). Furthermore, BIOKONCHIL aims at the generation of generic knowledge how 
decision-making processes that lead to more sustainable developments in remote areas of threshold countries, such as Chile, can be supported by scientific data.

\section{Topic and objectives of the dissertation}

\subsection{Background}

Biodiversity requires our attention for two reasons. First, it provides a wide range of direct and indirect benefits to humans. Second, humans activities such as resulting in land use change have contributed - and still contribute, to unprecedented rates of biodiversity loss, which threaten the stability and continuity of ecosystems as well as their provision of goods and services to humans (Nunes \& Bergh 2001). This problem has worried to the international community, and diverse forums at the international level have been carried out. In summer 1992 in Rio de Janeiro, the world's nations agreed a global Convention on Biological Diversity (CBD) that aims to protect the world's biological resources. Understanding that biological resources provide the basis for sustainable forms of development in all countries, the CBD calls for national biodiversity strategies and action plans to be developed, acting together in the interests of all humanity (UNEP 1992). These strategies should include multiple approaches covering different biological and socio-economic sub-disciplines. The assessment of the benefits of biodiversity to local people is a key component of successful conservation and sustainable use strategies (Plän 2003: 11). The use of economics tools in support of biodiversity management is indispensable. In this sense, one aspect of great importance for the CBD to be assessed, is the fact that sustainable use of biodiversity may have a positive economic value, and that this economic value may be higher than the value of alternative resource uses which threaten biodiversity (c.f. Pearce \& Moran 1994, Balmford et al. 2002).

Efforts to assess the economic or monetary value of biodiversity play multiple roles in managing the links between human and natural systems. Estimates of marginal biodiversity benefits (see e.g., Balmford et al. 2002) can be used as signals to guide the human use of biological diversity, providing information on the relative scarcity and qualitative condition of the natural environment (Howarth \& Farber 2002). Understanding that biodiversity provides material and experiential benefits that contribute directly to human well-being, it is meaningful and important 
to quantify these benefits in understandable terms (Pearce 1993: 23).

Accounting for this task and understanding that economics can assist in the identification of the policy instruments to be applied to achieve the goal of biodiversity conservation more efficiently (c.f. Marggraf \& Birner 1998), the CBD strongly establishes the importance of the economic context in which conservation activities take place. Almost all of its objectives and articles require the understanding and use of economics for their implementation. Thus, the biodiversity debate has fundamental characteristics: to capture or realize economic value in the context where the values are often not reflected in market processes, and to suggest how these economic values should be taken into decision making (see Pearce \& Moran 1994).

Stated Preference Techniques such as Contingent Valuation (CV) and Choice Experiments (CE) (see e.g., Bateman et al. 2002) provide instruments to elicit economic values where there are no markets associated with the good or service to be valued. Both, CV and CEs use survey questions to elicit statements of value from survey respondents. CV studies, generally, pose written or verbal descriptions of the environmental change to be valued, while CEs pose the change in terms of changes in the attributes of the item to be valued (National Research Council 2005: 119). Since these methodologies can quantify external benefits and costs caused by any kind of economic activity, they can help to allocate resources in an efficient way (Fischer 2003). Moreover they foster participatory public decision making and thus they may contribute to sustainable development (Fisher 2003: 11; see also Bateman et al. 2002, Pearce \& Barbier 2000). For a more extensive overview of these methodologies see e.g., Mitchel \& Carson (1989), Bateman \& Willis (1999), Bennett \& Blamey (2001), Bateman et al. (2002).

The most well known methodology to assess economic values of natural resources is the CV. However, the use of CE is growing, and it is likely to become more prominent in the economic valuation of biodiversity in the future, because of its ability to estimate values for multiple services. Biodiversity provides multiple services, and the ability to estimate marginal values for specific services is important for policy analysis (see Bennett \& Blamey 2001, Bateman et al. 2002, National Research Council 2005). 


\subsection{Objectives of the dissertation}

The research was carried out on the island of Navarino, southern Patagonia, Chile. Recently, Navarino and the two adjacent National Parks were declared a UNESCO Biosphere Reserve. In the widest sense, my research aims at contributing at an improved implementation of the CBD Ecosystem Approach by using improved economic instruments that take into account demands stressed by the CBD. These demands are mainly related to the necessity of local participation in conservation management (UNEP 1998; CBD Ecosystem Approach, Principle 12) and to the importance of the economic context of conservation (UNEP 1998; CBD Ecosystem Approach, Principle 4). Accounting for these demands, the potential of a Choice Experiment (CE) is explored. Economic values of biological resources of Navarino, in the context where the values are not reflected in market processes, are assessed. The focus of the investigation are direct and indirect use, and existence values. From a participatory point of view, the research aimed at improving the opportunities and capacity of the local population to participate actively in the design of a socially, economically and ecologically sustainable future of the island and its inhabitants.

For transferring the mentioned general aims of the dissertation into a specific working program, they are expanded into a more detailed list of particular objectives:

a) Identification of locally relevant sources of indirect and non use benefits related to biodiversity services on Navarino island.

b) Quantification of the local population's valuation for biodiversity services with special emphasis on indirect and existence values.

c) Identification and quantification of perceived trade-offs between different variations of biodiversity benefits.

d) Determination of the influence of variables from Protection Motivation Theory (PMT; c.f. Rogers and Prentice-Dunn 1997) on the valuation of biodiversity services.

e) To contribute to the assessment of sustainable development scenarios based on the revealed stated preferences for biodiversity of the population of Navarino island.

f) To contribute to the discussion on the suitability of a Choice Experiment Approach as a tool for assessing biodiversity existence values.

g) To contribute to the discussion on the suitability of a Choice Experiment Approach as a tool 
for decision making related to biodiversity use and conservation.

\section{Previous research in Chile}

The National Biodiversity Strategy of Chile (c.f. CONAMA 2003) is based on the CBD principles. Under the CBD principles, it is understood that the trend of degradation of the natural environment may be reversed when both, society in general and local communities, obtain benefits from conservation and sustainable use of biological diversity (CONAMA 2003: 5). According to the basis of the National Biodiversity Strategy, different social sectors should participate in the definition and implementation of biodiversity conservation strategies. The state seeks to ensure and promote participation and public consultation with the aim of understanding citizens' interests and needs, in order to build consensus around common objectives and actions (CONAMA 2003: 10). One of the principles of the National Biodiversity Strategy refers to the consideration of environmental services provided by biodiversity: "the contribution of biodiversity as a source of wealth that sustains the many and varied productive activites of society and the general well-being of the population must be taken into account" (CONAMA 2003: 11). In this sense, it is necessary, therefore, to find ways to identify relevant biodiversity services at local and national levels and to incorporate their values into decisions process to secure that they are used sustainablely. The way as citizens value their own biodiversity should constitute an input of great importance to define future strategies of conservation. The development of new methodologies that can complement information to take decisions regarding the use and conservation of biodiversity is urgent.

In Chile, several scientific studies have applied Stated Preference Methods, mainly Contingent Valuation (see De la Maza 1997, Cunazza 2001, Cerda 2003). The main focus has been to value the recreative services inside protected wilderness areas. The National Forest Corporation (CONAF) has used the results to establish new systems of pricing for the National System of Protected Wilderness Areas (SNASPE). Apart from this example, economic valuation approaches are rarely integrated into decisions making process. In this sense, and further to the objetives of the BIOKONCHIL project, the dissertation can help to shed lights on the application of new 
methodologies to value biodiversity in a more extensive expectrum and therefore, to take better informed decisions. The application of new methodologies to value biodiversity can contribute at an improved implementation of the National Biodiversity Strategy in Chile.

\section{Structure of the dissertation}

The dissertation has the character of an accumulative dissertation. Following this introduction, the dissertation is organized in four chapters/manuscripts. The first manuscript (Barkmann et al. 2005), "Interdisziplinäre Analyse von Naturbildern: Notwendige Voraussetzung für die ökonomische Bewertung der natürlichen Umwelt" has been already published in 2005 at Umweltpsychologie. By introducing an interpretation of the "images of nature" concept that is geared towards the applied requirements of the economic valuation of the natural environment, the paper contributes to address the first particular objective (see section 2.2) of the study. The manuscript argues that the methodological standards for stated preference methods require a careful study of the subjective, pre-theoretic cognitive patterns of the respondents with respect to the perception and valuation of nature. An analysis of respondents" "images of nature" is a procedure that yields appropriate data. The study provides an empirical example on Navarino island and shows the links between the images of nature exploration phase and the CE design.

To this manuscript I contributed the empirical example on Navarino island including its images of nature analysis.

The second manuscript: "Economic non-market Valuation of Biological Diversity of Navarino island, Patagonia (Chile), in the context of the CBD Ecosystem Approach" and third manuscript: "Trading-off the existence of an endemic moss?- empirical results from a case study at the extreme South of the Americas", constitute the core of my dissertation. Both manuscripts describe in some detail the work carried out in the field, as well as the econometric and statistical analysis and the interpretation of the results. While co-authorships with J. Barkmann and R. Marggraf acknowledges the close interdisciplinary collaborations within our BIOKONCHIL research team, I am ultimately responsible for the preparation and administration of the study its analysis and interpretation.

All particular objectives of the study (see section 2.2) are addressed in the second manuscript 
which a) outlines the CBD Ecosystem Approach guidelines under which the study was carried out, b) discusses the implementation of a Choice Experiment Approach to value indirect and nonuse biodiversity services on the island of Navarino in Chile, c) gives special emphasis to the importance of local participation aspects in the design of the study, d) explains the empirical exploration of the potential of the Protection Motivation Theory in explaining economic preferences for biodiversity services and e) shows an illustration of the assessment of sustainable development options for Navarino. The study indicates that Choice Experiment can be an empowering tool to inform participative decision-making, furthering, therefore, the aims of the CBD Ecosystem Approach.

Considering the fact that the CBD Ecosystem Approach demands the inclusion of multiple values into biodiversity management, the third manuscript "Trading-off the existence of an endemic moss? - empirical results from a case study at the extreme South of the Americas", describes the assessment of the economic existence value of an inconspicuous moss species, endemic to subAntarctic Patagonia. The manuscript addresses the particular objectives b), c), d) and f) (see section 2.2). The main criticisms related to the economic valuation of existence values are outlined. Additionally, a valuation strategy that takes into account the criticisms is characterized. This is done by productively using an exchange value conception of economic existence value to deal with some of the most discussed problems in attempting to estimate existence values from an economic point of view (lexicographic preferences/protest responses, effective isolation of existence values related to biodiversity, embedding effects). The results indicate that choice experiments can usefully contribute to the economic assessment of existence values by avoiding the main problems in this regard.

The fourth manuscript "WTP/WTA design strategies for choice experiments in early planning stages: Experiences from Chile and Kenya”, results from a collaboration with a BMBF - funded Biota East project affiliated with Zentrum für Entwicklungsforschung (ZEF) in Bonn, and contributes to address the particular objectives e) and g) of the study (see section 2.2). The manuscript discusses the contribution of choice experiments to generate policy advise at early planning stages in which mixed WTP-WTA design strategies are used. Two case studies are presented, one 
in Chile, one in Kenya. Additionally the paper aims to stimulate discussion about the implications of the versatility of choice experiments for public decision making. 


\section{Literature}

Balmford, A., Bruner, A., Cooper, P., Costanza, R., Farber, S., Green, R. E., Jenkins, M., Jefferiss, P., Jessamy, V., Madden, J., Munro, K., Myers, N., Naeem, S., Paavola, J., Rayment, M., Rosendo, S., Roughgarden, J., Trumper, K. \& Turner, R. K. (2002). Economic Reasons for Conserving Wild Nature. Science 297, 950-953.

Bateman, I. \& Willis, K. (eds.). (1999). Valuing Environmental Preferences. Theory and Practice of the Contingent Valuation Method in the US, EU, and Developing Countries. Oxford: Oxford University Press.

Bateman, I., Carson, R., Day, B., Hanemann, M., Hanley, N., Hett, T., Jones-Lee, M., Loomes, G., Mourato, S., Özdemiroglu, E., Pearce OBE, D.W., Sugden, R., \& Swanson, R. (eds.). (2002). Economic Valuation with Stated Preference Techniques: A Manual. Cheltenham: Edward Elgar.

Bennett, J. \& Blamey, R. (eds.). (2001). The Choice Modelling Approach to Environmental Valuation. Cheltenham: Edward Elgar.

Cerda, C. (2003). Beneficios de la recreación al interior de la Reserva Nacional Lago Peñuelas. Tesis para optar al grado de Magíster en Gestión y Planificación Ambiental. Universidad de Chile. Programa Interfacultades.

CONAMA (2003). National Biodiversity Strategy of the Republic of Chile. National Environmental Commission.

Available at : http://www.conama.cl/portal/1255/articles-33717_estrategiaIngles.pdf.

Cunazza, P. (2001). Estimation de beneficios económicos al interior del Parque Nacional Torres del Paine. Región de Magallanes y Antártica Chilena. Tesis Ingeniero Forestal. Departamento de Manejo de Recursos Forestales. Universidad de Chile. 
De La Maza, C.L. (1997). Beneficios Monetarios en Áreas Silvestres Protegidas. Aplicación de los Métodos de Valoración Contingente y Costo de Viaje. Proyecto Corporación Nacional Forestal (CONAF)/Programa de las Naciones Unidas para el Desarrollo (PNUD). Santiago. Chile.

Fischer, A. (ed.). (2003). Decision behaviour and information processing in contingent valuation surveys - an economic psychological analysis of impacts on environmental valuation. Berlin: Verlag im Internet GmbH.

Howarth, R. \& Farber, S. (2002). Accounting for the value of ecosystem services. Ecological Economics 41, 421-429.

Jax, K. (2005). Navarino - ein gefährdetes Inselparadies. In: Roth, S. (Hrsg.): BioTeam - Biodiversitätsforschung für die Anwendung (S. 18-19). Bonn: PT-DLR Umweltforschung.

Marggraf, R. \& Birner, R. (1998). The Conservation of Biological Diversity from a Economic Point of View. Theory Biosci. 117, 289-306.

Mitchell, R. \& Carson, T. (eds.). (1989). Using Surveys to value Public Goods: The Contingent Valuation Method. Washington, D. C.: Resources for the Future.

National Research Council of the National Academies (ed.). (2005). Valuing Ecosystem Services. Toward better Environmental Decision-Making. Washington, D. C.: The National Academic Press.

Nunes, P. \& Bergh, J. C. J. M. (2001). Economic Valuation of Biodiversity: Sense or Nonsense?. Ecological Economics 39, 203-222.

Pearce, D. 1993 (ed.). Economic Values and the Natural World. London: Earthscan. 
Pearce, D.W \& Moran, D. (eds.). (1994). The economic value of Biodiversity. IUCN - The World Conservation Union. London: Earthscan.

Pearce, D. \& Barbier, E. (eds.). (2000). Blueprint for a Sustainable Economy. London: Earthscan.

Plän, T. (2003). From knowledge to action. In: Sustainable use and conservation of biological diversity (pp. 11). Bonn: PT-DLR Umweltforschung.

Rozzi, R. (ed.). (2003). Guía Multi-étnica de Aves de los Bosques Templados de Sudamérica Austral. Magallanes, Chile: Fantástico Sur - Birding \& Nature.

Rozzi, R., Massardo, F. \& Anderson, C. (eds.). (2004). The Cape Horn Biosphere Reserve: A Proposal for Conservation and Tourism to Achieve Sustainable Development at the Southern End of the Americas. Punta Arenas, Chile: Ediciones de la Universidad de Magallanes.

UNEP (1992). Convention on Biological Diversity. Convention text edited by the Secretariat of the Convention on Biological Diversity.

Available at: http://www.biodiv.org/convention/articles.asp.

UNEP (1998). Report of the Workshop on the Ecosystem Approach Lilongwe, Malawi, 26 - 28 January 1998. Submission by the Governments of the Netherlands and Malawi. Available at: http://www.biodiv.org/doc/meetings/cop/cop-04/information/cop-04-inf-09en.pdf. 


\title{
CHAPTER II
}

\section{Interdisziplinäre Analyse von Naturbildern: Notwendige Voraussetzung für die ökonomische Bewertung der natürlichen Umwelt}

\author{
Jan Barkmann, Claudia Cerda \& Rainer Marggraf
}

\section{Zusammenfassung}

Ökonomische Bewertungen gewinnen für die Beurteilung Umwelt-relevanter Projekte an Bedeutung. Die für diese Bewertungen quantitativ oft entscheidenden, nicht-nutzungsabhängigen Werte können jedoch nicht durch die Analyse von Marktdaten ermittelt werden. Stated PreferenceMethoden setzen zu diesem Zweck sozialwissenschaftliche Befragungen ein, die die Zahlungsbereitschaft der Bevölkerung für Naturgüter ermitteln. Wir argumentieren, dass die methodischen Standards für solche Befragungen eine sorgfältige Analyse der subjektiven, vortheoretischen Muster der Wahrnehmung und Bewertung von Natur erfordern. Verfahren, die dies leisten, bezeichnen wir als Naturbild-Analyse. Es wird eine Interpretation des Begriffs „Naturbild“ entwickelt, die auf die angewandten Erfordernisse der ökonomischen Umweltbewertung abgestimmt ist. Naturbild-Analysen sind für die Entwicklung der Erhebungsinstrumente für Stated Preference-Methoden erforderlich und tragen zur Interpretation und inhaltlichen Absicherung der Ergebnisse dieser Methoden bei. Wir illustrieren das vorgeschlagene Vorgehen anhand von Beispielen aus einem laufenden deutsch-chilenischen Forschungsprojekt zur ökonomischen Bewertung biologischer Vielfalt und machen abschießend einen Vorschlag für die Integration von Naturbildern in die ökonomische Theorie. 


\begin{abstract}
Economic valuation gains importance for the assessment of environmentally relevant projects. In economic valuation, non-use values are often decisive. These values cannot be ascertained by the analysis of market data, however. Stated preference techniques use social science surveys to elicit the willingness-to-pay for such non-use values. We argue that the methodological standards for stated preference methods require a careful study of the subjective, pre-theoretic cognitive patterns of the respondents with respect to the perception and valuation of nature. A procedure that yields appropriate data can be called an analysis of the respondents' 'images of nature'. An interpretation of the images of nature concept is introduced that is geared towards the applied requirements of the economic valuation of the natural environment. The analysis of images of nature is not only essential for the development of survey instruments for stated preference methods; it can also contribute to the interpretation and corroboration of the results of such studies. We illustrate the proposed images of nature analysis by examples from a current German-Chilean research project on the valuation of biological diversity, and propose a way to integrate images of nature into economic theory.
\end{abstract}




\section{Naturbild-Analysen als Bedingung für die Umweltbewertung?}

In Kontinentaleuropa gewinnen ökonomische Bewertungen der Folgen von öffentlichen Projekten und Programmen im Vergleich zum angloamerikanischen Raum nur langsam an Bedeutung. Wo immer jedoch das Instrument der volkswirtschaftlichen Nutzen-Kosten-Analyse eingesetzt wird, muss sicher gestellt werden, dass in die Gesamtbewertung auch alle relevanten Projektfolgen eingehen (Hanley \& Spash 1993). Mit dem Total Economic Value-Ansatz (TEV: Pearce 1993, Turner 1999) gibt es zwar einen anerkannten formalen Rahmen, der sicher stellen soll, dass wichtige Teilwerte nicht übersehen werden. Für jede einzelne Anwendung muss jedoch geprüft werden, welche Aspekte tatsächlich in welcher Ausprägung wie wichtig sind. Die Bedeutung qualitativer Vorstudien für diese Untersuchungen wird in der maßgeblichen Literatur zur Durchführung von Befragungen zur Ermittlung des ökonomischen Wertes der natürlichen Umwelt seit Jahren betont (z.B. Mitchell \& Carson 1989, Arrow et al. 1993, Bateman et al. 2002). Die interdisziplinäre Analyse von Naturbildern bietet einen neuen Ansatz für die Systematisierung eines wesentlichen Teils dieser Arbeiten. Hauptthese dieses Beitrages ist es, dass die NaturbildAnalyse in vielen Fällen sogar eine notwendige Voraussetzung für die ökonomische Umweltbewertung ist.

Zunächst umreißen wir die Grundlagen der ökonomischen Umweltbewertung. Der Schwerpunkt liegt auf Umweltwerten, die nicht von einer Nutzung der Natur abhängen (Abschnitt 2). In Abschnitt 3 untersuchen wir verschiedene Ansätze der Naturbildforschung und schlagen eine auf die ökonomische Umweltbewertung abgestimmte Naturbild-Interpretation vor. Anschließend werden zwei wichtige Methoden zur Ermittlung von nicht-nutzungsabhängigen Umweltwerten dargestellt: die Kontingente Bewertung und das Choice Experiment (Abschnitt 4.1). Diese Methoden sind kritischen Nachfragen ausgesetzt, u.a.: Wie kann sicher gestellt werden, (i) dass alle Wertkomponenten korrekt erfasst werden, und (ii) dass der hypothetische Charakter der Befragungsmethoden die Ergebnisse nicht verzerrt? Unsere Eingangsthese werden wir auf den Beitrag der Naturbild-Analyse zu einer umfassenden, den kognitiven Strukturen der Befragten angemessenen Darstellung des zu bewertenden Naturguts stützen (Abschnitt 4.2). Auch zur Diskussion um den hypothetischen Charakter der Befragungen und darüber hinaus zur Stellung der Bewertungsmethoden im gesellschaftlichen Diskurs kann der Naturbild-Ansatz beitragen (Abschnitt 4.3). Wir 
begründen diese weiter gehenden Folgerungen mit einer Identifizierung der Naturbilder mit einem Teilaspekt des Personal Capital, einem zentralen Element der mikroökonomischen Theorie des Nobelpreisträgers für Wirtschaftswissenschaften Becker (1996).

\section{Umweltökonomischer Hintergrund der Bewertung der natürlichen Umwelt}

Einige der Begriffe, die für das Verständnis der ökonomischen Inhalte unseres Beitrages bedeutsam sind, haben wir in Tabelle 1 zusammen gestellt. Die enge Verzahnung unserer Argumentation mit den Ansätzen und Methoden umweltökonomischer Bewertung erfordert jedoch einige zusätzliche Erläuterungen.

Tab. 1: Zusammenstellung wohlfahrtsökonomischer Grundbegriffe.

\begin{tabular}{|c|c|}
\hline Choice Experiment & $\begin{array}{l}\rightarrow \text { Stated Preference-Methode; Ermittlung der Präferenzen durch Auswahl aus Szenarien, } \\
\text { die zu bewertende Veränderungen des } \rightarrow \text { Gutes als Veränderung einzelner Attribute des } \\
\text { Gutes (incl. Kostenattribut) beschreiben. }\end{array}$ \\
\hline Extended Utility Function & $\begin{array}{l}\text { ökonomischer Formalismus; ermöglicht die Theorie-konforme Behandlung der Verände- } \\
\text { rung der } \rightarrow \text { Präferenzen für einzelne } \rightarrow \text { Güter in Abhängigkeit von Veränderungen des } \rightarrow \\
\text { Personal Capital. }\end{array}$ \\
\hline Gut & Gegenstand menschlichen Strebens; auch: Vermeidung von Übeln. \\
\hline Konsumentensouveränität & $\begin{array}{l}\text { normative Idealvorstellung in der Ökonomik nach der KonsumentInnen ihre eigenen Inte- } \\
\text { ressen selbst am besten kennen und die Individuen daher selbst über den Einsatz ihres } \\
\text { Einkommens für Konsumzwecke entscheiden sollen. }\end{array}$ \\
\hline Kontingente Bewertung & $\begin{array}{l}\rightarrow \text { Stated Preference-Methode; Ermittlung der } \rightarrow \text { Präferenzen für eine Veränderung eines } \\
\rightarrow \text { Gutes durch direkte Fragen nach der } \rightarrow \text { maximalen Zahlungsbereitschaft oder } \rightarrow \text { mi- } \\
\text { nimalen Entschädigungsforderung. }\end{array}$ \\
\hline $\begin{array}{l}\text { Kosten, } \\
\text { volkswirtschaftliche }\end{array}$ & $\begin{array}{l}\text { monetärer Wert der Nachteile einer zu bewertenden Veränderung für die Bevölkerung. Die } \\
\text { v. K. entsprechen den } \rightarrow \text { minimalen Entschädigungsforderungen der von der Veränderung } \\
\text { negativ betroffenen Personen. }\end{array}$ \\
\hline $\begin{array}{l}\text { maximale } \\
\text { Zahlungsbereitschaft }\end{array}$ & $\begin{array}{l}\text { Geldbetrag, den eine Person bereit ist, maximal dafür auszugeben, dass eine von ihr positiv } \\
\text { bewertete Veränderung herbei geführt wird (oder eine von ihr negativ bewertete Verände- } \\
\text { rung nicht herbei geführt wird). }\end{array}$ \\
\hline $\begin{array}{l}\text { minimale } \\
\text { Entschädigungsforderung }\end{array}$ & $\begin{array}{l}\text { Geldbetrag, den eine Person mindestens als subjektiven Ausgleich der Nachteile dafür } \\
\text { fordert, dass eine von ihr negativ bewertete Veränderung herbei geführt wird (oder eine } \\
\text { vom ihr positiv bewertete Veränderung nicht herbei geführt wird). }\end{array}$ \\
\hline $\begin{array}{l}\text { Nutzen, } \\
\text { volkswirtschaftlicher }\end{array}$ & $\begin{array}{l}\text { monetärer Wert der Vorteile eines zu bewertenden Projekts für die Bevölkerung. Die } \\
\text { volkswirtschaftlichen Nutzen entsprechen den } \rightarrow \text { maximalen Zahlungsbereitschaften der } \\
\text { von dem Projekt positiv Betroffenen. }\end{array}$ \\
\hline Nutzen-Kosten-Analyse & $\begin{array}{l}\text { Ermittlung und Gegenüberstellung der } \rightarrow \text { volkswirtschaftlichen Nutzen und } \rightarrow \text { volkswirt- } \\
\text { schaftlichen Kosten eines (realisierten oder geplanten) Projekts. }\end{array}$ \\
\hline Personal Capital & $\begin{array}{l}\text { Term der } \rightarrow \text { Extended Utility Function; eine individuelle Bestandsgröße, die sich abhängig } \\
\text { von verschiedensten subjektiven Erfahrungen verändern und die } \rightarrow \text { Präferenzen für Markt- } \\
\text { und Naturgüter beeinflussen kann. }\end{array}$ \\
\hline Präferenzen & $\begin{array}{l}\text { geben die Wertvorstellungen der Individuen wieder; ökonomische Quantifizierung über } \\
\text { Beobachtung von Tauschhandlungen. }\end{array}$ \\
\hline Stated Preference-Methode & $\begin{array}{l}\text { empirische Ermittlung der } \rightarrow \text { Präferenzen für Veränderungen von } \rightarrow \text { Gütern durch Befra- } \\
\text { gungen. Es werden Zahlungs- oder Tauschbereitschaften in grundsätzlich hypothetischen } \\
\text { Befragungssituation beobachtet. }\end{array}$ \\
\hline
\end{tabular}




\subsection{Der ökonomische Wert der natürlichen Umwelt}

Ökonomische Bewertungen sind keine unverbindlichen Werturteile, sondern beanspruchen eine ethische Qualität. Basis ist die ethische Theorie des sozialen Subjektivismus (vgl. Kutschera 1999), die in der ökonomischen Naturbewertung in Form der gesamtwirtschaftlichen Bewertung der Folgen einer Handlung angewandt wird. Eine Handlung ist danach zulässig, wenn sie zu einem positiven gesamtwirtschaftlichen Ergebnis führt; jene Handlung ist vorzuziehen, die das beste gesamtwirtschaftliche Ergebnis erwarten lässt. Die Grundprämissen des sozialen Subjektivismus, aus denen das Prinzip der Konsumentensouveränität abgeleitet ist, müssen nicht geteilt werden ${ }^{1}$. Die Reichweite des Anspruchs ökonomischer Naturbewertungen hängt somit von der Akzeptanz dieser ethischen Prämissen ab. Die Diskussion um die Gültigkeit der Prämissen ist im weiteren jedoch nicht Gegenstand unseres Beitrages.

ÖkonomInnen beschäftigen sich mit Bewertungen, wenn Änderungen zur Diskussion stehen. Bewertet werden nicht Bestände oder Qualitäten von Naturzuständen als solche, sondern Änderungen von Beständen (Zahl der Blauwale) oder Qualitäten (Diversitätsindex eines Biotops). Von Interesse sind Veränderungen, die auf menschliches Handeln zurück gehen. Ökonomische Bewertungen von Handlungen finden in der Regel als Nutzen-Kosten-Analysen statt. Bewertet ein Individuum die Handlung positiv, so wird dessen Interesse an der Handlung durch seine maximale Zahlungsbereitschaft dafür ausgedrückt, dass die Handlung erfolgt. Summiert man alle maximalen Zahlungsbereitschaften auf, so erhält man den volkswirtschaftlichen Nutzen der Handlung. Steht ein Individuum der Handlung ablehnend gegenüber, so ist der Geldbetrag, der das Individuum für die Durchführung der Handlung „kompensiert“, das monetäre Äquivalent der negativen Einschätzung des Individuums.

Nutzen-Kosten-Analysen werden primär für größere öffentliche Politikmaßnahmen durchgeführt. So ging es in der ersten formalen Nutzen-Kosten-Analyse um das Problem, ob der Staat Geld für die Reparatur einer Straße ausgeben solle (Saint Pierre 1708). Saint Pierre (1658-1743) ermittelte den Wert der Straße allein auf Basis der Folgen für die Bevölkerung der an der Straße gelegenen Dörfer und Städte. Auswirkungen auf „staatliche Interessen“ wie die Erleichterung von Truppenbewegungen oder die Steigerung der Straßenzolleinnahmen blieben unbeachtet. Dieser Aspekt gilt noch heute.

\footnotetext{
${ }^{1}$ Die Konstruktion des Wertmaßstabes „maximale Zahlungsbereitschaft“ führt beispielsweise dazu, dass der Einfluss eines Individuums auf das wohlfahrtsökonomische Bewertungsergebnis tendenziell dessen Einkommen proportional ist. Für eine kritische Diskussion der normativen Implikationen siehe z.B. Hanley und Spash (1993).
} 
Die Bewertungsmaße der maximalen Zahlungsbereitschaft und minimalen Entschädigungsforderung wurden von Dupuit (1844) erstmalig eingesetzt. Dupuit beschäftigte sich mit der Bewertung einer Brücke, für deren Überquerung eine Gebühr zu entrichten ist. Bei der Bestimmung des Nutzens der Brücke ging Dupuit davon aus, dass die maximale Zahlungsbereitschaft für jede Brückenüberquerung sukzessive abnimmt. Bei einer bestimmten Anzahl an Überquerungen sinkt die Zahlungsbereitschaft unter die Gebühr - mit der Folge, dass keine weiteren Überquerungen stattfinden. Der gesamte Nutzen der Brücke für ein Individuum entspricht der Summe der jeweiligen Zahlungsbereitschaften bei Brückenüberquerung. Diese Summe ist größer als die Summe der jeweils tatsächlich gezahlten Gebühren. Dieses klassische Beispiel zeigt, dass der ökonomische Wert eines Gutes in der Regel nicht unmittelbar aus der Beobachtung realweltlicher Geldströme bestimmt werden kann. Die maximale Zahlungsbereitschaft ist als Maß des ökonomischen Werts dem Grunde nach ein psychisches Phänomen und keine kaufmännische Buchhaltungsgröße.

\section{2 Ökonomische Behandlung von nicht-nutzungsabhängigen Umweltwerten}

Historisch wurde bei der ökonomischen Naturbewertung zunächst nur die Wertschätzung der NutzerInnen der jeweiligen Naturgüter betrachtet. Ein Interesse an einem Naturgut sollte eine Nutzung zumindest im Sinne physischer Nähe voraus setzen. Es gab daher nur einen nutzungsabhängigen ökonomischen Naturwert. Dies änderte sich als Reaktion auf einen Vorschlag von Friedman (1962), der Staat solle die Errichtung von Nationalparks der Privatwirtschaft überlassen. ,Der Markt' werde dafür sorgen, dass Nationalparks mit positiver Nutzen-Kosten-Bilanz eingerichtet würden. Dieser These wurde entgegen gehalten, dass Personen auch eine Zahlungsbereitschaft für die Einrichtung eines Nationalparks haben können, ohne diesen Nationalpark zu nutzen (nicht-nutzungsabhängiger Wert; Weisbrod 1964, Krutilla 1967, S. 781):

"there are many people who obtain satisfaction from mere knowledge that part of wilderness North America remains even though they would be appalled by the prospect of being exposed to it". 
Aus ökonomischer Sicht ist dieser Hinweis auf die faktischen Interessen ausreichend für die Legitimität nicht-nutzungsabhängiger Wertschätzungen. Nach dem Prinzip der Konsumentensouveränität müssen bei der ökonomischen Bewertung nämlich alle (mit einer Zahlungsbereitschaft versehenen) Interessen berücksichtigt werden. Deshalb ist heute anerkannt, dass der ökonomische Wert der Natur auch durch eine Reihe nicht-nutzungsabhängiger Wertschätzungen gebildet wird, z.B. den Existenzwert und den Vermächtniswert (Marggraf \& Streb 1997). Bei Existenzwerten messen Individuen einer Naturerscheinung allein aufgrund ihrer Existenz einen Wert bei; für Vermächtniswerte ist entscheidend, dass das Umweltgut zukünftigen Generationen zur Verfügung stehen soll.

Das ökonomische Naturbewertungskonzept wird zunehmend von Verwaltungsbehörden und Gerichten übernommen. Insbesondere in den Vereinigten Staaten dient es als Orientierungshilfe für Wertfestsetzungen. So definieren die vom amerikanischen Wirtschaftsministerium veröffentlichten Richtlinien zur Bewertung von Umweltschäden aus Ölunfällen den Wert einer natürlichen Ressource explizit unter Einbeziehung der nicht-nutzungsabhängigen Werte (U.S. Department of Commerce, 1996). Eine groß angelegte Studie zu den nicht-nutzungsabhängigen Werten, die durch das Exxon Valdez-Tankerunglück 1989 vor Alaska beeinträchtigt wurden, schätzte den nicht-nutzungsabhängigen Schaden beispielsweise auf 2,8-4,4 Mrd. US\$ (Carson, Mitchell, Hanemann, Kopp, Presser \& Ruud 1992).

Da Menschen meist nur Güter kaufen, die sie in irgendeiner Form nutzen möchten, gibt es für die Gegenstände der nicht-nutzungsabhängigen Werte keinen Marktpreis. Zudem eigen sich Güter wie die ,Existenz unverschmutzter Küstenökosysteme vor Alaska’ wenig als Gegenstand privater Kaufverträge. Die ökonomische Umweltbewertung kann hier weder direkt noch indirekt auf Marktpreise zurückgreifen. Stattdessen müssen ökonomische Bewertungsmethoden eingesetzt werden, die Zahlungsbereitschaften durch sozialwissenschaftliche Befragungen ermitteln (siehe Abschnitt 4.1).

Der Einsatz sozialwissenschaftlicher Befragungen ist freilich mit methodischen Problemen behaftet. Die Bewältigung dieser methodischen Probleme ist ohne eine interdisziplinäre Zusammenarbeit von Ökonomik und Sozialwissenschaften kaum möglich (vgl. Freeman 2003, S. 182). Zwei wichtige Bereiche für die Zusammenarbeit sind die 
(a) Konzeption und Konstruktion des Messinstruments. Es muss sicher gestellt werden, dass (1) das Instrument eine Zahlungsbereitschaft über alle relevanten Wertkomponenten erfasst, dass (2) die Befragten alle Informationen über den Bewertungsgegenstand verstanden haben, und dass (3) Befragungsartefakte (Biases) möglichst klein gehalten werden;

(b) inhaltliche Absicherung der empirisch gemessenen Naturwertgrößen. Die eingesetzten Methoden konfrontieren die Befragten mit einem hypothetischen Kontext, in dem Fragen zu ihren Handlungsintentionen (= Zahlungsbereitschaften) gestellt werden. Sozialwissenschaftliche Validierungen der Ergebnisse sind geboten, da keine ,objektiven' Markt- oder Nutzungsinformationen zu diesem Zweck zur Verfügung stehen.

Speziell für die ersten beiden unter Punkt (a) aufgezeigten Probleme werden wir zeigen, dass die interdisziplinäre Analyse von Naturbildern methodisch unverzichtbar ist und die Erstellung angemessener Erhebungsinstrumente erleichtert (Abschn. 4.2). Hinsichtlich Punkt (b) betonen wir in Abschnitt 4.3 den Bezug von Naturbildern auf sozialpsychologisch erhebbare Variablen und interpretieren die Naturbilder als Bestandteil des Personal Capital (Becker 1996). Als Bestandteil des Personal Capital betrachtet werfen die Naturbilder zusätzlich ein interessantes Licht auf eines der zu vermeidenden Befragungsartefakte, den Hypothetical Bias (Problem (a-3)).

\section{Eine ökonomische Perspektive auf Naturbilder und Naturbildforschung}

In diesem Abschnitt untersuchen wir zunächst ausgewählte Ansätze der Naturbildforschung, die Potenziale im Hinblick auf die Bewältigung methodischer Probleme der ökonomischen Umweltbewertung besitzen. Auf dieser Grundlage schlagen wir dann eine Naturbild-Definition vor, die auf die Erfordernisse der Umweltbewertung abgestimmt ist.

In ihren „Konturen“ gesellschaftlicher Naturverhältnisse betrachten die Umweltsoziologen Jahn und Wehling (1998) sowohl eine materielle als auch eine symbolische Seite des Mensch-NaturVerhältnisses. Die symbolische „Dimension der kulturellen Deutungen von Natur und Naturverhältnissen“ umfasst dabei nicht nur „religiöse, ästhetische und ethische Bilder und Entwürfe von Natur, sondern auch und vor allem wissenschaftliche Deutungen, Erklärungen und Konstruktionen von Natur“ (Jahn \& Wehling 1998, S. 87-88). Zumindest in den ethischen Bildern und Entwürfen von Natur ist eine evaluative Seite der Naturbilder sichtbar. Der Verweis auf die wissenschaftlichen Deutungen, Erklärungen und Konstruktionen von Natur erschließt die faktisch- 
deskriptive Seite von Naturbildern.

Die Thematisierung dieser beiden Dimensionen korrespondiert mit dem Grundproblem der ökonomischen Umweltbewertung: der Bewertung von zu beschreibenden Umweltveränderungen ${ }^{2}$. Die Analyse von Naturbildern erlaubt einen Einblick in die Subjekt-seitige Verknüpfung von Fakt- und Wertebene, die für die Konstruktion von Erhebungsinstrumenten nutzbar gemacht werden kann. Verstanden als gesellschaftliche Symbolisierungen der Mensch-Natur-Beziehung darf weiterhin damit gerechnet werden, dass die Naturbilder nicht höchst-individuell sind, sondern eine inter-individuelle Komponente aufweisen. Dies öffnet den Weg zur standardisierten Erhebung von Naturbildern (vgl. Kuckarz 2000, Zwick 2002, Krömker 2004).

Gebhard (2001) beschreibt aus entwicklungspsychologisch-psychoanalytischer Sicht die Entstehung von „Weltdeutungen“ bei Kindern und Jugendlichen. In der kognitiven Entwicklung von Kindern herrschen zunächst anthropomorphe bzw. animistische Weltdeutungen vor (Gebhard 2001, S. 55ff). Erst über kognitive Objektivierungsprozesse erfolgt eine gewisse Trennung der beiden Dimensionen. Die kindlichen Affekte bleiben jedoch häufig als „,affektive Unterfütterung“ auch der Weltdeutungen der Erwachsenen bestehen (Gebhard 2001, S. 71, S. 78). Die Weltdeutungen sind daher gleichzeitig kognitive Interpretation der Welt und Ausdruck einer affektiven Beziehung zur Welt. Interpretieren wir diese Weltdeutungen als Naturbilder, erscheinen auch hier faktisch-beschreibende und evaluative Naturbild-Dimensionen angelegt.

Kognitive Konstruktionsprozesse werden von der pädagogischen und didaktischen Vorstellungsund Lernforschung untersucht. Der pädagogische Konstruktivismus (Matthews 1998) geht davon aus, dass alle LernerInnen bereits gewisse Vorstellungen besitzen, bevor sie in einen Lernvorgang eintreten (,pre-concepts“). Die Veränderung dieser Vorstellungen führt oft zur Ausbildung von Hybridvorstellungen. In den Hybridvorstellungen sind die bereits vorhandenen Alltagsvorstellungen eine Mischform mit neu erworbenen Bestandteilen, wissenschaftlicher' Vorstellungen eingegangen (Vosniadou \& Brewer 1992).

In Bezug auf die ökonomische Umweltbewertung sind biologische und ökologische Alltagsvorstellungen über Natur und die Mensch-Natur-Beziehung relevant. Auch diese Alltagsvorstellungen lassen sich als Naturbilder auffassen. Dem Verhalten von Organismen und Ökosys-

\footnotetext{
2 Die ökonomische Umweltbewertung setzt eine von Bewertungen unabhängige Beschreibung der Umweltveränderungen meist unkritisch voraus. Die Beschreibung kann jedoch selbst strittigen, normativ relevanten methodischen Urteilen oder vorgelagerten Werturteilen unterliegen (Baumgärtner 2003). Die idealtypische Trennung von Beschreibung und Bewertung bleibt für die ökonomische Umweltbewertung im Rahmen von Nutzen-Kosten-Analysen dennoch konstitutiv. Wissenschaftsethische Hinweise zum Umgang mit diesem Problem geben beispielsweise Ott (1996) oder Barkmann (2001).
} 
temen wird von Kindern oft eine intentionalistische und vitalistische Kausation zu Grunde gelegt. In einem anthropomorphen oder animistischen Interpretationsrahmen sind intentionale und vitalistische Kausation moralisch unmittelbar relevant. Entsprechend lassen sich unterschiedliche „umweltethische“ Argumenttypen bei Kindern nachweisen (Billmann-Mahecha, Gebhard \& Nevers 1997), die sich auf Komponenten kindlicher Naturbilder zurück führen lassen.

Aus Sicht der Vorstellungs- und Lernforschung erscheint die mentale Trennung der evaluativen und der deskriptiven Dimension von Naturbildern als ein nicht-trivialer Konstruktionsvorgang. Es muss damit gerechnet werden, dass die - wissenschaftlich geforderte - mentale Trennung evaluativer und faktischer Komponenten bei vielen Menschen nicht durchgeführt wird und auch spontan nicht vollständig durchgeführt werden kann. Naturbilder wären dann selbst eine „,vortheoretische" Hybridvorstellung.

Kürzlich legte Krömker (2004) eine umweltpsychologische Untersuchung zum Zusammenhang von Naturbildern und der Akzeptanz von Klimaschutzmaßnahmen vor. Naturbilder werden interpretiert als individuelle, alltagsweltliche, umfassende Muster der Naturwahrnehmung (Krömker 2004, S. 82). Die Operationalisierung der Naturbilder erfolgt über Fragebogenitems zu unterschiedlichen Naturbild-Dimensionen. Clusteranalytisch wurden Studierende aus Deutschland, Peru, Indien und den USA vier Naturbildtypen zugeordnet. Die Auswertung der Antworten auf die Frage „Welches Wort charakterisiert für Sie am besten Natur?" ergab weiterhin, dass in allen vier Kulturen einzelne Naturelemente (Wald, Bäume, Pflanze, Tiere usf.) mit weitem Abstand am häufigsten genannt wurden (Krömker 2004, S. 185f). Die hier zum Ausdruck kommende enge Verbindung von Naturbild mit einzelnen Naturelementen legt es nahe, solche Nennungen zur Identifizierung subjektiv besonders bedeutsamer Naturgüter zu nutzen.

Die umweltsoziologische wie die entwicklungspsychologische Perspektive deuten zusammenfassend auf die enge Verflechtung einer faktischen und einer evaluativen Komponente in Naturbildern hin. Umweltökonomisch ist diese Verflechtung interessant, da ökonomische Bewertungen ebenfalls auf die beiden Komponenten angewiesen sind. Aus Sicht der Vorstellungs- und Lernforschung erscheint eine Entflechtung von Beschreibung und Bewertung eine kognitive Leistung, deren Vollzug nicht durchgängig erwartet werden kann. Da kindliche Naturbilder oft durch eine anthropomorphe und/oder animistische Sichtweise gekennzeichnet sind, liegen hier Beschreibung und Bewertung besonders eng bei einander. Selbst wenn Befragte als Erwachsene später (teilwei- 
se) in der Lage sind, Fakten und Werte in Bezug auf ein Naturgut zu trennen, bleiben kindliche Affekte als affektive Unterfütterung des Naturbildes bestehen.

Unter Bezug auf eine umweltpsychologische Terminologie interpretieren wir Naturbilder daher zusammenfassend als

vortheoretische Muster der Wahrnehmung und Bewertung von Natur und der Mensch-NaturBeziehung, in denen evaluative und deskriptive Anteile nicht oder nur teilweise getrennt vorliegen.

Die obige Formulierung stellt weder an die interne Konsistenz noch an den Umfang der Naturbilder besondere Ansprüche. Im Idealfall lassen sich sicher umfassende, konzeptionell integrierte Naturbilder identifizieren. Aus unserer pragmatischen umweltökonomischen Perspektive treten solche Ansprüche jedoch klar zurück.

\section{Naturbild-Analyse als notwendige Voraussetzung der ökonomischen Umweltbewertung}

\subsection{Sozialwissenschaftliche Erhebung ökonomischer Präferenzen}

Für die ökonomische Bewertung von Naturgütern, für die es keinen Marktpreis gibt, wurden in den vergangenen Jahrzehnten eine Reihe von unterschiedlichen Methoden eingeführt (Pearce 1993, Freeman 2003). Für die Bewertung von Naturgütern, die nicht-nutzungsabhängige Wertkomponenten besitzen, eignen sich strukturell nur sozialwissenschaftliche Befragungsmethoden. Diese Methoden werden als Stated Preference-Methoden bezeichnet, da die Befragten Aussagen zu ihrer Zahlungsbereitschaft treffen (Bateman et al. 2002). Ein wichtiges Einsatzgebiet ist weiterhin die Bewertung von Umwelt- oder Ökosystem-Dienstleistungen, die indirekt in menschliche Produktion oder menschlichen Konsum eingehen. Aktuelle Methodenübersichten geben z.B. Bateman et al. (2002) und Louviere, Hensher und Swait (2001).

Bei Kontingenten Bewertungen wird den Befragten zunächst eine Beschreibung der potenziell von einer Veränderung betroffenen Naturgüter gegeben. Anschließend wird dargestellt, welche Folgen eine bestimmte Planung auf diese Naturgüter hat (,Szenario'). Im einfachsten Fall wird dann gefragt, wie viel die Befragten angesichts ihres verfügbaren Einkommens bereit sind, für den Eintritt oder die Unterlassung der Handlung zu zahlen. Die verschiedenen Möglichkeiten, die 
Frage nach der Zahlungsbereitschaft zu stellen - sowie die Antworten statistisch auszuwerten -, sind Gegenstand intensiver methodischer Debatten (siehe z.B. Degenhardt \& Gronemann 1998, Bateman \& Willis 1999).

Das Choice Experiment geht in den ersten Schritten grundsätzlich ähnlich wie die Kontingente Bewertung vor. Auf eine Beschreibung der betroffenen Umweltgüter folgt eine Beschreibung zu erwartender Veränderungen. Den Befragten wird jedoch nicht ein Szenario präsentiert, sondern meist drei Szenarien gleichzeitig. Jedes der Szenarien ist mit einem „Preisschild“ versehen. Das

dritte Szenario entspricht einer do nothing-Option und ist entsprechend nicht mit gesonderten Kosten verbunden. Die Befragten werden gebeten, jenes Szenario auszuwählen, welches sie unter Berücksichtigung ihrer Einkommenssituation persönlich verwirklicht sehen möchten. Die Beschreibung der Handlungs- oder Planungsfolgen in den Szenarien besteht aus einer kleinen Anzahl an Attributen (Merkmalen), deren Ausprägungen systematisch variiert werden. Aus dem relativen Einfluss, den die verschiedenen Attribute in Vergleich zum Kostenattribut auf die Wahlentscheidungen der Betroffenen ausüben, werden dann die Zahlungsbereitschaften für Veränderungen des Naturguts berechnet.

\subsection{Korrekte ökonomische Erfassung des Umweltwerts}

Der Bezugspunkt für die ökonomische Umweltbewertung ist die Nutzen-Kosten-Analyse zur Projektbewertung. Sobald nicht-nutzenabhängige Werte betroffen sind, erfordert die ökonomische Projektbewertung den Einsatz sozialwissenschaftlichen Befragungsmethoden (siehe oben). Die Einhaltung der Gütestandards der eingesetzten Stated Preference-Methoden (vgl. Arrow et al. 1993, S. 30ff) avanciert damit zu einer notwendigen Bedingung für weite Teilbereiche der ökonomischen Umweltbewertung.

Sowohl die Kontingente Bewertung als auch das Choice Experiment haben eine zutreffende Beschreibung der zu bewertenden Naturgüter zur Grundlage. Eine hinreichend umfassende und hinreichend verzerrungsfreie Bewertung setzt daher eine möglichst vollständige und fehlerfreie Beschreibung der Umweltgüter voraus. Ohne diese Voraussetzung ist mit dem Auftreten systematischer Fehler zu rechnen, die die Validität der Befragungsergebnisse und der Projektbewertung insgesamt in Frage stellen. Wir zeigen die Bedeutung von Naturbild-Analysen im Folgenden unter den Gesichtspunkten einer zutreffenden Identifikation sowie einer angemessenen Repräsenta- 
tion von Naturgütern auf.

\subsubsection{Identifikation der zu bewertenden Naturgüter}

Große Bedeutung kommt der Identifikation der betroffenen Naturgüter $\mathrm{zu}$, dem sogenannten Problem der Commodity Definition (Carson, Flores \& Mitchell 1999). Um die Einbeziehung möglichst aller relevanten Umweltwerte in die Commodity Definition (und damit in die NutzenKosten-Analyse) zu sichern, wird meist der Total Economic Value-Ansatz (TEV) genutzt (Pearce 1993, Turner 1999). Mit der Unterscheidung von nutzungsabhängigen, indirekt nutzungsabhängigen und nicht-nutzungsabhängigen Umweltwerten haben wir bereits von einer wichtigen Unterscheidung innerhalb des TEV Gebrauch gemacht. Weitere Unterscheidungen betreffen Funktions-, Versicherungs-, Options-, und Quasi-Optionswerte.

Sobald die entsprechenden Wertkomponenten des TEV über eine Stated Preference-Methode erhoben werden sollen, muss im Einzelfall bei der Konstruktion des Befragungsinstruments abgeschätzt werden, welche Wertaspekte im Hinblick auf welche Naturstücke quantitativ bedeutsam sind. Die grundsätzliche Durchführung von qualitativen Voruntersuchungen und Pretests gilt zur Vorbereitung von Stated Preference-Studien als der wohl wichtigste, die Reliabilität der Studie beeinflussende Einzelfaktor (Mitchell \& Carlson 1989, S. 218f; siehe auch Arrow et al. 1993, S. 31f, S. 51). Einzelinterviews oder Fokusgruppen sind typischerweise angewandte Methoden der Vorstudienphase. Anhand der Vorbereitung eines Choice Experiments lässt sich besonders gut zeigen, dass an dieser Stelle Naturbild-Analysen erforderlich sind.

Als Naturbild-Analyse fassen wir ein Vorgehen auf, das kulturelle Äußerungen von Individuen oder Gruppen systematisch auf vortheoretische Muster der Wahrnehmung und Bewertung von Natur und der Mensch-Natur-Beziehung hin untersucht (vgl. Abschn. 3).

Die nachfolgenden Ausführungen illustrieren wir mit Beispielen aus dem deutsch-chilenischen BIOKONCHIL-Projekt, das u.a. die ökonomische Bewertung der biologischen Vielfalt der Insel Navarino, Kap Horn/Chile zur Aufgabe hat (Jax 2003). Es arbeiten hier ein ökologisches, ein umweltökonomisches und ein ethisches Teilprojekt zusammen. Nach qualitativen Vorstudien 2003 und im Frühjahr 2004 sowie einer quantitativen Pilotstudie ( $n=45)$ ebenfalls 2004 fand von Januar bis März 2005 die Hauptstudie eines Choice Experiments statt $(n=230)$. Durch die enge Verknüpfung deskriptiver und evaluativer Komponenten bei der Biodiversitätsbewertung bot sich 
die Naturbild-Analyse von Projektbeginn an als integratives Arbeitsfeld für die drei Teilprojekte an. Während für die umweltökonomischen Naturbild-Analysen zunächst die Konstruktion des Erhebungsinstruments im Vordergrund stand, arbeiten die anderen beiden Teilprojekte an einer vertieften, Gruppen-spezifischen Naturbild-Analyse. Diese Ergebnisse werden wiederum zur Interpretation der ökonomischen Bewertungsergebnisse genutzt werden.

Ein entscheidender Schritt in der Entwicklung des Erhebungsinstruments für ein Choice Experiment ist die Auswahl der Merkmale (Attribute), deren Ausprägungen das zu bewertende Naturgut beschreiben. Die kognitiv begrenzte Verarbeitungskapazität der Befragten erzwingt die Beschränkung auf wenige Merkmale, deren Ausprägungen jeweils zu vergleichen sind. Dies erfordert eine Konzentration auf jene Merkmale, die tatsächlich für die Auswahlentscheidungen der Befragten bestimmend sind. Daher sind qualitative Pretests erforderlich, um die Merkmale gezielt auszuwählen, die in enger Beziehung zu den Präferenzen der Befragten stehen (Bateman et al. 2002).

Jede Analyse qualitativen Interviewmaterials in Vorbereitung einer Stated Preference-Studie zu Naturgütern setzt wenigstens implizit eine Naturbild-Analyse ein: Die von den Befragten geäuBerten Wahrnehmungen und Bewertungen von Natur werden auf vortheoretische Muster der Wahrnehmung und Bewertung von Natur hin untersucht. Ziel der Befragung ist es, einen hinreichend umfassenden Einblick in diese Muster zu gewinnen, um quantitativ bedeutsame von voraussichtlich unbedeutsamen Wertkomponenten zu trennen. Nur über diese Art von NaturbildAnalyse kann systematisch sicher gestellt werden, dass die Beschreibung der zu bewertenden Umweltveränderungen tatsächlich auch die quantitativ relevanten Attribute erfasst. Genau dies ist aber ein methodischer Standardanspruch an Stated Preference-Methoden, die für die gesamtwirtschaftliche Projektbewertung genutzt werden sollen (Bateman et al. 2002, S. 258ff; Carson et al. 1999).

Um diesem methodischen Anspruch zu entsprechen, wurden in BIOKONCHIL insgesamt 53 Interviews mit unterschiedlichen EinwohnerInnen-Gruppen durchgeführt. 14 dieser Interviews wurden unmittelbar transkribiert und auf auffällige Häufungen genannter Naturstücke untersucht. Die sich ergebenden Muster wurden mit den restlichen Interviews abgeglichen. Es wurden beispielsweise Fragen nach bekannten, beliebten oder nützlichen Pflanzen, Tieren und Orten gestellt sowie nach bekannten Leistungen oder Vorteilen der Natur für den Menschen (Cerda, Barkmann 
\& Marggraf 2005). Diese offene Herangehensweise erschien auf Navarino besonders wichtig, da die EinwohnerInnen sehr verschiedenen kulturellen Gruppen angehören; u.a. handelt es sich um Angehörige der chilenischen Marine, um bodenständige Fischer, zugereiste ChilenInnen vom Festland (ihrerseits unterschiedlicher ethnischer Herkunft) und Mitglieder der indigenen Yahgan. $\mathrm{Zu}$ den Yahgan lagen beispielsweise bereits Hinweise dafür vor, dass diese traditionell über eine detaillierte Kosmologie verfügen, in der die Metaphern des „Baum des Lebens“ und des „Netzes des Lebens“ eine auch ethisch hohe Bedeutung besitzen (Rozzi 2004).

Exemplarische Ergebnisse der Auswertung der qualitativen Interviews der Vorstudienphase waren (siehe auch Abb. 1):

- Cóndor, Guanaco und Specht (Carpintero) sind die bekanntesten und beliebtesten einheimischen Wildtiere.

- Der nördliche Küstenstreifen der Insel und ein nahe der Inselhauptstadt gelegener Berg (Cerro la Bandera) sind die für Freizeitaktivitäten (Grillen am Strand, Spazieren gehen/Wandern) hauptsächlich genutzten und geschätzten Orte.

- Fast alle befragten InselbewohnerInnen schätzen insbesondere die Ruhe und Schönheit der Landschaft sowie den - in Chile nicht selbstverständlichen - freien Zutritt zur Landschaft für Freizeitaktivitäten.

Diese Ergebnisse haben wir für das Choice Experiment genutzt, um (1) Gegenstände der ästhetischen Wertschätzung auf der Artebene zu spezifizieren, (2) unterschiedliche Zugangsmöglichkeiten zu Inselteilen als Attribut aufzunehmen, sowie (3) die Orte auszuwählen, die in der Wahrnehmung der Bevölkerung vermutlich besonders stark von etwaigen Veränderungen der touristischen Infrastruktur ästhetisch betroffen sind. 


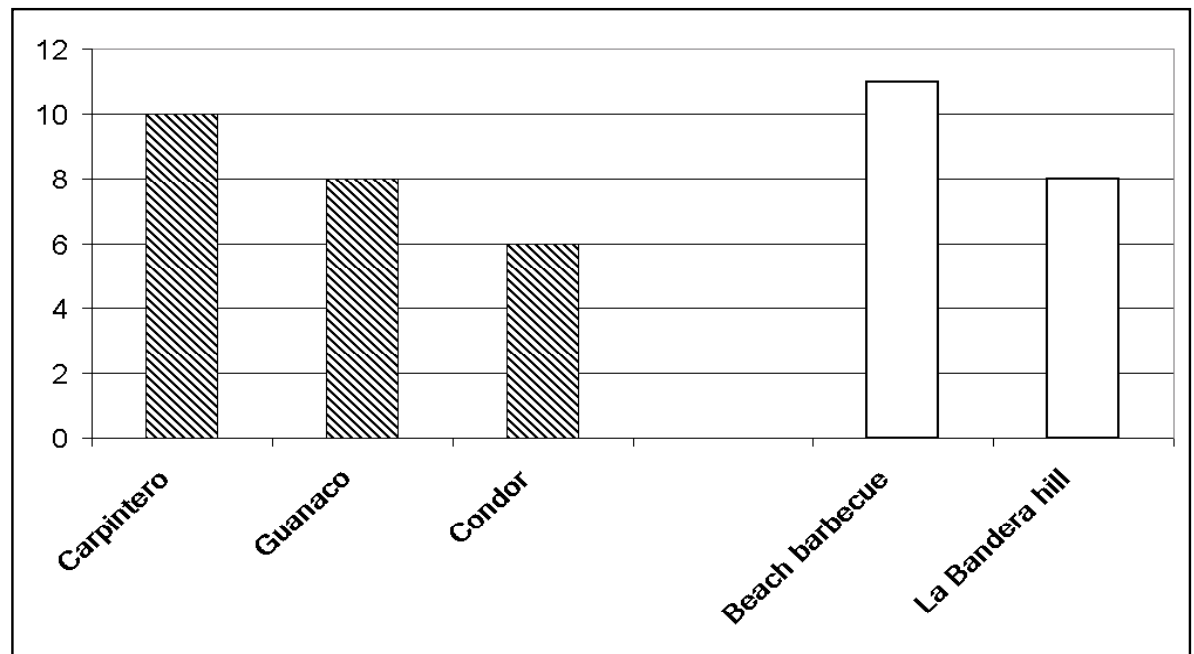

Abb.1: Nennung von bekannten/beliebten einheimischen Tierarten und bekannten/beliebten Orten auf Navarino für die Freizeitgestaltung (quantitative Darstellung von Ergebnissen der qualitativen Vorstudie; n=14; Quelle: Cerda et al. 2005).

Das Erfordernis eine Naturbild-Analyse durchzuführen, gilt in grundsätzlich gleicher Weise für Kontingente Bewertungen (Carson et al. 1999, S. 113). Zwar muss das zu bewertende Naturgut hier nicht in maximal 5-6 Merkmale zerlegt werden. Aber die Begrenzung der kognitiven Verarbeitungs- und Gedächtniskapazität der Befragten erzwingt auch hier eine strenge Auswahl der darzustellenden Projektfolgen. Für beide Stated Preference-Methoden gilt daher:

1. Eine bewusste Berücksichtigung von Naturbildern gibt qualitativen Vorstudien einen hinreichend offenen konzeptionellen Rahmen, der den Befragten weder vorgefertigte Wertkategorien noch eine zunächst künstliche Trennung von Sach- und Wertebene aufzwingt.

2. Ohne zumindest implizite Naturbild-Analysen ist eine ökonomisch hinreichende - d.h. den geltenden methodischen Standards entsprechende - Beschreibung des zu bewertenden Naturguts nicht möglich.

In unserem Fallbeispiel wäre ohne den Naturbild-Ansatz die Detaildarstellung der Attribute (i) zum Vorkommen bekannter und beliebter Arten auf der Insel Navarino und (ii) zu den aus Freizeitsicht besonders sensiblen Orten der Insel deutlich weniger präzise ausgefallen. Wichtiger noch wurde erst auf Grund der Naturbild-Analyse ein Attribut zur freien bzw. beschränkten Zugänglichkeit von Inselteilen überhaupt in die Studie aufgenommen. Die Ergebnisse der Pilotstu- 
die 2004 (Cerda et al. 2005) deuten darauf hin, dass ohne dieses Attribut eine erhebliche Zahlungsbereitschaft in der Größenordnung mehrerer Euro pro Haushalt und Monat übersehen worden wäre.

\subsubsection{Repräsentation der zu bewertenden Naturgüter}

Nicht nur die hinreichende Identifikation sondern auch die Repräsentation der Naturgüter im Befragungsinstrument erfordert eine Naturbild-Analyse. Aus der Kognitionspsychologie ist beispielsweise bekannt, dass begriffliches Denken hierarchisch gegliedert ist (Green \& Tunstall 1999). Wie die Begriffshierarchien innerhalb einer Gruppe von Befragten aufgebaut sind, kann jedoch nicht unmittelbar aus den, wissenschaftlich richtigen' Begriffshierarchien abgeleitet werden.

Green und Tunstall (1999) weisen in diesem Zusammenhang auf den sogenannten Embedding Effect hin (Kahnemann \& Knetsch 1992, Degenhardt \& Gronemann 1998). Embedding Effekte treten auf, wenn unterschiedliche Zahlungsbereitschaften genannt werden in Abhängigkeit davon, ob ein Naturgut einzeln zur Bewertung ansteht oder ob bei der Befragung das Naturgut in ein umfassenderes Güterbündel ,eingebettet' wird. Green und Tunstall (1999, S. 213) vermuten, Embedding Effekte seien „the result of questions which are essentially meaningless to the respondents because [CV studies with embedding effects] make false assumptions about the cognitions of the respondents." Ursache ist eine unzureichende Analyse individueller Bedeutungsgehalte, insbesondere wie das beschriebene Naturgut in die kognitive Kategorienstruktur der Befragten passt. Wissen darüber, wie das zu bewertende Naturgut den Erfordernissen der Bewertungsaufgabe entsprechend innerhalb der subjektiven Begriffssysteme der Befragten dargestellt werden kann, lässt sich ohne eine Analyse der Muster der Wahrnehmung und Bewertung von Natur einschließlich ihrer einzelnen Elemente schwerlich gewinnen. Erneut waren es daher die Ergebnisse der Vorstudieninterviews, deren Analyse wir der Darstellung der Attribute im BIOKONCHILChoice Experiment zu Grunde legten.

Bei bewusster Auswahl und Darstellung des Naturguts aufgrund einer Naturbild-Analyse lässt sich der Embedding Effekt vermutlich auch konstruktiv nutzen: Sind beispielsweise die ästhetisch wichtigsten einheimischen Tierarten der Insel Navarino identifiziert (Cóndor, Guanaco, Carpintero), wird ein Bewertungsszenario, das diese Arten enthält, den größten Teil der Zah- 
lungsbereitschaft für eine häufigere Sichtung aller ästhetisch bedeutsamen heimischen Tierarten abgreifen. Ähnlich gehen wir davon aus, dass ein Attribut zum Existenzwert einer einzelnen Art - hier eines endemischen sub-antarktischen Mooses - einen großen Teil der gesamten Zahlungsbereitschaft aktiviert, die auf einem ethisch motivierten Impuls zum Artenschutz beruhen. Dieses Vorgehen ermöglicht eine kompakte und gleichzeitig sehr konkrete Gestaltung der Bewertungsszenarien. Eine methodisch streng abgesicherte Überprüfung dieser aus der Naturbild-Diskussion entstammenden Überlegungen liegt jedoch jenseits der Aufgabenstellung des BIOKONCHILProjekts.

\subsection{Naturbilder als Personal Capital: Formung, Stabilisierung und Dynamisierung ökonomi- scher Präferenzen}

Eine orthodox-ökonomische Kritik an der Anwendung sozialwissenschaftlicher Befragungen zur Ermittlung ökonomischer Werte weist auf den hypothetischen Charakter der Befragungen hin (vgl. Mitchell \& Carson 1989, S. 27ff). Ökonomische Aussagen seien aus der Untersuchung tatsächlichen (Markt-) Verhaltens abzuleiten. Eine Linie der Kritik an Stated Preference-Methoden vermutet entsprechend, dass viele Befragte vor der Befragung überhaupt keine ausgearbeiteten Präferenzen für die zu bewertenden Güter besitzen (Sugden 1999). Stated Preference-Methoden würden daher keineswegs bereits vorliegende, stabile Präferenzen aufdecken. Erschwert werde das Problem dadurch, dass die Befragten einer hypothetischen Befragungssituation ausgesetzt würden. Dies könne dazu führen, dass Bewertungsaussagen unkontrollierbar stark verzerrt seinen (Hypothetical Bias). Angesichts derartiger Kritik ist eine zusätzliche Validierung und konzeptionelle Absicherung der Ergebnisse von Stated Preference-Befragungen wünschenswert.

Betrachten wir zunächst den Vorwurf des Hypothetical Bias. Die Einbeziehung von Einstellungskonstrukten gegenüber Natur und Umwelt wird bereits vom mit mehreren ÖkonomieNobelpreisträgern besetzten NOAA Panel gefordert (Arrow et al. 1993, S. 34f). Insbesondere geeignet ist die Interpretation von Zahlungsbereitschaften als Handlungsintentionen und deren Erklärung durch die Konstrukte sozialpsychologische Handlungstheorien. Gelingt eine zufrieden stellende Erklärung der Zahlungsbereitschaften für die zu bewertenden Naturgüter, ist dem Einwand des Hypothetical Bias die Spitze genommen, da die Intention zur tatsächlichen Zahlung 
unabhängig untermauert wird. Die Studie von Krömker (2004) weist einen Weg, wie Naturbilder in diesem Zusammenhang nutzbar gemacht werden können. Sie testete den Einfluss einer Einteilung der Befragten nach deren vorherrschenden Naturbildern auf verschiedene Konstrukte sozialpsychologischer Handlungstheorien. Ein direkter Einfluss zeige sich auf Variablen der Wahrnehmung und Bewertung des Klimawandels. Diese Variablen beeinflussten ihrerseits die handlungsnahen Konstrukte der Akzeptanz von Klimaschutzmaßnahmen. In BIOKONCHIL gehen wir einen etwas anderen Weg, indem wir der Erklärung der Zahlungsbereitschaften die Schutzmotivations-Theorie nach Rogers zu Grunde legen (Rogers \& Prentice-Dunn 1997). In einer gewissen Parallelität zum Naturbild-Ansatz der Cultural Theory (Douglas \& Wildavsky 1982) steht hier die Mensch-Umwelt-Beziehung unter den Gesichtspunkten von Risiko und Risikobewältigung im Mittelpunkt.

Wie sieht es mit dem Problem der mangelnden Differenzierung und zeitlichen Stabilität der Präferenzen aus? Umweltpsychologisch erscheint auch hier eine formende und stabilisierende Wirkung von Naturbildern auf erfragte Präferenzen durchaus plausibel. Naturbilder sind Teil des kulturellen Kontextes von Umwelthandeln (Krömker 2004, S. 84). So wie allgemeine subjektive Werte eine Kontextfunktion für konkrete Einstellungen ausüben - beispielsweise zu Umweltthemen wie Biodiversität, Wasser oder Klima -, wird dies auch für die Naturbilder vermutet. Eine solche Bedeutung liegt auch ökonomisch nahe. Die längerfristig stabilen Muster der Wahrnehmung und Bewertung von Natur könnten einen Rahmen bieten, in dem Präferenzen (= Zahlungsbereitschaften) für Naturgüter artikuliert werden.

Lässt sich diese Vermutung in einen anerkannten ökonomischen Theorierahmen integrieren? Ein Ansatzpunkt ist das erweitete Präferenzmodell von Becker (1996; vgl. auch Rogeberg 2003). Es handelt sich um ein generalisiertes Modell rationalen Handelns, das auf die Erklärung von NichtMarktverhalten einschließlich von Sucht und Gewohnheiten ausgelegt ist. Es wird anerkannt, dass Präferenzen für einzelne Güter nicht stabil sind, sondern von den Erfahrungen abhängig sind, die ein Mensch macht. Diese Erfahrungen prägen in der Terminologie Beckers das Personal Capital des Individuums. Zu diesen Erfahrungen zählen der Konsum von Gütern, aber auch die Erfahrungen mit Erziehung und Werbung. Die Ausbildung von Präferenzen für die einzelnen Güter ist dabei kein ausschließlich passiver Prozess. Menschen beeinflussen ihren Erfahrungsschatz aktiv - z.T. mit dem Ziel, die eigenen Präferenzen zu ändern. 
Die Präferenzstruktur eines Individuums für Markt- und Naturgüter kann in Anlehnung an Becker anhand einer Extended Utility Function beschrieben werden: ${ }^{3}$

$\mathrm{U}=\mathrm{f}(\mathrm{x}, \mathrm{z}, \mathrm{P})$ mit

$\begin{array}{ll}\text { U: } & \text { Nutzen eines Individuums } \\ \text { x: } & \text { Konsum von Marktgütern } \\ \text { z: } & \text { Konsum von Naturgütern } \\ \text { P: } & \text { Personal Capital }\end{array}$

Das hier interessierende Personal Capital beinhaltet den früheren Verbrauch des Individuums und andere subjektive Erfahrungen, die dessen Präferenzen für die einzelnen Marktgüter x und Naturgüter $\mathrm{z}$ beeinflussen. Die Extended Utility Function als solche wird als stabil gedacht. Änderungen des Personal Capital $\Delta \mathrm{P}$ können hingegen - bei konstanter Extended Utility Function! - zu einer Veränderung des Nutzens aus dem Konsum der verschiedenen Güter x und z führen.

Diese dynamische Dimension des Personal Capital hat neben den stabilisierenden Effekten (s.u.) besondere Relevanz. Erste Auswertungen der BIOKONCHIL-Ergebnisse der Pilotstudie hatten beispielsweise keine Zahlungsbereitschaft zur Verhinderung zusätzlicher touristischer Infrastruktur auf der Insel nachweisen können (Cerda et al. 2005). Eine wesentliche Aktivität von BIOKONCHIL ist es nun jedoch, den lokalen Diskurs um nachhaltige Entwicklungsziele für die Bereiche Tourismus und Naturschutz mit wissenschaftlichen Daten zu unterstützen. Hierzu gehört die Abschätzung und Visualisierung der ökologischen Folgen weiterer touristischer Entwicklung auf der Insel. Zu mindest bei einem Teil der BewohnerInnen könnte dieser Diskurs zu Lerneffekten führen, die deren Personal Capital verändern. Das Ergebnis könnte sich dann als Erhöhung der Präferenzen für das Naturgut „unverbaute Landschaft“ niederschlagen.

Naturbilder lassen sich in der Becker'schen Konzeption zwanglos als ein Teil des Personal Capital interpretieren. Naturbilder sind durch Erfahrung gebildet und (meist langsam) durch Erfahrung änderbar. Als übergeordnete, umfassende Muster der Wahrnehmung und Bewertung von Natur und der Mensch-Natur-Beziehung wirken die Naturbilder auf die Ausbildung von Präferenzen für einzelne Naturgüter $\mathrm{z}$ - wie sie beispielsweise von Stated Preference-Methoden erfragt

3 Die Extended Utility Function enthält außerdem noch das Social Capital, das das „Verhalten der anderen“ incl. der Wirkung gesellschaftlicher Institutionen fasst. Aus Vereinfachungsgründen haben wir das Social Capital hier fort gelassen. 
werden. Selbst wenn vor Beginn einer Befragung keine konkreten Präferenzen für ein Naturgut vorlagen, werden diese nicht völlig zufällig während der Befragung erzeugt, sondern unter Bezugnahme auf das je individuelle vortheoretische Muster der Wahrnehmung und Bewertung von Natur und der Mensch-Natur-Beziehung gebildet. Da die Naturbilder als komplexe psychische Strukturen eher langsamen Veränderungen unterworfen sein sollten (vgl. Abschn. 3.2 und 3.3), kommt ihnen ein formender und stabilisierender Einfluss auf die geäußerten Wertschätzungen im Rahmen von Stated Preference-Methoden zu.

\section{Zusammenfassung und Ausblick}

Wann immer ökonomische Umweltbewertungen auf sozialwissenschaftliche Befragungsmethoden zurück greifen, weil nicht-nutzungsabhängige Werte zu berücksichtigen sind, müssen zumindest implizite Analysen der Naturbilder der Befragten angestellt werden. Auch für die inhaltliche Validierung der Befragungsergebnisse bietet die Kombination aus Naturbild-Ansatz und sozialpsychologischen Handlungstheorien ein gewisses Potenzial. Naturbilder erscheinen ökonomisch weiterhin als Teil des kurzfristig stabilen, aber langfristig änderbaren Personal Capital (Becker 1996). Naturbildern kommt somit eine wichtige formende und stabilisierende Funktion für ökonomische Präferenzen für Naturgüter zu, da Naturbilder als ein sich nur langsam ändernder Bestandteil des Personal Capital aufgefasst werden können. Diese Argumentation trägt zur Entkräftung verbreiteter Einwände gegen die Anwendbarkeit von Stated Preference-Methoden für die Bewertung von Naturgütern bei, für die die Befragten vorab nicht über differenzierte Präferenzmuster verfügen.

Im Hinblick auf die Anwendung ökonomischer Bewertungsmethoden in Prozessen Nachhaltiger Entwicklung ist zusätzlich die dynamisierende Funktion von Naturbildern im Hinblick auf ökonomische Präferenzen bedeutsam. Die Convention on Biological Diversity fordert ebenso wie die Agenda 21 eine Einbeziehung der Betroffenen von Umwelt- und Naturschutz-relevanten Projekten. Demokratietheoretisch - wie vermutlich langfristig auch aus Akzeptanzgründen - sollen Entscheidungen über Ziel, Art und Umfang der Projekte möglichst partizipativ erfolgen. Nicht selten stehen sich in der gesellschaftlichen Auseinandersetzung jedoch Gruppen gegenüber, die unterschiedliche Vorstellungen („Bilder“) von der Natur und der idealen Mensch-Natur-Beziehung haben. Im Idealfall befördert der Austausch über die wechselseitigen Naturbilder der Betroffenen 
- sowie ihrer ökonomischen Bewertungen - die Entwicklung konsensual getragener Bewertungen und Maßnahmen (vgl. z.B. discourse-based valuation: Wilson \& Howarth 2002). Das Ergebnis eines intensiven Diskurses um eine ,richtige' oder , angemessene' Mensch-Natur-Beziehung lässt sich wiederum als veränderte (oder unveränderte) Präferenzstruktur mit Stated PreferenceMethoden nachweisen (Cerda et al. 2005). Der Becker'sche Ansatz des Personal Capital weist hier einen Weg, nicht nur die Stabilität sondern auch die Dynamik individueller Naturbilder für die umweltökonomische Theorie und Praxis nutzbar zu machen. 


\section{Literatur}

Arrow, K., Solow, R., Portney, P.R., Learner, E.E., Radner, R. \& Schuman, H. (1993). Report of the NOAA Panel on Contingent Valuation. Washington, D.C.: Resources for the Future.

Bateman, I.J \& Willis, K.G. (eds.) (1999). Valuing Environmental Preferences - Theory and Practice of the Contingent Valuation Method in the US, EU, and Developing Countries. Oxford (UK): Oxford University Press.

Bateman, I.J., Carson, R.T, Day, D, Hanemann, M., Hanley, N., Hett, T., Lones-Lee, M., Loomes, G., Mourato, S., Özdemiroglu, E., Pearce, D.W., Sugden, R. \& Swanson J. (2002). Economic Valuation with Stated Preference Techniques - A Manual. Cheltenham (UK): Edward Elgar.

Baumgärtner, S. (2003). Warum Messung und Bewertung biologischer Vielfalt nicht unabhängig voneinander möglich sind. In Weimann, J., Hoffmann, S. \& Hoffmann, A. (Hrsg.): Messung und ökonomische Bewertung von Biodiversität - Mission impossible? (S. 43-66). Marburg: Metropolis.

Barkmann, J. (2001). Modellierung und Indikation nachhaltiger Landschaftsentwicklung - Beiträge zu den Grundlagen angewandter Ökosystemforschung. EcoSys 9, 1-61.

Becker, G.S. (1996). Accounting for Tastes. Cambridge (MA): Harvard University Press.

Billmann-Mahecha, E., Gebhard, U. \& Nevers, P. (1997). Naturethik in Kindergesprächen. Grundschule 29(5), 21-24. 
Carson R.T., Mitchell, R.C, Hanemann, W.M., Kopp, R.J., Presser, S. \& Ruud, P.A. (1992). A Contingent Valuation Study on Lost Passive Use Values Resulting from the Exxon Valdez Oil Spill. A Report to the Attorney General of the State of Alaska. http://www.evostc.state.ak.us/pdf/econ5.pdf (abgerufen am 20.12.2004).

Carson, R.T., Flores, N.E. \& Mitchell, R.C. (1999). The Theory and Measurement of Passive-Use Value. In: Bateman, I. \& Willis K.G. (eds.): Valuing Environmental Preferences: Theory and Practice of the Contingent Valuation Method in the US, EU, and Developing Countries (pp. 97-130). Oxford (UK): Oxford University Press.

Cerda, C., Barkmann, J. \& Marggraf, R. (2005). Assessment of Biological Diversity in the Context of the CBD Ecosystem Approach: The Participatory Potential of Economic Valuation Techniques. Poster presentation at the international conference "Biodiversity: Science and Governance", Paris, January 24-28, 2005.

Degenhardt, S. \& Gronemann, S. (1998). Die Zahlungsbereitschaft von Urlaubsgästen für den Naturschutz: Theorie und Empirie des Embedding-Effektes. Frankfurt/M.: Lang.

Douglas, M. \& Wildavsky, A. (1982). Risk and Culture: An Essay on the Selection of Technical and Environmental Dangers. Berkeley (CA): University of California Press.

Dupuit, J. (1844). De la Mesure de 1'Utilité des Travaux Public. Zitiert nach der englischen Übersetzung „On the measurement of the utility of public works”. International Economic Papers (1952), 2, 83-110.

Friedman, M. (1962). Capitalism and Freedom. Chicago (IL): University of Chicago Press.

Freeman, A.M. (2003). The measurement of Environmental and Resource Values: Theory and Methods. $2^{\text {nd }}$ ed. Washington, D.C.: Resources for the Future. 
Gebhard, U. (2001). Kind und Natur - Die Bedeutung der Natur für die psychische Entwicklung. 2. erw. u. akt. Auflage. Wiesbaden: Westdeutscher Verlag.

Green, C. \& Tunstall, S. (1999). A Psychological Perspective. In: Bateman, I. \& Willis K.G. (eds.): Valuing Environmental Preferences: Theory and Practice of the Contingent Valuation Method in the US, EU, and Developing Countries (pp. 207-257). Oxford (UK): Oxford University Press.

Hanley, N. \& Spash, C.L. (1993). Cost-Benefit Analysis and the Environment. Cheltenham (UK): Edwar Elgar.

Jahn, T. \& Wehling, P. (1998). Gesellschaftliche Naturverhältnisse - Konturen eines theoretischen Konzeptes. In Brandt, K.-W. (Hrsg.): Soziologie und Natur - Theoretische Perspektiven (S. 75-96). Opladen: Buderich + Leske.

Jax, K. (2003). BIOKONCHIL - Evaluation of Biological Diversity under the perspective of the Ecosystem Approach of the Convention on Biological Diversity, on the basis of the example of the island Navarino. In Sustainable use and conservation of biological diversity (pp: 374375). Bonn: PT-DLR Umweltforschung.

Kahneman, D. \& Knetsch, J.L. (1992). Valuing Public Goods. The Purchase of Moral Satisfaction. Journal of Environmental Economics and Management 22, 57-70.

Krömker, D. (2004). Naturbilder, Klimaschutz und Kultur. Weinheim: Beltz.

Kuckarz, U. (2000). Umweltbewußtsein in Deutschland. Berlin: Umweltbundsamt.

Krutilla, J.V. (1967). Conservation Reconsidered. American Economic Review 57, 777-786.

Kutschera, F.v. (1999). Grundlagen der Ethik. 2. Auflage. Berlin, New York: de Gruyter. 
Louviere, J.J., Hensher, D.A. \& Swait, J.D. (2001). Stated Choice Methods - Analysis and Application. Cambridge (UK): Cambridge University Press.

Matthews, M. (ed.) (1998). Constructivism in science education. Dordrecht: Kluwer.

Marggraf, R. \& Streb, S. (1997). Ökonomische Bewertung der natürlichen Umwelt. Theorie, politische Bedeutung, ethische Diskussion. Heidelberg/Berlin: Spektrum Akademischer Verlag.

Mitchell, R.C. \& Carson, R.T. (1989). Using Surveys to Value Public Goods: The Contingent Valuation Method. Washington D.C.: Resources for the Future.

Ott, K. (1996). Grundzüge und -normen einer pragmatischen Wissenschaftsethik. In Ott, K. (Hg.): Vom Handeln zum Begründen (S. 195-240). Tübingen: Attempto.

Pearce, D. (1993). Economic values and the natural world. London: Earthscan.

Rogeberg, O. (2003). Preferences, Rationality and Welfare in Becker's Extended Utility Approach. Rationality and Society 15(3), 283-323.

Rogers, R.W. \& Prentice-Dunn, S. (1997). Protection Motivation Theory. In D.S. Gochman (ed.): Handbook of Health Behavior Research (pp. 113-132). New York: Plenum.

Rozzi, R. (2004). Implicaciones éticas de narrativas yaganes y mapuches sobre las aves de los bosques templados de sudamérica austral. Ornitología Neotropical 15, 435-444.

Sagoff, M. (1998). Aggregation and deliberation in valuing environmental public goods: a look beyond contingent valuation. Ecological Economics 24, 213-230.

Saint-Pierre, C.C.d. (1708). Mémoire sur la réparation des chemins. Paris: Palais Royal. 
Sugden, R. (1999). Alternatives to the Neo-Classical Theory of Choice. In: Bateman, I. \& Willis K.G. (eds.): Valuing Environmental Preferences: Theory and Practice of the Contingent Valuation Method in the US, EU, and Developing Countries (pp. 152-180). Oxford (UK): Oxford University Press.

Turner, K. (1999). The Place of Economic Values in Environmental Valuation. In: Bateman, I. \& Willis K.G. (eds.): Valuing Environmental Preferences: Theory and Practice of the Contingent Valuation Method in the US, EU, and Developing Countries (pp. 17-41). Oxford (UK): Oxford University Press.

U.S. Department of Commerce (1996). National Oceanic and Atmospheric Administration, 61 Federal Register 14261, March 25, 1996. Washington D.C.: US Government Printing Office.

Vosniadou, S. \& Brewer, W.F. (1992). Mental models of the earth: A study of conceptual change in childhood. Cognitive Psychology 24, 535-585.

Weisbrod, B.A. (1964). Collective-Consumption Services of Individual-Consumption Goods. Quarterly Journal of Economics 78, 471-477.

Wilson, M.A. \& Howarth, R.B. (2002). Discourse-based valuation of ecosystem services: establishing fair outcomes through group deliberation. Ecological Economics 41, 431-443.

Zwick, M.M. (2002). Was lässt Risiken akzeptabel erscheinen? Ein empirischer Vergleich von fünf theoretischen Ansätzen. In Zwick, M.M. \& Renn, O. (Hrsg.): Wahrnehmung und Bewertung von Risiken - Ergebnisse des „Risikosurvey Baden-Württemberg 2001“ (S. 35-98). Stuttgart: Akademie für Technikfolgenabschätzung. 


\section{Endnote}

Herzlich Dank sagen möchten wir den Mitgliedern der Arbeitsgruppe für Umwelt- und Ressourcenökonomik in Göttingen, insbesondere K. Glenk, sowie dem Leiter des BIOKONCHILProjekts, K. Jax, für intensive Diskussionen sowie zwei anonymen Gutachtern für hilfreiche Kommentare. Weiterhin danken wir U. Berghöfer für den Einblick in ihre unveröffentlichten Interviewdaten. Forschungen für diesen Beitrag wurden gefördert von BMBF (FKZ 01LM0208) und DFG (SFB 552). 


\title{
CHAPTER III
}

\section{Economic non-market Valuation of Biological Diversity of Navarino island, Patagonia (Chile) in the context of the CBD Ecosystem Approach}

\author{
Claudia Cerda, Jan Barkmann \& Rainer Marggraf
}

\begin{abstract}
The CBD Ecosystem Approach stresses economic as well as participative aspects of conservation management. By applying a choice experiment (CE) both demands are taken into account in this study. The research was carried out on the island of Navarino, Southern Patagonia, Chile. The CE was applied on near random stratified sample of residents $(n=230)$. Ideas of the local population on human-nature relationship were analysed. This input of local values was used to define biodiversity attributes to be analysed with the CE. As most development options for Navarino include some loss of biodiversity, mostly increases in income as levels of the monetary attribute (WTA) were offered. Decisions on future development strategies were influenced by: landscape aesthetics threatened by progressing levels of tourist infrastructure $(\mathrm{P}<0.01)$; nature access restriction due to both economic and conservation concerns $(\mathrm{P}<0.001 ; \mathrm{P}<0.01)$; continued visits of the ethno-culturally important hummingbirds $(\mathrm{P}<0.001)$; protection for an endemic moss $(\mathrm{P}<0.001)$ and ecosystem resilience provided by species diversity (c.f. insurance hypothesis) $(\mathrm{P}<0.001)$. The results indicate that $\mathrm{CE}$ has the advantage of isolation of different biodiversity values effectively as people were able to trade-off biodiversity services against a monetary attribute. Validity was supported by meaningful interactions with Protection Motivation Theory (PMT) attitudinal variables. From a non-market valuation perspective local residents favoured a low impact biodiversity scenario, represented by a tourism development at low scale balanced with the protection of species and the cultural ethnic heritage. Results from stated preference methods as an empowering tool to inform participative decision-making represents an innovative utilisation of economic mainstream methods for furthering the aims of the Ecosystem Approach.
\end{abstract}




\section{Introduction: The Ecosystem Approach of the CBD - economic perspective and partici- pation}

The Convention on Biological Diversity (CBD) establishes the importance of the economic context in which conservation activities take place (UNEP 1992). Almost all of its objectives and articles require the understanding and use of economics for their implementation (IUCN 2000). Perhaps most importantly, economics is crucial to biodiversity conservation because unless it makes demonstrable economic and financial sense for people to conserve biodiversity, it is unlikely that individuals, households, industries, companies or governments will take action to do so (IUCN 2000). However, the market mechanism does not intrinsically take account of the negative as well as of the positive "externalities" of biodiversity uses (Mishan 1971, Marggraf \& Streb 1997). There is widespread consensus that, in general, the market mechanism undervalues the natural systems and their biological diversity (McNeely 1988). One of the major economic obstacles to conservation of biodiversity is that biological resources are often not given appropriate prices in the marketplace (McNeely 1988). The task, therefore, is to develop methods that assess economic values of biological diversity. This aspect may constitute a decisive criterion for political decisions of conserving biological diversity (Roth 2005, Bateman et al. 2002).

On the other hand, understanding that a sustainable use of biological diversity can only yield fruit if as many interests as possible are taken into account, the CBD also addresses the inclusion of social and cultural aspects. But how can the sustainable use of biological diversity be achieved? The so-called CBD Ecosystem Approach (EA) provides the guidelines of this research. The CBD Ecosystem Approach is a strategy for the integrated management of land, water and living resources that promotes conservation and sustainable use in an equitable way (UNEP 1992). The Seville strategy for UNESCO Biosphere Reserves calls for an application of the Ecosystem Approach. In the CBD Ecosystem Approach, the inclusion of values of people into biodiversity management are strongly emphasized. The importance of the economic context of conservation as well as local participation in conservation management are stressed. Accounting for these demands, the questions: Which are the economic preferences of people for biodiversity services? and, What economic meaning do determined aspects of biological diversity have for people? arise to be addressed in the widest sense. 
Attempting to respond these questions, different methodologies for assessing economic values of biodiversity have been developed and applied. Where are no markets at all associated with the good to be valued, Stated Preference Techniques (SPT) permit to elicit economic valuations. The Contingent Valuation (CV) and Choice Experiment (CE) methods are known for this purpose. $\mathrm{CV}$ remains the most commonly applied stated preference technique in this area, having almost two thousand studies in the literature (Carson et al. 2003). The values are elicited through some form of questionnaire approach (Pearce \& Barbier 2000: 62). ${ }^{1}$

This research explores the potential of a standard SPT, a CE on the island of Navarino, Southern Patagonia, Chile, to account for the demands of the CBD Ecosystem Approach. The study aims at an improved implementation of the CBD Ecosystem Approach by an assessment of sustainable development options for Navarino island that are based on improved economic instruments for the assessment of non-use and indirect-use benefits from the biological diversity of the island. This required a detailed illustration of local residents preferences for biodiversity services by enhancing the ability of stated preference techniques to assess indirect and non use-biodiversity related benefits (Barkmann et al. 2005, Barkmann et al. 2006).

It was decided to explore the potential of the "normal" $\mathrm{CE}$ conducted with individual respondents instead of a Contingent Valuation $(\mathrm{CV})^{2}$. Several reasons justify this decision: a) the biological conservation on Navarino is necessarily related to decisions of management and politic which are often mainly concerned with changes in the levels that the attributes of biodiversity could take more than the biodiversity as a whole. Thus, CE allows for the concurrent economic estimation of several facets of biodiversity, over a range of quantities/qualities. This makes the method - in theory - more versatile and more applicable for early planning processes. The situation on

\footnotetext{
${ }^{1}$ Stated Preference Techniques have been criticized by many authors, however. A summary of the main criticisms is briefly presented, as we can not discuss them in detail here: a) Responses to SPT questions concerning environmental preservation may be dominated by citizens judgments concerning social goals and responsibilities rather than by consumer preferences (see Sagoff 1988, 1996), b) CV responses reflect the willingness to pay for the moral satisfaction of contributing to public goods, not the economic value of these goods (Kahneman \& Knetsch 1992: 57), c) CV is a deeply flawed methodology for measuring non-use values. The absence of direct market affects both the ability to judge the quality of contingent valuation responses and the ability to calibrate responses to have usable numbers (Diamond \& Hausman 1994: 62), d) The empirically observed differences between WTP and WTA are substantially bigger than implied by micro-economic standard theory (Sugden 2005).

${ }^{2}$ In fact, in CV applications, concerns regarding the validity of results have been expressed as a result of (among others): strategic bias, yea-saying, insensitivity to scope variations and framing (see Bennett \& Blamey 2001). Besides, questions such as "What are you willing to pay?" are thought by some critics of CV to present cognitive problems (Bateman et al. 2002: 74).
} 
Navarino island turned out to be of this type, b) CE can avoid some of the problems with protest responses since people may find it easier to rank or rate alternatives without having to think in money terms directly, because the economic value can be derived through the device of including a money indicator (a price, charge or tax) (Pearce \& Özdemiroglu 2002), c) CE can isolate different biodiversity values categories as the different value components can be included directly in the trade-off process. The respondents are confronted with realistic, multi-dimensional trade-offs that mimic many real-life decision-making processes (c.f. Pearce \& Özdemiroglu 2002).

In section 2, the case study on sustainable development options for Navarino island is presented. The study uses a choice experiment approach for the valuation of biodiversity-related values. The results are provided in section 3. In section 4 the study and its results are discussed, and finally it is attempted to draw some conclusions.

\section{Methods}

\subsection{Study area}

The island of Navarino is located at the extreme south of America, north of the Cape Horn Archipelago (Fig. 1). This region is one of few not fragmented and only slightly transformed temperate forests of the world (dominant species: Nothofagus pumilio, Nothofagus antarctica) (c.f. Rozzi 2003, Rozzi et al. 2004). The island is characterized by high habitat diversity and diversity of species groups such as mosses and lichens (Sherriffs et al. 2004, Rozzi et al. 2004). The local NGO Omora Foundation, has incentived active environmental education projects. One focus of these projects are mosses and lichens (c.f. Sherrifs et al. 2004). Also cultural diversity is high. Cultural diversity includes the last surviving representatives of the island's original indigenous, the Yaghans.

The population is concentrated in the Puerto Williams town. The about 2,000 citizens are mainly employed by the Chilean Navy, public administration and the fishing industry (Cerda et al. 2005). Because of the remote location, Navarino can only be accessed regularly by air and a weekly ferry. Right now, the island is only little dissected by infrastructure (Fig. 1); the ecological impact of agricultural and tourist activities is low. This because up until the end of 1990s access to the 
island was severely restricted due to military reasons (Jax 2005). Currently, there exists a renewed interest in development of tourism and salmon farming which could significantly influence ecosystem function and species composition in the southernmost region of the Americas. In 2005, Navarino island and the two adjacent national parks were declared UNESCO Biosphere Reserve (c.f. Rozzi et al. 2004). The Biosphere Reserve aims to harmonize conservation and use of biological diversity and to provide and adequate frame for the planning and implementation of sustainable development on the island (Rozzi et al. 2004). Thus, Navarino island represents a good example for an application of conservation strategies in line with the CBD.

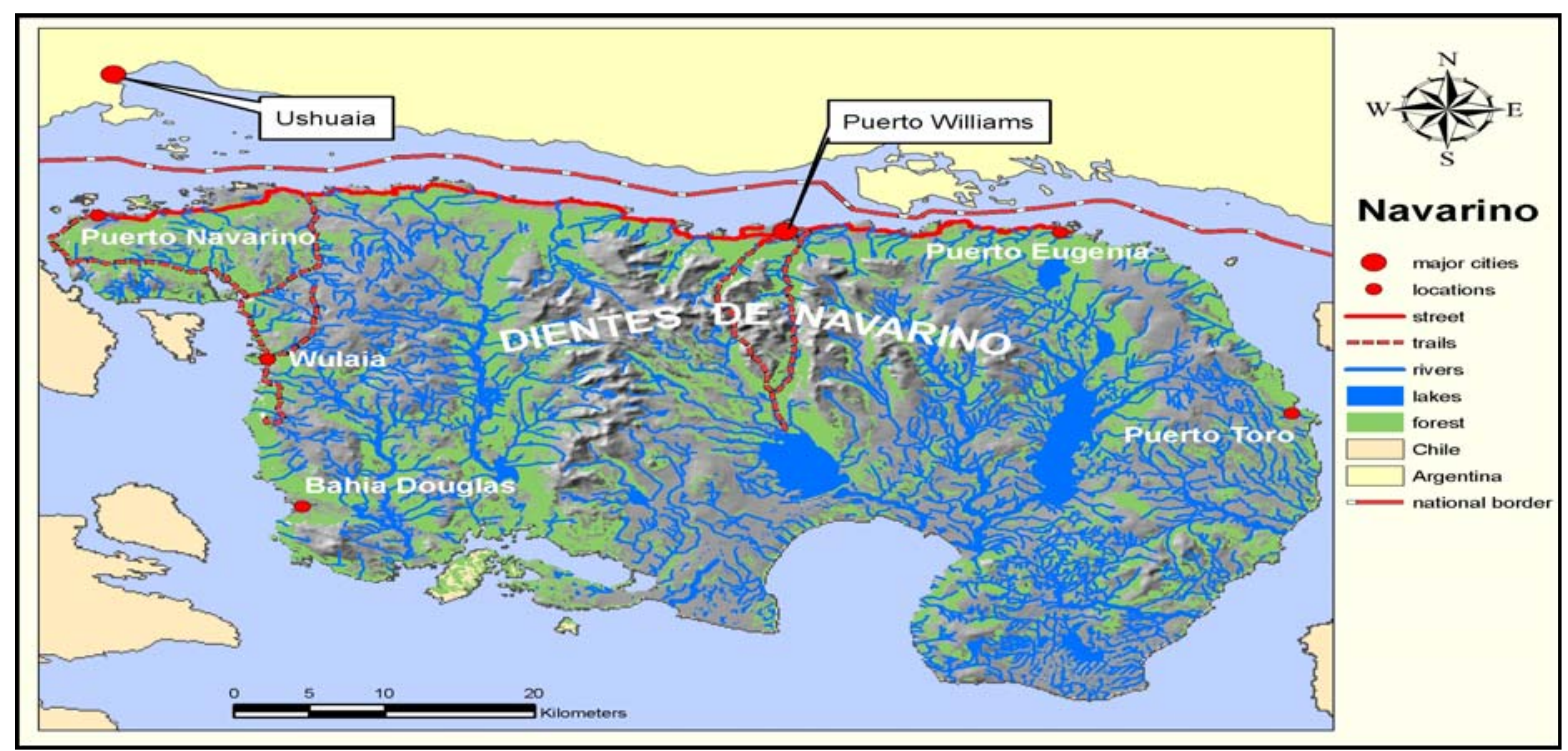

Fig. 1. Navarino island location. Source: Jax et al. (2007).

\section{2 The choice experiment approach: brief introduction to the method}

Choice experiments were developed originally in the marketing and transport literature by Louviere \& Hensher (1982) and Louviere \& Woodworth (1983). More recently it has been applied in the environmental context by Boxall et al. (1996), Adamovicz et al. (1998), Hanley et al. (1998), Blamey et al. (2000), Rolfe et al. (2000), Horne \& Petäjistö (2003), Othman et al. (2004), Colombo et al. (2005), Mogas et al. (2005), Naidoo \& Adamowicz (2005). The Random Utility Theory (RUT) (c.f. Thurstone 1927, McFadden 1973, Manski 1977) pro- 
vides the theoretical basis for integrating choice behaviour with economic valuation. Under RUT, the utility of a good is decomposed into an observable component which is a function of a vector of attributes and respondent characteristics, and an unobservable error component. The respondents are presented with a series of choice sets, each containing usually three or more resource use options. From each choice set, respondents are asked to choose their preferred option. By repeating such choices among options with varying attribute levels, the researcher can infer pieces of information: Which attributes significantly influence choice and the implicit ranking of these attributes. If one attribute is cost, the marginal WTP/WTA for an increase in any significant attribute can be calculated (Hanley et al. 1998).

Given certain assumptions on the distribution of the error term, the probability of any particular option being chosen can be expressed in terms of logistic distribution (McFadden 1973). The standard Multinomial Logit Model (MNL) applies under these assumptions. If MNL fulfils with the Independence of Irrelevant Alternatives condition (IIA) (see Train 2003, Hensher et al. 2005), then it can be used to predict choice behaviour as a function of the attributes and levels that identify different sets of alternatives (c.f. Hensher et al. 2005). The IIA property states that the ratio of the choice probabilities of any pair of alternatives is independent of the presence or absence of any other alternative in a choice set. This implicates that all pairs of alternatives are equally similar or dissimilar (Hensher et al. 2005: 479). The MNL model can be estimated by maximum likelihood techniques (c.f. Hensher et al. 2005, Louviere et al. 2000). When MNL does not satisfy the IIA condition, Nested Logit Models (NLM) can be used to overcome such a limitation (see Hensher et al. 2005). Nested Logit is a choice method specifically designed to recognize the possibility of different variances across the alternatives and some correlation among sub-sets of alternatives. The presence of these possibilities is equivalent to relaxing IIA to some extent (Hensher et al. 2005: 482). 


\subsection{Attitudinal variables}

The economic valuation of biodiversity requires a multidisciplinary approach. Usually, economists have to draw upon the theoretical knowledge of psychology and other disciplines (Green \& Tunstall 1999). The inclusion of attitude-behavioural models that link attitudes and intended behaviour as revealed by surveys, are standard practice in the application of stated preference methods (i) to explain individual preference variations, and (ii) to relate preferences to underlying respondent values in order to support the validity of results generated from - hypothetical - stated preference surveys (Bateman et al. 2002: 113, Arrow et al. 1993).

The Protection Motivation Theory (PMT) (c.f. Rogers \& Prentice-Dunn 1997) appeared as a suitable way to fulfill with these requirements. The PMT belongs to the rational choice approaches in social psychology and is one formulation of the effects that threatening incidents can have on attitude and behavior change (Rogers \& Prentice-Dunn 1997). The main objective of the PMT is the explanation of intentions and behavior changes to prevent threatening events. The theory was proposed in the context of personal health threats and it appears to have broad applicability, including to natural and technological hazards and to environment threats (Gardner \& Stern 1996). A main feature of the theory is that it differentiates two major perceptual/cognitive processes that together determine an individual's response to a threat: threat appraisal, which assesses the nature and magnitude of a threat, and coping appraisal which assesses the type and amount of coping responses the individual has available (Rogers \& Prentice-Dunn 1997). We briefly mention here the PMT components of each process.

The threat appraisal process has three components (Rogers \& Prentice-Dunn 1997):

Relevant values: A person sees that a feature of his/her environment is a risk if he/she believes that the feature endangers something that he/she values.

Severity of a threat: It is the person's appraisal of how damaging the outcome of the threat would be to things he/she values if the threat were actually to occur.

Perceived vulnerability: It is the person's perception of the probability or likelihood of the threatening event's actually occurring.

The coping appraisal process has three components (Rogers \& Prentice-Dunn 1997): 
Self efficacy: is the person's assessment of whether he/she is personally capable of performing the requisite of protective acts.

Response efficacy: it means whether the person knows of any specific actions that he/she believes are effective against the threat.

Costs and benefits: This includes many of the barriers that impede people from acting on their pro-environmental attitudes and values.

An early empirical application in a stated preference survey is found in Menzel (2003). By using a CV valuation survey, Menzel investigated the influence of the PMT variables on the "acceptance of payment".

In the study here presented, it was hypothesized that the PMT variables explain monetary valuation obtained with the CE approach. Table 2 in section 2.4.4, shows the PMT variables used for the main CE application and their operationalization.

\subsection{The design of the study}

Our study involved several steps which are presented as follows.

\subsubsection{Development of attributes and choice cards}

As suggested by the CBD Ecosystem Approach, identification of local relevant sources of biodiversity benefits is required for biodiversity management. In order to achieve an effective isolation of single categories of biodiversity benefits, we focussed on the "Total Economic Value" (TEV) concept (Pearce 1993, Pearce \& Moran 1994), as an a priori point of reference in classifying indirect and existence economic benefits of biological diversity. An effective isolation also attempts to avoid embedding effects which can be particularly severe for existence values (see Cerda et al. 2006). Based on the background obtained from the first visit to Navarino in September 2003, experts consultations, and literature revision related to Navarino's biodiversity, a list of preliminary biodiversity benefits categories was developed from October to December 2003. This list included: aesthetic biodiversity benefits at landscape and species levels, the "existence" benefits of the continued existence of inconspicuous species and the functional biodiversity benefits related to water supply. Related to the existence of the indigenous community "Yaghan", ethno- 
symbolic biodiversity benefits were also considered as a category.

In order to identify pre-theoretic cognitions (“images") (c.f. Barkmann et al. 2005) of the mentioned categories, and additional biodiversity services that are relevant for the residents of Navarino, semi-structured questionnaires were used in collaboration with other BIOKONCHIL researchers. The exploration of these images offers, from an environmental economic point of view, an alternative to the identification of significative valuation dimensions for biodiversity and a contribution to the interpretation and corroboration of the results. 54 interviews were conducted with local residents. 14 were immediately transcripted and analysed. Results of the 14 interviews were cross-checked with field notes and tape recordings of the other 40 interviews (c.f. Berghöfer 2005). From this analysis, the following valuation dimensions were identified:

- Aesthetic value at landscape level: leisure and aesthetic functions of landscape were regarded as more important than water services. Additionally, the tourist infrastructure necessities were a clear mentioned topic as well. Respondents were generally supportive of some additional tourist infrastructure as long as it would not affect the aesthetic qualities of the landscape.

- Access to nature: Spontaneously, the free access to nature for enjoying the landscape was very frequently mentioned by most respondents as an important amenity of the island. It called to include this additional category of benefit.

- Aesthetic value at species level: Respondents referred to the Carpintero (woodpecker; Campephilus magellanicus), the cóndor (Vultur gryphus) and the guanaco (Lama guanicoe) as the best known and most liked native species.

- Ethno-symbolic value: The interviewed residents knew very little with respect to the biological and symbolic "resources" of the Yaghan culture. No one mentioned to know biological symbols for this culture. Two respondents mentioned the archaeological places as important.

- Inconspicuous species existence value: No respondent mentioned any inconspicuous species as known or preferred plant. All respondents expressed to know of the existence of mosses on the 
island when directly asked, however. It reflected that the respondents only have a very general notion about the existence of these species on the island. Therefore, with respect to a moss species, any benefit expressed in a stated preference survey was to be largely expected as an expression of an existence value for that species.

Based on the input from the qualitative phase of the study and the corresponding "images of nature" analysis, the attributes that defined each choice were the following:

a) Change on landscape by impact of tourist infrastructure: the link between aesthetic services of landscape and the likely tourist infrastructure, prompted us to include both aspects in one attribute. The changes on landscape were represented by levels of infrastructure operationalized by numbers and types of cabins/hotels and trails/roads (see Fig. 2). The Status Quo level was defined as very low change because very basic tourist infrastructure has been built on the island leading to a minimum change on landscape. It is likely that additional infrastructure will be built because several analysis have shown a great potential for tourism development in Southern Patagonia including the island of Navarino (see e.g., Voss 2005).

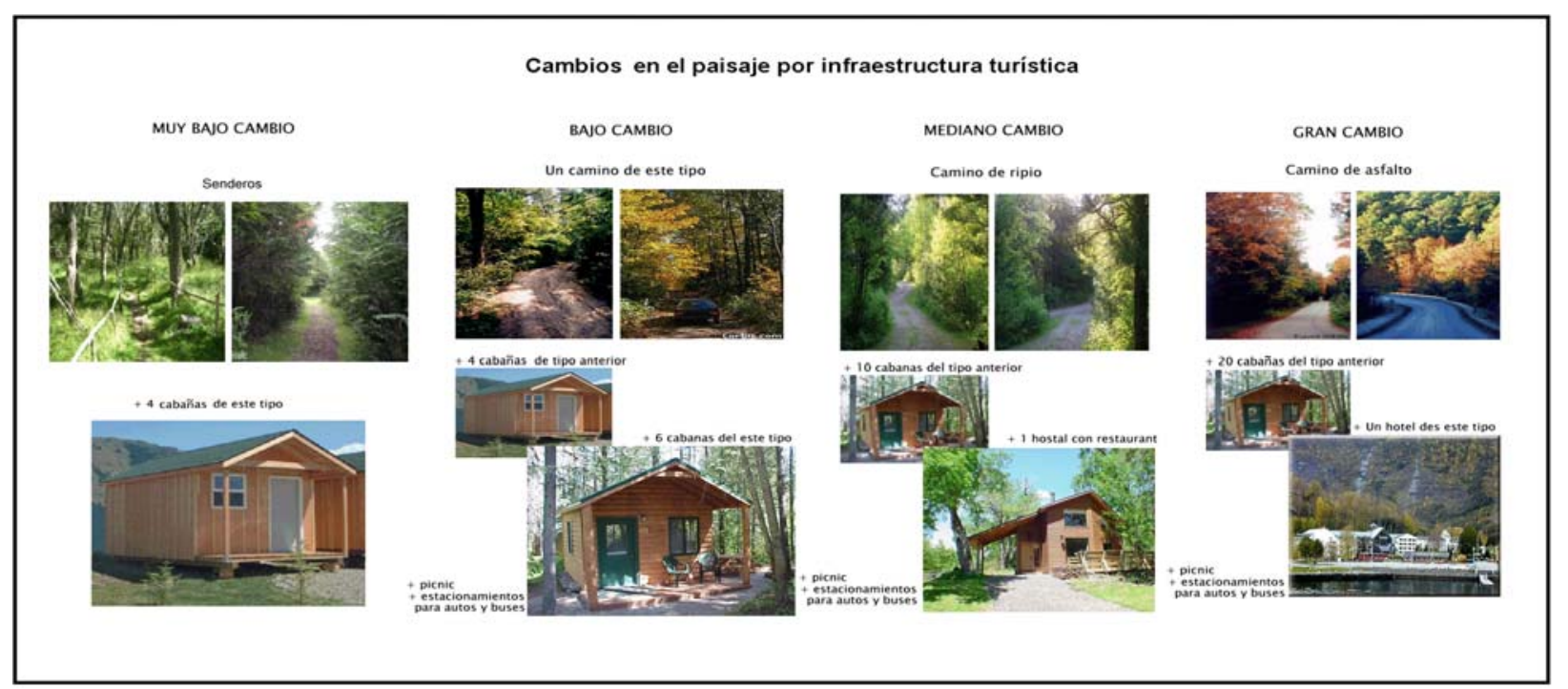

Fig. 2. Levels of change on landscape by impact of tourist infrastructure used to explain the attribute during the main application of the choice experiment questionnaire. 
b) Access to nature for private and conservation interests: Three levels of restrictions of access to the landscape of Navarino were defined. The Status Quo level was defined as not restricted. For the restriction levels most of the West and the South of the island was closed off. Access restrictions are in fact quite likely as concessions of several thousand hectares in size at the West coast of Navarino were granted recently for hotel enterprises by the Chilean Land Use Ministry. Most landscape and nature related recreational activities of the residents take place at the "unrestricted" North coast, however. On the other hand, the future local regulation for the land issue of Navarino (Seccional Plan) establishes a zoning based on conservation goals as well as economic development. For example, the north coast which is the most accessible, was only reserved for investments at high scale.

We used a split sample either focusing on private and conservation reasons of restrictions, to test for differences in preferences depending on the purpose of the restriction. Figures 3(a)/(b) show maps of the island used to present the levels of restrictions to the respondents. The same maps were used to explain access restrictions to nature for private and conservation concerns.

Fig. 3a. Medium restricted access.

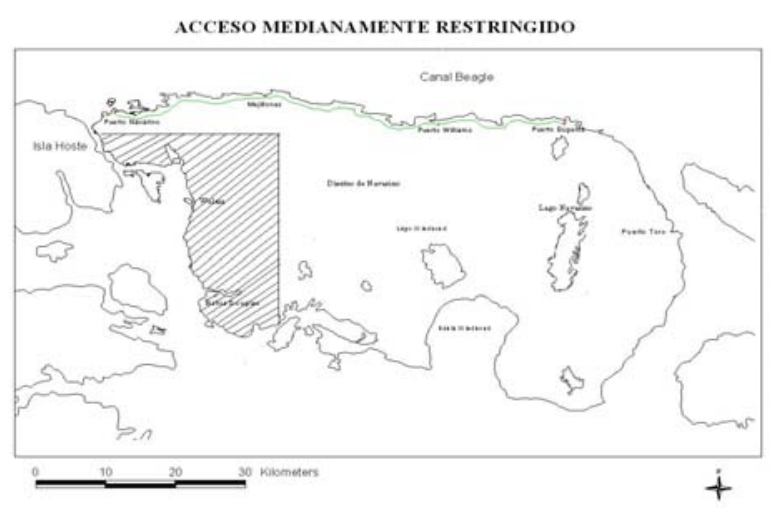

Fig. 3b. Highly restricted access.

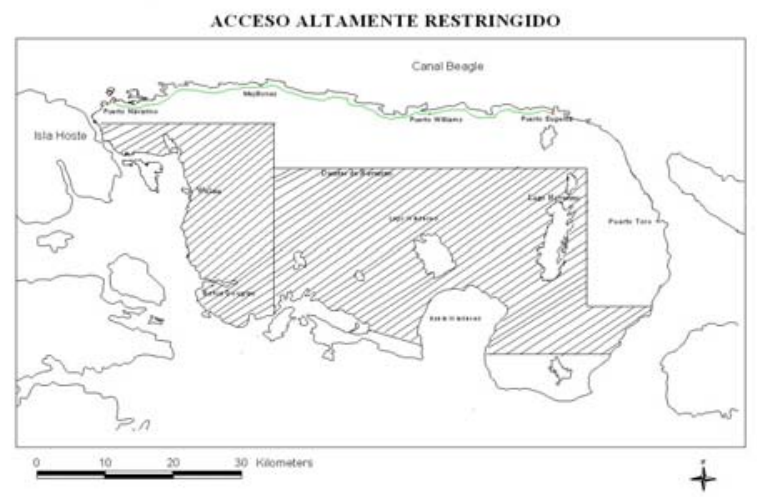

Figs. 3(a)/(b). Maps of Navarino island used to explain the levels of medium and highly restricted access. Painted areas indicate location of restrictions.

Source: Map: Jax et al. (2005); Representation of restrictions: own elaboration.

c) Possibility to see carpinteros, guanacos and cóndores: The attribute varied in two levels with respect to the base one (see them as often as now). The levels were related to the number of times that these birds can be seen by the residents in one year. A change on providing the aesthetic ser- 
vices of these animals is realistic as current activities related to the forest issue and a predicted increasing of tourism could affect their habitats.

d) The hummingbirds visit Navarino: Although our qualitative interviews revealed a poor knowledge of the inhabitants with respect to biodiversity Yagan symbols, we decided to include the "visit of the hummingbirds" as an attribute. Two aspects justify this decision: a) these birds are admired by the Yagan culture. The hummingbird plays a very important role in old Yaghan histories in which it is perceived as a small spirit maintaining the harmony between nature and humans (Rozzi 2003). b) The Yaghan culture is actually close to extinction. It is an important goal of local decision makers to rescue the culture.

The hummingbirds are occasional visitants on the island. Their habitat on Navarino is provided by "notro" (Embothrium coccineum) thickets (c.f. Rozzi 2003). This habitat is susceptible to be damaged by different economic development activities.

e) Probability of extinction of an endemic moss: The CBD Ecosystem Approach suggests the inclusion of multiple values into biodiversity management. As revealed by the qualitative interviews, the attention and knowledge of most inhabitants of Navarino are focused on a very small number of species and ecosystem services. On the other hand, it is a specific challenge to assess the existence value of species that can be found in the same "habitats" that the respondents. If people know these species, they may also value them for some use or indirect use benefits (Cerda et al. 2006). Because of the importance of the moss flora of Navarino, a moss species endemic to the subanctarctic forests was chosen.

No moss species is known that is strictly endemic to Navarino island. The forests of Navarino constitute a substantial portion of the habitat for mosses endemic to the Magellanic subantarctic forests, however. Large scale economic development projects on forest operations on Navarino can affect a fraction of the entire habitat of an endemic moss, and result in an increased extinction risk. Thus the attribute varied in three levels of probability of extinction. The status quo level corresponded to low probability of extinction as this moss can be found in several places of the subanctarctic zone, including its spaces on Navarino. 
f) Indirect insurance benefits: This issue did not show up spontaneously in the qualitative interviews. The topic was regarded as a suitable way to introduce a systemic and long-term perspective into the valuation exercise, however. These economic insurance benefits correspond to benefits from the ecological insurance hypothesis on the effect of species diversity on the stabilization of ecosystem processes (c.f. Yachi \& Loreau 1999).

The specific way to address these insurance benefits follows functional descriptions of ecosystem health, in which the vigor and resilience of ecological systems are stressed (Costanza et al. 1992). For further details see, e.g., Kutsch et al. (2001), Barkmann et al. (2001), Barkmann \& Marggraf (2004). As the ecological "insurance hypothesis" is formulated in relation to species richness, the attribute was called: Number of types of animals and plants that indicates health, resistance and vigour of nature. The levels were operationalized by using number of species present on the island. For example, if an extreme development scenario results in the likely long-term loss of a quarter or of one half of the species on the island, this was assumed to result in substantial losses of ecosystem health.

g) Monthly income change: For use in public policy on the island of Navarino, Willingness to Accept (WTA) appeared as more appropriated and not Willingness to Pay (WTP). The WTA issue has advantages: a) for value estimations at species levels, a "warm glow of giving" effect (Kahneman \& Knetsch 1992) was avoided because the CE did not imply a voluntary contribution to the protection of species and b) the results do not reflect ability to pay. From a participative aspect this is important as the impact of respondent wealth on expressions of preferences was expected to be low. It was used a change in income mainly operationalised via increases in income as many realistic choice options imply a deterioration of the ecological status quo. We included three increases in income - i.e. the willingness-to-accept compensation (WTA) versus one decrease in income because some combinations resulted in biodiversity improvements.

\subsubsection{Pilot study}

A pilot study of choice experiment $(n=45)$ was carried out during April and May 2004. A WTA exclusive format was used. All biodiversity attributes worked well and were kept in the main study. All showed or at least strongly promised statistic significance. There were zero protest 
responses during the application of the pilot questionnaire. This preliminary CE implementation revealed empirical evidence for the influence of PMT constructs on the probability to choose one of the proposed options. As some combinations of attribute levels resulted in an ecologically improved situation, we introduced also a level with a negative income change for the main study (see Tab. 1).

\subsubsection{Attributes and levels used for the main CE study}

The attributes and levels used for the main CE application are specified in Table 1.

Tab. 1: Attributes and levels used for the main choice experiment application.

\begin{tabular}{|c|c|c|}
\hline $\begin{array}{l}\text { Valuation } \\
\text { dimension }\end{array}$ & Attribute & $\begin{array}{l}\text { Levels } \\
\text { (coding) }\end{array}$ \\
\hline $\begin{array}{l}\text { Aesthetic } \\
\text { quality of } \\
\text { landscape }\end{array}$ & $\begin{array}{l}\text { Change on landscape by impact of } \\
\text { tourist infrastructure }\end{array}$ & $\begin{array}{l}\text { Very small change }(-1)^{*} \\
\text { Small change }(+1) \\
\text { Medium change }(+1) \\
\text { Big change }(-2) \\
\text { (For illustration of levels see Fig. } 2) \\
\end{array}$ \\
\hline $\operatorname{Access}^{\S}$ & $\begin{array}{l}\text { Access restrictions to nature for } \\
\text { private interests } \\
\text { Access restrictions to nature for } \\
\text { conservation interests }\end{array}$ & $\begin{array}{l}\text { Not restricted }(1)^{*} \\
\text { Medium restrictions (2) } \\
\text { Very restricted (3) } \\
\text { (For illustration of levels see Figs. 3(a)/(b)) }\end{array}$ \\
\hline $\begin{array}{l}\text { Aesthetic } \\
\text { value }\end{array}$ & $\begin{array}{l}\text { Possibility to see animals } \\
\text { (carpinteros, guanacos, cóndores) }\end{array}$ & $\begin{array}{l}25 \% \text { more than now }(1) \\
\text { as now }(2)^{*} \\
25 \% \text { less than now }(-2)\end{array}$ \\
\hline $\begin{array}{l}\text { Ethno } \\
\text { symbolic } \\
\text { value }\end{array}$ & The hummingbirds visit Navarino & $\begin{array}{l}\text { They do not come to the island anymore }(-1) \\
\text { Not secure visit }(0)^{*} \\
\text { Secure visit }(+1)\end{array}$ \\
\hline $\begin{array}{l}\text { Existence } \\
\text { value }\end{array}$ & $\begin{array}{l}\text { Probability of extinction of an en- } \\
\text { demic moss }\end{array}$ & $\begin{array}{l}\text { Increased probability }(-1) \\
\text { Low probability }(+1)^{*} \\
\text { Very low probability }(+1)\end{array}$ \\
\hline $\begin{array}{l}\text { Ecosystem } \\
\text { "health" }\end{array}$ & $\begin{array}{l}\text { Number of types of animals and } \\
\text { plants indicating "health, resistance } \\
\text { and vigour of nature" }\end{array}$ & $\begin{array}{l}400 \text { types ("low health, vigour and resistance") } \\
800 \text { types ("medium...") } \\
1,600 \text { types ("high ...")* }\end{array}$ \\
\hline $\begin{array}{l}\text { Payment } \\
\text { vehicle }\end{array}$ & Monthly income change & $\begin{array}{l}\text { - } \$ 30.000 \text { Chilean pesos } \$ \\
\quad \$ 0 \text { Chilean pesos* } \\
+\$ 20.000 \text { Chilean pesos } \\
+\$ 30.000 \text { Chilean pesos } \\
+\$ 40.000 \text { Chilean pesos }\end{array}$ \\
\hline
\end{tabular}

* Status Quo level; ${ }^{\S}$ a split sample differentiating access restrictions for private and conservation concerns; ${ }^{\$} 100 \mathrm{CHP} \sim 0.13$ Euro at the time of the main study. 
Orthogonal main effects design procedures to generate reduced orthogonal experimental design were calculated (see Louviere \& Woodworth 1983, Louviere et al. 2000, Louviere 2001). 32 profiles were obtained and combined into choice scenarios with two options A and B and one Status Quo which conformed each set of choices (c.f. Hanley et al. 2001, Bennett \& Blamey 2001). The profiles were divided in four blocks of 8 choices each. These blocks were randomly assigned to the respondents. Figure 4 shows an example of choice sets used for the main CE application.

What option do you prefer?

\begin{tabular}{|c|c|c|c|}
\hline Attributes & Option A & Option B & Status Quo \\
\hline $\begin{array}{l}\text { Change on landscape by impact } \\
\text { of tourist infrastructure }\end{array}$ & Small change & Big change & Very small change \\
\hline Income change/month & \$0/month & $+\$ 30.000 /$ month & $\$ 0 /$ month \\
\hline $\begin{array}{l}\text { Number of types of animals } \\
\text { and plants }\end{array}$ & $\begin{array}{l}1,600: \text { High health, } \\
\text { resistance and vigour } \\
\text { of nature }\end{array}$ & $\begin{array}{l}800 \text { : Medium health, } \\
\text { resistance and vigour } \\
\text { of nature }\end{array}$ & $\begin{array}{l}1,600 \text { : High health, } \\
\text { resistance and vigour } \\
\text { of nature }\end{array}$ \\
\hline $\begin{array}{l}\text { Possibility to see carpinteros, } \\
\text { guanacos and cóndores }\end{array}$ & As now & $\begin{array}{l}25 \% \text { more often than } \\
\text { now }\end{array}$ & As now \\
\hline $\begin{array}{l}\text { Probability of extinction of an } \\
\text { endemic moss }\end{array}$ & Increased & It is very low & It is low \\
\hline $\begin{array}{l}\text { Access restrictions to nature } \\
\text { (for private or conservation con- } \\
\text { cerns) }\end{array}$ & Medium restrictions & Very restricted & No restrictions \\
\hline $\begin{array}{l}\text { The hummingbirds visit } \\
\text { Navarino }\end{array}$ & $\begin{array}{l}\text { They do not come to } \\
\text { the island anymore }\end{array}$ & Not secure visit & Not secure visit \\
\hline I choose option : & $\mathbf{X}$ & & \\
\hline
\end{tabular}

Fig. 4. Example of one of the eight choice sets presented to the respondents in the choice experiment (translation from Spanish). 


\subsubsection{Application of the PMT for the main CE application}

The main CE application required to select those PMT sets of items of the pilot study, that performed well in reliability analysis (c.f. Bühl \& Zöfel 2000). 4-point Likert scales from 1 ( $I$ strongly disagree) to 4 (I strongly agree) were used for each item included in the main study. Tab. 2 shows the PMT variables operationalized for each attribute used in the main study.

Tab. 2. Operationalization of the PMT variables used in the main CE application.

\begin{tabular}{|c|c|c|}
\hline $\begin{array}{l}\text { Matching } \\
\text { attribute }\end{array}$ & $\begin{array}{l}\text { PMT } \\
\text { variable } \\
\text { (see section 2.3) } \\
\end{array}$ & Operationalization \\
\hline \multirow{2}{*}{$\begin{array}{l}\text { Change on landscape by } \\
\text { impact of tourist } \\
\text { infrastructure }\end{array}$} & Value & $\begin{array}{l}\text { To keep the actual landscape on the island is very } \\
\text { important to me. }\end{array}$ \\
\hline & Likelihood & $\begin{array}{l}\text { It is not very likely that strong changes will occur on the } \\
\text { island. }\end{array}$ \\
\hline Access restrictions to nature & Value & $\begin{array}{l}\text { To access most places on the island freely, is very } \\
\text { important to me. }\end{array}$ \\
\hline Possibility to see animals & Value & $\begin{array}{l}\text { To have the possibility to see animals is very important to } \\
\text { me. }\end{array}$ \\
\hline $\begin{array}{l}\text { The hummingbirds visit the } \\
\text { island }\end{array}$ & Self-efficacy & $\begin{array}{l}\text { I can do something for the continued visits of the } \\
\text { hummingbirds. }\end{array}$ \\
\hline \multirow{2}{*}{$\begin{array}{l}\text { Probability of extinction of } \\
\text { an endemic moss }\end{array}$} & Value & $\begin{array}{l}\text { The existence of an endemic moss is very important to } \\
\text { me. }\end{array}$ \\
\hline & Severity & $\begin{array}{l}\text { If the endemic moss disappears, it is a big problem for } \\
\text { nature. }\end{array}$ \\
\hline \multirow{2}{*}{$\begin{array}{l}\text { Number of type of animals } \\
\text { and plants }\end{array}$} & Value & $\begin{array}{l}\text { To keep the health, resistance and vigour of nature is not } \\
\text { of interest to me. }\end{array}$ \\
\hline & Severity & $\begin{array}{l}\text { A decrease in the number of type of animals and plants } \\
\text { could have disastrous effects for the island. }\end{array}$ \\
\hline
\end{tabular}

\subsubsection{The questionnaire}

A "pro-conservation" subtext in the survey instrument was carefully avoided. An introductory section in the interview explained the objective of the study to obtain the opinion of local residents respect to different changes on landscape and nature of the place. It was clearly explained that the information will be delivered to local decision makers.

The second phase consisted of an exhaustive explanation of each attribute and levels. To avoid fatigue and confusion and to reduce cognitive demand, visual material such as photographs and maps of the island (see Figs. 2 and 3(a)/(b)) as well as photographs of several species involved in the study were used. Further qualitative questions related to each attribute being valued were also 
included (see Appendix 1; CE questionnaire).

The choice sets were presented to the respondents in a third phase of the interview. Each respondent was asked to complete the choice experiment section by selecting eight times one of the three available options (see Fig. 4). The two last parts contained PMT items and some sociodemographic questions, including household income.

\subsection{Administration of the survey}

The main survey was carried out face to face by the first author of this paper, and two well trained Chilean university students from January to April 2005. To carry out a stratified sample of the residents of Navarino island, the different economic activities as used by the Chilean National Census (INE 2002) were employed as stratification criteria. The research focused on the permanent ${ }^{3}$ population of Navarino (see Tab. 4 in section 3.1) with more than 15 years old $(\mathrm{N}=1328)$. As students $(\mathrm{N}=67$; non economically active group) do not perceive direct income, they were excluded from the sampling frame.

\subsection{Model estimation}

For the attributes change on landscape by tourist infrastructure and possibility to see animals, preliminary analysis revealed a non-linear utility function. In both cases, statistical performance of models with dummy-coded attribute levels (see Hensher et al. 2005: 119) indicated an inverted U-shaped utility function. The coding was adjusted accordingly, and used for model construction (see Tab. 1). For the case of the moss existence attribute, the dummy-coded attribute levels analysis, indicated no big differences in utility between the current and best levels of moss protection. The coding was also adjusted (see Tab. 1) and used for model estimation.

The choice models of data were generated by statistical routines using the software package LIMDEP/NLogit 3.0. Because violations of the IIA condition were observed for several multinomial logit models generated from the data $\operatorname{set}^{4}$, Nested Logit (NL) procedures, that partly relax

\footnotetext{
${ }^{3} \sim 240$ people from Punta Arenas city are classified by the National Census as part of Navarino island's population. The Census classifies this group as belonging to the fishing activity on the island. They are employed by the fishing enterprises located on Navarino, and are present on the island only for the king-crab extraction period. Because of their non-permanent population condition, they were excluded from the sampling frame.

${ }^{4}$ A Hausmann test (Hausmann \& McFadden 1984) was performed for the MNL model to test the assumption of the independence from irrelevant alternatives (IIA). To carry out the test, the MNL model was re-estimated on a subset of the alternatives.
} 
IIA assumption (see Hensher et al. 2005) were applied. The Inclusive Value of the degenerated branch was set to 1.0 (Hensher et al. 2005: 570). Scale parameters were normalized at the lowest level, (RU1; Hensher et al. 2005: 538). The best fitting tree structure with an Inclusive Value (IV) between zero and 1 was selected (Hensher et al. 2005: 494). A weighting factor for each respondent observation, was included to take account of stratification sampling bias (see Tab. 4 in section 3.1). An alternative specific constant (ASC) was also included, taking the value of 1 for the scenarios A and B, and 0 for the Status Quo option. The ASC was constrained to be equal for the alternatives $\mathrm{A}$ and $\mathrm{B}$ because a generic format was used to develop the choice sets. Socioeconomic and PMT attitudinal variables were incorporated into model. As the socio-economic and PMT variables can not be introduced alone into modelling because respondent characteristics do not vary across alternatives, they had to be introduced as interactions with the ASC or the attributes (Bennett \& Blamey 2001: 60, Bateman et al. 2002: 283). Socio-economic variables were included by interactions with the ASC. Seven socio-economic variables were tested (age, sex, income, respondent has children, years of education, time on the island, expected future time to live on the island) and, accordingly, included in the final models when influence on choice was detected. The PMT items (Tab. 2) were included by interactions with attributes. Testing of interactions related to the 9 PMT items, was restricted to matching attributes. Interactions were deleted when no significance was found. To avoid collinearity between the PMT interaction variables and the matching attribute, two identically specified nested models were performed (Tab. 7 in section 3.3). The first "non- interacted attributes model" included the non-interacted attributes and interactions of socio-demographic variables with the ASC. The second "interaction with PMT variables model" involved significant interactions between the PMT variables and matching attributes.

\subsection{WTA estimation}

\subsubsection{Implicit prices}

The coefficient of the change in income attribute estimated under NL models was used to calculate "implicit prices" (c.f. Bateman et al. 2002, Bennett \& Adamovicz 2001) or marginal WTA. For linear attributes, this was obtained by dividing the monetary attribute coefficient by the coefi- 
cient of each attribute. It was made on a "ceteris paribus" basis, given that everything else is held constant. For non-linear attributes, a base situation was required for calculation of implicit prices. This base situation corresponded to the Status Quo level. Marginal WTA was then calculated by dividing the monetary attribute coefficient by the coefficient of the non-linear attribute. This resultant value was multiplied by the corresponding "marginal" step. The steps represent a change from the status quo level to an adjacent attribute level. Implicit prices were calculated for the best fit model only.

\subsection{Policy assessments}

SPT can represent empowering tools to inform participative-decision making if they are designed and applied according to the CBD Ecosystem Approach principles. The participatory aspects of biodiversity management are strongly emphasized by these principles. By assessing economic non-use and indirect use values of biological diversity, this study describes the potential of a choice experiment to facilitate decision making on biodiversity conservation strategies. These economic values can be used for the optimized design of conservation management options in accordance with local preferences. To illustrate this process of optimization, we show non-market impacts of exemplary changes on biodiversity services of Navarino. A "scenario analysis" is used which is based on likely effects that two areas of most dynamic development, hostelling and fuel wood extraction, could produce to biological diversity of Navarino. Hostelling and fuel wood were chosen because they represent important economic activities that display a strong interaction with biological diversity conservation issues on the island (Barkmann 2004). ${ }^{5}$

Two comprehensive scenarios were considered: "hard" versus "soft" development or, similarly, "biodiversity scenario" versus "pro economic growths scenario". The biodiversity scenario was assumed to be characterized by "ecologically certified fuel wood and reduction of demand" versus "small-scale eco-tourism". The pro economic growths scenario was assumed to be characterized by "cheap fuel wood" versus "intensive tourism". These scenarios are specified in Table 3.

\footnotetext{
${ }^{5}$ The terrestrial focus of the expertise in the BIOKONCHIL project, the much lower availability of data for the marine resources, and the particular conservation value of the temperate terrestrial ecosystems on Navarino justifies this choice. However, this may not be read as an indication that the status of the marine resources would not warrant further investigation. In deed, there are clear signs of overexploitation of (near) open access resources.
} 
Tab. 3: Specification of biodiversity development scenarios for Navarino.

Attribute

"Biodiversity" scenario

"Pro-economic growths" scenario

Change on landscape by impact of tourist infrastructure
Small scale of tourism is implemented.

Small change on landscape.
Hotels and gravel roads are built and installed (see Fig. 2).
Access restrictions to

nature for private No restrictions.

concerns

Access restrictions to nature for conservation concerns
Highly restricted:

Most of the West and South of the island No restrictions. are closed off for conservation initiatives.
Highly restricted:

Most of the West and South of the island are closed off for private development interests.
$25 \%$ more often than now:

Ecologically certified fuel wood and re-

Possibility to see duction of demand leads to effective procarpinteros, guanacos tection of the carpintero. and cóndores
Specific conservation measures are implemented to safeguard the guanaco and cóndor habitats.
$25 \%$ less often than now:

Continued focus on cheap fuel wood and intensive tourism negatively affect habitats.
Secured visit:

The hummingbirds visit the island
The sites where the "notro" (Embothrium coccineum) thickets are present, are protected to secure the visit of the hummingbirds.
Hummingbirds do not come to the island anymore:

Building new routs, hotels and cabins, destroys most of the habitat.

\section{Probability of extinc- tion of an endemic moss}

Very low probability of extinction: Specific small areas are established to protect the moss.
Increased probability of extinction: Intensive firewood extraction and tourism destroy moss habitats.

\section{Ecosystem health \\ 1,600, high level of maintenance: \\ 1,550 small reduction: \\ (number of species) \\ No species are lost. \\ 50 species are lost.}


By substituting model coefficients and attribute levels for the current option (Status Quo), and the attribute levels associated with the changed scenario, utility at the Status Quo, biodiversity and economic growths scenarios was calculated. This calculation required to include the ASC, which captures unobserved information about the choices of respondents.

A "non-market" optimised scenario was evaluated by combining the highest monetary values for each attribute, obtained with the biodiversity and pro-economic growth scenarios.

The differences in utility between the Status Quo and the scenario in question, corresponded to measures of welfare of Navarino residents by changes from the Status Quo to the new scenario. These measures were calculated using the following formula (c.f. Bateman et al. 2002, Bennett \& Blamey 2001):

$\mathrm{WTA}=\left(1 / \beta_{\text {monetary }}\right)\left(\mathrm{U}_{11,12,13}-\mathrm{U}_{0}\right)$

where $\beta_{\text {monetary }}$ is the coefficient of the change in income attribute, $U_{0}$ represents utility at the Status Quo; $\mathrm{U}_{11}, \mathrm{U}_{12}$ and $\mathrm{U}_{13}$ represent utility at the biodiversity, economic growths and optimised scenarios.

\section{Results}

\subsection{Descriptive results}

The choice experiment was administered to 235 local residents of Navarino. It was possible only in part to approximate the population categories of the Census (see Tab. 4). Full randomization could not be achieved as recruiting respondents from groups such as fishermen and construction workers required some snow-ball sampling. Four Census categories (jobless; looking for a job for first time; renting; and private homes with domestic service) could not be covered (see Tab. 4). As expressed by the local government, the "jobless" and "looking for a job for first time" groups regularly leave the island looking for better job opportunities. With regard to the "renting" and "private homes with domestic service" categories, it was not possible to find respondents belonging to these groups at the time of the interview. 
Table 4 shows the covered and non-covered Census categories, as well as the number of people interviewed for each category. The weighting factor used to overcome sampling bias is also shown. Socio-demographic information of the respondents is provided in Table 5. The means and standard deviation of the PMT variables are shown in Table 6 for the entire sample.

Of the 235 interviewed local residents, two persons did not complete the choice task because they perceived the interview as too pro-environmental ("protest answers"), and three respondents were classified as not responding to the CE task because of insufficient cognitive capability to complete the task at the time of the interview. Analyses are based on the remaining 230 respondents. 26 respondents ( $11 \%$ ) always chose the status quo. 204 respondents ( $89 \%$ ) choose option A or B at least once. Ten participants declined to answer the PMT attitudinal questions, mainly because of lacking time. Missing values were substituted by mean values of the PMT variables. 
Tab. 4. Number of persons interviewed classified according to economic activity, and weighting factor used for model estimations.

\begin{tabular}{|c|c|c|c|c|c|c|}
\hline $\begin{array}{l}\text { Total } \\
\text { (perm.) }\end{array}$ & $\begin{array}{c}\text { Permanent } \\
\text { population } \\
>15 \text { years } \\
\text { and } \\
<15 \text { years }\end{array}$ & $\begin{array}{l}\text { Permanent eco- } \\
\text { nomically active } \\
\text { population } \\
\text { vs. } \\
\text { permanent } \\
\text { non-economically } \\
\text { active population }\end{array}$ & $\begin{array}{c}\text { Economic activities } \\
\text { covered and } \\
\text { non-covered by the } \\
\text { study }\end{array}$ & $\begin{array}{l}\text { Census } \\
(\mathbf{N})\end{array}$ & $\begin{array}{l}\text { Sample } \\
\text { (n) }\end{array}$ & $\begin{array}{l}\text { Weighting } \\
\text { factor } \\
\text { (WF) }\end{array}$ \\
\hline \multirow{18}{*}{$N=1960$} & \multirow{17}{*}{$\begin{array}{c}N=1328 \\
(>15 \text { years } \\
\text { old })\end{array}$} & \multirow{16}{*}{$\begin{array}{c}\text { Economically active } \\
\text { population } \\
\mathrm{N}=989\end{array}$} & $\begin{array}{l}\text { Agriculture, livestock, } \\
\text { hunt and silviculture }\end{array}$ & 24 & 4 & 1,04 \\
\hline & & & Artisan Fishing & 114 & 25 & 0,79 \\
\hline & & & $\begin{array}{l}\text { Manufacture indus- } \\
\text { tries }\end{array}$ & 62 & 8 & 1,34 \\
\hline & & & $\begin{array}{l}\text { Electricity, gas and } \\
\text { water supply }\end{array}$ & 8 & 5 & 0,28 \\
\hline & & & Construction & 97 & 16 & 1,05 \\
\hline & & & Commerce & 75 & 23 & 0,59 \\
\hline & & & $\begin{array}{l}\text { Hotels/ hostels/ res- } \\
\text { taurants }\end{array}$ & 15 & 10 & 0,26 \\
\hline & & & $\begin{array}{l}\text { Transport and com- } \\
\text { munications }\end{array}$ & 31 & 5 & 1,07 \\
\hline & & & Financier work & 3 & 1 & 0,52 \\
\hline & & & $\begin{array}{l}\text { Public administration } \\
\text { Civil }\end{array}$ & 70 & 42 & 0,29 \\
\hline & & & Defence & 328 & 28 & 2,03 \\
\hline & & & Teaching & 44 & 11 & 0,69 \\
\hline & & & $\begin{array}{l}\text { Other activities Com- } \\
\text { munitarian, social and } \\
\text { personal services }\end{array}$ & 20 & 11 & 0,31 \\
\hline & & & Jobless & 42 & - & - \\
\hline & & & $\begin{array}{l}\text { Looking for a job for } \\
\text { first time }\end{array}$ & 9 & - & - \\
\hline & & & $\begin{array}{l}\text { Renting/Private } \\
\text { homes with domestic } \\
\text { service }\end{array}$ & 47 & - & - \\
\hline & & $\begin{array}{l}\text { Non economically } \\
\text { active population } \\
\qquad \mathbf{N}=339^{6)}\end{array}$ & Housewife \& Retired & 339 & 41 & 1,43 \\
\hline & $\begin{array}{c}\mathrm{N}=632 \\
(<15 \text { years } \\
\text { old })\end{array}$ & - & - & - & - & - \\
\hline
\end{tabular}

\footnotetext{
6) 67 students, who do not work, are already subtracted from this amount.
} 
Tab. 5. Socio-demographics of the respondents.

\begin{tabular}{l|c|c}
\hline \multicolumn{1}{c|}{ Variable } & Sample average & Navarino average \\
\hline \hline Age (> 15 years old) & 36,3 years & 35,4 years \\
Sex (\%male) (> 15 years old) & $43 \%$ & $67 \%{ }^{7}$ \\
Sex (\%female) (> 15 years old) & $57 \%$ & $33 \%$ \\
Children (\% persons with children) & $80,4 \%$ & Not available \\
Education (years of scholarity) & 12,8 & 11,0 \\
Income [CHP/month] & $\$ 423,348$ & Not available \\
Time on the island (years) & 11,4 & Not available \\
Expected time on the island in the future \\
(years)
\end{tabular}

Tab. 6. PMT variables.

\begin{tabular}{llcc}
\hline \hline Attribute & PMT variable & Mean value & $\begin{array}{c}\text { Standard devia- } \\
\text { tion }\end{array}$ \\
\hline \hline $\begin{array}{l}\text { Change on landscape by impact of } \\
\text { tourist infrastructure }\end{array}$ & Value & 3,35 & 0,69 \\
\cline { 2 - 4 } $\begin{array}{l}\text { Access restrictions to nature for } \\
\text { private concerns }\end{array}$ & Likelihood & 2,34 & 0,80 \\
$\begin{array}{l}\text { Access restrictions to nature for } \\
\text { conservation concerns }\end{array}$ & Value & 3,56 & 0,65 \\
\hline $\begin{array}{l}\text { Possibility to see carpinteros, gua- } \\
\text { nacos and cóndores }\end{array}$ & Value & 3,28 & \\
\hline The hummingbirds visit the island & Self-efficacy & 2,92 & 0,76 \\
\hline $\begin{array}{l}\text { Probability of extinction of an } \\
\text { endemic moss }\end{array}$ & Value & 3,00 & 0,77 \\
\hline & Severity & 2,94 & 0,78 \\
\hline Ecosystem health & Value & 3,47 & 0,80 \\
\cline { 2 - 4 } & Severity & 3,19 & 0,75 \\
\hline \hline
\end{tabular}

\subsection{General qualitative results}

In this section we present general results of the qualitative questions included in the main $\mathrm{CE}$ questionnaire (see Appendix 1; CE questionnaire). Those questions were mainly related to the change on landscape by tourist infrastructure, possibility to see animals and visits of the hum-

\footnotetext{
${ }^{7}$ This porcentage includes $\sim 240$ people who are not permanent residents of Navarino, and are present on the island only for the king-crab extraction period.
} 
mingbirds attributes. The qualitative results related to the existence of an endemic moss attribute are shown and analysed in detail, in Chapter IV of the dissertation.

We emphasize the following results:

a) We included a question in which the participants had to express advantages and disadvantages related to higher levels of change on landscape by new infrastructure for tourism. More money and economic growth were mentioned as the most important advantages. On the other hand, contamination and forest destruction were the main disadvantages mentioned by the respondents. These results indicate that the participants not only perceive the damage on landscape that additional tourist infrastructure could produce, but also, the economic advantages of this implementation.

b) Most of the respondents had seen the carpintero and the cóndor on the island. A few respondents, however, had experienced seeing the guanaco, because it is difficult to find this animal in the more frequently visited places of Navarino.

c) Only a few respondents expressed to have seen hummingbirds on the island. Additionally, only a few respondents knew of its importance in old Yaghan stories when indirectly asked: Do you know anything about this bird, could you tell me anything? Even of the thirteen Yagan community respondents, only two mentioned the importance of this bird for the Yagan culture.

\subsection{Econometric results}

Table 7 shows results from two performed Nested Models. With $\mathrm{p}<0.0001$, model (b) that includes interactions with PMT variables (likelihood ratio statistics $=42 ; \chi_{(1 \mathrm{DF})}^{2}=5.99$ at $\alpha=0.05$ ) fits better than model (a).

In model (a), with exception of the possibility to see carpinteros, guanacos and cóndores attribute $(\mathrm{P}=0.46)$, all included terms are significant at $\mathrm{P} \leq 0.5$. For linear environmental attributes the signs of the coefficients are positive indicating that more of the attribute does, on average, increase the probability of an option being chosen. For non-linear attributes the signs are expected because of the adjusted coding for the levels of the attributes (see Tab. 1). The sign of the monetary attribute 
is positive, as expected, for a WTA instrument format.

In model (b) we observe:

- No influence on choice is observed for the possibility to see animals attribute, either.

- The coefficient of the value item for landscape results negative $(\mathrm{P} \leq 0.05)$. This indicates that if for the respondent is very important to keep the actual landscape of Navarino, more levels of tourist infrastructure would decrease the utility.

- The interaction between the value item and access restriction for both, private $(\mathrm{P}<0.001)$ and conservation $(\mathrm{P}<0.01)$ concerns, results positive. It would be expected that when the importance of keeping free access on the island is higher, the correlation with the attribute should be negative as this represents more levels of restrictions. One has to keep in mind, however, that those places of the island preferred for recreation were no restricted.

- Compared to the non-interacted attributes model (a), the hummingbirds visits attribute keeps high significance when interacted with the PMT self-efficacy item $(\mathrm{P}<0.001)$. If respondents think that can do something to contribute to a more secure visit of this species, they value the hummingbirds visits more.

- The moss value item, also explains preferences when interacted with the moss attribute $(\mathrm{P}<0.001)$. As expected, higher value results in stronger preferences.

- The severity PMT item is highly significant in explaining preferences for ecosystem health, indicating that if the respondent agrees with a statement on negative effects of a reduced ecosystem health, he/she will stronger prefer scenarios in which more species are present.

In both models, the monetary attribute "income change" is highly significant.

Results from both models that included EDUCATION effects, indicate that this variable has statistically significant effects on choosing option A or B. The ASC*Education coefficient shows that more years of education result in a decreased attractivity of the offered changes versus the status quo. 
Tab. 7. Nested Logit models.

$\begin{array}{ccc}\text { Variable } & \text { (a) Non-Interacted } \\ \text { attributes } & \text { (b) Interaction with } \\ \text { PMT variables }\end{array}$

Landscape Change

Non-interacted attribute

$\odot . \odot 999 * *$

$0.4473^{* *}$

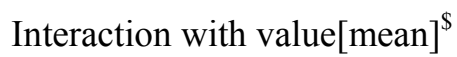

$-0.3443^{*}$

\section{Access Restrictions (private)}

Non-interacted attribute

$\odot .1485^{* * *}$

Interaction with value[mean $]^{\$}$

$-\quad 0.1684^{* * *}$

Access Restrictions (conservation)

Non-interacted attribute

0.1096 **

Interaction with value[mean] $^{\S}$

$-\quad 0.1103^{*}$ *

Possibility to see carpinteros, guanacos and cóndores

Non-interacted attribute

$0.0213^{(\mathrm{ns})}$

$\odot .0199^{(\mathrm{ns})}$

Visits of hummingbirds with ethno-symbolic value

Non-interacted attribute

$\odot .5773^{* * *}$

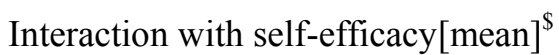

-

$0.5869 * * *$

\section{Moss existence}

Non-interacted attribute

$0.2301^{* * *}$

Interaction with value[mean $]^{\$}$

\section{Ecosystem Health}

Non-interacted attribute

$0.0006 * * *$

Interaction with severity[mean $]^{\S}$

\begin{tabular}{|c|c|c|}
\hline Income Change $\$$ & $0.0067 * * *$ & $0.0070^{* * *}$ \\
\hline ASC $^{*}$ Education $[\text { mean }]^{\$}$ & $-0.3648 * * *$ & $-0.3193 * * *$ \\
\hline Log-likelihood & -1641.26 & -1620.26 \\
\hline Restricted Log-likelihhod & -2109.17 & -2109.17 \\
\hline $\mathbf{P}\left(\mathrm{Chi}^{2}\right) ; \mathrm{DF}$ & $<0.0001 ; 10$ & $<0.0001 ; 11$ \\
\hline Inclusive value (IV) ${ }^{\#}$ & 0.9842 & 0.9853 \\
\hline Adj. $\rho^{2}$ (Pseudo-R $\left.{ }^{2}\right)$ & 0.2197 & 0.2295 \\
\hline
\end{tabular}

***: significant at $\mathrm{p} \leq 0.001 ; * *$ : significant at $\mathrm{p} \leq 0.01 ; *$ : significant at $\mathrm{p} \leq 0.05 ;{ }^{\$}$ raw coefficients multiplied with the sample means (see Tables 5 and 6); ${ }^{\S}$ cost coefficients for $1,000 \mathrm{CHP} / \mathrm{yr} /$ household; DF: degrees of freedom; ${ }^{*}$ all IV statistics are highly significantly different from 0 ; Nested Logit models based on 230 respondents with 8 choices each: $n=8 * 230=1840$ observations. 


\subsection{Estimation of willingness to accept}

\subsubsection{Marginal WTA}

Based on model (b), which fits the data better than model (a) and contains interactions of the attributes with the PMT variables, Table 8 shows marginal WTA values (implicit prices) for an average respondent.

Because the non-linear, inverted U-shape coding results in changing marginal WTA values for the landscape change attribute, the 'marginal' step used for calculation is explicitly given (see Tab. 8). The values for the landscape change attribute indicate that, on average, respondents have a WTA of $\sim 29,340 \mathrm{CHP} /$ month for additional infrastructure resulting in small change to the landscape. Because of the positive utility associated to small change on landscape as indicated by our dummy-coding analysis, this value can be interpreted as the minimum amount of money that would compensate to the respondents if the small change on landscape is not implemented.

Marginal WTA is higher for access restriction by private concerns than for conservation, with a difference of $\sim 4,280 \mathrm{CHP} /$ month. The positive sign of the attribute coefficient (see Tab. 7, model b), indicates higher utility associated with additional levels of restrictions for both conservation and private initiatives. The minimum compensation that would be required by local residents if no additional restriction for private initiatives is established is $\sim 20,000$, and for conservation concerns $\sim 15,720 \mathrm{CHP} /$ month.

Marginal changes in the attribute levels on hummingbird presence result in the highest WTA values in excess of $\sim 83,000 \mathrm{CHP} /$ month. This amount represents the minimum monetary compensation required by local residents for one additional level of less secure presence.

The marginal step used for the calculation of marginal WTA for the existence of an endemic moss attribute is given (see Tab. 8). The step is from low probability of extinction (Status Quo) to increased probability of extinction. Marginal WTA is $\sim 61,350 \mathrm{CHP} /$ month for increased probability of extinction. 
Marginal WTA for the loss of one of about 1600 species in the island with respect to this species contribution to the "health, vigour, and resistance of nature" is $\sim 100 \mathrm{CHP} / \mathrm{month}$.

The ASC interaction indicates that respondents, on average, have a status quo bias equivalent to $\sim 45,500 \mathrm{CHP} /$ month.

Tab. 8. Estimates of Implicit Prices (in Chilean Pesos) ( $\mathrm{n}=230)$.

\begin{tabular}{|c|c|c|c|}
\hline Attribute & $\begin{array}{c}\text { "Marginal"§ Unit } \\
\text { used for calculation } \\
\text { coding } \\
\end{array}$ & $\begin{array}{c}\text { WTA } \\
{[\text { CHP/month] }}\end{array}$ & $\sum$ \\
\hline $\begin{array}{l}\text { Change of landscape by impact of tourist infra- } \\
\text { structure } \\
\text { Change of landscape by impact of tourist infra- } \\
\text { structure*[value mean] }\end{array}$ & $\begin{array}{l}\text { Very small change }(-1) \\
\text { to small change }(+1)^{\S} \\
\text { Very small change }(-1) \\
\text { to small change }(+1)^{\S}\end{array}$ & 127,499 & 29,337 \\
\hline $\begin{array}{l}\text { Access restrictions to nature for private con- } \\
\text { cerns*[value mean }{ }^{\$} \\
\text { Access restrictions to nature for conservation } \\
\text { concerns*[value mean] }\end{array}$ & Next restriction level & 20,005 & 35,728 \\
\hline $\begin{array}{l}\text { Possibility to see woodpeckers, guanacos and } \\
\text { cóndores }\end{array}$ & - & - & - \\
\hline $\begin{array}{l}\text { The hummingbirds visit the } \\
\text { island*[self-efficacy mean }]^{\$}\end{array}$ & $\begin{array}{l}\text { Next level of securing } \\
\text { humming bird presence }\end{array}$ & 83,637 & 83,637 \\
\hline $\begin{array}{l}\text { Probability of extinction of an endemic } \\
\text { moss*[value mean }]^{\$}\end{array}$ & $\begin{array}{l}\text { Low probability of extinc- } \\
\text { tion }(+1) \\
\text { to increased probability } \\
\text { of extinction }(-1)^{\S}\end{array}$ & 61,348 & 61,348 \\
\hline $\begin{array}{l}\text { Number of types of animals and plants indicat- } \\
\text { ing "health, resistance and vigour } \\
\text { of nature"*[severity mean }]^{\S}\end{array}$ & $\begin{array}{l}\text { Loss of } 1 \text { of } 1600 \text { species } \\
\text { on the island }\end{array}$ & 99 & 99 \\
\hline ASC*Education [*mean Education] & $\begin{array}{l}\text { Deviation from status quo } \\
\text { as offered by choices }\end{array}$ & $-45,503$ & $-45,503$ \\
\hline
\end{tabular}

${ }^{\S}$ The marginal step represents a change from a status quo level to an adjacent attribute level; ${ }^{\$}$ raw coefficients multiplied with the sample means.

\subsubsection{Scenario analysis}

Table 9, shows the scenario analysis results. As we used a payment vehicle mostly operationalized by increases in income, the results are described as WTA.

The numbers indicate that the biodiversity scenario increases utility by $\sim \$ 98,918 \mathrm{CHP} / \mathrm{month}$, when compared to the utility at the status quo. This amount represents the minimum monetary compensation that would be required by Navarino local residents, if the scenario is not imple- 
mented. Differently, utility decreases by $\sim \$ 170,000 \mathrm{CHP} /$ month, respect to the current situation, if a hard development scenario is implemented. This represents minimum WTA if the scenario is carried out.

An optimised scenario generates a gain in utility of $\sim \$ 124,259 \mathrm{CHP} /$ month with respect to the Status Quo. This value can be interpreted as the amount of money that would compensate to people to go without the change.

With a more detailed analysis of the single attributes, a higher utility with respect to the Status Quo is observed, if a small change on landscape is implemented. The highly restricted access for both private and conservation concerns generates higher utility as indicated by the biodiversity and pro-economic growths scenarios. The most secure level of hummingbirds visit produces highest benefits for the respondents. With respect to the Status Quo, the utility does not increase by a very low probability of moss extinction. However, it turns out to be negative when the probability of extinction increases. The lost of 50 species of the island produces, in average, a lost in utility of $\sim \$ 4,950 \mathrm{CHP} /$ month, when compared to the utility at the status quo. 
Tab. 9. Scenario analysis, measures of welfare (in CHP/month).

\begin{tabular}{|c|c|c|c|c|c|c|c|c|}
\hline Attribute & $\begin{array}{c}\text { Status } \\
\text { Quo } \\
\text { (level code) }\end{array}$ & WTA & $\begin{array}{l}\text { Biodiversity } \\
\text { conservation } \\
\text { scenario } \\
\text { (level code) }\end{array}$ & WTA & $\begin{array}{l}\text { Pro-economic } \\
\text { growths } \\
\text { scenario } \\
\text { (level code) }\end{array}$ & WTA & $\begin{array}{l}\text { Non-market } \\
\text { optimized } \\
\text { scenario } \\
\text { (level code) }\end{array}$ & WTA \\
\hline $\begin{array}{l}\text { Change of landscape by } \\
\text { impact of tourist } \\
\text { Infrastructure } \\
\end{array}$ & $\begin{array}{c}\text { Very small } \\
\text { change } \\
(-1) \\
\end{array}$ & $-14,669$ & $\begin{array}{l}\text { Small change } \\
\text { (1) }\end{array}$ & 14,669 & $\begin{array}{l}\text { Big change } \\
(-2)\end{array}$ & $-29,337$ & $\begin{array}{l}\text { Small change } \\
\text { (1) }\end{array}$ & 14,669 \\
\hline \multirow{2}{*}{$\begin{array}{l}\text { Access restrictions to } \\
\text { nature for private concerns } \\
\text { Access restrictions to } \\
\text { nature for conservation } \\
\text { concerns } \\
\end{array}$} & $\begin{array}{l}\text { No restrictions } \\
\text { (1) }\end{array}$ & 20,005 & $\begin{array}{l}\text { No restrictions } \\
\text { (1) }\end{array}$ & 20,005 & $\begin{array}{l}\text { Highly restricted } \\
\text { (3) }\end{array}$ & 60,015 & $\begin{array}{l}\text { Highly restricted } \\
\text { (3) }\end{array}$ & 60,015 \\
\hline & $\begin{array}{l}\text { No restrictions } \\
\text { (1) }\end{array}$ & 15,723 & $\begin{array}{l}\text { Highly restricted } \\
\text { (3) }\end{array}$ & 47,169 & $\begin{array}{c}\text { No restrictions } \\
\text { (1) }\end{array}$ & 15,723 & $\begin{array}{l}\text { Highly restricted } \\
\text { (3) }\end{array}$ & 47,169 \\
\hline Possibility to see animals ${ }^{8}$ & $\begin{array}{l}\text { As often as now } \\
(2)\end{array}$ & - & $\begin{array}{l}25 \% \text { more often than now } \\
(1)\end{array}$ & - & $\begin{array}{l}25 \% \text { less often than now } \\
(-2)\end{array}$ & - & $\begin{array}{l}\text { As now } \\
(2)\end{array}$ & - \\
\hline $\begin{array}{l}\text { The hummingbirds visit } \\
\text { the island }\end{array}$ & $\begin{array}{c}\text { Non-secure visit } \\
(0)\end{array}$ & 0 & $\begin{array}{l}\text { Secure visit } \\
\text { (1) }\end{array}$ & 83,637 & $\begin{array}{l}\text { They do not come to the } \\
\text { island anymore } \\
(-1)\end{array}$ & $-83,637$ & $\begin{array}{l}\text { Secure visit } \\
\text { (1) }\end{array}$ & 83,637 \\
\hline $\begin{array}{l}\text { Probability of extinction of } \\
\text { an endemic moss }\end{array}$ & $\begin{array}{l}\text { Low } \\
(1)\end{array}$ & 30,674 & $\begin{array}{c}\text { Very low probability of } \\
\text { extinction } \\
\text { (1) }\end{array}$ & 30,674 & $\begin{array}{c}\text { Increased probability of } \\
\text { extinction } \\
(-1)\end{array}$ & $-30,674$ & $\begin{array}{l}\text { Low probability of } \\
\text { extinction } \\
\text { (1) }\end{array}$ & 30,674 \\
\hline $\begin{array}{l}\text { Number of types of } \\
\text { animals and plants }\end{array}$ & 1600 & 158,400 & No species are lost (1600) & 158,400 & 50 species are lost $(1550)$ & 153,450 & $\begin{array}{c}\text { No species are lost } \\
(1600)\end{array}$ & 158,400 \\
\hline \begin{tabular}{|l|} 
ASC*Education \\
[*mean Education] \\
\end{tabular} & - & - & & $-45,503$ & & $-45,503$ & & $-45,503$ \\
\hline$\sum$ & & 210,133 & & 309,051 & & 40,037 & & 334,392 \\
\hline \multicolumn{3}{|c|}{$\begin{array}{c}\text { Compensating variation measure } \\
{[\text { CHP/month] }} \\
\left(\mathbf{U}_{11,12,13}-\mathbf{U}_{0}\right)\end{array}$} & $+98,918$ & & \multicolumn{2}{|l|}{$-170,096$} & \multicolumn{2}{|l|}{$+124,259$} \\
\hline
\end{tabular}

\footnotetext{
${ }^{8}$ Because of no significance of the attribute, it is not included.
} 


\section{Discussion and conclusions}

\subsection{Methodological aspects}

The research reported in this chapter represents, to our knowledge, the first attempt to use choice experiments to value biological diversity in Chile. We had the opportunity to work on some disciplinary aspects: a) exploration of the potential of choice experiment to effectively isolate biological diversity attributes, b) exploration of the images of nature concept as an procedure that yields appropriated data for the implementation of stated preference techniques and c) to obtain first empirical evidence for the "existence" of a willingness-to-accept for functional ecosystem health in the sense of a biodiversity-provided ecosystem service that insures against unknown threats to the human-nature relation.

The results, added to well understanding of the choice task of the participants, provide evidence that choice experiments can be applied to the valuation of biodiversity in a socially diverse, remote area in a threshold country like Chile. No respondent expressly manifested doubts over the likely changes offered and consequently over the scenarios to be implemented. Additionally, no respondent expressed protests responses caused by ethical concerns on trading-off the protection of species against a compensation in money (for details see Cerda et al., this thesis).

The concurrent utilisation of six biodiversity-related attributes facilitated the isolation of biodiversity values. Participants traded-off different biodiversity-related goods and services, against a monetary attribute.

\subsection{Results}

Two different nested models were used to predict respondents' choices: a standard nested logit model with non-interacted attributes and a nested model including interactions between attributes and PMT variables (see Tab. 7). The performed NL models were found to be statistically significant and having acceptable explanatory power.

As was hiphotesized in the begining, PMT attitudinal variables would explain individual preference variations generated from - hypothetical - stated preference surveys. Significance of PMT attitudinal variables was found by significantly better fits model. Three PMT variables: value, self-efficacy and severity, had significant explanatory effects on dependent variable 
"choice".

With the exception of the aesthetic biodiversity attribute (possibility to see carpinteros, guanacos and cóndores), attributes influenced respondents choices of which non-market biodiversity scenario to choose. Strong positive effects of landscape aesthetics threatened by progressing levels of tourist infrastructure, nature access restriction for both economic and conservation concerns, continued visits of the ethno-culturally important hummingbirds, protection for an endemic moss and ecosystem resilience provided by species diversity, were noted in the models. The payment vehicle, "change on income/month", entered positively into respondents utility functions, because of the WTA format used in the study. The significance of the monetary attribute indicates that respondents evaluated change on income as an important factor. This means that the Navarino local residents act as income change-sensitive consumers in the context of the island's biodiversity management. While absolute values may be "inflated" allowing choices based on WTA considerations, this does not impact "inner-biodiversity" preference patterns, however.

At a more detailed analysis of the single attributes included in the study, for the change on landscape by impact of tourist infrastructure attribute the results clearly indicate that people are willing to accept landscape changes in favour of additional tourist infrastructure, but, at a certain limit. Our dummy-coded analysis indicated that the utility turns out to be negative with the large scale tourist infrastructure. The most preferred levels of landscape change are "small" and "medium" (see Tab. 1). The economic advantages that the respondents perceived from additional levels of tourist infrastructure (see section 3.2) were clearly decisive to prefer tourism development at small and medium scales. The disadvantages of additional infrastructure (see section 3.2), mainly related to forest damage and contamination, may explain the negative utility associated with the highest level of change on landscape.

The results indicate, therefore, that the respondents not only perceived the damage on landscape but also the economic benefits of additional infrastructure on the island.

Based on the qualitative interview data (see sec. 2.4.1), it was expected that stronger restrictions of access to nature would negatively influence the respondents' utility. The qualitative interviews had indicated the importance of free access to the island. However, the NL models results indi- 
cate that restrictions for, both, private (such as tourism development) and conservation concerns, are positively valued by the respondents. Most likely, some respondents associated the restrictions for private initiatives (e.g., tourism) business development - which could mean more employment or investment options on the island. This scenario is, in fact, quite likely as large land concessions at the West coast of Navarino were granted recently for tourism. Many respondents perceive tourism as the major economic of development opportunity on Navarino. On the other hand, conservation appears to be accepted by the local residents as well - even if it results in access restrictions to some places of the island. With regard to the apparent contradiction between the importance of access to nature and landscape expressed by the residents in the qualitative phase of the study, one has to keep in mind that we - realistically - 'closed off' access only for those parts of the island that are - by the vast majority of residents - not used actively for recreation.

During our choice experiment application, only a few respondents expressed to have seen hummingbirds on the island (see section 3.2). Even of the thirteen Yagan community respondents, only two mentioned the importance of this bird for the Yagan culture. However, this attribute was very strongly valued by respondents - if the value was explained in the CE interview. The value indicates a substantial appreciation of the Yagan culture by the participants of our study.

It was tested whether insurance benefits species diversity (c.f. ecological insurance hypothesis) can be materialised empirically as WTA. The responses to the qualitative questions included in the CE questionnaire reflect that respondents understood the explanations for this "unfamiliar" ecosystem services well (c.f. Barkmann et al. 2006); the attribute's high significance indicates preferences for protecting fundamental ecosystem functioning. Although the economic value obtained seems to be low, the results constitute the first direct empirical evidence for economic preferences for insurance services by species richness against unknown threats to the humannature relation. This could also be interpreted as an evidence of preferences for primary values (c.f. Turner 1999, Barkmann \& Marggraf 2004). 
The concurrent utilisation of six biodiversity-related attributes, four of which focuse on different value aspects of species diversity, facilitated the isolation of existence values. This indicates that the choice experiment approach represents a suitable way in attempting to estimate existence values of single species, generating a meaningful marginal value for the existence of an endemic species for Navarino island residents (for details see Cerda et al., this thesis).

\subsection{Policy implications}

While the actual land use planning of Navarino favours tourism projects at high scales, the local citizens favour a different model of development. The optimized scenario (see tab. 9) clearly shows that people appear having a balance between economic development and biodiversity preservation. Local residents prefer small scale of tourism development, private initiatives are also well seen even if they result in access restriction to the landscape of Navarino. On the other hand, people appreciate the natural and cultural heritage of the island. They accept access restrictions to nature for conservation and are willing to support the protection of animals and plants of the place, specially the hummingbirds.

Because the local and regional decision-makers expressed strong interest in cost-benefit-type results from this study, it was decided to use a choice experiment conducted with individual respondents because this is a standard method in environmental economics. The results can later be used for cost-benefit analysis (c.f. Hanley \& Spash 1993) of different development options.

\subsection{CBD Ecosystem Approach: Economics and Participation}

Although the decision of using a choice experiment conducted with individual respondents precluded the application of more strongly participative valuation techniques, such group valuation (Wilson \& Howarth 2002), following the lines of the CBD Ecosystem Approach the application includes participative aspects:

- Assessment of the limitations and opportunities of the choice experiment as a stated preference technique informing early or ill-structured decision-making processes. 
- Particular biodiversity structures and processes directly based on the input from the extensive qualitative phase of the images of nature analysis were identified. These identification was essential for the development of the $\mathrm{CE}$ instrument and useful for the interpretation of the results.

- The choice experiment itself is a tool to give to the local respondents an "economic voice" with regard to different sustainable development scenarios on the island.

- As the Chilean administrative system remains highly centralistic, and as revealed by our respondents, the decision-making process is inaccessible and intransparent to most local residents, our study contributed at improving the opportunities and capacity of the local population to participate actively in the design of a socially, economically and ecologically sustainable future of the island. Results were introduced at public exhibitions on sustainable development on Navarino island, distributed to local decision makers and published in the regional newspaper. The idea is to promote intensive discussion on management plan of the Cape Horn Biosphere Reserve and development strategies.

As the CBD Ecosystem Approach supports strongly the local participation in the design of conservation measures, it will be very important to find the appropriated equilibrium between conservation and local economic interests. This study can usefully contribute to shed lights on giving lines for a sustainable development favoured by local residents of Navarino. 


\section{Literature}

Adamovicz, W. L., Boxall, P., Williams, M. \& Louviere, J. (1998). Stated Preference Approaches for measuring passive use values: Choice Experiments and Contingent Valuation. American Journal of Agricultural Economics 80, 64-75.

Arrow, K., Solow, R., Portney, P. R., Learner, E. E., Radner, R. \& Schuman, H. (1993). Report of the NOAA Panel on Contingent Valuation. Washington, D. C.: Resources for the Future.

Barkmann, J., Baumann, R., Meyer, U., Müller, F. \& Windhorst, W. (2001). Ökologische Integrität: Risikovorsorge im nachhaltigen Landschaftsmanagement. Gaia 10(2), 97-108.

Barkmann, J. (2004). Proposal for the work with sustainable development scenarios in BIOKONCHIL. BIOKONCHIL, internal draft.

Barkmann, J. \& Marggraf, R. (2004). The long-term protection of biological diversity - lessons from market ethics. Poiesis \& Praxis - International Journal of Ethics and Technology Assessment 3, 3-21.

Barkmann, J., Cerda, C. \& Marggraf, R. (2005). Interdisziplinäre Analyse von Naturbildern: Notwendige Voraussetzung für die ökonomische Bewertung der natürlichen Umwelt. Umweltpsychologie 9, 10-28.

Barkmann, J., De Vries, K., Dietrich, N., Glenk, K., Keil, A., Leemhuis, C. \& Marggraf, R. (2006). Confronting unfamiliarity with ecosystem functions: The case for an ecosystem service approach to environmental valuation with stated preference methods. Submitted (Ecological Economics). 
Bateman, I., Carson, R., Day, B., Hanemann, M., Hanley, N., Hett, T., Jones-Lee, M., Loomes, G., Mourato, S., Özdemiroglu, E., Pearce OBE, D.W., Sugden, R., \& Swanson, R. (eds.). (2002). Economic Valuation with Stated Preference Techniques: A Manual. Cheltenham: Edward Elgar.

Bennett, J. \& Blamey, R. (eds.). (2001). The Choice Modelling Approach to Environmental Valuation. Cheltenham: Edward Elgar.

Berghöfer, U. (2005). Imágenes de Naturaleza en isla Navarino. In: Arango, X., Berghöfer, A., Berghöfer, U., Cerda, C., Draguicevic, J., Fistric, S., Jax, K., Ojeda, M., Rozzi, R., Schüttler, E. (eds.): Vivir en la isla Navarino: Un mundo diverso en el fin del mundo (pp. 24-32). Leipzig-Halle: Centre for Environmental Research (UFZ).

Blamey R. K., Bennett, J. W., Louviere, J. Morrison, M. S. \& Rolfe, J. (2000). A test of policy labels in environmental choice modelling studies. Ecological Economics 32, 269-286.

Boxall, P. C., Adamovicz, W. L., Swait, J., Williams, M. \& Louviere, J. (1996). A comparison of Stated Preference Methods for Environmental Valuation. Ecological Economics 188, 243253.

Bühl, A. \& Zöfel, P. (Hrsg.). (2000). SPSS Version 10. Einführung in die moderne Datenanalyse unter Windows. München: Addison-Wesley.

Carson T., Mitchell, R., Hanemann, R., Kopp, R., Presser, S. \& Ruud, P. (2003). Contingent Valuation and Lost Passive Use: Damages from the Exxon Valdez Oil Spill. Environmental and Resource Economics 25, 257-286.

Cerda, C., Barkmann, J. \& Marggraf, R. (2005). Assessment of Biological Diversity in the context of the CBD Ecosystem Approach: The Participatory Potential of Economic Valuation Techniques. Poster presentation at the international conference: "Biodiversity: Science and 
Governance”. Paris, January 24-28, 2005.

Cerda, C., Barkmann, J., Marggraf, R. (2006). Trading-off the existence of an endemic moss? Empirical results from a case study at the extreme South of the Americas. Chapter IV, this thesis.

Colombo, S., Calatrava-Requena, J. \& Hanley, N. (2005). Designing policy for reducing the offfarm effects of soil erosion using Choice Experiment. Journal of Agricultural Economics 56(1), 81-95.

Costanza, R., Norton, B. G. \& Haskell, B. D. (eds.). (1992). Ecosystem Health - New Goals for Environmental Management. Washington, D.C.: Island Press.

Diamond, P. \& Hausman, J. A. (1994). Contingent Valuation: Is some number better than no number?. Journal of Economic Perspectives 8(4),45-64.

Gardner, G. T. \& Stern, P. C. (eds.) (1996). Environmental Problems and Human Behaviour. Boston: Allyn and Bacon.

Green, C. \& Tunstall, S. (1999). A psychological perspective. In: Bateman, J. \& Willis, K. (eds): Valuing Environmental Preferences. Theory and Practice of the Contingent Valuation Method in the US, EU, and Developing Countries (pp. 207-257). Oxford (UK): Oxford University Press.

Hanley, N. \& Spash, C. (eds.) (1993). Cost - Benefit Analysis and the Environment. Vermont: Edwar Elgar.

Hanley, N., Wright, R. \& Adamowicz, W. (1998). Contingent Valuation versus Choice Experiments : Estimating the Benefits of Environmentally Sensitive Areas in Scotland. Journal of Agricultural Economics 49(1), 1-15. 
Hanley, N., Mourato, S. \& Wright, R. (2001). Choice Modelling Approaches: A superior Alternative for Environmental Valuation?. Journal of Economic Surveys 15(3), 435-462.

Hausmann, J. \& McFadden, D. (1984). Specification tests for the multinomial logit model. Econometrica 52, 1219-1240.

Hensher, D., Rose, J. \& Greene, W. (eds.). (2005). Applied Choice Methods - A Primer. Cambridge (UK): Cambridge University Press.

Horne, P. \& Petäjistö, L. (2003). Preferences for alternative moose management regimes among Finnish landowners: a choice experiment approach. Land Economics 79(4), 472-482.

INE (2002). Censo Nacional de Población. Instituto Nacional de Estadísticas. Chile.

Available at: www.ine.cl

IUCN (2000). Economics and the Convention on Biological Diversity. Available at: http://www.undp.org/bpsp/thematic_links/IUCN2.pdf.

Jax, K. (2005). Navarino - ein gefährdetes Inselparadies. In: Roth, S. (Hg.): BioTeam - Biodiversitätsforschung für die Anwendung (S. 18-19). Berlin: Bundesministerium für Bildung und Forschung (BMBF).

Jax, K., Berghöfer, U. \& Fistric, S. (2005). Navarino Ecosystem Profile. BIOKONCHIL Ecological Subproject. Internal draft.

Jax, K., Marggraf, R. \& Rozzi, R. (eds.). (2007): Evaluation of biological diversity under the perspective of the Ecosystem Approach of the Convention on Biological Diversity, on the basis of the case study of the island Navarino (southern Chile, Tierra del Fuego, Cape Horn 
Archipelago). Research report. Leipzig: Bundesministerium für Bildung und Forschung, Grant 01LM0208, (in press).

Kahneman, D. \& Knetsch, J. L. (1992). Valuing public goods: The purchase of moral satisfaction. Journal of Environmental Economics and Management 22, 57-70.

Kutsch, W. L., Steinborn, W., Herbst, M., Baumann, R., Barkmann, J. \& Kappen, L. (2001). Environmental Indication: A field-test of an Ecosystem Approach to Quantify Biological Self-organization. Ecosystems 1, 49-66.

Louviere, J. \& Hensher, D. A. (1982). On the Design and Analysis of Simulated Choice or Allocation Experiments in Travel Choice Modeling. Transportation Research Record 890, 11-17.

Louviere, J. \& Woodworth, G. G. (1983). Design and Analysis of Simulated Consumer Choice or Allocation Experiments: An Approach Based on Aggregated Data. Journal of Marketing Research 20, 350-367.

Louviere, J., Hensher, D. A. \& Swait, J. D. (eds.). (2000). Stated Choice Methods - Analysis and Application. Cambridge (UK): Cambridge University Press.

Louviere, J. (2001). What if consumer experiments impact variances as well as means?. Response variability as a behavioural Phenomenon. Journal of Consumer Research 28, 506511.

Manski, C. (1977). The structure of random utility models. Theory and Decision 8, 229-254.

Marggraf, R. \& Streb, S. (1997). Ökonomische Bewertung der natürlichen Umwelt. Theorie, politische Bedeutung, ethische Diskussion. Heidelberg/Berlin: Spektrum Akademischer Verlag.

McFadden, D. (1973). Conditional logit analysis of qualitative choice behavior. In. P. Zarembka 
(ed.): Frontiers in Econometric (pp. 105-142). New York: Academic Press.

McNeely, J. 1988 (ed.). Ecological and Biological Diversity: Developing and Using Economic Incentives to Conserve Biological Resources. IUCN, Gland, Switzerland.

Menzel, S. (2003). Der Beitrag der Protection Motivation Theory für Interpretation von Zahlungsbereitschaftsäußerungen zur Erhaltung biologischer Vielfalt. Umweltpsychologie 7, 92-112.

Mishan, E. J. (1971). The post-war literature on externalities: an interpretative essay. Journal of Economic Literature 9, 1-28.

Mogas, J., Riera, P. \& Bennett, J. (2005). Accounting for afforestation externalities: A comparison of Contingent Valuation and Choice Modelling. European Environment 15, 44-58.

Naidoo, R. \& Adamowicz, W. (2005). Biodiversity and nature-based tourism at forest reserves in Uganda. Environment and Development Economics 10, 159-178.

Othman, J., Bennett, J. \& Blamey, R. (2004). Environmental Values and Resource Management Options: A Choice Modelling experience in Malaysia. Environmental and Development Economics 9, 803-824.

Pearce, D. (ed.). (1993). Economic Values and the Natural World. London: Earthscan.

Pearce, D. W. \& Moran, D. (eds.). (1994). The Economic Value of Biodiversity. IUCN - The World Conservation Union. London: Earthscan.

Pearce, D. \& Barbier, E. (eds.). (2000). Blueprint for a Sustainable Economy. London: Earthscan. 
Pearce, D. \& Özdemiroglu E. (eds.) (2002). Economic Valuation with Stated Preference Techniques. Summary Guide. London: Department for Transport, Local Government and the Regions.

Rogers, R. \& Prentice-Dunn, S. (1997). Protection Motivation Theory. In: D. S. Gochman (ed.): Handbook of Health Behaviour Research (pp. 113-132). New York: Plenum.

Rolfe, J., Bennett, J. \& Louviere J. (2000). Choice Modelling and its Potential Application to Tropical Rainforest Preservation. Ecological Economics 35, 289-302.

Roth, S. (Hg.). (2005). BioTeam- Biodiversitätsforschung für die Anwendung. Bundesministerium für Bildung und Forschung. Bonn: PT-DLR Umweltforschung Projektträger des BMBF.

Rozzi, R. (ed.). (2003). Guía Multi-étnica de Aves de los Bosques Templados de Sudamérica Austral. Magallanes: Fantástico Sur - Birding \& Nature.

Rozzi, R., Massardo, F. \& Anderson, C. (eds.). (2004). The Cape Horn Biosphere Reserve: A Proposal for Conservation and Tourism to Achieve Sustainable Development at the Southern End of the Americas. Punta Arenas, Chile: Ediciones de la Universidad de Magallanes.

Sagoff, M. (ed.). (1988). The Economy of the Earth: Philosophy, Law, and the Environment. New York: Cambridge Community Press.

Sagoff, M. (1996). On the Value of Endangered and Other Species. Environmental Management 20 (6), 897-911.

Sherriffs, M., Anderson, C., Rozzi, R., \& Zúniga, A. (2004). Explorando la Micro-Biodiversidad del Cabo de Hornos. Guías y Actividades. Fundación Omora. Puerto Williams. Chile. Available at: http://www.omora.org. 
Sugden, R. (2005). Anomalies and Stated Preference Techniques: A framework for a discussion of coping strategies. Environmental \& Resource Economics 32, 1-12.

Thurstone. (1927). The structure of random utility models. Theory and decision 8, 229- 254.

Train, K. (ed.). (2003). Discrete Choice Methods with Simulation. Cambridge: Cambridge University Press.

Turner, K. (1999). The place of economic values in environmental valuation. In: Bateman, J. \& Willis, K. G. (eds.): Valuing Environmental Preferences: Theory and Practice of the Contingent Valuation Method in the US, EU, and Developing Countries (pp. 17-41). Oxford (UK): Oxford University Press.

UNEP (1992). Convention on Biological Diversity. Convention text edited by the Secretariat of the Convention on Biological Diversity.

Available at: http://www.biodiv.org/convention/articles.asp.

Voss, R. (2005). (Eco-/Ethno-) Tourismus auf Navarino Island (Chile). Eine betriebswirtschaftliche Analyse. Diplomarbeit. 6-Monats-Arbeit im Rahmen der Prüfung für Diplom-Kaufleute an der Georg-August-Universität zu Göttingen.

Wilson, M. A. \& Howarth, R. B. (2002). Discourse-Based Valuation of Ecosystem Services: Establishing fair outcomes through group deliberation. Ecological Economics 41, 431-443.

Yachi, S. \& Loreau, M. (1999). Biodiversity and ecosystem productivity in a fluctuating environment : the insurance hypothesis. Proceedings of the National Academy of Sciences of the U. S. A. 96, 1463-1468. 


\title{
CHAPTER IV
}

\section{Trading-off the existence of an endemic moss? - empirical results from a case study at the extreme South of the Americas}

\author{
Claudia Cerda, Jan Barkmann \& Rainer Marggraf
}

\begin{abstract}
The existence value of a species often represents a highly influential motivation for biological conservation. There is an ongoing debate, however, if existence values can be included in economic approaches to conservation planning. In this paper, we first outline the main criticisms to the economic valuation of species existence (isolation of existence value, protest responses, ethical motives/lexicographical preferences), and characterize a novel valuation strategy that takes account of the criticisms. Second, we apply this valuation strategy empirically to an inconspicuous moss endemic to subantarctic Patagonia.

We administered a choice experiment on the biological diversity of Navarino Island (Chile) to a representative sample of local residents $(n=230)$. The design isolates existence value because respondents make simultaneous trade-offs between existence value and five other biodiversity related use values and indirect use values. Navarino residents are willing to trade-off the existence value of the species for a compensation in income of $\sim 69,000 \mathrm{CHP} / \mathrm{month}$ (willingness-to accept compensation; $\mathrm{P}<0.001)$. No conservation-motivated protest responses occurred. All respondents traded-off improvements of the present, non-secured conservation status of the moss at least once. Attitudinal variables operationalizing the value and severity dimensions of Protection Motivation Theory do not explain preferences for the endemic moss, however.

Our choice experiment strategy generated a meaningful marginal value for the existence of an endemic species while avoiding problems related to ill value isolation, protest responses and lexicographic preferences.
\end{abstract}




\section{Introduction}

The existence value of a species often represents a highly influential motivation for biological conservation (Carson et al. 2003). There is an ongoing debate, however, if existence values can be included in economic approaches to conservation planning. Several authors argue it is possible (Loomis 1988, Pearce \& Moran 1994, Carson et al. 2001), and/or desirable to include them (Boyle \& Bishop 1987, Kopp 1992). Others criticize it for several reasons:

a) It is difficult to isolate existence values from other indirect use values (Brookshire et al. 1983, Stoll \& Johnson 1984, Walsh et al. 1984, Loomis 1988).

b) Embedding effects can be particularly severe (Kahneman \& Knetsch 1992).

c) Ethical motives in alledged contradiction to homo economicus the neo-classical economics paradigm (Madariaga \& McConnell 1987, Stevens et al. 1991, Kahneman \& Knetsch 1992).

d) Ethical motives may lead to protest responses and lexicographic preferences (Stevens et al. 1991, Spash \& Hanley 1995, Spash 2000).

In this paper, we do not investigate if it is expedient from a cultural conflict point of view to use economic valuation of existence value (e.g., Rozzi et al. 2001). Instead, we investigate if the above mentioned critiques can be circumvented in a conceptually and empirically coherent way.

In section 2, the basics of economic existence value are introduced. Next, we outline the main criticisms to the economic valuation of species existence (section 3). In section 4, we characterize a valuation strategy that takes account of the criticisms by explicitly subscribing to - and productively using - an exchange value conception of economic value. In section 5, a case study on sustainable development options for Navarino island is presented that applies the suggested valuation strategy. The case study uses a choice experiment approach (Louviere et al. 2000, Bennett \& Blamey 2001, Bateman et al. 2002) for the valuation of a host of biodiversity-related values including the existence value of an inconspicuous moss species endemic to the ecosystems of subantarctic Patagonia. 


\section{Basics of economic existence value}

\subsection{Instrumental and inherent value}

There is general consensus that nature has not only instrumental value but also inherent value (c.f. Marggraf \& Streb 1997). The difference between instrumental and inherent values is whether something should be protected because it is important for something else or because it is (also) valued for itself. If a fact is merely valued because another fact can be valued positively with its help, then the first fact is simply of instrumental value. In all other cases it will also have an inherent value. Let us consider, for example, a walk through the forest. If one takes a walk through the forest because it is the fastest way, then the walk through the forest is of instrumental value. If one takes a walk simply because one feels like it, then it has inherent value. If one takes the walk because one would like to go to the bakery and because one knows how good one feels after one has taken such a walk, then the walk through the forest has both an instrumental value and an inherent value. Notice that instrumental and inherent value are both defined within an anthropocentric framework. ${ }^{1}$

While the term "inherent" value is used for anthropocentric views of the natural environment, the term "intrinsic" value is used for non-anthropocentric views in environmental ethics literature. If someone saves the first tooth his child for years, s/he does not do so with the intention of selling the tooth, or for trading it for something valuable. It does not have an instrumental value; it is of value for its own sake. This value results because this particular tooth is of value to a specific person. Thus, this value is an inherent value. Everything necessary to make a human being's life good or happy has inherent value. Inherent value is the opposite of instrumental value within the anthropocentric scheme of thinking. According to the anthropocentric view, only human beings are members of the moral universe, and all values are derived from human interests. The intrinsic value departs from this framework. If we assign something an intrinsic value, then we do not ask whether anyone believes it to be valuable. The thing itself is the moral subject. Let us return to our example of the lost tooth. There is probably no one who would assign an intrinsic value to his child's tooth. If someone else throws away this tooth, then he has breached his duty towards the person who valued the tooth, not to the tooth itself. This action destroys an inherent value, but not an intrinsic one. The only ones possessing an intrinsic value in this example is the person who

\footnotetext{
${ }^{1}$ With regard to the natural environment non-anthropocentric conceptions of value have to be considered also (see Callicott
} 1989). 
saved the tooth and the child who lost it. The terms "inherent value" and "intrinsic value" help to clarify the anthropocentric issue in the following manner: Is the inherent value of nature only inherent, or is it also of intrinsic value? When the question is posed this way, it is clear that nature not only has an instrumental value for the non-anthropocentrics, but also an inherent value based on the subjectivity of those valuing it. Although directly considering intrinsic values would in deed be foreign of most economic theories, it is economically imperative to account for the intrinsic value motives of non-anthropocentric because these motives influence their economic behaviour.

Accepting the general consensus that, in addition to instrumental values, inherent values of biological diversity are important for an appropriate diversity management, the question is how these inherent values can be taken into account. Attempting to respond this question, economics has proposed the concept of existence value (see below).

\subsection{Existence value}

Usually, environmental economists use the concept of Total Economic Value (TEV) (Pearce 1993, Pearce \& Moran 1994) to classify different values of biological resources. The TEV general classification corresponds to Use Values and Non-Use values. Existence values classifies in the non-use values category.

In economic valuations, non-use values are often decisive. For example, the Exxon Valdez oil spill in Prince William Sound Alaska in 1989 entailed losses of existence value in the order of several billion dollars (Carson et al. 1994). Following the Exxon Valdez oil spill, the attention to estimation techniques for existence values increased sharply abruptly (Carson et al. 2003). Krutilla (1967: 781) introduced the economic concept of existence value four decades ago:

"There are many persons who obtain satisfaction from mere knowledge that part of wilderness North America remains even though they would be appalled by the prospect of being exposed to $i t "$. 
Based on this seminal contribution, several definitions for existence value were put forward (e.g., Hanley \& Spash 1993, Pearce 1993, Lazo et al. 1997, Pearce \& Barbier 2000, Bateman et al. 2002, Millenium Ecosystem Assessment 2003).

While the Total Economic Value (Pearce \& Moran 1994) suggests to include existence values in economic project appraisal, their actual utilisation in cost-benefit analysis is a matter on ongoing and intensive dispute. In following paragraphs, we explain the economic mainstream view of existence value as an exchange value, followed by a brief review of case studies on valuing existence values. From these case studies and related conceptual work, the main criticisms at the inclusion of economic existence value estimates into project appraisal are abstracted (sec. 3).

In the micro-economic foundations of welfare economics, preferences are defined in relation to individual choices on the preferablility of different bundles of goods. Since the so-called "ordinarialist revolution" in economics triggered by Hicks \& Allen (1934), economic value was not related conceptually to some psychological satisfaction measure that humans may derive from consuming a certain measure of a good. Instead, economic value is defined as the exchange relation of one good in relation to other goods. It is often convenient to express economic value as an exchange value in monetary terms. The material justification of this operation can be found in the observation that many people in many situations can be observed to trade-off gains or losses in the provisioning of specific goods by changes in their provisioning with money - i.e. the provisioning with the universe of market goods up for purchase. The application of the exchange value concept does not presuppose the material substitutability of one good by another one. For example, if a particular individual is willing to exchange a litre of water for a half a loaf of bread, it is not presupposed that the bread can actually quench the thirst of that individual. It is economically inferred, however, that the exchange value of half a loaf of bread is at least one litre of water. Exchange value is always an ex ante value. If a specific choice of an exchange transaction is a good choice in a material sense of psychological satisfaction is usually an ex post judgment, however. In face of the dwindling stock of natural resources (see Perrings et al.1995, O'Riordan \& Stoll-Kleeman 2002) and extreme rates of species loss (e.g., Pimm and Lawton 1998), this disregard of the material substitutability of natural capital by human-made capital is one of the 
fundamental problems in mainstream economics that eventually gave rise to the different strains of ecological economics (see Hampicke 1992, Faber et al. 1996). By definition, the existence of a plant or animal species cannot be materially substituted if the species is lost by extinction. It may be the case that some functionally redundant species was present in the affected ecosystem (e.g., McCann 2000), so some substitution by a different element of the natural capital still took place. It is highly unlikely, however, that this functional substitution will be complete. Obviously, a compensation in money for a loss of a species paid to some local stakeholder will not ecologically substitute the species. Still, that stakeholder may accept a certain monetary compensation for the loss of this species. The decision to accept this compensation represents an ex-ante judgement on the subjective substitutability of the existence of that species by an additional availability of market goods.

If the individual

- has no intention ever to make use of that species,

- cannot identify any indirect "ecological" reason why it should be preserved, and

- solely cares for the species by a perception of an ethical duty to preserve the species, the minimum amount of money to be accepted as compensation in a exchange transaction, is a Compensating Variation measure of the existence value of that species (Marggraf \& Streb 1997).

Because existence values cannot be directly observed in any utilisation of the species or inferred from market transactions, Stated Preferences methods are used for their assessment (Freeman 2003). For extensive discussions on the merits and limitations of stated preference methods, we have to refer to sources such as Bateman \& Willis (1999), Bennett \& Blamey (2001), Bateman et al. (2002). Several empirical studies have assessed existence values of wildlife species or of particular ecosystems using different forms of the contingent valuation method. We show some of them in Tab. 1. In Chile, several contingent valuation studies were carried out in protected areas using the CVM method the methodology by Walsh et al. (1984) (De la Maza 1997, Cerda 2003). 
Tab. 1. Case studies attempting to estimate existence values.

Study Topic of valuation

Estimation of value

Boyle \& Bishop (1987) Pure existence value" of the "obscure" striped

4.16 USD/yr/Wisconsin taxshiner (Luxilus chrysocephalus). payer.

$35 \mathrm{USD} / \mathrm{yr} /$ California respondent.
Maximum willingness to pay for the mere ("selfish") knowledge that the ecosystem of Mono Lake (California) continues to exist.
Loomis (1988)

(20)

Stevens et al. (1991)

Existence value of four wildlife species in New England: the wild turkey (Meleagris gallopavo), bald eagle, Atlantic salmon (Salmo salar) and coyote (Carnivorus vulgaris).
For the first two species, average existence values ranged from about 6 to 10 USD/yr/New England mail survey respondent.
Existence value statements for peregrine falcons (Falco peregrinus) and shortnose sturgeons (Acipenser brevirostrum), two endangered species in Maine.
Mean existence value per respondent and year was between 25 and 27 USD per species.

Kotchen \& Reiling (2000)

Existence value for the remaining healthy

Kramer et al. (2002) spruce-fir forests in the southern Appalachian Mountains.
16.24 USD/yr/respondent.

\section{4,500 Chp/yr/visitor.}

Cerda (2003)

\section{Main Criticisms of economic existence values}

Studies such as those outlined above have been subjected to severe criticisms on a number of counts. Focusing on critiques that specifically address problems of the economic valuation of existence values, several criticisms can be abstracted, that are treated in the following subsections. 


\subsection{Isolation/double counting}

The problem to differentiate existence and option values within the non-use benefit categories is a classical topic in the valuation literature for more than two decades (Brookshire et al. 1983, Stoll \& Johnson 1984, Walsh et al. 1984, Loomis 1988, Randall 1999). If existence values are not appropriately isolated, two problems occur: first, there is no proof of the empirical relevance of existence value, and second, there may be the problem of double counting. Double counting occurs because the survey instrument prompts benefit statements for existence values categories that are in fact co-motivated by other value considerations. Often these other value components are already included in cost benefit analyses.

Walsh et al. (1984) proposed one way to differentiate option values and existence values by directly asking respondents to assign their total WTP to different value categories. This methodology was used for example by Loomis (1988), Stevens et al. (1991), De la Maza (1997) and Cerda (2003).

\subsection{Embedding and ill-defined preferences}

Closely related to the problem of isolating existence value, are issues of embedding effects. Embedding effects occur when one environmental good is valued differently when it is included in a bundle of other goods as compared to an individual valuation of the good (Kahnemann \& Knetsch 1992, Dehnhardt \& Meyerhoff 2002). Embedding effects can be particularly severe for existence values: Because there is no difference in users benefits if the existence value of one or 1,000 species is preserved, there is a particular risk that respondents disregard the quantity information provided in valuation scenarios. Furthermore, because respondents have not made any use of species with exclusive existence value, their preferences may be ill-defined; particularly in case of an obscure species they may not even have heard about before. Precisely because of the often "ethical" character of existence values, it appears plausible that existence value goods display an extremely fast declining marginal unit value.

More severe is a suggestion by Kahneman and Knetsch that survey respondents are not motivated at all by the presented information of the existence value good but state preferences only to experience the "warm glow of giving". While some authors agree with this suggestion (Nunes \& 
Schokkaert 2001), others dispute its validity (Hanemann 1994, 1996, Carson et al. 2001).

\subsection{Motives in contradiction of selfishness}

Ethical concerns or altruism have been shown to be the main motives of many respondents to give positive bids in a Contingent Valuation survey (Madariaga \& McConnell 1987, Sagoff 1988, Stevens et al. 1991, Kahneman \& Knetsch 1992). Sagoff (1996) argues that people have moral principles regarding their responsibility to rescue endangered species. Therefore statements in CV surveys are not an expression of preference related to one's own welfare or well-being. People who believe that extinction is wrong may simply be willing to pay a fair share to rescue a species. Consequently, the responses are thought to be incompatible with neoclassical assumptions on selfish behaviour of economic actors. The question is if "motives matter" (Madariaga \& McConnell 1987, Edwards 1992, Spash \& Hanley 1995, Spash 2000) or if they do not .

\subsection{Lexicographic preferences}

Preference statements motivated by ethical reasons can lead to lexicographic preferences (Edwards 1986, 1992, Stevens et al. 1991, Spash \& Hanley 1995, Spash 2000). If an individual believes that aspects of the environment such as wildlife, have an absolute right to be protected, then that individual will refuse all monetary trade-offs which decrease what is regarded as an environmental commodity in the neoclassical framework (Spash \& Hanley 1995). If this was actually the case, no monetary value could be ascribed to species existence; the preferences are "ill-behaved" from a neo-classical point of view. This need not be the case, however. Kramer et al. (2002) found, for example, that consumer preferences regarding the existence of certain forest ecosystems were "well behaved" and consistent with the axioms of economic theory.

\subsection{Protests responses}

A study of Stevens et al. (1991), revealed that $80 \%$ of survey respondents said that bald eagles (Haliaeetus leucocephalus), wild turkey (Meleagris gallopavo) and Atlantic salmon (Salmo salar) are important to them. When confronted with a WTP question, the majority refused to pay. $40 \%$ of respondents protested the payment vehicle arguing that wildlife should not be valued in monetary terms. The authors argue that CVM may fail in providing a valid measure of existence 
values. Ethically motivated protest behaviour is not universal, however. Kotchen \& Reiling (2000) found that respondents with stronger environmental attitudes are more likely to participate in the valuation procedure despite higher importance they ascribe to ethically based motivations.

\section{Consistent quantification strategy using a choice experiment}

Recent advances in environmental valuation research hold some promise to overcome the problems addressed in the previous section. Choice experiments (CE) were developed originally for marketing and transport applications (Louviere \& Hensher 1982, Louviere \& Woodworth 1983). For recent introductory texts, see Bateman et al. (2002) and Hensher et al. (2005). During the past decade, CEs have increasingly been applied to environmental valuation tasks (e.g., Adamovicz et al. 1994, 1998, Boxall et al. 1996, Hanley et al. 1998, Othman 2004, Colombo et al. 2005).

In choice experiments, respondents are asked to choose one from usually three development or conservation options that differ in several characteristics (attributes). For economically quantifying existence value, one of the attributes represents species existence, one represents a change in the available income position of the respondents (c.f. Bateman et al. 2002, Pearce \& Özdemiroglu 2002). The attributes take two to several different levels (e.g., species continues to exist: yes/no; cost: 5/10/15/20 EUR* $\mathrm{yr}^{-1}$ ). As development and conservation programs often have more than one economically, ecologically or socially relevant effect, such effects are included by additional attributes.

In most CE surveys, respondents are confronted with three "options" or "scenarios" to choose. The three options are formed from different combinations of the attribute levels. The third option represents the current state of the environment and of respondent income (status quo). The status quo option is included to ensure the welfare economic interpretability of results (Hanley \& Mourato 2001, Bennett \& Blamey 2001). Respondents are now asked which of the options they prefer and like to see implemented.

Statistical models derived from Random Utility Theory (RUT) (McFadden 1973) predict choice behaviour as a function of the attribute levels that characterize the options. By an analysis of the 
choice patterns among the options, the relative influence of the attributes on choices can be inferred, and marginal WTP/WTA values for an increase or decrease in significant attributes calculated (Hanley et al. 1998). This last step is conducted for linear utility functions by dividing the attribute coefficients of the environmental attribute by the coefficient of the monetary attribute. The trade-off estimated is known as a part-worth or "implicit price" when calculated for a marginal unit of the environmental attribute (Bennett \& Adamowicz 2001). For cost-benefit analysis, the implicit price is multiplied by the scenario changes relative to the status quo to obtain the compensating variation measure of the scenario change.

Choice experiments are based on confronting respondents with exchange or trade-off situations that are similar to the choices required in real-world decision-making processes. In classical Contingent Valuation (CV) surveys, respondents are more or less directly asked how much money they are willing to pay (or accept as compensation) for a change in their provision with environmental goods such as species existence. Under many circumstances, the CV questions appear as highly artificial, because respondents are not used to be confronted with such questions - neither in their roles as consumers nor as citizens. Although the specific choice experiment format (see Fig. 3) is unusual for most respondents as well, the basic problem to find the best combination of advantages and disadvantages of different courses of action is well-known to most respondents, however. This also holds for the public discussion on development and conservation projects. In most cases, different variants with different sets of advantages and disadvantages are under discussion. Furthermore, it is quite plausible to respondents that local or regional taxes may - or may not - change as a result of the implementation of the projects. In essence, choice experiments capture part of the multi-criterial complexity of real-world decision-making processes. Because an artificially isolated - and in this form ethically problematic - WPT or WTA question is avoided, the rate of strong protest responses (rejection of the choice task) are expected to be lower than in CV studies (c.f. Pearce \& Özdemiroglu 2002, Bateman et al. 2002: 276).

Choice experiments have additional advantages with regard to lexicographic preferences. In choice experiments, more than just two dichotomous attribute levels, such as "moss species extinct" versus "moss species not extinct", can be applied. We capitalize on this opportunity by using three levels for moss extinction. The status quo is described as "moss exists on Navarino, 
but its Navarino habitats are not secured (low level of extinction)". The improved situation as "moss exists on Navarino, and Navarino habitats are secured (very low level of extinction)"; the disimproved situation as "moss does not exist on Navarino any more (increased level of extinction)". The implicit thinking in extinction probabilities that underlies the attribute levels should reduce lexicographic response behavior. Again, this set up allows for additional realism, this time from a conservation biological point of view.

Next, the measurement strategy must deal with the critique that embedding effects may be particularly high because of ill-defined preferences. For the case study documented in the next section, we choose to present respondents with a moss species explained to be endemic to the region where the case study was conducted. We did not identify the moss (Fig. 1) botanically but made sure that respondents were aware of what a moss species is and understood what endemic means. While respondents certainly did not have specific preferences for the existence of the specific species Tayloria mirabilis (Fig. 1), they had preferences for the protection of an otherwise obscure tiny plant species whose habitat is restricted to subantarctic Patagonia. This description directly relates to the embedding effect. We assume that the generated compensating variation value for the existence of the moss species does, in fact, represent the main share of the total compensating variation for the existence value of all obscure species by the inquired Chilean respondents. As a consequence, the generated existence value lost does not change in cost-benefit analysis, no matter, if one or more obscure species go extinct. This is what we call a "constructive" use of embedding effect. 


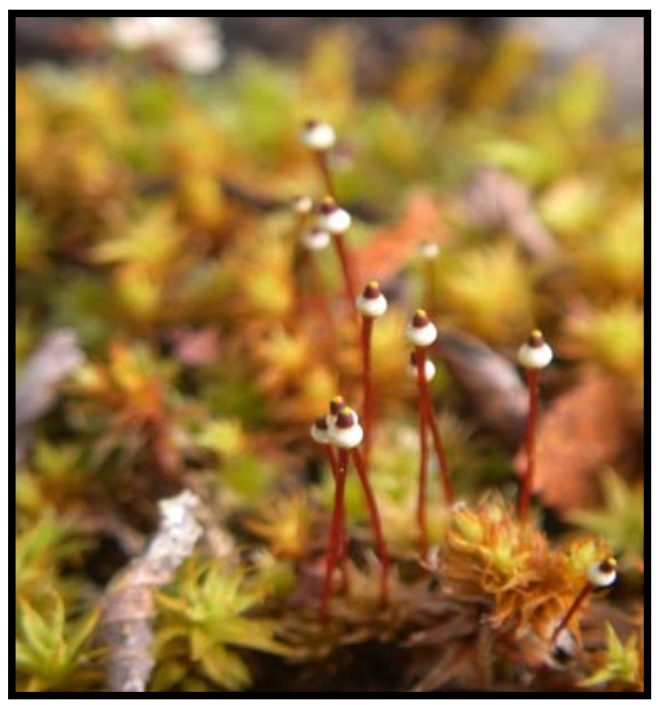

Fig. 1. An endemic moss of the subanctarctic forests: Tayloria mirabilis.

(Photograph Silvina Ippi. Omora Ethnobotanical Park photoarchive).

Finally, the choice experiment must assure that the existence value is sufficiently isolated from other value categories that may be associated with the moss. Here we applied two methods. First, we checked in a pre-study that respondents cannot name any specific use or usefulness of the moss (Fig. 2). Second, we included three other attributes in the choice experiment that refer to species aesthetics, the ethno-cultural value of species, and to the ecological insurance value of species richness. Thus, respondents interested in these value categories that potentially apply to the moss species were confronted with much more direct ways to express their preferences for such qualities. In combination, these two steps were expected to isolate existence value effectively.

\section{Case study: Economic existence value of a subanctartic endemic moss in southern Chile}

\subsection{Study area}

The island of Navarino is located at the extreme south of America (Comuna Cabo de Hornos). It has about 2,000 citizens mainly employed by the Chilean Navy, public administration and the fishing industry. This island harbours one of the few not fragmented temperate forests ecosystems globally. The ecological impact of agricultural and tourist activity is low at present (Cerda et al. 2005). However, intensified tourism development could affect ecosystem function and species composition (Jax 2003). The Magellanic sub-Anctarctic region, includes the most diverse 
non-vascular flora in Chile, and is a hotspot for bryophyte diversity. The region contains more than 750 species of mosses and liverworts (5\% of the global bryophyte diversity; Rozzi et al. 2004). The Chilean NGO Fundación Omora initiated educational activities to foster knowledge on moss diversity (Sherriffs et al. 2004). In 2005, Navarino island and the two adjacent national parks were declared UNESCO Biosphere reserves.

\subsection{Methodology}

The careful investigation of patterns of respondent perception of the natural environment is an indispensable component of any Stated Preference study (Arrow et al. 1993, Barkmann et al. 2005). These aspects are explained in the following subsections.

\subsubsection{Pre-study an instrument design}

We intended to assess existence value using an "obscure" species (e.g., Boyle \& Bishop 1987). Because of the importance of the moss flora of Navarino, we chose a moss species endemic to the subantarctic forests of southern Patagonia. One such endemic species is Tayloria mirabilis (Fig. 1). Deliberately, we chosed to focus on a single species because strong embedding effects appeared likely (sec. 4).

\subsubsection{Perception of mosses}

Local species such as the Magellanic Woodpecker (Camphepilus Magellanicus), the King Crab (Lithodes santolla) or the Southern Beaches (Nothofagus spp.) are known by Navarino respondents to provide direct aesthetic and production services (e.g., Arango \& Rozzi 2005). For a successful utilisation of an endemic moss species as a CE attribute operationalising existence value, it is necessary that respondents know what mosses are, but they should not be able to attribute any specific direct use or indirect use value to it. To test this qualitatively, 54 interviews were carried out with local residents. We used semi-structured questionnaires in collaboration with other researchers of the project to identify pre-theoretic cognitions on nature and the humannature relation ("images of nature" analysis, Barkmann et al. 2005). 14 interviews were immediately transcripted and analysed (Fig. 2). Attention and knowledge of respondents was focused on a small number of species and ecosystem services with direct links to human utilisation. No re- 
spondent mentioned "mosses" spontaneously as a known or preferred type of plant. On the other hand, all respondents stated to know that mosses exist on the island when explicitly asked. Two respondents (one of them with a - locally rare - academic background in biology) assigned ecological importance to the mosses for soil formation. Results of the 14 interviews were crosschecked with field notes and tape recordings of the other 40 interviews (c.f. Berghöfer 2005). The cross-check supported the notion that residents are sufficiently aware of the mosses on the island without ascribing any specific direct or indirect use value to them.

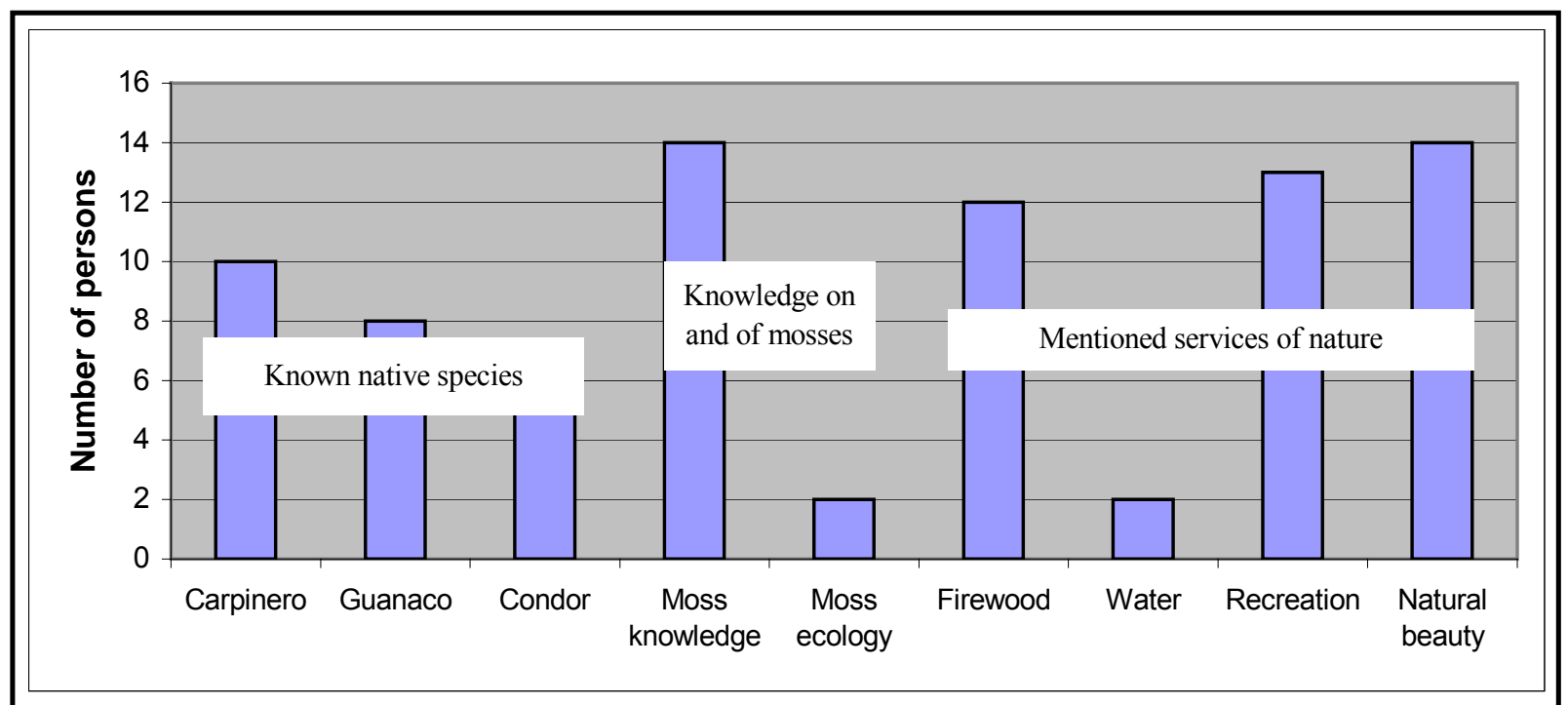

Fig 2: Example from a sub-sample of the images of nature analysis $(n=14)$.

Source: Cerda et al. 2005.

\subsubsection{Construction of the moss attribute to assess existence value}

We tried to estimate the compensating variation for changes in qualitatively described extinction probabilities of a moss species endemic of subanctartic Patagonia. The moss was explained to rely for its continued survival on its habitat in Navarino Island. The existence value attribute had three levels: (i) increased probability of extinction, (ii) low probability of extinction which corresponds to the actual situation, and (iii) very low probability of extinction because of specific protection measures.

In formulating the explanation, specific care was taken to account for the fact that no moss species is known to be strictly endemic to Navarino island. Because of the dispersal mechanisms of mosses and the proximity of Navarino to other Patagonian islands including Isla Grande de Tierra 
del Fuego, it is also unlikely that strict endemism occurs. Second, we had to minimise the risk that respondents perceive the suggested protection measures as either an impediment to economic development or as an additional protection for other species, ecosystems or ecosystem services. Thus, we point out that the protected sites are "small" only, and directly protect the moss habitat only.

Because of its importance for the evaluation of the results, we reproduce a part of the explanation of the attribute an its levels here in an English translation:

"Scientists call a moss that lives only in this zone "endemic moss". "Endemic" means that the moss only exists in one place of the world. If eventually one of the endemic mosses disappeared from Navarino, which is an important part of its habitat, the probability that the moss disappears from the whole Subanctarctic zone increases. Because this moss is endemic of this zone, it would mean that it would disappear from the entire world and would go completely extinct. [...] Imagine two cases:

First: Some activities on the island of Navarino destroy, by accident, all places where the moss lives. Thus, the moss loses an important part of its life space. Consequently the moss can go extinct easily from its entire place of life in the Subanctarctic zone. The probability of extinction would increase. [...]

Second: A few small areas are established on Navarino to protect specifically the life spaces of the moss. Then, in spite of some development activities, the moss continues to exist in all its life spaces on the island. Under these circumstances, the probability that the endemic moss goes extinct is very low because its important life places would be better protected than now of accidental damages."

\subsubsection{Attitudinal items and socio-demographic variables}

It is a standard procedure in stated preference studies to include attitudinal questions (i) to explain individual preference variations, and (ii) to relate preferences to underlying respondent values in order to support the validity of results generated from - hypothetical - stated preference surveys (Bateman et al. 2002). We developed several attitudinal questions for all attributes based on Protection Motivation Theory (PMT; Rogers \& Prentice-Dunn 1997). PMT explains behaviour in the 
face of "risk" based on subjective attitudes, such as risk and related value perceptions as well as respective coping appraisals. PMT variables had been found to have significant explanatory effects on WTP for biological diversity (Menzel 2003) and ecosystem services (Barkmann et al. 2006). In the main study, we included two PMT items on the "values" and "severity" categories of PMT (4-point Likert scale):

- The existence of the endemic moss is important to me. (value)

- An increased probability that the endemic moss disappears is a big problem for nature. (severity)

Additionally we asked an open question to obtain direct insight into the motivations of the respondents:

Some people think: It is bad if the endemic moss disappears, some do not care. What is your opinion and why?

Construct validity (c.f. Bateman et al. 2002: 340) would be supported if the qualitative variables (a) explain preference variations conforming with social-psychological theory. Also validity would be supported if (b) a statistically significant WTA value can be documented for respondents with clear qualitative non-use value motivations.

Additionally, socio-demographic variables such as income, education level, occupation, children, sex and age were asked to the respondents and included into analysis.

\subsubsection{Construction of CE instrument}

Using the outputs from the multidisciplinary images of nature analysis (Barkmann et al. 2005), several relevant biodiversity-related goods and services were identified and included as attributes. In order to achieve an effective isolation of the single attributes, we included examples from all non-market categories of the Total Economic Value (TEV). The environmental attributes were:

1 aesthetic quality of the landscape (direct use value),

2 free access to nature/the landscape (direct use value), 
3 possibility to see three of the most favoured animals more - or less - often (direct use value),

4 continued visit of the hummingbirds related to the indigenous Yagan culture (ethnosymbolic value),

5 health, resistance and vigour of nature indicated by local species richness, and

6 probability of extinction of an endemic moss (existence value).

With exception of the attribute related to ecosystem health, all attributes came up spontaneously in the qualitative interviews. The health, resistance and vigor of nature attribute was employed to introduce a long-term indirect use perspective on biological diversity to the valuation exercise in the sense of the ecological insurance hypothesis (Yachi \& Loreau 1999). The language follows functional descriptions of ecosystem health, in which the vigor and resilience of ecological systems are stressed (Costanza et al. 1992). For further details, see Kutsch et al. (2001), Barkmann \& Marggraf (2004). Because of the relative openness of the planning situation, attributes levels were designed as improvements as well as disimprovements of the current situations (see Tab. 2) (see also Cerda et al. 2006, this thesis).

As a payment vehicle, we used positive and negative changes in income. We included three increases in income - i.e. the willingness-to-accept compensation (WTA) format - versus one decrease in income because most actually contemplated 'sustainable' development options for Navarino are likely to result in additional damage to the biological diversity on the island. Additionally, declines in biodiversity can be interpreted as a loss in a factual property rights position of the local residents who enjoy only little restricted access to most of the island.

A pilot study ( $\mathrm{n}=45)$ was carried out during April and May 2004. There were zero protest responses during the application of the pilot questionnaire. The results indicated that the continued existence of an endemic moss may be an important part of the total compensating variation for changes in the included attributes. 
Tab. 2: Attributes and levels used in choice experiment .

\begin{tabular}{|c|c|c|}
\hline $\begin{array}{r}\text { Valuation } \\
\text { dimension } \\
\end{array}$ & Attribute & $\begin{array}{l}\text { Levels } \\
\text { (coding) } \\
\end{array}$ \\
\hline $\begin{array}{l}\text { Aesthetic } \\
\text { quality of } \\
\text { landscape }\end{array}$ & $\begin{array}{l}\text { Change on landscape by impact of } \\
\text { tourist infrastructure }\end{array}$ & $\begin{array}{l}\text { Very small change }(-1)^{*} \\
\text { Small change }(+1) \\
\text { Medium change }(+1) \\
\text { Big change }(-2)\end{array}$ \\
\hline Access $^{\S}$ & $\begin{array}{l}\text { Access restrictions to nature by pri- } \\
\text { vate interests } \\
\text { Access restrictions to nature by con- } \\
\text { servation interests }\end{array}$ & $\begin{array}{l}\text { Not restricted*(1) } \\
\text { Medium restrictions (2) } \\
\text { Very restricted (3) }\end{array}$ \\
\hline $\begin{array}{l}\text { Aesthetic } \\
\text { value }\end{array}$ & $\begin{array}{l}\text { Possibility to see animals } \\
\text { (carpinteros, guanacos, cóndores) }\end{array}$ & $\begin{array}{l}25 \% \text { more than now }(1) \\
\text { as now }(2)^{*} \\
25 \% \text { less than now }(-2)\end{array}$ \\
\hline $\begin{array}{l}\text { Ethno } \\
\text { symbolic } \\
\text { value }\end{array}$ & The hummingbirds visit Navarino & $\begin{array}{l}\text { They do not come to the island anymore }(-1) \\
\text { Not secure visit* }(0) \\
\text { Secure visit }(+1)\end{array}$ \\
\hline $\begin{array}{l}\text { Existence } \\
\text { value }\end{array}$ & $\begin{array}{l}\text { Probability of extinction of an en- } \\
\text { demic moss }\end{array}$ & $\begin{array}{l}\text { Increased probability }(-1) \\
\text { Low probability }(+1)^{*} \\
\text { Very low probability }(+1)\end{array}$ \\
\hline $\begin{array}{l}\text { Ecosystem } \\
\text { "health" }\end{array}$ & $\begin{array}{l}\text { Number of types }{ }^{\text {s }} \text { of animals and } \\
\text { plants indicating the "health, resis- } \\
\text { tance and vigour of nature" }\end{array}$ & $\begin{array}{l}400 \text { types ("low health, vigour and resistance") } \\
800 \text { types ("medium...") } \\
1.600 \text { types ("high ...")* }\end{array}$ \\
\hline $\begin{array}{l}\text { Payment } \\
\text { vehicle }\end{array}$ & Monthly income change & $\begin{array}{l}-\$ 30.000 \text { Chilean pesos } \\
\$ 0 \text { Chilean pesos* } \\
+20.000 \text { Chilean pesos } \\
+30.000 \text { Chilean pesos } \\
+40.000 \text { Chilean pesos } \\
\end{array}$ \\
\hline
\end{tabular}

* Status Quo level; ${ }^{\S}$ a split sample differentiating access restrictions caused by private economic activities versus conservation projects; $\$$ in the questionnaire, we used "types" (typos) instead of the more technical term "species" (especies) in order to reduce the cognitive burden of the respondents; $100 \mathrm{CHP} \sim 0.13$ Euro at the time of the main study.

For the main study, we generated a reduced orthogonal design (Louviere et al. 2000) with 32 different options, which were combined into choice sets with options A and B and one status quo option. The options were assigned in four blocks of 8 choices each. One of the blocks was randomly assigned to each respondent. Fig. 3 shows an example of one set of choice. 
Fig. 3: Example of a choice set.

\begin{tabular}{l|l|l|l}
\hline \hline \multicolumn{1}{c|}{ Attributes } & \multicolumn{1}{c|}{ Option A } & \multicolumn{1}{c|}{ Option B } & \multicolumn{1}{c}{ Status Quo } \\
\hline $\begin{array}{l}\text { Change on landscape by impact } \\
\text { of tourist infrastructure }\end{array}$ & Small change & Big change & Very small change \\
\hline Income change/month & $\$ 0 /$ month & $+\$ 30.000 /$ month & $\$ 0 /$ month \\
\hline $\begin{array}{l}\text { Number of types of animals } \\
\text { and plants }\end{array}$ & $\begin{array}{l}\text { 1600: Good health, } \\
\text { resistance and vigour } \\
\text { of nature }\end{array}$ & $\begin{array}{l}800: \text { Middle health, } \\
\text { resistance and vigour } \\
\text { of nature }\end{array}$ & $\begin{array}{l}1600: \text { Good health, } \\
\text { resistance and vigour } \\
\text { of nature }\end{array}$ \\
\hline $\begin{array}{l}\text { Possibility to see animals } \\
\text { (carpinteros, guanacos and cón- } \\
\text { dores) }\end{array}$ & See as often as now & $\begin{array}{l}\text { See } 25 \% \text { more often } \\
\text { than now }\end{array}$ & As often as now \\
\hline $\begin{array}{l}\text { Probability of extinction of an } \\
\text { endemic moss }\end{array}$ & Increased & It is very low & It is low \\
\hline $\begin{array}{l}\text { Access restrictions to nature } \\
\text { for private or conservation con- } \\
\text { cerns) }\end{array}$ & Some restrictions & Severe restrictions & No restrictions \\
\hline $\begin{array}{l}\text { The hummingbirds visit the } \\
\text { island }\end{array}$ & $\begin{array}{l}\text { They do not come to } \\
\text { the island anymore }\end{array}$ & Not secure visit & Not secure visit \\
\hline \hline
\end{tabular}

\subsubsection{Administration of the main study}

A stratified sample of residents of Navarino island was interviewed face-to-face by the first author of this paper and two well-trained assistants from January to April 2005 ( $\mathrm{n}=235)$. To correct for stratification biases; different economic activities as used by the Chilean National Census (INE 2002) were employed as stratification criteria. Full randomisation could not be achieved as recruiting respondents from groups such as fishermen and construction workers within a very small community required some snow-ball sampling.

The CE instrument contained five parts. First, an introductory section explained the purpose of the choice experiment as an instrument to inform decision-makers on Navarino residents' views on development and conservation of the island. In the second section, the attributes and attribute levels were introduced. Each attribute was exhaustively explained to respondents; open questions on some attributes were asked. The choice sets were presented to the respondents in the third phase of the interview. The two last parts contained PMT and socio demographic questions. 


\subsubsection{Data analysis}

\subsubsection{Qualitative analysis}

Responses to the open question regarding moss existence (see sec. 5.2.1.3), were analysed by a word count of several answer categories developed inductively from the interview material (see Tab. 3 in sec. 6.1). Two general categories were formed: Care and No-care. Care indicates that the respondent states that $\mathrm{s} / \mathrm{he}$ cares about the probability of moss extinction; No-care that $\mathrm{s} / \mathrm{he}$ does not. For those who care, two subcategories were created. If statements use an existence value argumentation, the respondent was assigned to an existence value group. In the classification, priority was given to spontaneous answers.

\subsubsection{Econometric analysis}

Preliminary data analyses had shown that the landscape change attribute as well as the species aesthetics attribute did not become significant predictors of choice when attribute levels were coded assuming linear utility functions. Because the pre-study interviews had strongly suggested an influence, we examined the functional form of the utility function. In both cases, statistical performance of models with dummy-coded attribute levels indicated an inverted U-shaped utility function. The coding was adjusted accordingly, and used for model construction (see Tab. 2). The functional form of the utility function of the moss attribute was also examined using dummycoded attribute levels. No big differences between the coefficients of current and improved level of moss protection was found. The coding was adjusted (see Tab. 2) and used for model estimation.

Because violations of the IIA condition had been observed for several multinomial logit models generated from the data set, we consistently apply Nested Logit (NL) procedures that do not presuppose the IIA property (see Hensher et al. 2005). The Inclusive Value of the degenerated branch was set to 1.0 (Hensher et al. 2005: 570). Scale parameters were normalized at the lowest level (RU1; Hensher et al. 2005: 538). We selected the best fitting tree structure with an IV value between zero and 1 (Hensher et al. 2005: 494). Two sets of NL choice models were estimated. The first set includes all participants of the study. A second 'restricted' set of models includes 
only those respondents whose statements on the open attitude question on moss existence (see sec. 5.2.1.3) implied an existence value motivation.

A weighting factor for each respondent observation was included to take account of stratification sampling bias. An alternative specific constant (ASC) was coded 1 for the non-status quo options $\mathrm{A}$ and $\mathrm{B}$, and 0 for the status quo option. Seven socio-economic variables (age, sex, income, respondent has children, years of education, time on the island, time in the future) were introduced into the NL models as interactions with the ASC to test their influence on choice, and were accordingly included in the final models.

The two attitudinal PMT items on moss existence were introduced as interactions with the moss attribute into NL models (Tab. 5 (b) and (c); Tab. 6 (b) and (c)). Because of likely collinearity between the two interaction variables and the moss attribute, we calculated three otherwise identically specified models to test for their influence on choice for each set of models.

Implicit prices (= compensation variation for a marginal change of attribute levels) are calculated as marginal WTA as suggested by the dominant WTA choice format. According to our coding scheme (Tab. 2), a marginal unit of change in the probability of moss extinction is defined (i) as the transition from a present but unsecured to a secured status of the endemic moss populations on Navarino island, or (ii) as the transition from the current "low probability of extinction" to a highly threatened status where the important populations on Navarino island are destroyed. Thus, a base situation was required for calculation of implicit prices. This corresponded to the Status Quo level. In particular, we divided the NL coefficient of the moss existence attribute by the coefficient of the monetary attribute. This resultant value was multiplied by the corresponding "marginal" step. The steps represent a change from the status quo level to an adjacent attribute level. Implicit prices are given for the best fitting models only. 


\section{Empirical Results}

From a total of 235 participants, two respondents quit the interview in an early phase because they perceive the interview as too pro-environmental. Three respondents lacked understanding of the CE procedure. Analyses are based on the remaining 230 respondents. Ten respondents declined to answer the PMT attitudinal questions, mainly because of lacking time. These missing values were substituted by mean values of the respective variables.

\subsection{Background analysis}

Regarding the open attitudinal question (see sec. 5.2.1.3), 198 respondents (86\%) expressed a concern for moss existence on Navarino (Tab. 3). 32 respondents (14\%) did not care for moss existence arguing that the moss species has no known use or usefulness. Four justification categories were classified as indicating an existence value argumentation. The arguments "it is unique, endemic", "it has to be valued and protected", "it is part of nature" and "rights of existence" are related to existence value. "It is unique, endemic" seems to be related to what Krutilla had in mind in 1967 as he argued that irreversibility and uniqueness were both essential for existence value. Also Madariaga and McConell (1987) express that existence value is likely to be most important for environmental assets that are unique, irreplaceable, and long-lived. The category "It has to be valued and protected" comprises answers with a sense of moral obligation of the community of Navarino to protect the moss species. "It is part of nature" refers to an ethically charged perspective on the natural world beyond self-interest. Two participants argued that the moss has the same right of existence - again an ethically motivated justification.

Six categories indicate other motivations than existence values or represent ambiguous categories. The moss "exists for some unknown reason" implied that respondents thought it was not a good idea to destroy its habitats because it may turn out to be important or useful after some more investigations. So the answers relate to an option or quasi-option value. "Because I love nature" may be related to existence values. It can be interpreted in rather selfish terms as well, however. The arguments "ecological importance", "important for tourism", "important for science" and "scenic value" clearly comprise direct and indirect use values. Several of the explanations were 
similar to the arguments that the local NGO, Omora Foundation, uses in its educational activities on bryophyte diversity on Navarino. For four respondents, the moss has a bequest value. All of them argued "I want that my children and grandchildren see this moss". Although bequest values are non-use values as are existence values, we chose not to include this category in the existence value group to avoid ambiguous cases.

Tab. 3. Statements about the probability of extinction of an endemic moss $(n=230)$.

\begin{tabular}{|c|c|c|c|c|}
\hline & Values & Reasons & $\begin{array}{c}\text { Number of } \\
\text { responses }\end{array}$ & $\%$ of total \\
\hline \multirow{9}{*}{ CARE } & \multirow{3}{*}{$\begin{array}{l}\text { Existence } \\
\text { Value } \\
(\mathrm{n}=96)\end{array}$} & It is unique, endemic & 76 & \multirow{3}{*}{$42 \%$} \\
\hline & & Because it has to be valued and protected & 8 & \\
\hline & & It is part of nature, has right of existence & 12 & \\
\hline & \multirow{6}{*}{$\begin{array}{l}\text { Other values } \\
(n=102)\end{array}$} & Ecological importance & 32 & \multirow{6}{*}{$44 \%$} \\
\hline & & It exists for some unknown reason & 31 & \\
\hline & & $\begin{array}{l}\text { It is important for tourism, has scenic } \\
\text { value }\end{array}$ & 23 & \\
\hline & & It is important for science & 8 & \\
\hline & & Future generations & 4 & \\
\hline & & Because I love nature & 4 & \\
\hline \multicolumn{2}{|c|}{ NOCARE } & I do not know any benefit & 32 & $14 \%$ \\
\hline
\end{tabular}

\subsection{Nested Logit Model estimations}

In this section, results of Nested Logit Models performances are shown. A summary of the mean of PMT and socio-demographic variables of the remaining 230 respondents as well as of the existence value motivated respondents is given in Table 4 . We only show variables used later for analysis. 
Tab. 4. Definition of PMT attitudinal and socio-demographic variables.

\begin{tabular}{llcc}
\hline \hline Variable & Description & \multicolumn{1}{c}{$\begin{array}{c}\text { All } \\
\text { respondents } \\
(\mathbf{n = 2 3 0 )}\end{array}$} & $\begin{array}{c}\text { Sub-sample } \\
\text { existence value } \\
\text { motivation } \\
(\mathbf{n = 9 6 )}\end{array}$ \\
\hline \hline Moss value & $\begin{array}{l}\text { Numerical variable indicating importance of } \\
\text { moss existence for the respondents } \\
\text { (Likert-scale) }\end{array}$ & 3,00 & 3,10 \\
\hline Moss severity & $\begin{array}{l}\text { Numerical variable indicating severity of moss } \\
\text { extinction for the respondents } \\
\text { (Likert-scale) }\end{array}$ & 2,94 & 3,06 \\
\hline Education & Number of years of education of the respondent & 12,8 & 12,8 \\
\hline \hline
\end{tabular}

\subsubsection{Nested logit models: all respondents}

All three models are overall significant with $\mathrm{P}<0.0001$. Adjusted Pseudo- $\mathrm{R}^{2}$ values vary only minimally between 0.2190 and 0.2197 ; the value of the log-likelihood function indicates marginally better fit of model (a). With the exception of the possibility to see three animals, all included terms are significant at $\mathrm{P} \leq 0.5$. For all linear environmental attributes (access restrictions for private and conservation concerns, visits of hummingbirds and ecosystem health), the signs of the coefficients are positive indicating that more of the attribute does, on average, increase the probability of an option being chosen. For the non-linear landscape change attribute, the sign of the coefficient is positive as expected because of the coding used (see Tab. 2). The sign of the monetary attribute is positive as expected for a WTA instrument format. The ASC*Education coefficient shows that more years of education result in a decreased attractivity of the offered changes versus the status quo.

The coefficients of the three moss existence value terms are highly significant and positive as expected. When the raw coefficients of the interaction terms are multiplied with sample means of the interacted variables, coefficients are similar; model (a): $0.2301(\mathrm{P}<0.001)$, model (b): 0.2070 $(\mathrm{P}<0.001)$, and model (c): $0.2056(\mathrm{P}<0.001)$. 
Tab. 5. All-Respondents Models.

\begin{tabular}{|c|c|c|c|}
\hline Variable & $\begin{array}{c}\text { (a) } \\
\text { Non-Interacted Terms }\end{array}$ & $\begin{array}{c}\text { (b) } \\
\text { Interaction } \\
\text { moss*moss value }\end{array}$ & $\begin{array}{c}(c) \\
\text { Interaction } \\
\text { moss*moss severity }\end{array}$ \\
\hline Landscape Change & $0.0999 * *$ & $0.0993^{* *}$ & $0.0996^{* *}$ \\
\hline Access Restrictions (private) ${ }^{\varsigma}$ & $0.1485^{* * *}$ & $0.1465^{* * *}$ & $0.1477^{* * *}$ \\
\hline Access Restrictions (conservation) ${ }^{s}$ & $\odot .1069 * *$ & $0.1005^{* *}$ & $0.1000^{* *}$ \\
\hline Possibility to see three species & $0.0213^{(n s)}$ & $\odot .0209^{(n s)}$ & $0.0276^{(n s)}$ \\
\hline $\begin{array}{l}\text { Visits of hummingbirds with } \\
\text { ethno-symbolic value }\end{array}$ & $0.5773^{* * *}$ & $0.5761^{* * *}$ & $0.5740 * * *$ \\
\hline Ecosystem Health & $0.0007^{* * *}$ & $0.0006^{* * *}$ & $0.0006^{* * *}$ \\
\hline \multicolumn{4}{|l|}{ Moss existence } \\
\hline Non-interacted term & $0.2301 * * *$ & - & - \\
\hline Interaction with value[mean $]^{\$}$ & - & $\odot .2070^{* * *}$ & - \\
\hline Interaction with severity[mean $]^{\$}$ & - & - & $0.2056 * * *$ \\
\hline Income Change $^{\S}$ & $0.0067 * * *$ & $0.0066 * * *$ & $0.0067 * \star *$ \\
\hline ASC*Education $^{\$}$ & $-\odot .3648 * * *$ & $-\odot .3759 * * *$ & $-\odot .3741^{* * *}$ \\
\hline Log-likelihood & -1641.26 & -1542.54 & -1642.81 \\
\hline Restricted Log-likelihood & -2109.17 & -2109.17 & -2109.17 \\
\hline $\mathrm{P}\left(\mathrm{Chi}^{2}\right) ; \mathrm{DF}$ & $<0.0001 ; 10$ & $<\odot .0 \odot \odot 1 ; 10$ & $<0.0001 ; 10$ \\
\hline Inclusive value (IV) & $\odot .9842$ & 0.9854 & $\odot .9854$ \\
\hline Adj. $\rho^{2}$ (Pseudo- $\left.R^{2}\right)$ & $\odot .2197$ & 0.2191 & 0.2190 \\
\hline
\end{tabular}

***: significant at $\mathrm{p} \leq 0.001 ; * *$ : significant at $\mathrm{p} \leq 0.01 ; *$ : significant at $\mathrm{p} \leq 0.05 ;{ }^{\text {\$ }}$ raw coefficients multiplied with the sample means (see Tab. 4); ${ }^{\S}$ cost coefficient for $1,000 \mathrm{CHP} / \mathrm{yr}$ /household; DF: degrees of freedom; ${ }^{\#}$ all IV statistics are highly significantly different from 0 ; Nested Logit models based on 230 respondents with 8 choices each: $n=8 * 230=1840$ observations.

\subsubsection{Nested Logit models II (sub-sample with explicit existence value motivation)}

The set of models constructed from the sub-sample of respondents with explicit existence value argumentation differ a bit from the set of models on all respondents (Tab. 6). Adjusted Pseudo- $\mathrm{R}^{2}$ values are higher. This time, the interaction with the severity item (model c) gives, judged by the value of the log-likelihood function, the best statistics by a thin margin. Like in the set of models on all respondents, the species aesthetics attribute does not become significant. Access restrictions for conservation concerns do not become significant.

The coefficients of the three moss existence value terms in models (a), (b) and (c) are highly significant at $\mathrm{P}<0.01$. When the raw coefficients of the interaction terms are multiplied with sample means of the interacted variables, coefficients are: model (a): $0.2036(\mathrm{P}<0.01)$, model (b): 0.1817 
$(\mathrm{P}<0.01)$, model (c): $0.2023(\mathrm{P}<0.01)$.

Tab. 6. Set of restricted models on sub-sample with explicit existence value motivation $(\mathrm{n}=96)$.

\begin{tabular}{|c|c|c|c|}
\hline Variable & $\begin{array}{c}\text { (a) } \\
\text { Non-Interacted } \\
\text { Terms } \\
\end{array}$ & $\begin{array}{c}\text { (b) } \\
\text { Interaction } \\
\text { moss*moss value }\end{array}$ & $\begin{array}{c}(c) \\
\text { Interaction } \\
\text { moss*moss severity }\end{array}$ \\
\hline Landscape Change & $0.1160^{*}$ & $0.1160^{*}$ & $0.1161^{*}$ \\
\hline Access Restrictions (private) ${ }^{\$}$ & $0.1808 * * *$ & $0.1807 * * *$ & $0.1813 * * *$ \\
\hline Access Restrictions (conservation) ${ }^{S}$ & $\odot .0165^{(\mathrm{ns})}$ & $\odot .0151^{(\mathrm{ns})}$ & $\odot .0161^{(\mathrm{ns})}$ \\
\hline Possibility to see three species & $-0.0164^{(\mathrm{ns})}$ & $-\odot .0170^{(\mathrm{ns})}$ & $-\odot .0161^{(\mathrm{ns})}$ \\
\hline $\begin{array}{l}\text { Visits of hummingbirds with } \\
\text { ethno-symbolic value }\end{array}$ & $0.6033^{* * *}$ & $0.6032^{* * *}$ & $0.6010 * * *$ \\
\hline Ecosystem Health & $0.0005^{* * *}$ & $0.0005^{* * *}$ & $0.0005^{* * *}$ \\
\hline \multicolumn{4}{|l|}{ Moss existence } \\
\hline Non- interacted term & 0.2036 ** & - & - \\
\hline Interaction with value [mean $]^{\$}$ & - & $0.1817^{* *}$ & \\
\hline Interaction with severity $[\text { mean }]^{\$}$ & - & - & $0.2023^{*} *$ \\
\hline Moss secure & - & - & - \\
\hline Moss non- secure & - & - & - \\
\hline Income Change ${ }^{\S}$ & $0.0081^{* *}$ & $0.0081^{* *}$ & $\odot .0 \odot 82^{* *}$ \\
\hline ASC $*$ Education $^{\$}$ & $-0.7159^{* \star *}$ & $-0.7281^{* * *}$ & $-0.7130 * * *$ \\
\hline Log-likelihood & -716.70 & -717.19 & -716.49 \\
\hline Restricted Log-likelihood & -950.30 & -950.30 & -950.30 \\
\hline $\mathrm{P}\left(\mathrm{Chi}^{2}\right) ; \mathrm{DF}$ & $<0.0001 ; 10$ & $<0.0001 ; 10$ & $<0.0001 ; 10$ \\
\hline Inclusive value (IV) & 0.9341 & $\odot .9309$ & 0.9376 \\
\hline Adj. $\rho^{2}$ (Pseudo-R $\left.{ }^{2}\right)$ & 0.2408 & 0.2404 & 0.2411 \\
\hline
\end{tabular}

***: significant at $\mathrm{p} \leq 0.001 ;{ }^{* *}$ : significant at $\mathrm{p} \leq 0.01$; ${ }^{*}$ : significant at $\mathrm{p} \leq 0.05 ;{ }^{\mathrm{S}}$ raw coefficients multiplied with the sample means (see Tab. 4); ${ }^{8}$ cost coefficient for 1,000 CHP/yr/household; DF: degrees of freedom; ${ }^{\#}$ all IV statistics are highly significantly different from 0 ; Nested Logit models based on 96 respondents with 8 choices each.

\subsection{Marginal Willingness to Accept}

Based on the best performed models from both sets (Tables 5 (a) and 6 (c)), Table 7 compares marginal WTA values (implicit prices). Marginal WTA values for the probability of moss extinction are $\sim 69,000 \mathrm{CHP} /$ month for the total sample and $\sim 49,600 \mathrm{CHP} /$ month for the respondents with existence value motivation. For access restrictions for private concerns marginal WTA is $\sim 22,070 \mathrm{CHP} / \mathrm{month}$ for the entire sample and $\sim 22,200 \mathrm{CHP} /$ month for the existence value subsample. WTA for access restrictions to nature for conservation concerns $(\sim 15,200 \mathrm{CHP} / \mathrm{month})$ results lower than WTA for private concerns for all respondents. Marginal WTA for change on landscape by tourist impact is $\sim 28,500 \mathrm{CHP} /$ month for the sub-sample with existence value motivations and $\sim 30,000 \mathrm{CHP} /$ month for all respondents. Marginal changes in the attribute levels on hummingbirds presence result in the highest WTA values in excess of $\sim 73,000 \mathrm{CHP} / \mathrm{month}$, for 
the entire and existence value samples. Marginal WTA for the loss of one of about 1,600 species on the island with respect to species contribution to the "health, vigour, and resistance of nature" is $66 \mathrm{CHP} /$ month for the respondents with existence value motivations and $\sim 93 \mathrm{CHP} / \mathrm{month}$ for the total sample. The ASC interaction indicates that respondents, on average, have a status quo bias equivalent to $\sim 87,400 \mathrm{CHP} /$ month for the existence value sub-sample, or respectively, $\sim 54,700 \mathrm{CHP} /$ month for all respondents.

Tab. 7. Implicit prices.

\begin{tabular}{|c|c|c|c|}
\hline Attribute & $\begin{array}{c}\text { "Marginal"§ Unit used for } \\
\text { calculation including } \\
\text { coding }\end{array}$ & $\begin{array}{l}\text { All respondents } \\
\text { [CHP/month] }\end{array}$ & $\begin{array}{c}\text { Existence value } \\
\text { sub-sample } \\
\text { [CHP/month] } \\
\end{array}$ \\
\hline $\begin{array}{l}\text { Probability of extinction of an } \\
\text { endemic moss }\end{array}$ & $\begin{array}{l}\text { Low probability of extinc- } \\
\text { tion }(+1) \text { to increased } \\
\text { probability of extinction } \\
(-1)^{\S}\end{array}$ & 69,040 & 49,635 \\
\hline $\begin{array}{l}\text { Change of landscape by impact } \\
\text { of tourist infrastructure }\end{array}$ & $\begin{array}{l}\text { very small change }(-1) \text { to } \\
\text { small change }(+1)^{\S}\end{array}$ & 29,995 & 28,492 \\
\hline $\begin{array}{l}\text { Access restrictions to nature for } \\
\text { private concerns }\end{array}$ & Next restriction level & 22,074 & 22,247 \\
\hline $\begin{array}{l}\text { Access restrictions to nature for } \\
\text { conservation concerns }\end{array}$ & Next restriction level & 15,220 & $1,972^{(\mathrm{ns})}$ \\
\hline $\begin{array}{l}\text { Possibility to see woodpeckers, } \\
\text { guanacos and condors }\end{array}$ & $\begin{array}{l}\text { See species } 25 \% \text { less often } \\
(-2) \text { than now }(+2)^{\S}\end{array}$ & $12,796^{(\mathrm{ns})}$ & $-7,921^{(\mathrm{ns})}$ \\
\hline $\begin{array}{l}\text { The hummingbirds visit the } \\
\text { island }\end{array}$ & $\begin{array}{l}\text { Next level of securing } \\
\text { humming bird presence }\end{array}$ & 86,593 & 73,742 \\
\hline $\begin{array}{l}\text { Number of types of animals } \\
\text { and plants indicating "health, } \\
\text { resistance and vigour of nature" }\end{array}$ & $\begin{array}{l}\text { Loss of } 1 \text { of } 1600 \text { species } \\
\text { on the island }\end{array}$ & 93 & 66 \\
\hline ASC ${ }^{*}$ Education [ [*mean Educ.] & $\begin{array}{l}\text { Deviation from status quo } \\
\text { as offered by choices }\end{array}$ & $-54,745$ & $-87,486$ \\
\hline Number of respondents & & 230 & 96 \\
\hline
\end{tabular}

\footnotetext{
\$Because the non-linear, inverted U-shape coding results in changing marginal WTA values, the 'marginal' step used for the calculation is explicitly given. In both cases, the step represents a change from a status quo level to an adjacent attribute level; ${ }^{(n s)}$ the coefficient is not significant in models (see Tabs. 5 and 6).
} 


\section{Discussion}

In this section we provide an anaylsis of the results of the study. Section 7.1 picks up a general overview of the investigation and section 7.2 presents a discussion on the trade-off behaviour of the existence value motivated sub-sample.

\subsection{Overview}

We assessed the economic existence value of a single species endemic to the subanctarctic forests of Patagonia in Chile. First, we considered the main criticisms for the attempts to estimate economic existence value and second, investigated if a novel strategy which uses the concept of exchange value can contribute to give response to these criticisms. The methodological strategy consisted on applying a choice experiment approach.

For the entire sample, the attribute related to moss existence value was strongly significant and positive. This indicates that a positive value exists for this endemic species protection.

The qualitative information of our study reveals that $86 \%$ of the participants have a positive attitude with regard to the protection of the existence of an endemic species. However, $42 \%$ of the respondents spontaneously gave reasons to care about moss extinction, attributable to an existence value motivation. This is an indication of the complexity of the valuation dimension. Many participants' arguments involved only indirect use values when asked for the reasons or motives to care for the existence of the endemic moss.

Performing a NL model with the existence value motivated sub-sample, the moss attribute also emerges as significant and explanatory of choice. As expressed in section 5.2.1.3 validity would be supported if a statistically significant WTA value can be documented for respondents with clear existence value motivation, and if the PMT qualitative variables included into study explain preference variations conforming with social-psychological theory. Differing from the significant interactions with the other attributes (see Cerda et al. 2006; Chapter III this thesis), the inclusion of the PMT variables does not lead to substantially improve model fit when interacted with the moss attribute. 
Table 6 shows that the existence value motivated group, do not care about additional restrictions to the landscape for conservation concerns as indicated by the no significance of the attribute. In the same way, the possibility to see animals become not significant for this group of respondents. It was expected that existence value motivated respondents would have stronger preferences for additional restrictions for conservation initiatives. However, the existence value is not restricted to any more else in this case study. This indicates an effective isolation of this value category. We also learned that the overall WTA is not higher for those existence value motivated people.

\subsection{Trade off- analysis}

The design of the study isolated existence value because respondents made simultaneous tradeoffs between existence value of an endemic moss and five other biodiversity related use values and indirect use values. The results indicate that the participants were able to trade-off different biodiversity-related goods and services - one of which is the existence of an endemic moss species -, against a monetary attribute. We did not experience protests responses caused by ethical concerns on trading-off the existence of an endemic species against a compensation in money. However, with respect to the entire sample $(n=230), 62$ respondents never chose an option which would compromise the current conservation status of the endemic moss and/or imply a substantial loss of species in the ecosystem health attribute. Although this choice pattern could be interpreted as an expression of lexicographic preferences on part of a minority of respondents, one has to keep in mind, however, that we also included an attribute level leading to an - in relation to the status quo - improved level of moss survival. All respondents traded off the best level of moss protection at least once. Additionally, it is likely that the increases in income offered to the respondents during the CE application, were not high enough to accept the change from the current to the worst level of moss protection.

\subsubsection{Trade off analysis of the existence value motivated sub-sample}

\subsubsection{Trade off of moss existence}

At a more detailed analysis of the existence value motivated sub-sample $(n=96), 87$ respondents choose the option A or B at least once and 9 respondents chose always the Status Quo option. 
Tab. 8 shows details of respondents' behaviour.

Tab. 8. Details of choices of the existence value motivated sub-sample ( $\mathrm{n}=96)$.

\begin{tabular}{clc}
\hline Choice & Trade-off involving moss protection & \multicolumn{1}{c}{$\begin{array}{c}\mathbf{N}^{\circ} \text { of } \\
\text { respondents }\end{array}$} \\
\hline \hline & $\begin{array}{l}\text { (a) Chose worst level of moss protection at } \\
\text { least once. }\end{array}$ & 43 \\
$\begin{array}{c}\text { Option A or B at least once } \\
(\mathrm{n}=87)\end{array}$ & $\begin{array}{l}\text { (b) The worst level of moss protection is never } \\
\text { chosen. Trade-off between the current and best } \\
\text { levels of moss protection only. }\end{array}$ & 44 \\
\hline $\begin{array}{c}\text { Always the Status Quo option } \\
(\mathrm{n}=9)\end{array}$ & $\begin{array}{l}\text { (c) Always chose the Status Quo option } \\
\text { (current level of moss protection). }\end{array}$ & 9 \\
\hline \hline
\end{tabular}

The trade-off analysis for this group of people will be done in two steps, first we sketch fundamental ways how to model and describe the willingness to trade-off moss existence value versus a combination of income changes and changes in the other environmental attributes of the CE. Second, we investigate which of these models could explain the empirically observed choice patterns of the respondents with an explicit existence value argumentation. We identify trade-off models that can map the empirically observed choice behaviour of the entire group of respondents.

\section{Step 1}

The CE scenarios offered to respondents differ in various aspects from the Status Quo: they differ with regard to the level of moss protection $\left(\mathrm{Z}_{\mathrm{m}}\right)$, the offered income change $(\mathrm{Y})$, and a vector of changes in the other attributes $\left(\mathrm{Z}_{\mathrm{i}}\right)$. Focusing on the deterministic utility components and our random utility theory model (see sec. 4 ) the deterministic utility part V equals:

$$
\mathrm{V}=\mathrm{b}_{\mathrm{m}} * \mathrm{Z}_{\mathrm{m}}+\mathrm{b}_{\mathrm{c}} * \mathrm{Y}+\Sigma \mathrm{b}_{\mathrm{i}} * \mathrm{Z}_{\mathrm{i}}
$$

with $b_{m}$ : utility coefficient of the moss attribute; $b_{c}$ : utility coefficient of income change; 
$b_{\mathrm{i}}$ : utility coefficients of all other attributes.

If the terms of the above equation are divided by the coefficient of the income change attribute, we obtain a monetarized form of the equation. In this equation income change directly influences the modified utility measure $\mathrm{V}_{\mathrm{b}}$ as well as the monetary equivalent of the changes in the moss attribute and the other attributes.

$$
\mathrm{V}_{\mathrm{b}}=\mathrm{V} / \mathrm{b}_{\mathrm{c}}=\left(\mathrm{b}_{\mathrm{m}} * \mathrm{Z}_{\mathrm{m}}\right) / \mathrm{b}_{\mathrm{c}}+\mathrm{Y}+\left(1 / \mathrm{b}_{\mathrm{c}}\right) *\left(\Sigma \mathrm{b}_{\mathrm{i}} * \mathrm{Z}_{\mathrm{i}}\right)
$$

The income change and the monetarized value of the other environmental changes except the moss, can be combined into one variable: Total non-moss Scenario Value (TnmSV). Depending on the particular scenario, TnmSV represents a positive value (improvement over the status quo: WTA), or a negative value (disimprovement over the status quo: WTP). The description of TnmSV as either WTP or WTA is relative to potential opposite changes of the moss attribute. So the above equation can be simplified to:

$$
\mathrm{V}_{\mathrm{b}}=\left(\mathrm{b}_{\mathrm{m}}{ }^{*} \mathrm{Z}_{\mathrm{m}}\right)+\mathrm{TnmSV}
$$

In the $\mathrm{CE}$, respondents are faced with cards that represent different deterministic combinations of the terms of the above utility function, let say of utility $V_{1}$ and $V_{0} . V_{0}$ represents the status quo. With regard to the trade-off analysis, two situations are particularly interesting. The first one is when $\mathrm{V}_{1}$ includes a move to a worse level of moss protection $\left(\mathrm{Z}_{\mathrm{m} 0}=>\mathrm{Z}_{\mathrm{m} 1}=\mathrm{Z}_{\mathrm{m} \text {-worse }}\right)$. Here it is interesting to ask if the maximum offered compensation is enough for respondents to chose $V_{1}$ over the Status Quo with utility $\mathrm{V}_{0}$. This maximum compensation we denote as MaxWTA. Alternatively we consider an improvement of the moss attribute $\left(Z_{\mathrm{m} 0}=>Z_{\mathrm{m} 1}=Z_{\mathrm{m} \text {-best }}\right)$. Is the smallest offered vector of disadvantages (MinWTP) small enough for respondents to chose the improvement over the status quo so that $\mathrm{V}_{1}>\mathrm{V}_{0}$ ?

Step 2

Now we are in the position to outline fundamental ways how to model trade-off relationships. The first situation is characterized by lexicographic preferences. Individuals with lexicographic 
preferences categorically disagree with the implementation of developments that would reduce a certain aspect of environmental quality. In our case some respondents may have lexicographic preferences with regard to moss existence. Formally lexicographic preferences for moss existence would be defined as follows:

$$
\mathrm{V}\left(\mathrm{Z}_{\mathrm{m} 1}, \mathrm{Z}_{\mathrm{i} 1}, \mathrm{Y}_{1}\right)=\mathrm{V}\left(\mathrm{Z}_{\mathrm{m} 0}, \mathrm{Z}_{\mathrm{i} 0}, \mathrm{Y}_{0}\right)
$$

only if

$$
\mathrm{Z}_{\mathrm{m} 1}=\mathrm{Z}_{\mathrm{m} 0}
$$

and

$$
\mathrm{V}\left(\mathrm{Z}_{\mathrm{i} 1}, \mathrm{Y}_{1}\right)=\mathrm{V}\left(\mathrm{Z}_{\mathrm{i} 0}, \mathrm{Y}_{0}\right)
$$

This means that no indifference curves between different bundles of moss protection on the one hand side, and combinations of income and the other environmental changes on the other hand side, exist. If such bundles are compared, one bundle is preferred over a second bundle.

$$
\mathrm{V}\left(\mathrm{Z}_{\mathrm{m} 1}, \mathrm{Z}_{\mathrm{i} 1}, \mathrm{Y}_{1}\right)>\mathrm{V}\left(\mathrm{Z}_{\mathrm{m} 0}, \mathrm{Z}_{\mathrm{i} 0}, \mathrm{Y}_{0}\right)
$$

only if either

$$
\mathrm{Z}_{\mathrm{m} 1}>\mathrm{Z}_{\mathrm{m} 0} \text { or } \mathrm{Z}_{\mathrm{m} 1}=\mathrm{Z}_{\mathrm{m} 0}
$$

while

$$
\mathrm{V}\left(\mathrm{Z}_{\mathrm{i} 1}, \mathrm{Y}_{1}\right)>\mathrm{V}\left(\mathrm{Z}_{\mathrm{i} 0}, \mathrm{Y}_{0}\right)
$$


Does any of the three groups of respondents in Table 8 have lexicographic preferences? Group (a) respondents do not because, in contradiction to (7a), at least once they preferred a scenario with a worse level of moss protection to the Status Quo. Respondents from group (b) never accepted a worse level of moss protection to the Status Quo, but at least once traded-off an improvement of the Status Quo against other advantages. Thus, they also violated the same condition (7a) for lexicographic preferences. Respondents always chosing the Status Quo (group c) fall into the same category because improvements in moss protection have been offered to them but they decided to chose the Status Quo, nevertheless.

Even without having lexicographic preferences, some respondents may have categorically limited willingness to substitute deterioration of the protection status of the moss by an improved availability of income or other environmental benefits. In this case indifference curves exist but they are not strictly convex and "well-behaved". Formally, the indirect curves would be defined as follows (c.f. Marggraf \& Streb 1997):

$$
\mathrm{V}=\min \left[\mathrm{V}\left(\mathrm{Z}_{\mathrm{m}}\right), \mathrm{V}\left(\mathrm{Y}, \mathrm{Z}_{\mathrm{i}}\right) / \mathrm{k}\right]
$$

with $\mathrm{k}$ : positive constant

$$
\mathrm{V}_{\mathrm{b}}=\min \left[\mathrm{b}_{\mathrm{m}} * \mathrm{Z}_{\mathrm{m}} ; 1 / \mathrm{k} *\left(\mathrm{Y}+\Sigma \mathrm{b}_{\mathrm{i}} / \mathrm{b}_{\mathrm{c}} * \mathrm{Z}_{\mathrm{i}}\right)\right]
$$

Fig. 4 shows this type of behaviour. The $\mathrm{Z}$ axis represents different levels of moss protection and the vertical axis (TnmSV) represents the income change and the monetarized value of the other environmental changes presented in the $\mathrm{CE}$, except the moss. $\mathrm{U}^{0}, \mathrm{U}^{1}$ and $\mathrm{U}^{2}$ represent indifference curves linking combinations of moss protection levels and TnmSV levels. At present, individuals are at point 1 , enjoying $Z_{c}$ of moss protection and $\operatorname{TnmSV}_{0}$. Suppose a deterioration of moss protection from $Z_{c}$ to $Z_{\mathrm{w}}$. As can be seen, no increase in TnmSV can reach $\mathrm{U}^{0}$ again. Consider now an improvement of moss protection from $Z_{c}$ to $Z_{b}$. Here we observe two situations indicated by points $3(\mathrm{a}) /(\mathrm{b})$. At point 3(a), individuals have moved to a higher level of utility $\mathrm{U}^{2}$. 
The compensating variation required to reach $\mathrm{U}^{0}$ again is represented by $\mathrm{CV}_{\mathrm{b}}$. At point $3(\mathrm{~b})$ individuals enjoy $Z_{b}$ but the improvement from $Z_{c}$ to $Z_{b}$ is not enough to move to a higher level of utility.

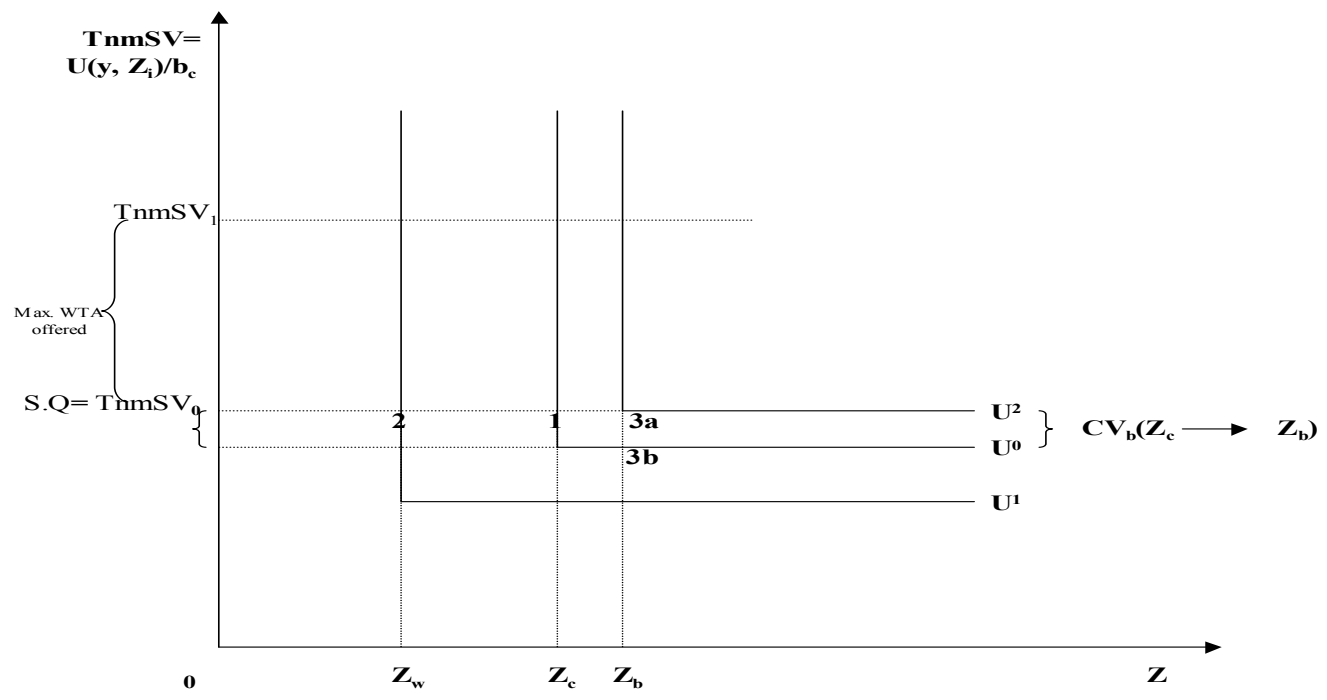

Fig. 4. L-type preferences.

Source: Adapted from Marggraf \& Streb (1997: 226).

Are groups in Tab. 8 compatible with the depicted preference structure in Fig. 4 ?

- Group (a) is clearly not, as people trade-off the worst level of moss protection at least once. The MaxWTA offered was higher than the compensating variation required to move from $Z_{\mathrm{c}}$ to $Z_{\mathrm{w}}$.

- Groups (b) and (c) may be represented by the depicted preference structure. No increase in TnmSV would compensate the change from $Z_{c}$ to $Z_{w}$. With respect to the change from $\mathrm{Z}_{\mathrm{c}}$ to $\mathrm{Z}_{\mathrm{b}}$, the group (b) would accept the change because the compensating variation is higher than the MaxWTP offered during the CE application (see point 3a in Fig. 4). Some respondents of group (b) may also we willing to accept this change without representing a change from $\mathrm{U}^{0}$ to $\mathrm{U}^{2}$ to them, however (point $3 \mathrm{~b}$ in Fig. 4). Group (c) does not chose the best level of moss protection. Perhaps, $\mathrm{Z}_{\mathrm{b}}$ does not represent a real improvement with respect to $Z_{c}$, or the MaxWTP required by the CE is higher than the compensating variation 
to move from $Z_{c}$ to $Z_{b}$.

Now, Figures 5 and 6 depict the case of well-behaved, strictly convex utility curves. Preferences for moss existence of group (a) are well-behaved and it may also be the case for groups (b) and (c). Figure 5, explains the trade-off of group (a) in Tab. 8.

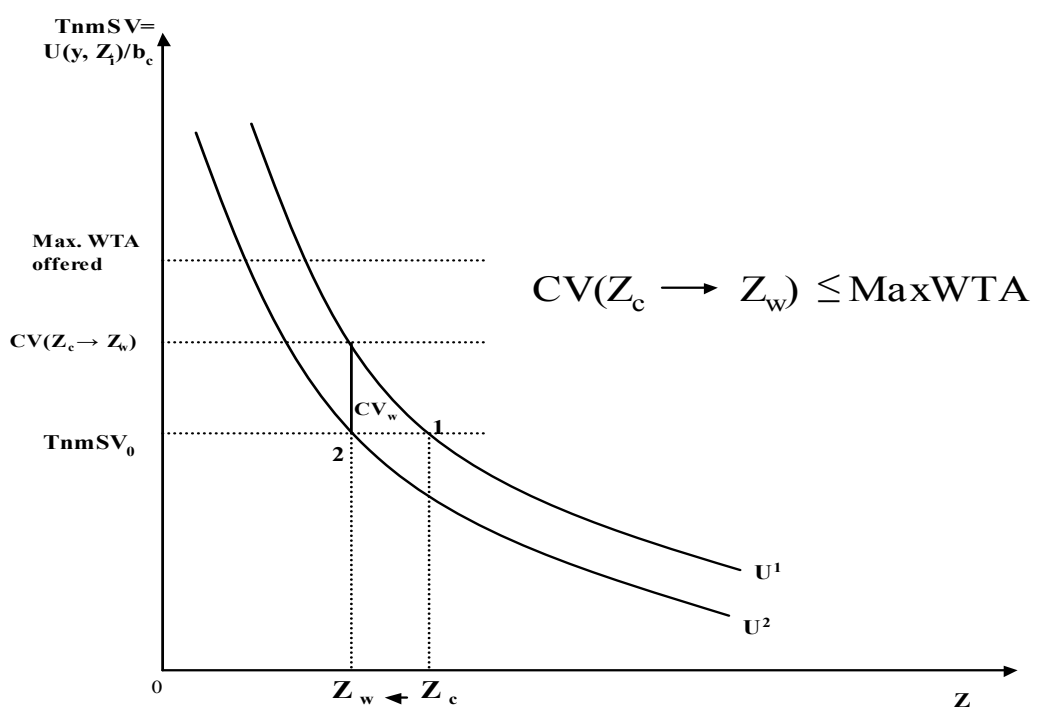

Fig. 5. Well-behaved convex utility curves (group (a) in Tab. 8; $\mathrm{n}=43$ ).

Fig. 5 shows that 43 respondents enjoy $Z_{c}$ of moss protection and $\operatorname{TnmSV}_{0}$ at present. So, they are at point 1 with the corresponding level of welfare $\mathrm{U}^{1}$. Assuming a change from $\mathrm{Z}_{\mathrm{c}}$ (low probability of extinction) to $\mathrm{Z}_{\mathrm{w}}$ (increased probability of extinction) they would move to a worse level of welfare indicated by point 2 which is in the utility curve $U^{2}$. This group of people chose $Z_{w}$ at least once because the compensating variation $\left(\mathrm{CV}_{\mathrm{w}}\right)$ to move from $Z_{\mathrm{c}}$ to $Z_{\mathrm{w}}$ is lower than the MaxWTA offered by the study. 
Figure 6, explains the trade-off of groups (b) and (c) in Tab. 8.

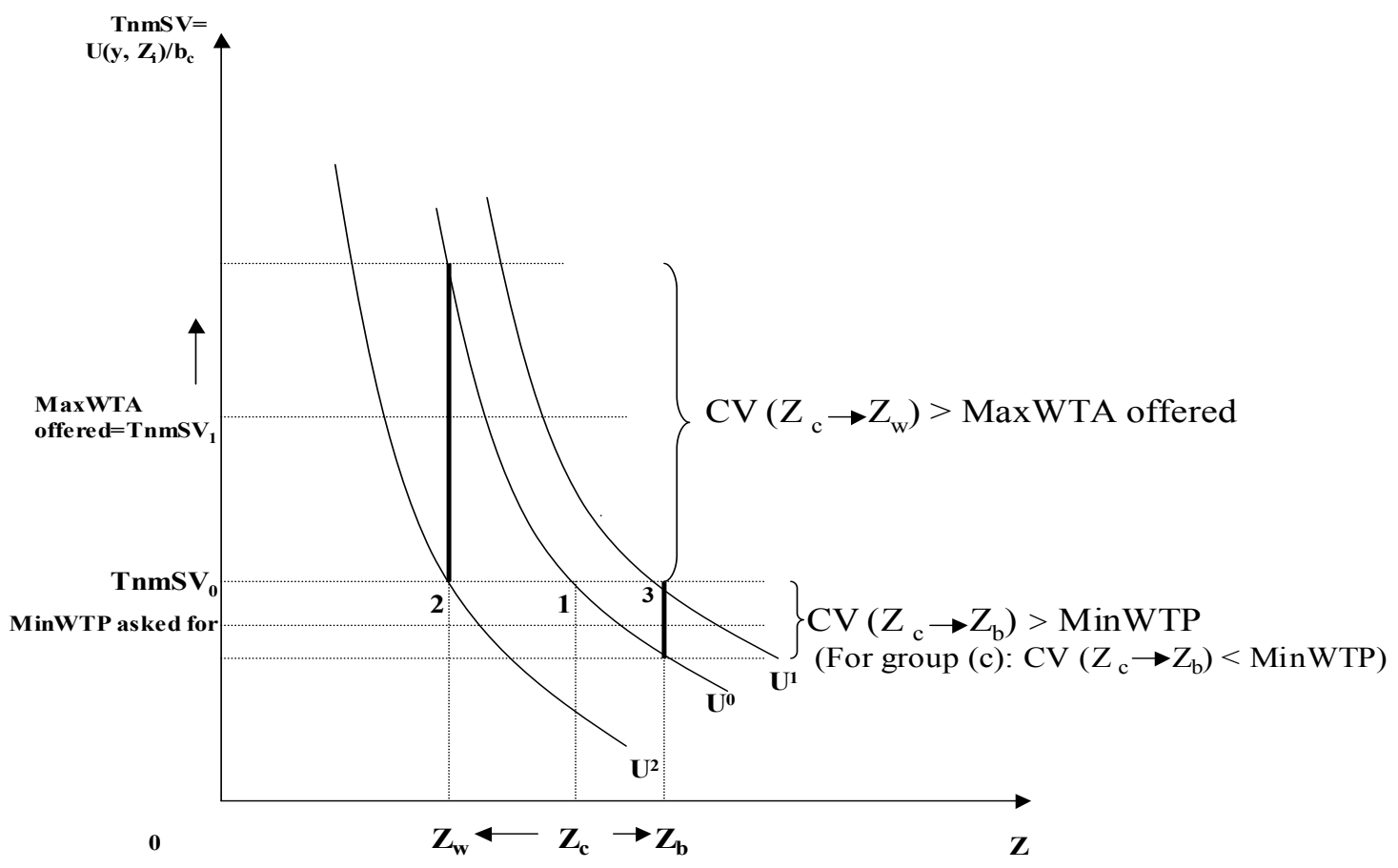

Fig. 6. Well-behaved convex utility curves (groups (b) and (c) in Tab. 8; n=53).

At present, the respondents of groups (b) and (c) are at point 1, enjoying $Z_{c}$ of moss protection and $\mathrm{TnmSV}_{0}$, and are in the utility curve $\mathrm{U}^{0}$. First, we assume a planning situation in which the level of moss protection decreases from $\mathrm{Z}_{\mathrm{c}}$ (low probability of extinction) to $\mathrm{Z}_{\mathrm{w}}$ (increased probability of extinction). After the contemplated environmental change, individuals would move to the less comfortable level of welfare $U^{2}$. Notice that the compensating variation $(\mathrm{CV})$ required for such a change is higher than the MaxWTA offered $\left(\mathrm{TnmSV}_{1}\right)$. Thus, this group of people does not accept the change from $Z_{c}$ to $Z_{w}$.

We assume now an improvement of moss protection from $\mathrm{Z}_{\mathrm{c}}$ (low probability of exinction) to $\mathrm{Z}_{\mathrm{b}}$ (very low probability of extinction). People would move to $\mathrm{U}^{1}$ which represents a more confortable level of welfare if compared to $\mathrm{U}^{0}$. For the case of group (b), it can be observed that the compensating variation associated to move from $Z_{c}$ to $Z_{b}$ is higher than the MinWTP asked for. Thus, $Z_{c}$ and $Z_{b}$ are traded-off. For the case of people who always chose the status quo (group $\mathrm{c}$ in Tab. 8), it is likely that the compensating variation to move from $Z_{c}$ to $Z_{b}$ is lower than the 
MinWTP asked for.

\section{Conclusion of the trade-off analysis}

From the trade-off analysis for the existence value motivated sub-sample we conclude the following:

- Lexicographic preferences are ruled out for the entire sub-sample. Our strategy of using more than just two dichotomus attribute levels of moss protection, avoided lexicographic behaviour as all respondents traded-off the best level of moss protection at least once.

- $\quad$ L-type preferences (Fig. 4), may explain behaviour of groups (b) and (c) in Tab. 8. With the information obtained by the study we can not have absolute certainty of the occurrence of this behaviour, however.

- Well-behaved preferences are possible for all groups of the sub-sample (see Figs. 5 and 6). The results provide absolute certainty that group (a) in Tab. 8 has well-behaved preferences for moss existence. Although this may also be the case for groups (b) and (c), with the information obtained by the study, it is not possible to corroborate in this regard.

\section{Conclusion}

The concurrent utilisation of six biodiversity-related attributes, four of which on different value aspects of species diversity, facilitated the isolation of the existence value. Mean value estimates for existence value differed between the entire sample, and 96 respondents who explicitly mentioned existence value argumentations with regard to the risk of moss extinction. This mean value is not higher for those existence value motivated respondents.

We had expected that the qualitative attitudinal information on moss existence would explain part of the variation in preferences for existence value. Probably, the PMT value variable did not reflect well the ethical concerns underlying existence value preferences. For the case of the PMT 
variable "severity", maybe, the "ecological" severity of the loss of the moss species would indicate an (indirect) use value of the moss for the existence value motivated sub-sample.

Still, our results indicate that a choice experiment approach represents a suitable way in attempting to estimate existence values of single species. This strategy generated a meaningful marginal value for the existence of an endemic species for Navarino island residents, while avoiding problems related to ill value isolation, protest responses, and lexicographic preferences. 


\section{Literature}

Adamovicz, W., Louviere, J \& Williams, M. (1994). Combining Revealed and Stated Preference Methods for Valuing Environmental Amenities. Journal of Environmental Economics and Management 26, 271-292.

Adamovicz, W., Boxall, P., Williams, M. \& Louviere, J. (1998). Sated Preference Approaches for Measuring Passive Use Values: Choice Experiment and Contingent Valuation. American Journal of Agricultural Economics 80, 64-75.

Arango, X. \& Rozzi, R. (2005). El Carpintero Gigante (Campephilus Magellanicus): Una especie carismática al fin del mundo. Poster Presentation at the International Conference "Integrating biodiversity science for human well-being”, Oaxaca, Mexico, November 9-12. 2005.

Arrow, K., Solow, R., Portney, P. R., Learner, E. E., Radner, R. \& Schuman, H. (1993). Report of the NOAA Panel on Contingent Valuation. Washington, D. C.: Resources for the Future.

Barkmann, J. \& Marggraf, R. (2004). The long-term protection of biological diversity - lessons from market ethics. Poiesis Prax 3, 3-21.

Barkmann, J., Cerda, C. \& Marggraf, R. (2005). Interdisziplinäre Analyse von Naturbildern: Notwendige Voraussetzung für die ökonomische Bewertung der natürlichen Umwelt. Umweltpsychologie 9, 10-29.

Barkmann, J., Glenk, K., Handi, H., Sundawati, L., Witte, J. \& Marggraf, R. (2006). Assessing economic preferences for biological diversity and ecosystem services at the Central Sulawesi rainforest margin - a choice experiment approach. Submitted to: Tscharntke, T., Leuschner, C., Guhardja, E. \& Zeller, M. (eds.): The Stability of Tropical Rainforest Margins: Linking Ecological, Economic and Social Constraints of Land Use and Conservation. Environmental Science Series. Heidelberg, New York: Springer. 
Bateman, I \& Willis, K. G. (eds.). (1999). Valuing Environmental Preferences. Theory and Practice of the Contingent Valuation Method in the US, EU, and Developing Countries. Oxford (UK): Oxford University Press.

Bateman, I., Carson, R., Day, B., Hanemann, M., Hanley, N., Hett, T., Jones-Lee, M., Loomes, G., Mourato, S., Özdemiroglu, E., Pearce OBE, D.W., Sugden, R., \& Swanson, R. (eds.). (2002). Economic Valuation with Stated Preference Techniques: A Manual. Cheltenham (UK): Edward Elgar.

Bennett, J. \& Blamey, R. (eds.). (2001). The Choice Modelling Approach to Environmental Valuation. Cheltenham (UK): Edwar Elgar.

Bennett, J. \& Adamovicz, V. (2001). Some fundamentals of Environmental Choice Modelling. In: Bennett, J. \& Blamey, R. (eds.): The Choice Modelling Approach to Environmental Valuation, (pp. 37-69). Cheltenham (UK): Edwar Elgar.

Berghöfer, U. (2005). Imágenes de Naturaleza en isla Navarino. In: Arango, X., Berghöfer, A., Berghöfer, U., Cerda, C., Draguicevic, J., Fistric, S., Jax, K., Ojeda, M., Rozzi, R., Schüttler, E. (eds.): Vivir en la isla Navarino: Un mundo diverso en el fin del mundo (pp. 24-32). Centre for Environmental Research (UFZ). Leipzig-Halle. Germany.

Boxall, P.C., Adamovicz, W. L., Swait, P., Williams, M. \& Louviere, J. (1996). A comparison of Stated Preference Methods for Environmental Valuation. Ecological Economics 18(3), 243253.

Boyle, K. \& Bishop, R. (1987). Valuing Wildlife in Benefit-Cost Analyses: A case study involving endangered species. Water Resource Research 23(5), 943-950.

Brookshire, D., Eubanks, L., \& Randall, A. (1983). Estimating option prices and existence values for resources. Land Economics 59, 1-15. 
Callicott, J. B. (ed.). (1989). In Defense of the Land Ethic: Essays in Environmental Philosophy. Albany: Sunny Press.

Carson, R.T., Mitchell, R. C., Hanemann, M. W., Kopp, R. J., Presser, S. \& Ruud, P. A. (1994). Contingent valuation and lost passive use: damages from the Exxon Valdez. Discussion paper QE94-18. Washington, D. C.: Resources for the Future.

Carson R., Flores, N. E. \& Meade, N. F. (2001). Contingent Valuation: Controversies and Evidence. Environmental and Resource Economics 19, 173-210.

Carson T., Mitchell, R., Hanemann, M., Kopp, R., Presser, S. \& Ruud, P. (2003). Contingent Valuation and Lost Passive Use: Damages from the Exxon Valdez Oil Spill. Environmental and Resource Economics 25, 257-286.

Cerda, C. (2003). Beneficios de la recreación al interior de la Reserva Nacional Lago Penuelas. Tesis para optar al grado de Magíster en Gestión y Planificación Ambiental. Universidad de Chile. Programa Interfacultades.

Cerda, C., Barkmann, J. \& Marggraf, R. (2005). Assessment of Biological Diversity in the context of the CBD Ecosystem Approach: The Participatory Potential of Economic Valuation Techniques. Poster presentation at the international conference: "Biodiversity: Science and Governance". Paris, January 24-28, 2005.

Cerda, C., Barkmann, J. \& Marggraf, R. (2006). Economic non-market valuation of biological diversity of Navarino island, Patagonia, Chile - a choice experiment approach. Chapter III this thesis.

Colombo, S., Calatrava-Requena, J. \& Hanley, N. (2005). Designing policy for reducing the offfarm effects of soil erosion using Choice Experiment. Journal of Agricultural Economics 56(1), 81-95. 
Costanza, R., Norton, B. G. \& Haskell, B. D. (eds.). (1992). Ecosystem Health - New Goals for Environmental Management. Washington, D.C.: Island Press.

Dehnhardt, A. \& Meyerhoff, J. (2002). Nachhaltige Entwicklung der Stromlandschaft Elbe. Nutzen und Kosten der Wiedergewinnung und Renaturierung von Überschwemmungsauen. Kiel: Vauk.

De La Maza, C.L. (1997). Beneficios Monetarios en Áreas Silvestres Protegidas. Aplicación de los Métodos de Valoración Contingente y Costo de Viaje. Proyecto Corporación Nacional Forestal (CONAF)/Programa de las Naciones Unidas para el Desarrollo (PNUD). Santiago. Chile.

Edwars, S. F. (1986). Ethical Preferences and the Assessment of Existence Values: Does the Neoclassical Model Fit? Journal of Agriculture and Resource Economics 15(2), 145-150.

Edwards, S.F. (1992). Rethinking existence Values. Land Economics 68(1), 120-122.

Faber, M., Manstetten, R. \& Proops, J. (eds.) (1996). Ecological Economics: Concepts and Methods. Cheltenham (UK): Eward Elgar.

Freeman, A. M. III. (ed.). (2003). The Measurement of Environmental and Resource Values. Theory and Methods. Washington, D. C.: Resources for the Future.

Hampicke, U. (Hrsg.). (1992). Ökologische Ökonomie. Individuum und Natur in der Neoklassik Natur in der Ökonomischen Theorie: Teil 4. Opladen: Westdeutscher Verlag GmgH.

Hanemann, W.M. (1994). Valuing the Environment through Contingent Valuation. Journal of Economic Perspectives 8(4), 19-43.

Hanemann, W.M. (1996). Theory versus data in contingent valuation debate. In: Bjornstad D.J \& 
Kahn J.R (eds.): The Contingent Valuation of Environmental Resources. Methodological Issues and Research Needs (pp. 38-60). Cheltenham (UK): Edward Elgar.

Hanley, N. \& Spash, C. (1993). Cost-Benefit Analysis and the Environment. - Vermont: Edward Elgar.

Hanley, N., Wright, R. \& Adamowicz, W. (1998). Contingent Valuation versus Choice Experiments : Estimating the Benefits of Environmentally Sensitive Areas in Scotland. Journal of Agricultural Economics 49(1), 1-15.

Hanley, N., Mourato, S. \& Wright, R. E. (2001). Choice Modelling Approaches: A superior Alternative for Environmental Valuation?. Journal of Economic Surveys 15(3), 435-462.

Hensher, D., Rose, J., Greene, W. (eds.) (2005). Applied Choice Methods - A Primer. Cambridge (UK): Cambridge University Press.

Hicks J.R. and G.D. Allen. (1934). A Reconsideration of the Theory of Value. In: Economica London School of Economics and Political Science. (pp. 52-219).

INE (2002). Censo Nacional de Población. Instituto Nacional de Estadísticas. Chile. Available at: www.ine.cl

Jax, K. (2003). BIOKONCHIL - Evaluation of Biological Diversity under the perspective of the Ecosystem Approach of the Convention on Biological Diversity, on the basis of the example of the island Navarino. In Sustainable use and conservation of biological diversity (pp: 374375). Bonn: PT-DLR Umweltforschung.

Kahneman, D. \& Knetsch, J. L. (1992). Valuing Public Goods: The Purchase of Moral Satisfaction. Journal of Environmental Economics and Management 22, 57-70. 
Kopp, R. (1992). Why Existence Value should be included in Cost-Benefit Analysis. Journal of Policy Analysis and Management 11(1), 123-130.

Kotchen, M. \& Reiling, S. (2000). Environmental attitudes, motivations, and contingent valuation of non-use values: a case study involving endangered species. Ecological Economics 32, 93107.

Kramer R., Holmes, T. \& Haefelle, M. (2002). Contingent Valuation of Forest Ecosystem Protection. In: Sills, E. O. \& Lee, K. (eds.): Forests in a market Economy. - Dordrecht. The Netherlands: Kluwer Academic Publishers

Krutilla, J. (1967). Conservation Reconsidered. American Economic Review. 57, 777-786.

Kutsch, W. L., Steinborn, W., Herbst, M., Baumann, R., Barkmann, J. \& Kappen, L. (2001). Environmental Indication: A Field-test of an Ecosystem Approach to Quantify Biological Self-organization. Ecosystems 1, 49-66.

Lazo, J, McClelland, G. \& Schulze, W. D. (1997). Economic Theory and Psychology of Non-Use Values. Land Economics 73(3), 358-371.

Loomis, J. (1988). Broadening the Concept and Measurement of Existence Value. Journal of Agricultural and Resource Economics 17(1), 23-29.

Louviere, J. \& Hensher, D. A. (1982). On the Design and Analysis of Simulated Choice or Allocation Experiments in Travel Choice Modeling. Transportation Research Record 890, 11-17.

Louviere, J. \& Woodworth, G. G. (1983). Design and Analysis of Simulated Consumer Choice or Allocation Experiments: An Approach Based on Aggregated Data. Journal of Marketing Research 20: 350-367. 
Louviere, J., D.A. Hensher, and J.D. Swait. (eds.). (2000). Stated Choice Methods - Analysis and Application. Cambridge (UK): Cambridge University Press

Madariaga, B. \& McConnell, K. (1987). Exploring Existence Value. Water Resources Research 23(5): 936-942.

Marggraf, R. \& Streb, S. (1997). Ökonomische Bewertung der natürlichen Umwelt. Theorie, politische Bedeutung, ethische Diskussion. Heidelberg: Spektrum Akademischer Verlag.

McCann, K. S. (2000). The Diversity Stability Debate. Nature, 405, 228-232.

McFadden, D. (1973). Conditional logit analysis of qualitative choice behavior. In. P. Zarembka (ed.): Frontiers in Econometric (pp. 105-142). New York: Academic Press.

Menzel, S. (2003). Der Beitrag der Protection Motivation Theory für die Interpretation von Zahlungs bereitschaftsäußerungen zur Erhaltung biologischer Vielfalt. Umweltpsychologie 7, 92-112.

Millennium Ecosystem Assessment. (2003). Ecosystems and Human Well-being. A Framework for Assessment. Washington, District of Columbia: Island Press.

Mitchell, R. \& Carson, R. (eds.). (1989). Using Surveys to Value Public Goods: The Contingent Valuation Method. Washington, DC: Resources for the Future.

Nunes, P. and E. Schokkaert. 2001. Warm Glow and Embedding in Contingent Valuation. Available at http://www.feem.it/web/activ/_activ.htlm (accessed November 2005).

O'Riordan, T. \& Stoll-Kleeman, S. (eds.). (2002). Biodiversity, Sustainability and Human Communities: Protecting beyond the Protected. Cambridge: Cambridge University Press. 
Othman, J., Bennett, J. \& Blamey, R. (2004). Environmental Values and Resource Management Options: A Choice Modelling experience in Malaysia. Environmental and Development Economics 9, 803-824.

Pearce, D. (ed.). (1993). Economic Values and the Natural World. London: Earthscan.

Pearce, D.W \& Moran, D. (1994). The economic value of Biodiversity. IUCN - The World Conservation Union. London: Earthscan.

Pearce, D. \& Barbier, E. (eds.). (2000). Blueprint for a Sustainable Economy. London: Earthscan.

Pearce, D. \& Özdemiroglu, E. (2002). Economic Valuation with Stated Preference Techniques. Summary Guide. Department for Transport, Local Government and the Regions: London.

Perrings, Ch., Mäler, K-G., Folke, C., Holling, C. S., \& Jansson, B-O. (eds.). (1995). Biodiversity loss. Economic and ecological issues. Cambridge: Cambridge University Press.

Pimm, S. \& Lawton, J. (1998). Planning for biodiversity. Science 279(5359), 2068-2069.

Randall, A. (1999). Total and Non-use Values. In: A. Randall (ed.): Making the Environment Count (pp. 132-152). Cheltenham (UK): Edward Elgar.

Rogers, R. \& Prentice-Dunn, S. (1997). Protection Motivation Theory. In: Gochman, D. S. (ed.): Handbook of Health Behaviour (pp. 113-132). New York: Plenum Press.

Rozzi, R., Primack, R. \& Massardo, F (2001). Valoración de la Biodiversidad. In: R. Primack, Rozzi, R., Feinsinger, P., Dirzo, R., \& Massardo, F. (eds.): Fundamentos de Conservación Biológica. Perspectivas Lationoamericanas (pp. 255-290). México: Fondo de Cultura Económica. 
Rozzi, R., Massardo, F. \& Anderson, C. (eds.). (2004). The Cape Horn Biosphere Reserve: A Proposal for Conservation and Tourism to Achieve Sustainable Development at the Southern End of the Americas. Punta Arenas, Chile: Ediciones de la Universidad de Magallanes.

Sagoff, M. (ed.). (1988). The Economy of the Earth: Philosophy, Law, and the Environment. New York: Cambridge Community Press.

Sagoff, M. (1996). On the Value of Endangered and Other Species. Environmental Management 20 (6), 897-911.

Sherriffs, M., Anderson, C., Rozzi, R., \& Zúniga, A. (2004). Explorando la Micro-Biodiversidad del Cabo de Hornos. Guías y Actividades. Fundación Omora. Puerto Williams. Chile. Available at: http://www.omora.org

Spash, C.L \& Hanley, N. (1995). Preferences, information and biodiversity preservation. Ecological Economics 12, 191-208.

Spash, C.L. (2000). Ecosystems, contingent valuation and ethics: the case of wetland recreation. Ecological Economics 34, 195-215.

Stevens, T., Echeverría, J., Glass, R., Hager, T., \& More, T. (1991). Measuring the Existence Value of Wildlife: What do CVM estimates really show? Lands Economics 67(4), 390-400.

Stoll, J. \& Johnson, L.A. (1984). Concepts of Value, Non-market valuation and the case of the whooping crane. Transactions of the forty .ninth North American Wildlife and Natural Resources Conference, Wildlife Management Institute, Washington DC.

Walsh R., Loomis, J. \& Gillman, R. (1984). Valuing Option, Existence and Bequest Demand for Wilderness. Land Economics 60, 14-29. 
Yachi, S. \& Loreau, M. (1999). Biodiversity and ecosystem productivity in a fluctuating environment: the insurance hypothesis. - Proceedings of the National Academy of Sciences of the U.S.A. 96, 1463-1468. 


\title{
CHAPTER V
}

\section{WTP/WTA design strategies for choice experiments in early planning stages: experiences from Chile and Kenya}

\author{
Claudia Cerda, Jason Diafas, Jan Barkmann \& Rainer Marggraf
}

\section{Introduction}

One of the most intensively debated methodological issues in environmental economics is the apparent inconsistence of stated preference data depending on whether a willingness-to-pay (WTP) or a willingness to accept compensation (WTA) format is used in the value elicitation instrument. There is relative consensus that economic theory suggests the existence of small deviations of WTP from WTA values. The empirically observed differences are substantially bigger than implied by micro-economic standard theory, however (see e.g., Brown \& Gregory 1999, Horowitz \& McConnell 2002). Sugden (2005) refers to this phenomenon as the WTP/WTA "anomaly". As a consequence of the magnitude of the empirical differences, much of the recent discussion focuses on the question if stated preference methods are fundamentally flawed (Hausman 1993, Portney 1994, Diamond 1996), or if the preference models regularly assumed to underlie stated responses have to be adjusted (e.g., Sugden 1999; prospect theory: Kahneman \& Tversky 1979).

As a minimum condition for the application of stated preference methods, the value elicitation format should be carefully tailored to the research and/or policy issue at hand (see Bateman \& Willis 1999, Bateman et al. 2002). Several reasons, such as usefulness in environmental damage litigation, accounting for income effects, or primary concern for an environmental improvement 
argue for the WTP format (see Ahlheim \& Buchholz 2000), which is often suggested as the standard format (Arrow et al. 1993: 52). Specific distribution of property rights, economic assessment of unavoidable environmental degradations, or concern for the distributional implications of the policy options argue for a WTA format (Ahlheim \& Buchholz 2000, Graves 2003). In light of such considerations, there is some evidence that the scientific discussion moves from a focus on the fundamental suitability of stated preference techniques in face of the WTA-WTP differences to a definition of best practice standards (Sudgen 2005, Braga \& Starmer 2005).

The development and increasingly frequent application of choice modelling (Louviere et al. 2000, Hensher et al. 2005) as a stated preference technique adds an additional facet to the WTPWTA problem. Within one choice set, respondents may be faced with one scenario that asks for increasing income levels (WTA format) and with one scenario that implies a decreasing income (WTP format). For example, one scenario may involve high probability of extinction of one endemic species, calling for a WTA format. In other scenario this species can be protected calling for a WTP format. In particular, when a choice experiment is designed to inform early phases of project planning or policy definition, different value elicitation formats within one choice set can frequently be indicated. This is a consequence of the openness of the planning situation: While most respondents may judge certain realistic scenarios as an environmental deterioration, other also realistic scenarios are likely to be judged as improvements. Thus, an efficient instrument design would allow for using both, WTA and WTP formats, within the same survey instrument. To our knowledge, this implication of the versatility of choice modelling has not been systematically discussed so far.

In the following section 2, we review some of the micro-economic fundamentals on value elicitation formats in stated preference methods (2.1), and provide a brief outline of the WTP-WTA controversy (2.2). Next, the specific needs and requirements regarding the application of stated preference methods in different projects and policy planning stages are analysed (section 3). Section 4 introduces the planning background of one empirical case study, in which choice experiment is used to generate policy advise for early planning stages and in which mixed WTP-WTA design strategies are used. The case study is conducted within the BMBF-funded German biodiversity research program BIOLOG, in Chile (BioTeam; section 4.1). Relevant methodological 
aspects of instrument design are presented in sections 5 for this study. In section 6 we also provide methodological aspects of instrument design of a case study carried out in Kenya (BIOLOGBiota East) in which a mixed WTP-WTA format is also used. As the field work of the Kenyan study has just been finished in April 2006, results will only be presented for the Chilean study. We conclude with a summarising discussion of the need for and applicability of mixed WTP/WTA designs (section 7).

\section{WTP/WTA basics}

Among a number of other issues, the WTP/WTA "anomaly" (Sugden 2005) is among the most critically discussed issues regarding stated preference methods. Within this paper that focuses on WTP/WTA design strategies in early planning phases, we cannot advance the understanding of these fundamental issues beyond the current state of the discussion. Still, a brief introduction into the micro - and welfare economic fundamentals behind the differences between WTP and WTA formats (section 2.1), and an outline of the main lines of the critical discussion (2.2) appear necessary in order to provide a conceptual framework for our contribution.

\subsection{Micro - and welfare-economic basics}

To determine the value that an environmental change has for an individual, Compensating Variation (CV) and Equivalent Variation (EV) measures can be used (see Bateman et al. 2002: 24, Marggraf \& Streb 1997: 87, Freeman 2003: 51). Compensating variation measures assume that an agent is entitled to her current level of utility, or, alternatively, her status quo endowment of property rights. Equivalent variation measures assume that the agent is entitled to some alternative (i.e., different from the actual) level of utility, or, to a set of property rights different from those currently held (Mitchell \& Carson 1989: 25).

Using explanations derived from Bateman et al. (2002: 24) and Marggraf \& Streb (1997: 88-89), Figures 1(a)/(b) illustrate these measures of welfare representing preferences changes for a given individual, for an increase and decrease of a public good. In both figures the vertical axis represents the income of an individual (E). The horizontal axis represents the quantity of some public environmental good $(Z) . U^{1}$ and $U^{2}$ are indifference curves linking combinations of the two goods 
and corresponding to two different levels of welfare. For an exposition in price versus provision with environmental goods, see Freeman (2003: 49).

A summary of the four different situations described in the following paragraphs is provided in Table 1.

For Figure 1(a), we first assume a planning situation in which the quantity of a public good is considered to increase from $Z^{1}$ to $Z^{2}$. At present, the individual has $E^{1}$ income, and finds itself on indifference curve $\mathrm{U}^{1}$ at point 1 . After the contemplated environmental improvement, the individual would enjoy $\mathrm{Z}^{2}$ of the public good and, accordingly, would have moved to the more comfortable welfare level $\mathrm{U}^{2}$. What would be the maximum amount of money the individual should be willing to pay in order to enjoy the improvement from $Z^{1}$ to $Z^{2}$ ? As points 1 and 3 are on the same indifference curve $\mathrm{U}_{1}$, the maximum Willingness to Pay (WTP) for the increase of the public environmental good is the income difference between points 2 and 3: This move would secure the environmental improvement without resulting in a loss of individual welfare. The corresponding loss of income $\mathrm{E}_{1}-\mathrm{E}_{3}$ is the Compensating Variation (CV) for the increase in the public good.

(a)

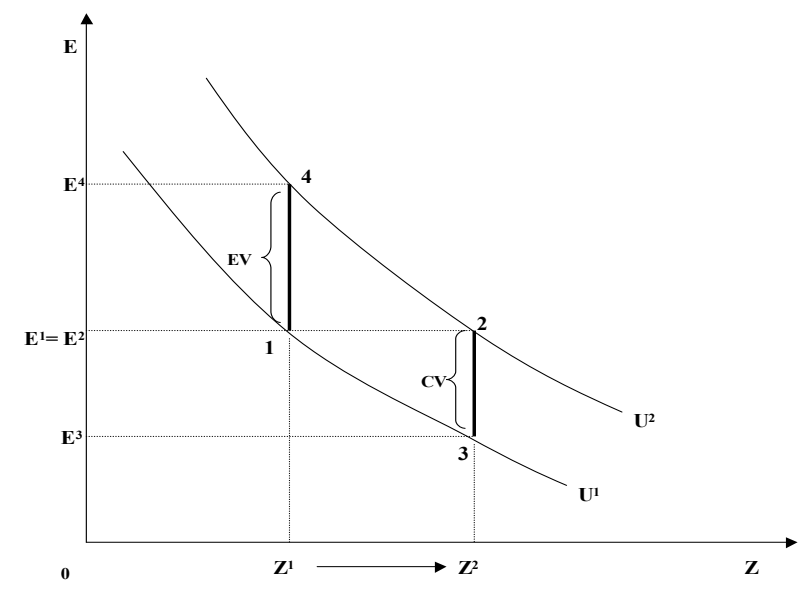

(b)

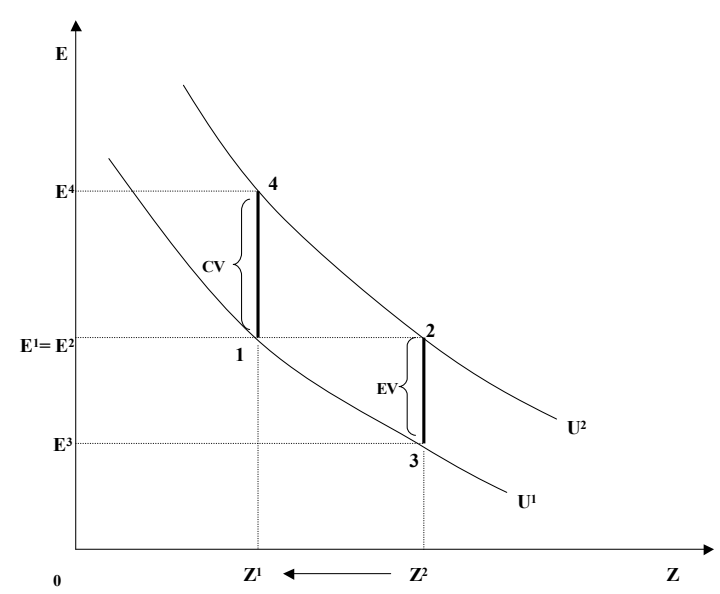

Fig. 1(a)/(b). Increase/decrease in a public environmental good, compensating variation (CV) and equivalent variation (EV) measures; E: income; Z: level of provision of a public environmental good (Source: Marggraf \& Streb 1999) 
Figure 1(a) allows for a second interpretation. Suppose, the individual finds herself at point 1 again, but has already been promised to enjoy an improvement in the provision of the public environmental good from $Z^{1}$ to $Z^{2}$, for example, as a result of an additional nature reserve. Again, this would move the individual to point 2 on $U^{2}$. Because of strong commercial development interest in the promised nature reserve site, an investor could try to 'bribe' individuals to agree to the commercial development. What is the minimum compensation requirement in income terms to agree to the investor proposal? In order not to suffer any welfare loss with respect to the welfare level $U^{2}$ to which our individual feels entitled, she would not be willing to accept any compensation offer (WTA) smaller than $\mathrm{E}^{4}-\mathrm{E}^{2}$ because this compensation keeps her on $\mathrm{U}^{2}$. $\mathrm{E}^{4}-\mathrm{E}^{2}$ is the Equivalent Variation (EV) for an increase in the public good. Given the usual concave form of the indifference curves, $\mathrm{EV}$ is expected to be bigger than $\mathrm{CV}$.

For a decrease in the public good (Fig. 1(b)), a parallel argument can be made. The initial position now is 2 . At point 4 , the individual enjoys only $Z^{1}$ of the public good but her income is greater by $\mathrm{E}_{4}-\mathrm{E}_{2}$. This Willingness to Accept compensation for the reduction in the public good is a CV measure. Alternatively starting from point 2, the individual would be willing to pay a maximum of $E^{2}-E^{3}$ in order to avoid the environmental degradation. This WTP value is the EV for a decrease in the public good. As in the case discussed in Fig. 1(a), WTA is bigger than WTP.

Whether WTP or WTA is the appropriated measure to value environmental changes depends, on one hand side, on the distribution of property rights with regard to the status quo of the environmental good (Mitchel \& Carson 1989: 55). Additionally the appropriate measurement depends on the specific political and socio-economic circumstances since the definition of the choices are often political decisions, too. The discussion above suggests that if an environmental improvement is about to be implemented, WTP should be used. Contrarily, if the project will damage environmental quality, WTA should be chosen. 
Tab. 1. Measures of Economic Valuation.

\begin{tabular}{lll}
\hline \hline Environmental change & \multicolumn{1}{c}{ WTP-WTA } & Welfare measure \\
\hline \hline $\begin{array}{l}\text { Improvement in the provision of } \\
\text { the good }\end{array}$ & WTP for the improvement & Compensating Variation (CV) \\
$\begin{array}{l}\text { Improvement in the provision of } \\
\text { the good }\end{array}$ & $\begin{array}{l}\text { WTA to abstain from the im- } \\
\text { provement }\end{array}$ & Equivalent Variation (EV) \\
$\begin{array}{l}\text { Worsening in the provision of } \\
\text { the good }\end{array}$ & WTP to avoid the worsening & Equivalent Variation (EV) \\
$\begin{array}{l}\text { Worsening in the provision of } \\
\text { the good }\end{array}$ & WTA to accept the worsening & Compensating Variation (CV) \\
\hline \hline
\end{tabular}

Ahlheim \& Buchholz (2000) indicate that another important criterion should be the plausibility of the respective elicitation question to "normal" people (non-economists) in the specific context of the project to be valued. In the context of damage assessment after an environmental deterioration, the psychologically adequate question would aim for WTA. Furthermore, it has also been argued that individuals cannot individually purchase public goods (Graves 2003). So they will under-generate any income that would have been devoted to buy public goods. The marginal WTP observed for such goods will, as a consequence, be understated in economic and survey data relative to true values - so WTA should be used, argues Graves (2003: 1).

\subsection{The WTP/WTA anomaly}

Theory predicts in most of the cases in which SP techniques are used, that the divergence between WTP and WTA should be very small (see Bateman \& Willis 1999, Freeman 2003). High differences between WTP and WTA have been documented in the literature, however (see Brown \& Gregory 1999, Horowitz \& McConnell 2002). Empirically, it is common to find that stated WTA is much greater than stated WTP (see Sudgen 2005, Horowitz \& McConnell 2002). Extensive literature discusses the reasons of disparity between these two measures: income effects (Hanemann 1999), transaction costs (Randall \& Stoll 1980), loss aversion or endowment effect (Twersky \& Kanhneman 1991, Brown 2005) and emotions (Biel et al. 2006), among others. Also, the slope of concave indifference curves directly results in higher WTA values (see section 2.1).

According to Sugden (2005), anomalies in the context of stated preference techniques are sys- 
tematic patterns in individuals' responses that are inconsistent with the theory that is being used to organise the survey data. As mentioned above, one of the most prevalent anomalies is the observed divergence between two supposedly equivalent measures of economic value: WTA and WTP for the supply of environmental goods.

The preceding section presented a brief theoretical analysis of the two welfare measures, employed in the valuation of changes in the provision of environmental goods. The standard theory of preferences underpinning these welfare measures is predicated on the assumption that individuals have consistent preferences over all bundles of consumption of private and public goods, and that these preferences are independent of the context in which they are revealed. Hence, conventional economic theory postulates that, in most circumstances, the two measures of welfare change will yield approximately equal estimates of value (Willig 1976), with WTA exceeding WTP by, at most, a few percentage points. This small divergence between WTP and WTA is viewed by economic theory as a product of income and substitution elasticities (Hanemann 1999), i.e. with small income effects and many available substitutes, WTP for a commodity and the willingness to accept WTA compensation to sell the same commodity should be about equal. However, the general assumption of equivalence in gain (WTP) and loss (WTA) measures of value is refuted by a large body of empirical evidence demonstrating that WTA measures of value exceed estimates of WTP by a factor of at least two (Knetsch 1995). The frequency and regularity of such findings in the literature suggest that the magnitude of the WTA/WTP disparity cannot be attributed only to poorly designed surveys, or the presence of income effects and low elasticities of substitution in consumption.

The various reasons advanced for the WTA/WTP divergence draw on explanations that transcend the premises of traditional economics and put into question the suitability of standard economic theory (i.e. the Hicksian model) to accurately value welfare changes associated with the provision of public goods. The various alternative explanations, which include the endowment effect, ambiguity, legitimacy and moral responsibility are briefly discussed here, following Brown and Gregory (1999). 
Endowment effect. This explanation is based on behavioural aversion to losses and referencedependent preferences (Tversky and Kahneman 1991). It was first proposed by Thaler (1980) to suggest that goods are considered more valuable when they belong to one's endowment than when they do not. Essentially, endowment effect models people as evaluating prospective gains and losses in an asymmetrical way, weighing losses more than gains.

Ambiguity. Under conditions of high ambiguity about the characteristics of a good, risk averse sellers may tend to overestimate the value of a good to them, whereas risk averse buyers may underestimate its value. This is a plausible possibility in the case of complex environmental goods, whose characteristics are not very familiar to the respondents (on familiarity see e.g., Nunes \& Bergh 2001, Barkmann et al. 2006).

Legitimacy. Issues of legitimacy arise in transactions that involve ethical considerations. This is often the case for goods that are not traded commonly in the market place. People may have ethical qualms, and may therefore protest to placing monetary values on them. Examples are health, safety and species protection issues. On such issues people may be unwilling to accept a deterioration of environmental conditions in return for money, resulting in infinitely high values of WTA. ${ }^{1}$

Moral responsibility. The most well known incidence of moral responsibility in the literature is by Boyce et al. (1992), who demonstrated that people may have some sense of moral responsibility towards the protection of certain goods when the fate of these goods is placed under their responsibility. The feeling of moral responsibility, therefore, enhances the premium required by people to offset the potential destruction of the good in question, when this good is no more under their care.

\section{Stated preference methods in different planning stages}

SP techniques can contribute to decision making process not only on very different types of projects but also at very different stages of a project or policy planning process. One criterion to differentiate these different planning stages refers to the question (i) if alternative options or planning proposals have already been drafted at sufficient detail, or (ii) if concrete alternatives have, yet, to be designed.

\footnotetext{
${ }^{1}$ There are evidence, however, that the wide-spread occurrence of protests responses in such cases may be an artefact of the CV method avoided by carefully worded choice experiments (see Cerda et al. 2006a/b).
} 
Traditionally, contingent valuation surveys have focused on gathering preference information on select a well designed alternative. This focus is an implication of a methodological standard requirement for contingent valuation studies. Namely, the planning alternative to be valued by survey respondents must be described in sufficient detail with regard to quality and quantity including all relevant circumstances of the implementation of the project (see Mitchel \& Carson 1999). Obviously, such a requirement is nearly impossible to meet at very early planning stages because no detailed information is available at that time. The risk is high that the alternative finally up for decision bears little resemblance with some initial ideas at the start of the planning process. Consequently, decision-makers obtain only very limited support from result of contingent valuation surveys conducted at early planning stages.

On the other hand, it would be an undesirable restriction to the applicability of stated preference methods if they could not be used to inform also early planning stages. This is of specific importance with regard to more open, more participatory conservation planning procedures as required, for example, by the CBD Ecosystem Approach, the Sevilla Strategy for UNESCO Biosphere Reserves, or Sustainable Development and Agenda 21 processes in general. If citizens are to have an economic voice in such planning processes, already the design of suitable project alternatives must be informed by local preferences information. This requirement highlights the importance of stated preference data for early stages of the planning process, in which the optimised design of project alternatives is - always - a main challenge.

The utilisation of choice experiments offers an attractive solution to the problem of an optimised design of project alternatives. Compared to contingent valuation studies, CE has three main advantages here:

1. The project alternatives are defined by several attributes. This means that the influence of several aspects of the project alternatives can be assessed. These influences can include changes in the provisioning with ecosystem goods and services, but also important factors that refer to the implementation of the projects. Standard contingent valuation studies can only vary the 'price' of one complex alternative.

2. Each of the attributes can vary in terms of its levels. If the levels span the relevant range of 
realistic planning alternatives, the CE data allow for the generation of - linear as well as nonlinear - demand curves for the included attributes. This way, the same information can not be used only for an optimised design of project alternatives, it is also likely that the information can be used for decisions on final project variants.

3. Even if several aspects of the project to be valued in a contingent valuation study are varied by using several valuation questions within one instrument, only the experimental design principles of choice experiments allow for a systematic assessment of main effects and interaction effects of the aspects. This is the requirement for a true trade-off analysis, however.

These considerations resulted in the decision to use choice experiments in both case studies outlined in sections 4 and 6.

\section{Sustainable landscape planning in Chile}

\subsection{Case study background Chile}

After a few remarks on the location, socio-economic and ecological characteristics (sec. 4.1.1), we outline the administrative planning frame, in which the Chilean case study was carried out. This framework is characterized by the interplay of several authorities and administrative processes that are, in part, characteristic of the situation of the Island of Navarino, while other regulations apply to any landscape-level planning project in Chile.

\subsubsection{Case study location, socio-economic and ecological aspects}

The island of Navarino is located at the extreme south of America directly north of the Cape Horn Archipelago. Navarino is one of the few places in the world with temperate climate that has not been dramatically transformed by humans. This region contains one of few not fragmented and only slightly transformed temperate forests of the world. It is interesting to recognize how the perspective has changed from the old industrial view (which considered the archipelagos of the Cape Horn County to be depopulated and no developed lands) to a new ecological-economic view. This new view values these pristine and remote areas as a scarce resource which provides valuable services and ecosystem goods and offers an unique setting for the development of sus- 
tainable tourism (Rozzi et al. 2004: 12).

Up until the end of the 1990s, access to the island of Navarino was severely restricted due to military reasons. This can explain the continued existence of an extraordinary multiplicity of original habitats with a corresponding diversity of species groups such as mosses and lichens (Jax 2003, 2005). Also cultural diversity is high. Cultural diversity is the hallmark of the roughly 2,000 people living on the island, including the last surviving representatives of the island's original inhabitants, the Yaghans (Jax 2005). The about 2,000 citizens are mainly employed by the Chilean Navy, public administration and the fishing industry. Because of the remote location, Navarino can only be accessed regularly by air, and a weekly ferry. Right now, the island is only little dissected by infrastructure; the ecological impact of agricultural and tourist activity is low (Cerda et al. 2005). However, there exists a renewed interest in development of tourism and salmon farming which could significantly influence ecosystem function and species composition (Jax 2003). A transformation is therefore anticipated in the social and economic structures of the southernmost populated region of the Americas.

\subsubsection{Planning framework}

First, we will briefly address the formally well developed general framework of spatial planning in Chile. Second, the specific role of state administrations are highlighted. A third important set of planning processes is initiated by local authorities, namely the Municipality of Cape Horn and the Antarctic Province of Chile, both with their headquarters in Pt. Williams in Navarino, or by non-governmental organizations. The most important of these activities is the initiative to establish an UNESCO Biosphere Reserve that includes Navarino Island, the Local Agenda 21 and several activities to improve local tourism.

\section{Spatial planning in Chile}

The main legal frame to regulate territorial planning in Chile is the General Law of Urbane Planning and Constructions (Ley General de Vivienda y Urbanismo). The Ministry of Housing and Urban Planning, the regional governments as well as the local municipalities have the responsibility of applying this legal frame. At regional, inter-communal and communal levels of action, 
the territorial planning is effectuated by five instruments:

- The Regional Plan of Urban Development (Plan Regional de Desarrollo Urbano): which provides the guidelines for the development of urban areas of different regions of Chile. It coordinates the projections of the regional infrastructure.

- The Inter-Communal Regulator Plan (Plan Regulador Intercomunal): guides and regulates the physical development of urban and rural areas of several communes that, because of their relations, are integrated into one urban unit.

- Communal Regulator Plan (Plan Regulador Comunal): this instrument regulates the land use and zoning, localization of public utilities and establishment of urban priorities. Each commune of Chile has to develop a Regulator Plan.

- Sectional Plan (Plan Seccional): this instrument interprets four cases in which an ordenation of the physical space is produced by using a similar normative if compared to the Communal Regulator Plan. The differences with respect to the Communal Regulator Plan are related to the physical bound as well as to the specific objective of the Seccional Plan. In this sense, it is possible to identify four types of Sectional Plans: a) that substitute to the Communal Regulator Plans when these do not exist, b) relative to remodelling zones, c) relative to obligatory construction zones and d) those for the application of Communal Regulator Plans.

The procedures of approval of these planning are established in the Law of Urban Planning, the Constitutional Organization Law of Municipalities, the Constitutional Organization Law about Government and Regional Administration, and the Environmental Law 19.300.

For the case of Cape Horn County, a Sectional Plan for the island of Navarino has been designed in 2005. This plan will regulate the future land issue of Navarino. To our knowledge, this future local regulation is designed according to conservation goals as well economic development such as tourist infrastructure development in certain areas of the island. The Seccional Plan includes some locally controversial aspects. For its design, a consultant enterprise from the capital of Chile was contracted. The Sectional Plan is already approved by the Communal and Regional 
government councils. More than sixty local residents of Navarino expressed their concern with the Sectional Plan, and asked the Council of the Magallanes Region, authority of the region, to not to approve the Sectional Plan. The main controversy focuses on the north coast of Navarino. This is the most accessible region of the island, and was reserved by the Sectional Plan for investments at high scale. Consequently, many economically active inhabitants fear that the Plan would impede the development of micro-enterprises by Navarino inhabitants.

\section{Role of specific national administrations}

The Ministry of National Goods (Ministerio de Bienes Nacionales) manages and administers public lands owned by the Chilean state. The Ministry has decentralized regional offices. One of its faculties is to concede concessions of public lands to interested investors. Most parts of Navarino Island are state land, and therefore administered by Bienes Nacionales. There are very few private areas ${ }^{2}$. Today the interest for land concessions for the development of tourist activities is rising. Especially the west coast of Navarino is gaining importance. For example, general studies has been carried out at the west coast that describe the value of the tourist resources of Navarino (c.f. Rozzi et al. 2004). The lack of funding, staff and sufficient spatial information (Bienes Nacionales has no local office on Navarino island) makes the administration of these remote areas a difficult task, however. At the beginning of our project the Ministry of National Goods in the XII Region manifested strong interest in the economic valuation from our BIOKONCHIL subproject in order to facilitate agency decision making (meeting in October 2003).

The Ministry of National Defence has a strong role on Navarino with regard to the administration of the coast line. The coast line is of great social, economic and ecological importance. The Ministry of National Defence is represented on Navarino by the Maritime Governor office. At the same time, it is important to emphasize the role of the Chilean Navy. The Chilean Navy is extremely important on the island because of the bordering location with Argentina. For several years, high military tensions prevailed because of energy resources in the border region. During the Pinochet dictatorship, Navarino was only administered by the navy.

\footnotetext{
${ }^{2}$ This information was provided by: the Provincia Antártica Chilena's Governor (meeting in September 2003), the Ministry of National Goods in Punta Arenas (meeting in October 2003) and the National Forestry Corporation in Puerto Williams, Navarino island (meeting in September 2003).
} 
The navy personal in Navarino expressed strong support for the economic aspects of BIOKONCHIL research.

Other relevant public institutions are the National Forestry Corporation (CONAF), the National Environmental Commission (CONAMA), The Fishing National Service (SERNAPESCA), and the Agricultural and Livestock Service (SAG). CONAF administrates the national system of Protected Wilderness Areas (SNASPE). Additionally this institution regulates the forest management by national forest and environmental laws. CONAF is physically present on Navarino since 2002. This institution has one person in charge to supervise how the forestry activities are carried out. The presence of CONAF has implicated positive impacts with respect to illegal timber and fuel wood harvesting. CONAMA participates in designing regional environmental policies. The National Environmental Law (Ley 19.300 de Bases Generales sobre el Medio Ambiente) confers to CONAMA the coordination of Environmental Impact Evaluation Systems (SEIA). In 2002, CONAMA carried out a national survey of priority areas for biodiversity conservation. Some areas of the west side of Navarino were identified as priority sites. SAG belongs to the Ministry of Agriculture and contributes to increase the competitivity of the agricultural and livestock sector. SERNAPESCA oversees implementation of the Chilean Fishing Laws. SAG and SERNAPESCA are also physically present on the island.

\section{Local planning initiatives}

In 2002, our project partner on Navarino, the NGO Omora Foundation, proposed the idea of a Cape Horn Biosphere Reserve. This proposal involves the Cape Horn and Alberto D'Agostini National Parks, and the island of Navarino. Biosphere Reserves aim at harmonizing conservation and use of biological diversity. They provide an adequate frame for the planning and implementation of sustainable development on the island (Rozzi et al. 2004). The Biosphere Reserve proposal was written supported by BIOKONCHIL resources and data, in close cooperation with the local governor. The application was approved by UNESCO in June 2005. The Chilean Ministry of National Goods is particularly interested in the application of criteria that assure that new tourism projects are compatible with the conservation and sustainable development of the biosphere reserve. In the same way, the Provincial Government and the Cape Horn Municipality are 
strongly promoting this idea. However, the local planning carrying out these ideas has also a controversial character. As a strong political support was provided by the local government to Omora Foundation from 2002 to 2005, the proposal had to be reached before the new president elections in 2006. This because of the risk of new government agents on the island and consequently different management and ideas which could have affected the initiative. Additionally, as it would have taken additional time, no citizen participation was taken into account for the design of the zoning proposal. Even more, while applying our Choice Experiment in January 2005, most Navarino local residents had no idea that they could be part of a Biosphere Reserve. Once UNESCO gave the approval, the local government started to implement local participation by using the guidelines proposed by the Agenda 21.

Although the specific circumstances of the planning situation are less than ideal, the planning requirements are those of an early planning phase. Details of the Biosphere Reserve Management plan have not drafted yet; the local Agenda 21 process is at least open to a wide range of suggestions, and several of the authorities on the island have expressed interest in economic preference data to inform decision-making.

\section{Case study Chile}

\subsection{Methods}

\subsubsection{The choice experiment approach}

The CE method is based on Random Utility Theory (RUT) (McFadden 1973, Ben-Akiva \& Lerman 1985). Under RUT, the utility of a good is decomposed into an observable component, which is a function of a vector of attributes and respondent characteristics, and an unobservable error component. Given certain assumptions on the distribution of the error term, the probability of any particular option being chosen can be expressed in terms of logistic distribution (McFadden 1973). Combinations of levels taken by the attributes comprise specific scenarios that are selected from an universe of possible scenarios (Adamowicz et al. 1998). These scenarios are presented to survey respondents in series of choice sets, each containing usually three or more scenarios. From each choice set, respondents choose their preferred scenario. By repeating such choices, and systematically varying attribute levels, the researcher can infer which attributes in- 
fluence choice as well as the trade-offs among the set of attributes. When one of the attributes is a price, marginal WTP/WTA for an increase or decrease in any significant attribute can be estimated (Hanley et al. 1998).

\subsubsection{WTP-WTA design of the payment vehicle}

By applying 54 qualitative interviews, perceptions about biological diversity were explored. 14 interviews were immediately transcripted and analyzed (see Cerda et al. 2006). From an images of nature analysis of the qualitative input (Barkmann et al. 2005), the biodiversity attributes shown in Table 2 were selected for the study. The CE application in the main study used a mixed WTA-WTP format, via increases and decreases in income per month as the payment (= "price") attribute. The mixed WTP-WTA format, consisted in using three increases in income - i.e. the willingness-to-accept compensation (WTA) format - versus one decrease in income (see Tab. 2). The following reasons argue for this issue:

- Direction of changes: The current situation on Navarino is quite particular as the ecological situation is nearly ideal. The provision of important biodiversity services are not guaranteed in the long-term, however. As indicated in section 4.1.1, economic interests such as tourism and salmon farming could affect biodiversity negatively. Although conservation measures are also being planned by decision makers ${ }^{3}$, most actually contemplated "sustainable" development options for Navarino are likely to result in additional damage to biological diversity on the island. In sum, it is likely that the contemplated changes will result in a deterioration of biodiversity services. Additionally, declines in biodiversity can be interpreted as a loss in a factual property rights position of the local residents who enjoy only little restricted access to most of the island. This analysis called to use a mostly WTA compensation format, as only few attribute level combinations imply an environmental improvement.

\footnotetext{
${ }^{3}$ In fact, the future local regulation for the land issue of Navarino (Plan Seccional), establishes zoning rules based on conservation goals. Their implementation would represent an improvement from the Status Quo as some biodiversity services would be additionally protected.
} 
- Realistic scenarios/statistical power: CE requires the application of experimental designs to generate different combinations of attributes levels. Many studies have pointed to the necessity of using realistic scenarios - up to the suggestion to remove unrealistic scenarios from the experimental design (see e.g., Terawaky et al. 2003). Some combinations can result in unrealistic or non-logical scenarios. This may particularly occur when some scenarios, are predominantly above and below current levels while a WTP or WTA format is exclusively used. Such non-logical scenarios increase the risk of protest responses or nonrational decisions.

In our specific case, it was expected that most scenarios would, on average, show biodiversity services below current levels (see Tab. 2). However, improvements of some biodiversity services would also lead to obtain choice sets calling for a WTP issue. Thus, a negative change in income was also included.

Using the attributes and levels shown in Tab. 2, 32 different options were obtained from an orthogonal design main effects (Louviere et al. 2000). By using "mix and match" design strategies (Louviere 1988, Chrzan \& Orme 2000), these options were combined into choice sets with options $\mathrm{A}$ and $\mathrm{B}$, and one status quo option. The procedure using this mixed, mostly WTA versus one level WTP format, makes sure that most WTA situations make sense. However, some "miss-matches" can occur, because some combinations of attributes and levels could generate some options with lower/higher probability to be chosen by the respondents. Thus, the procedure can avoid protests responses but may also implicate some loss of statistical efficiency when options with lower/higher probability to be chosen are included. The options were assigned in four blocks of 8 choices each. One of the blocks was randomly assigned to each respondent. Fig. 2 shows exemplary alternatives used during the first choice experiment application.

- The frame and aims of the study: The CBD Ecosystem Approach provides the frame and guidelines of the study. Therefore, the research has a strong focus on participatory aspects. From this point of view, WTA and not WTP seemed more appropriated to be used. By using WTA, we hypothesized that the impact of respondent wealth on expressions of preferences would be low. Using a WTP format, the individual influence on aggregate WTP is bound by personal budget constraints. Consequently richer respondents gain an 
above average influence on the final valuation result.

Tab. 2: Attributes and levels used.

\begin{tabular}{|c|c|c|}
\hline $\begin{array}{l}\text { Valuation } \\
\text { dimension }\end{array}$ & Attribute & $\begin{array}{l}\text { Levels } \\
\text { (coding) }\end{array}$ \\
\hline $\begin{array}{l}\text { Aesthetic } \\
\text { quality of } \\
\text { landscape }\end{array}$ & $\begin{array}{l}\text { Change on landscape by impact of tourist } \\
\text { infrastructure }\end{array}$ & $\begin{array}{l}\text { Very small change }(-1)^{*} \\
\text { Small change }(+1) \\
\text { Medium change }(+1) \\
\text { Big change }(-2)\end{array}$ \\
\hline Access $^{4)}$ & $\begin{array}{l}\text { Access restrictions to nature by private } \\
\text { interests } \\
\text { Access restrictions to nature by } \\
\text { conservation interests }\end{array}$ & $\begin{array}{l}\text { Not restricted*(1) } \\
\text { Medium restricted (2) } \\
\text { Highly restricted (3) }\end{array}$ \\
\hline $\begin{array}{l}\text { Aesthetic } \\
\text { value }\end{array}$ & $\begin{array}{l}\text { Possibility to see animals } \\
\text { (woodpeckers, guanacos, cóndores) }\end{array}$ & $\begin{array}{l}25 \% \text { more than now }(+1) \\
\text { as now }(+2)^{*} \\
25 \% \text { less than now }(-2)\end{array}$ \\
\hline $\begin{array}{l}\text { Ethno } \\
\text { symbolic } \\
\text { value }\end{array}$ & The hummingbirds visit Navarino & $\begin{array}{l}\text { Not come to the island anymore }(-1) \\
\text { Not secure visit* }(0) \\
\text { Secure visit }(+1)\end{array}$ \\
\hline $\begin{array}{l}\text { Ecosystem } \\
\text { "health"5) }\end{array}$ & $\begin{array}{l}\text { Number of types of animals and plants } \\
\text { indicating the "health, resistance and } \\
\text { vigour of nature" }\end{array}$ & $\begin{array}{l}400 \text { types ("low health, vigour and resistance") } \\
800 \text { types ("medium...") } \\
1.600 \text { types ("high ...")* }\end{array}$ \\
\hline $\begin{array}{l}\text { Existence } \\
\text { value }\end{array}$ & $\begin{array}{l}\text { Probability of extinction of an endemic } \\
\text { moss }\end{array}$ & $\begin{array}{l}\text { Increased probability }(-1) \\
\text { Low probability }(1)^{*} \\
\text { Very low probability }(1)\end{array}$ \\
\hline $\begin{array}{l}\text { Payment } \\
\text { vehicle }\end{array}$ & Income change/month & $\begin{array}{l}\text { - } \$ 30.000 \text { Chilean pesos } \\
\$ 0 \text { Chilean pesos* } \\
+20.000 \text { Chilean pesos } \\
+30.000 \text { Chilean pesos } \\
+40.000 \text { Chilean pesos }\end{array}$ \\
\hline
\end{tabular}

Status Quo level; ${ }^{4)}$ a split sample differentiating access restrictions caused for private economic activities versus conservation projects; ${ }^{5)}$ this issue did not show up spontaneously in the qualitative interviews. The topic was regarded as a suitable way to introduce a systemic and long-term perspective into the valuation exercise, however. These economic insurance benefits correspond to benefits from the ecological insurance hypothesis on the effect of species diversity on the stabilization of ecosystem processes (c.f. Yachi \& Loreau 1999). ${ }^{6} 100 \mathrm{CHP} \sim 0.13$ Euro at the time of the main study. 
Fig. 2. Exemplary alternatives (translation from Spanish).

\begin{tabular}{|c|c|c|c|}
\hline Attributes & Option A & Option B & Status Quo \\
\hline $\begin{array}{l}\text { Change on landscape by im- } \\
\text { pact of tourist infrastructure }\end{array}$ & Small change & Big change & Very small change \\
\hline Income change/month & $\$ 0 /$ month & $+\$ 20.000$ & $-\$ 30.000$ \\
\hline $\begin{array}{l}\text { Number of types of animals } \\
\text { and plants }\end{array}$ & $\begin{array}{l}\text { 1600: Good health, } \\
\text { resistance and vigour } \\
\text { of nature }\end{array}$ & $\begin{array}{l}\text { 800: Middle health, } \\
\text { resistance and vigour } \\
\text { of nature }\end{array}$ & $\begin{array}{l}\text { 1600: Good health, } \\
\text { resistance and vig- } \\
\text { our of nature }\end{array}$ \\
\hline $\begin{array}{l}\text { Possibility to see animals } \\
\text { (carpinteros, guanacos and cón- } \\
\text { dores) }\end{array}$ & As often as now & $\begin{array}{l}25 \% \text { more often than } \\
\text { now }\end{array}$ & As often as now \\
\hline $\begin{array}{l}\text { Probability of extinction of an } \\
\text { endemic moss }\end{array}$ & Increased & Increased & Very low \\
\hline $\begin{array}{l}\text { Access restrictions to nature } \\
\text { (for private or conservation con- } \\
\text { cerns) }\end{array}$ & Medium restricted & Highly restricted & No restrictions \\
\hline $\begin{array}{l}\text { The hummingbirds visit the } \\
\text { island }\end{array}$ & $\begin{array}{l}\text { They do not come to } \\
\text { the island anymore }\end{array}$ & Not secure visit & Secure visit \\
\hline
\end{tabular}

After the main implementation and application of the CE main study, the outlined implementation of a mixed WTP-WTA format was complemented by a second survey, that used the design strategy explained in the following chapter 6, on the Kakamega forest valuation study.

\subsubsection{Administration of the survey and model estimation}

After the CE pilot study from February to April 2004, the CE questionnaire was administered sampling nearly every second household ( $\mathrm{n}=235$ ), from January to April 2005. For the stratification, the respondents were classified according to occupation categories (see INE 2002; National Census). Recruiting respondents from groups such as fishermen and construction workers required some snow-ball sampling. Therefore, the sample technique consisted of a mixture of systematic and snow-ball sampling.

Because violations of the IIA condition were observed for several multinomial logit models generated from the CE first phase data set $^{7}$, Nested Logit (NL) procedures that partly relax the IIA

\footnotetext{
${ }^{7}$ A Hausmann test (Hausmann \& McFadden 1984) was performed for the MNL model to test the assumption of the independence from irrelevant alternatives (IIA). To carry out the test, the MNL model was re-estimated on a subset of the alternatives.
} 
property (c.f. Hensher et al. 2005) were applied. The NL model tree structure was determined according to overall goodness of fit measure (log likelihood at convergence; Hensher et al. 2005: 494). The Inclusive Value of the degenerated branch was set to 1.0 (Hensher et al. 2005: 570). Scale parameters were normalized at the lowest level, called RU1 (Hensher et al. 2005: 538). The best fitting tree structure with an Inclusive Value (IV) between zero and 1 was selected (Hensher et al. 2005: 494). A weighting factor for each respondent observation was included to take account of stratification sampling bias. An alternative specific constant (ASC) was included, taking the value of 1 for the scenarios A and B, and 0 for the Status Quo option. It was the ASC role to take up any variation in choices that cannot be explained by either the attributes nor socioeconomic and attitudinal variables. The ASC was constrained to be equal for the alternatives A and $\mathrm{B}$ because a generic format was used to develop the choice sets.

\subsection{Results and discussion}

Two persons refused to complete the choice task and three respondents were classified as not responding to the CE task (two protests responses; insufficient cognitive capability to complete the task). 26 respondents ( $11 \%$ ) always choose the status quo. No respondent manifested doubts about the scenarios to be implemented. No one manifested questions about the payment vehicle being used.

From the basic Nested Logit model presented in Table 3, all attributes emerged as significant determinants of choice with exception of the possibility to see woodpeckers, guanacos and cóndores. Table 3 shows strong significance of the change on income attribute on the probability of choosing an option $(\mathrm{p}<0.001)$. The sign of the monetary attribute is positive, as expected, because the levels are mostly positive changes in income. The ASC coefficient results negative and significant indicating a negative utility associated with moving away from the status quo. This can be interpreted as a form of status quo bias (Samuelson \& Zeckhauser 1988) and appears to be a fundamental characteristic of the choice behaviour in our analysis. 
Tab. 3. Nested Logit Model ( $\mathrm{n}=230)$.

\begin{tabular}{|c|c|}
\hline Variable & Coefficient \\
\hline Change on landscape & $0.0947 * *$ \\
\hline Access Restrictions (private) ${ }^{\$}$ & $0.1532 * * *$ \\
\hline Access Restrictions (conservation) ${ }^{\$}$ & $0.1126 * *$ \\
\hline Possibility to see carpinteros, guanacos and cóndores & $\odot . \odot 299^{(n s)}$ \\
\hline Visits of hummingbirds with ethno-symbolic value & $\odot .5679 * * *$ \\
\hline Moss existence & $0.2413 * * *$ \\
\hline Ecosystem Health & $0.0006 * * *$ \\
\hline Income Change ${ }^{\S}$ & $0.0066 * * *$ \\
\hline ASC & $-0.2830 * *$ \\
\hline Log-likelihood & -1645.81 \\
\hline Restricted Log-likelihhod & -2109.17 \\
\hline $\mathrm{P}\left(\mathrm{Chi}^{2}\right) ; \mathrm{DF}$ & $<0.0001 ; 10$ \\
\hline Inclusive value (IV) ${ }^{\#}$ & 0.9913 \\
\hline Adj. $\rho^{2}\left(\text { Pseudo- } R^{2}\right)^{\S}$ & 0.2176 \\
\hline
\end{tabular}

***: significant at $\mathrm{p} \leq 0.001 ; * *$ : significant at $\mathrm{p} \leq 0.01 ; *$ : significant at $\mathrm{p} \leq 0.05 ;{ }^{\text {(ns) }}$ no significant $;{ }^{\$}$ raw coefficients multiplied with the sample means; ${ }^{\S}$ cost coefficients for $1,000 \mathrm{CHP} / \mathrm{yr} /$ household; DF: degrees of freedom; ${ }^{\#}$ all IV statistics are highly significantly different from 0 ; Nested Logit model based on 230 respondents with 8 choices each: $n=8 * 230=1840$ observations.

From the results in Table 3, marginal willingness-to accept values (WTA) for one "unit" of change as described by potential development scenarios for the island were calculated. The results are shown in Tab. 4. 
Tab. 4. Marginal WTA (in Chilean Pesos) $(n=230)$.

\begin{tabular}{|c|c|c|}
\hline Attribute & $\begin{array}{l}\text { "Marginal" unit } \\
\text { used for calculation } \\
\text { coding }\end{array}$ & $\begin{array}{c}\text { WTA } \\
{[\text { CHP/month] }}\end{array}$ \\
\hline $\begin{array}{l}\text { Change of landscape by impact of tourist } \\
\text { infrastructure }\end{array}$ & $\begin{array}{l}\text { Very small change }(-1) \text { to } \\
\text { small change }(+1)^{\S}\end{array}$ & 28,745 \\
\hline $\begin{array}{l}\text { Access restrictions to nature for private } \\
\text { concerns } \$\end{array}$ & Next restriction level & 23,257 \\
\hline $\begin{array}{l}\text { Access restrictions to nature for conservation } \\
\text { concerns } \$\end{array}$ & Next restriction level & 17,095 \\
\hline $\begin{array}{l}\text { Possibility to see woodpeckers, guanacos and } \\
\text { condores }^{\text {(ns) }}\end{array}$ & - & - \\
\hline The hummingbirds visit the island & $\begin{array}{l}\text { Next level of securing } \\
\text { humming bird presence }\end{array}$ & 86,222 \\
\hline Probability of extinction of an endemic moss & $\begin{array}{l}\text { Low probability of extinction }(+1) \\
\text { to increased probability of } \\
\text { extinction }(-1)^{\S}\end{array}$ & 73,269 \\
\hline $\begin{array}{l}\text { Number of types of animals and plants } \\
\text { indicating "health, resistance and vigour of } \\
\text { nature" }\end{array}$ & $\begin{array}{l}\text { Loss of } 1 \text { of } 1600 \text { species on the } \\
\text { island }\end{array}$ & 98 \\
\hline ASC & $\begin{array}{l}\text { Deviation from status quo as } \\
\text { offered by choices }\end{array}$ & $-42,969$ \\
\hline
\end{tabular}

Marginal WTA value is higher for access restriction by private concerns than for conservation, with a difference of $\sim 6,160 \mathrm{CHP} /$ month. We expected a negative utility associated with additional levels of restrictions. However, respondents actively accept access restrictions, specially if these restrictions are established in favour of private development initiatives. Most likely, the participants see some opportunities of employment and economic development for the island, not mentioned in the frame. The values for the landscape change attribute indicate that, on average, respondents also favour for increasing levels of tourist infrastructure impact on the landscape. Fomally this is expressed by a WTA of $28,700 \mathrm{CHP} /$ month. Because of the inverted U-shape utility curve, respondents require substantial compensation payments for big impacts, however. Marginal changes in the attribute levels on hummingbird presence result in the highest WTA values in excess of 86,000 CHP/month. Marginal WTA for the loss of one of about 1600 species on the island with respect to species contribution to the "health, vigour, and resistance of nature" is $\sim 100 \mathrm{CHP} /$ month. The ASC indicates that respondents, on average, have a status quo bias 
equivalent to $\sim 43,000 \mathrm{CHP} /$ month.

Although a detailed analysis is beyond the scope of this article, endowment effects on income can also be investigated using CE models. Since that both reductions and increases in income are used in the $\mathrm{CE}$, one can examine the utility of an increase versus a decrease in income. Reestimating the CE model, with a dummy variable to reflect alternatives that have decreases in income rather than increases in income, and interacting this variable with the change on income value itself, generates a variable that can be used to calculate marginal utility of increases versus decreases in income (for an example see Adamovicz et al. 1998).

Our design allows for a first assessment of the magnitude of the occurrence of the WTP-WTA anomaly in our study. Although very high deviations of WTA - from WTP - based preference surveys have been documented in the literature, we did not find support for systematic deviations. Our results indicate that choice experiments with mixed WTP-WTA formats may substantially reduce WTP-WTA deviations.

\section{Case Study Kenya}

\subsection{Setting of the Kakamega forest study}

The main purpose of this study is to measure the magnitude, in monetary terms, of the indirect and non-use benefits associated with the conservation of Kakamega forest in Kenya. The study is part of an organized attempt by BIOTA East Africa to estimate the Total Economic Value (TEV) (c.f. Pearce \& Moran 1994) of the forest to the communities residing around the forest. Kakamega forest is one of the remnants of the equatorial Guineo-Congolean rainforest in the Eastern fringes of Africa. As such, the forest is known for its diversity of biotic species, and it is home to some of the rarest flora and fauna in the East African region. It hosts a large number of rare animals and even some endemic plant species.

Only the data collection phase of the study has been completed. No data analysis has been undertaken yet and, therefore, no readily available results exist to present. Hence, the focus of this part will be on methodological considerations, especially ones pertaining to the choice and design of the valuation methods and the choice of the value-elicitation format. 
Following the pretesting stage, the experiment was administered to 320 respondents in face-toface interviews. Due to the big size of the sampling population, the respondents were picked using a stratified random sample.

\subsection{WTP-WTA designs}

Despite the extensive research that has been conducted on various levels of biodiversity in Kakamega forest, there is a remarkable paucity of data on the services provided by regulatory functions of the forest. This is unfortunate, since the estimation of the benefits from regulatory functions would help to demonstrate the true economic value of the forest. This renders the use of revealed preference methods for the estimation of the relevant indirect values virtually imposible. In the absence of data that facilitate the use of revealed preference methods, one has to resort to the second-best solution. Thus, in order to estimate indirect use values, as well as nonuse values, the use of stated preference techniques was deemed appropriate.

The chosen methods for measuring the values that the local population attaches to the services of the forest are Contingent Valuation (CV) and the Choice Modelling technique (CM). The reason for choosing to employ $\mathrm{CM}$ on top of $\mathrm{CV}$ is the additional information that will be obtained with regard to the values of specific attributes/services of the forest. The concurrent use of those techniques may also help to test for convergence between the values obtained from each of them, and potentially shed light on the existence or non-existence of systematic differences between these two closely related methods.

After a period of deliberation, pre-testing and literature reviewing, the following attributes, presented in Table 5 were chosen to be included in the choice experiment. The lack of data on values that could be used for the status quo levels of attributes such as soil loss and water availability, led to the use of an approach that conforms to individual perceptions of the prevailing environmental conditions. Thus, the 'soil loss' and 'water availability' attributes in the status quo scenario were not given a specific numerical value but this scenario was framed as a "no change" situation in the selected attributes, with the attribute levels in the other alternatives defined as percentage changes relative to the current situation.

Particular attention deserves the choice of the payment vehicle. The use of money is used almost universally as the payment vehicle of choice in CM and CV studies. In the case of Kakamega 
though, this was deemed inappropriate, because of the socio-economic situation of the relevant population. The subsistence nature of the local economy means that monetary transactions are not very widespread among local people, who, in most cases, are too poor to express WTP in monetary terms. Therefore, the payment vehicle was coined as "meals per week" contributed to a village development programme for one year. These meals would be provided by households to people working in the development programmes that would bring about the improvements in the selected environmental attributes. The average cost of a meal to the respondents was estimated to be 50 Kenyan Schillings (KShs). 
Tab. 5. Attributes and levels used in the Kakamega forest study.

\begin{tabular}{|c|c|c|c|}
\hline $\begin{array}{l}\text { Valuation di- } \\
\text { mension }\end{array}$ & Attribute & Levels & $\begin{array}{c}\text { Design } \\
\text { (WTP/WTA) } \\
\end{array}$ \\
\hline \multirow{5}{*}{$\begin{array}{l}\text { Indirect use } \\
\text { value }\end{array}$} & \multirow{5}{*}{$\begin{array}{l}\text { Water availability: } \\
\text { Amount of water available for } \\
\text { use during the dry season }\end{array}$} & $\begin{array}{l}40 \% \text { reduction in water } \\
\text { availability }\end{array}$ & WTA \\
\hline & & $\begin{array}{l}20 \% \text { reduction in water } \\
\text { availability }\end{array}$ & WTA \\
\hline & & & WTA/WTP \\
\hline & & $\begin{array}{l}20 \% \text { increase in water } \\
\text { availability }\end{array}$ & WTP \\
\hline & & $\begin{array}{l}40 \% \text { increase in water } \\
\text { availability }\end{array}$ & WTP \\
\hline \multirow{5}{*}{$\begin{array}{l}\text { Indirect use } \\
\text { value }\end{array}$} & \multirow{5}{*}{ Amount of soil loss per year } & $\begin{array}{l}\text { Amount of soil loss } \\
\text { doubles }\end{array}$ & WTA \\
\hline & & $\begin{array}{l}\text { Amount of soil loss } \\
\text { increases by } 50 \%\end{array}$ & WTA \\
\hline & & $\begin{array}{l}\text { No change in the } \\
\text { amount of soil loss* }\end{array}$ & WTA/WTP \\
\hline & & $\begin{array}{l}\text { Amount of soil loss } \\
\text { decreases by } 50 \%\end{array}$ & WTP \\
\hline & & $\begin{array}{l}\text { Amount of soil loss } \\
\text { stops (no soil loss) }\end{array}$ & WTP \\
\hline \multirow{5}{*}{ Bequest value } & \multirow{5}{*}{$\begin{array}{l}\text { Supply of forest products: } \\
\text { Number of years that the sup- } \\
\text { ply of forest products is se- } \\
\text { cured for }\end{array}$} & 10 more years & WTA \\
\hline & & 20 more years & WTA \\
\hline & & 30 more years* & WTA/WTP \\
\hline & & 60 more years & WTP \\
\hline & & 90 more years & WTP \\
\hline \multirow{5}{*}{ Payment vehicle } & \multirow{5}{*}{$\begin{array}{l}\text { Meals per week for one year } \\
\text { (contributed WTP or accepted } \\
\text { WTA as compensation) }\end{array}$} & No meals* & \\
\hline & & 1 meal & \\
\hline & & 2 meals & \\
\hline & & 3 meals & \\
\hline & & 4 meals & \\
\hline
\end{tabular}

* Status Quo.

This study aimed at obtaining values of both WTA and WTP. Underpinning the decision to measure WTA on top of WTP was the property rights situation in combination with an uncertain direction of future changes. Property rights in Kakamega forest reside de jure with the local communities, while the state manages the forest on behalf of these communities. However, over time the forest has been degraded significantly and, though it has recently been placed under a regime of strict protection, severe pressures remain. Therefore, while the direction of future changes in environmental conditions is indeterminate, it is quite likely that local populations will 
experience further declines in the quality or quantity of the services they receive from the forest.

Two designs were generated for the choice experiment application: one WTA and one WTP format. This approach was preferred because it would not generate any unrealistic alternatives that would have to be discarded, which might have compromised the statistical efficiency (i.e. orthogonality) of the design. Furthermore, the use of two different designs proved, during the pre-testing, simpler for the respondents to cope with, in the sense that it presented them with two separate but clear choice tasks, i.e. one WTP and one WTA choice: in the WTA (WTP) design, respondents were asked to choose among the status quo and two alternatives that were worse (better) than the status quo in all attributes except for the 'cost' attribute.

The attributes and levels in each format were combined using an orthogonal main effects design. This generated 8 combinations (profiles) for the WTA design and 8 combinations for the WTP design. The second profile in each of the 8 choice sets was created from the first profile using a "shifted" design (Chrzan and Orme 2000). The choice sets thus created were assigned in four blocks of four choice sets (two choice sets from the WTP design and two choice sets from the WTA). Each respondent was randomly assigned one of the four blocks.

Once the 4 choice tasks were completed, the respondent was presented with two contingent valuation questions, one eliciting WTP and one eliciting WTA. The two CV questions followed the same visual format as the CM tasks. Essentially, they were reduced versions of the CM choice sets, in the sense that instead of the status quo and two alternatives, they showed the status quo and one more alternative. A "payment card" elicitation format was used, whereby respondents were asked to choose their preferred amount (in terms of numbers of meals) from a list. 


\section{Conclusions}

The optimised design of project alternatives is a main challenge for the early stage of any realworld planning process. For participatory conservation planning procedures as required, e.g., by the CBD Ecosystem Approach, it is essential to involve concerned stakeholders - and their values - as early as possible in this design process. Particularly for non-market goods, stated preference methods can supply such information by using representative surveys. Thus, stated preference methods can be an important tool for informing conservation planning in line with the CBD Ecosystem Approach and similar guidelines.

In both case studies presented in this paper, a choice experiment as a specific stated preference method was used. The utilisation of choice experiments offers an attractive solution to some of the problems of an optimised design of project alternatives at early planning stages. A relevant but rarely discussed problem for the application of stated preference methods in early planning stages is the broad variety of development and/or conservation options potentially available. We showed that the ambivalence of the situation calls for the utilisation of mixed WTA-WTP survey formats. The versatility of the CE the methodology makes it possible to use both measures simultaneously within the same valuation survey instrument.

Materially, the results from the recently finished Chilean case study show that the "economic voice" of local residents of Navarino Island does not favour the development of large-scale tourism projects. Because local planning processes (e.g., Local Agenda 21, management plan for Biosphere Reserve) are in full swing, timely information is provided to local and regional decision-makers. For later planning stages, our data on the economic value of selected biodiversityrelated non-market goods and services can be used for the cost-benefit analysis of more detailed sustainable development options for Navarino Island.

Based on results from the Chilean case study, we document that a mixed WTP-WTA format allows obtaining meaningful marginal values for biodiversity services. Although very high deviations of WTA - from WTP - based preference surveys have been documented in the literature, 
we did not find support for systematic deviations. Although our study was not systematically designed to test hypotheses on the severity of the so-called WTP-WTA anomaly, our results indicate that choice experiments with mixed WTP-WTA formats may substantially reduce WTPWTA deviations. Furthermore, the chosen mixed WTP-WTA format of the payment vehicle contributed to the design and presentation of credible choice scenarios for participants. This advantage helped respondents to take all offered choice scenarios seriously; no single protest response arose from the choice tasks.

The Kenyan case study on Kakamega forest also operates in a fairly early ill-defined planning situation. The design procedures used assure systematically that no clearly implausible combinations of the offered environmental changes and the level of the monetary attribute occurs. Concurrently, the experimental design was used to optimise the design of the choice experiment with regard to potential WTP/WTA discrepancies. An additional benefit of the Kakamega forest study is that any discrepancy or convergence detected in the values obtained from the choice experiment can be compared to the closely related estimates from the two CV questions. Thus, the study introduces a set of value-convergence checks, not only within the choice experiment, but also across two different valuation techniques, namely $\mathrm{CE}$ and $\mathrm{CV}$.

In sum, our contribution highlights the versatility of the choice experiment method in early planning stages. In both case studies, the necessity to deal with the ambiguities of sustainable development and participatory planning processes led to the adoption of a format of the payment vehicle that includes WTP and WTA formats. By accident, this design feature of the case studies appears to shed light into one of the most intensively debated issues in stated preference research. 


\section{Literature}

Adamovicz W.L., Boxall, P., Williams, M. \& Louviere, J. (1998). Stated Preference Approaches for measuring passive use values: Choice Experiments and Contingent Valuation. American Journal of Agricultural Economics 80, 64-75.

Ahlheim, M. \& Buchholz, W. (2000). WTP or WTA - Is that the question?. Reflections on the differences between "willingness to pay" and "willingness to accept". Zeitschrift für Umweltpolitik und Umweltrecht 23, 253-272.

Arrow, K., Solow, R., Portney, P.R., Learner, E.E., Radner, R. \& Schuman, H. (1993). Report of the NOAA Panel on Contingent Valuation. Washington, D.C.: Resources for the Future.

Barkmann, J., Cerda, C. \& Marggraf, R. (2005). Interdisziplinäre Analyse von Naturbildern: Notwendige Voraussetzung für die ökonomische Bewertung der natürlichen Umwelt. Umweltpsychologie 9, 10-29.

Barkmann, J., De Vries, K., Dietrich, N., Glenk, K., Keil, A., Leemhuis, C. \& Marggraf, R. (2006). Confronting unfamiliarity with ecosystem functions: The case for an ecosystem service approach to environmental valuation with stated preference methods. Submitted (Ecological Economics).

Bateman, I \& Willis, K. G. (eds.). (1999). Valuing Environmental Preferences. Theory and Practice of the Contingent Valuation Method in the US, EU, and Developing Countries. Oxford (UK): Oxford University Press.

Bateman, I., Carson, R., Day, B., Hanemann, M., Hanley, N., Hett, T., Jones-Lee, M., Loomes, G., Mourato, S., Özdemiroglu, E., Pearce OBE, D.W., Sugden, R., \& Swanson, R. (eds.). (2002). Economic Valuation with Stated Preference Techniques: A Manual. Cheltenham (UK): Edward Elgar. 
Ben-Akiva, M. \& Lerman, S. (1985). Discrete Choice Analysis: Theory and Application to Travel Demand. Cambridge, MA: MIT Press.

Biel, A., Johansson-Stenman, O. \& Nilsson, A. (2006). Emotions, Morality and Public Goods: The WTA-WTP Disparity Revisited. Working papers in Economics No. 193. Department of Economics, School of Business, Economics and Law. Göteborg University

Boyce, R.R., Brown, T.C., McClelland, G.D., Peterson, G.L. \& Schulze, W.D. (1992). An experimental examination of intrinsic environmental values as a source of the WTA-WTP disparity. American Economic Review 82, 1366-1373.

Braga, J. \& Starmer, C. (2005). Preference Anomalies, Preference Elicitation and the Discovered Preference Hypothesis. Environmental \& Resource Economics 32, 55-89.

Brown, T. C. \& Gregory, R. (1999). Why the WTA-WTP disparity matters. Ecological Economics 28(3), 323-35.

Brown, T. (2005). Loss aversion without the endowment effect, and other explanations for the WTA-WTP disparity. Journal of Economic Behaviour \& Organization 57, 367-379.

Cerda, C., Barkmann, J. \& Marggraf, R. (2005). Assessment of Biological Diversity in the context of the CBD Ecosystem Approach: The Participatory Potential of Economic Valuation Techniques. Poster presentation at the international conference: "Biodiversity: Science and Governance". Paris, January 24-28, 2005.

Cerda, C., Barkmann, J. \& Marggraf, R. (2006a). Economic non-market evaluation of biological diversity of Navarino island, Kape Horn archipelago, Chile, in the context of the CBD Ecosystem Approach. Chapter III, this thesis.

Cerda, C., Barkmann, J. \& Marggraf, R. (2006b). Tradding-off the existence of an endemic 
moss? - empirical results at the extreme south of the Americas. Chapter IV, this thesis.

Chrzan, K. \& Orme, B. (2000). An Overview and Comparison of Design Strategies for ChoiceBased Conjoint Analysis. Sawtooth Software, Research paper series.

Diamond, P. (1996). Discussion of the conceptual underpinnings of the contingent valuation method by A. C. Fisher. In: Bjornstad, D. \& Kahn, J. (eds.): The contingent valuation of environmental resources: methodological issues and research needs (pp. 61-74). Cheltenham: Edward Elgar..

Freeman, A.M. (2003). The measurement of Environmental and Resource Values: Theory and Methods. $2^{\text {nd }}$ ed. Washington, D.C.: Resources for the Future.

Graves, P. (2003). The simple analytics of the WTA-WTP disparity for public goods. Boulder, CO 80309-0256. Department of Economics UCB 256. University of Colorado

Hanemann, M. (1999). The Economic Theory of WTP and WTA. In: Bateman, I. \& and K. Willis (eds.): Valuing Environmental Preferences. Theory and Practice of the Contingent Valuation Method in the US, EU, and developing countries (pp. 42-96). Oxford (UK): Oxford University Press.

Hanley, N., Wright, R. \& Adamowicz, W. (1998). Contingent Valuation versus Choice Experiments : Estimating the Benefits of Environmentally Sensitive Areas in Scotland. Journal of Agricultural Economics 49(1), 1-15.

Hanley, N., Mourato, S. \& Wright, R. E. (2001). Choice Modelling Approaches: A superior Alternative for Environmental Valuation?. Journal of Economic Surveys 15(3), 435-462.

Hausmann, J. A. \& McFadden, D. (1984). Specification tests for the multinomial logit model. Econometrica 46, 1219-1240. 
Hausman, J. A. (ed.). (1993). Contingent valuation: A critical assessment. The Netherlands: Elsevier Science Publishers B. V.

Hensher, D., Rose, J., Greene, W. (eds.) (2005). Applied Choice Methods - A Primer. Cambridge (UK): Cambridge University Press.

Horowitz, J. K. \& McConnell, K. E. (2002). A Review of WTA/WTP Studies. Journal of Environmental Economics and Management 44, 426-447.

INE (2002). Censo Nacional de Población. Instituto Nacional de Estadísticas. Chile. Available at: www.ine.cl.

Jax, K. (2003). BIOKONCHIL - Evaluation of Biological Diversity under the perspective of the Ecosystem Approach of the Convention on Biological Diversity, on the basis of the example of the island Navarino. In Sustainable use and conservation of biological diversity (pp: 374375). Bonn: PT-DLR Umweltforschung.

Jax, K. (2005). Navarino - ein gefährdetes Inselparadies. In: Roth, S. (Hrsg.): BioTeam - Biodiversitätsforschung für die Anwendung (S. 18-19). Berlin: Bundesministerium für Bildung und Forschung (BMBF).

Kahneman D. \& Tversky, A. (1979). Prospect theory: An analysis of decision under risk. Econometrica 47, 263-291.

Knetsch, J.L. (1995). Asymmetric valuation of gains and losses and preference order assumptions. Economic Inquiry 33, 134-141.

Louviere, J. (1988). Analysing Decision Making: Metric Conjoint Analysis. Sage University Paper Series on Quantitative Applications in the Social Sciences, 07-67. Beverly Hills: Sage. 
Louviere, J., Hensher, D. A. \& Swait, J. D. (2000). Stated Choice Methods - Analysis and Application. Cambridge (UK): Cambridge University Press.

Marggraf, R. \& Streb, S. (1997). Ökonomische Bewertung der natürlichen Umwelt. Theorie, politische Bedeutung, ethische Diskussion. Heidelberg/Berlin: Spektrum Akademischer Verlag.

McFadden, D. (1973). Conditional logit analysis of qualitative choice behaviour. In: P. Zarembka (ed.): Frontiers in Econometric (pp. 105-142). New York: Academic Press.

Mitchell, R. \& Carson, R. (eds.). (1989). Using Surveys to Value Public Goods: The Contingent Valuation Method. Washington, DC: Resources for the Future.

Nunes, P.A.L.D and v.d. Bergh, J.C.J.M., 2001. Economic valuation of biodiversity: sense or nonsense? Ecological Economics 39, 203-222.

Pearce, D. W. \& Moran, D. (1994). The Economic Value of Biodiversity. IUCN - The World Conservation Union. London: Earthscan.

Portney, P. R. (1994). The contingent valuation debate: Why economists should care. Journal of Economic Perspectives 8, 3-17.

Randall, A., \& Stoll, R. (1980). Consumer's Surplus in Commodity Space. American Economic Review 70, 449-55.

Rozzi, R., Massardo, F. \& Anderson, C. (eds.). (2004). The Cape Horn Biosphere Reserve: A Proposal for Conservation and Tourism to Achieve Sustainable Development at the Southern End of the Americas. Punta Arenas, Chile: Ediciones de la Universidad de Magallanes.

Samuelson, W. \& Zeckhauser, R. (1988). Status Quo Bias in Decision Making. Journal of Risk and Uncertainty 1, 7-59. 
Sugden, R. (1999). Alternatives to the neoclassical theory of choice. In: Bateman, I. \& Willis K.G. (eds.): Valuing Environmental Preferences: Theory and Practice of the Contingent Valuation Method in the US, EU, and Developing Countries (pp. 152-180). Oxford (UK): Oxford University Press.

Sudgen, R. (2005). Anomalies and Stated Preference Techniques: A Framework for a Discussion of Coping Strategies. Environmental and Resource Economics 32, 1-12.

Terawaki, T., Kuriyama, K., \& Yoshida, K. (2003). The Importance of Excluding Unrealistic Alternatives in Choice Experiment Designs. Discussion Paper No.03002. College of Economics, Ritsumeikan University.

Thaler, R., (1980). Toward a positive theory of consumer choice. Journal of Economic. Behavioural Organization 1, 39-60.

Tversky, A. \& Kahneman, D. (1991). Loss aversion in riskless choice: a reference-dependent model. Quarterly Journal of Economics 106, 1039-1061.

Willig, R.D. (1976) Consumer's surplus without apology. American Economic Review $66589-$ 597.

Yachi, S. \& Loreau, M. (1999). Biodiversity and ecosystem productivity in a fluctuating environment: the insurance hypothesis. - Proceedings of the National Academy of Sciences of the U.S.A. 96, 1463-1468. 


\section{Appendix}

\section{Appendix 1: Choice Experiment Questionnaire}

(Note that this is a translated version of the questionnaire. The original questionnaire was applied in Spanish. Words printed in italics were not shown or read to the respondents).

\section{BIOKONCHIL Project}

Economic Valuation of Biodiversity on Navarino island/Choice Experiment main questionnaire

University of Göttingen, Germany

PhD Student Claudia Cerda M.S., Dr. Jan Barkmann, Prof. Dr. Rainer Marggraf

Version 1 : Access restrictions for private economic activities

Block $N^{\circ}$

\section{Introduction}

Good morning/afternoon/night, my name is I am a scientist working for the German-Chilean Cooperation Project, BIOKONCHIL, here on Navarino island. I am interested in your opinion about possible changes to the landscape and economy of this place. Your information will be used for scientific purposes and it will be kept confidential. The aggregate anonymous results of our investigation will be given to the decisions makers for future decisions on the island. The interview focuses on your opinion, therefore there are not "right" or "wrong" answers.

\section{Frame}

Currently Navarino has a very varied landscape. The landscapes are important to many people here. They give recreation possibilities, water to drink, wood, centolla (king crab), fish. Many visitors admire the escenic beauty of the landscape. In a near future, however, some activities could change the landscape on the island. Some people want to build tourist infrastructure but others want strict conservation. Thus, the responses of our representative study will be used to inform, e.g., decision makers on the Biosphere Reserve and future tourism planing. Now, I am going to show you several cards sets. Each describes possible changes to nature and landscape. This changes represent a mixture of advantages and disadvantages for you. In each set, 
you have to choose the card that you prefer according how you would like that this changes were. Each card contains different elements of nature and landscape. I will explain the elements now. The cards look like this [One card was shown to the respondent].

\section{Explanation of attributes and levels}

a) Landscape change by tourist infrastructure

The first element of the cards is "landscape change by impact of tourist infrastructure".

Right now, there is only little infrastructure for tourism. This means few hostels, cabins, trails and roads. Most is concentrated in Puerto Williams. Some trekking trails have been implemented as well. The changes that this infrastructure has produced on the landscape have been very small. But now some people want to build infrastructure in places such as: Puerto Navarino, Cerro la Bandera, Dientes de Navarino and Wulaia [show pictures and map] what could result in changes to the landscape of the island.

a.1) Have you ever gone to these places?

o Yes

where did you go to?

[Got to a2] o No

If the respondent has never

gone to these places, select

one of them. Say: Imagine this

place [show pictures].

[Got to a2]

a.2) Imagine the landscape of the mentioned places and the possibility to build some infrastructure that changes these landscapes. For example, cabins and improved roads could be built. These changes will improve accessibility of the places for leisure and tourism but they could also change the beauty and solitude of the landscapes. In your personal opinion, which of the four places should be kept as much as possible in its current condition?

Please keep in mind those places that you already know or you have visited. 


\section{o P. Navarino o C. la Bandera o Wulaia o D. Navarino}

Why did you choose this place?

a.3) Suppose that in that place it is decided to build tourist infrastructure anyway. Then imagine one of 4 types of infrastructure that change that place:

- A first type is very low infrastructure. It results in very small change to the landscape. It means to have trekking trails and cabins of this type [show picture].

- A second type is low infrastructure. It results in small change to the landscape. It means a basic road, 4 cabins of the previous type and six cabins of this type. Also some places for picnic, and a small parking lot for cars [show picture].

- A third type is middle infrastructure. This results in medium change to the landscape. It means: a gravel road, 10 additional cabins of this type, an hostel with restaurant of this type and parking lot for cars [show picture].

- The last type is high infrastructure. This results in big change to the landscape. It means an asfalt road, 6 cabins of the previous type, an hotel of this type, souvenir shops and parking lots for cars and buses. [show picture].

Do you have any question?

a.4) Which do you think are the main advantages and disadvantages of implementing any type of tourist infrastructure in this place?, Could you mention advantages and disadvantages for very low, low and high infrastructure please? 


\begin{tabular}{|c|c|c|}
\hline Infrastructure level & Advantages & Disadvantages \\
\hline Very low & & \\
\hline Low & & \\
\hline High & & \\
\hline
\end{tabular}

\section{b) Ecosystem health}

Now I will explain this element of the cards. This refers to the health, resistance and vigour of nature.

One element for the health, resistance, and vigour of nature are the different types of animals and plants. Why? Well, we know some relationships in nature. For example, the woodpecker eats trees grubs. The hummingbird visits the Notro flowers to feed of their nectar. The beaver eats branches of the trees of forests. The centolla (king crab) eats fish rests. The calafate produces berries. The different animals and plants, even the humans depend of this web of relashionships. We eat centolla and use the trees for timber and housing, also we breathe the oxigen produced by plants. We know some of this relationships, even, we can see some of them. However there are many other relationships in nature that we know nothing about. The scientists discover new unexpected functions all the time. Many of the as yet unknown functions will not be important for us humans. But some may be critically important now or in the future.

This is a bit like the vigor, resistence and health of a person: The medical researches already know many functions of the types of cells and organs of the body. But they are constantly discovering new functions that contribute to our health, resistance and vigour.

How many different types of animals and plants do you think that are there on Navarino island?

Now, approximately $\mathbf{1 6 0 0}$ different types of animals and plants exist on the island. With 1600 types of animals and plants, the nature and landscapes of Navarino work quite well. With this 
number of types present, nature has always recovered from any fire, windstorm or other changes. This means that the health, resistance and vigour are high.

But what could happen with less type of animals or plants on the island? We can not exactly be sure. Maybe the nature of Navarino would not work quite well because some important animals and plants that we do not know would be missing. Then, the health of nature would be lower. Maybe important relationships for humans would be lost. Or perhaps, the nature could work quite well but it would be more susceptible to change. So the resistance to change would be lower.

What do you think?

Now imagine two cases. A first one in which these 1600 types of animals and plants decrease to 800. In the second case the number of types would decrease to $\mathbf{4 0 0 .}$

c) Possibility to see woodpeckers, guanacos and cóndores

Another element of the cards refers to the possibility to see woodpeckers, guanacos and cóndores.

c.1) Have you ever seen any of these animals here? [show pictures]

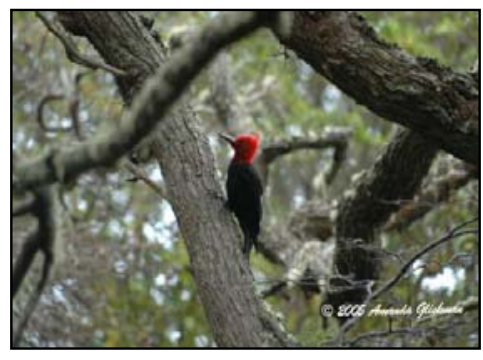

Carpintero

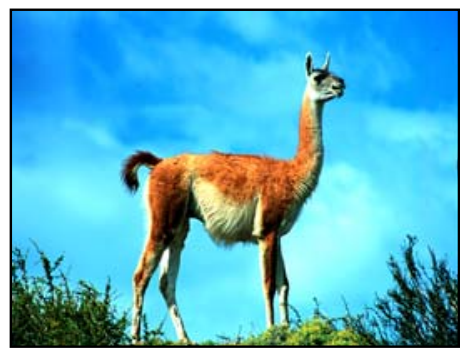

Guanaco

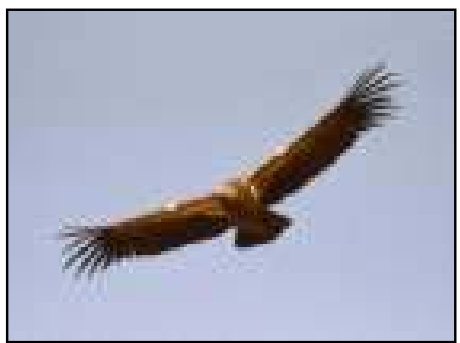

Cóndor

[Pictures shown to the respondent] 


\section{o Yes}

Which animal have you seen?

How often do you see it/them in one year?

Woodpecker

Guanaco

Cóndor

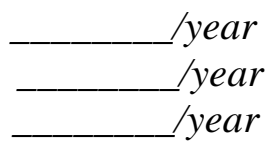

Where have you seen it /them?

Woodpecker

Guanaco

Cóndor

[Go to c2]. o No

Show picture.

[Go to c2].

c2) Imagine a scenario in which you could see them $25 \%$ more often than now, and another scenario in which you could see them $25 \%$ less often than now.

If the respondent asks how it could be, explain as follows:

- 25\% more could be due to application of scientific conservation projects.

- 25\% less could be due to disturbance from development activities.

Do you have any question?

d) Existence of an endemic moss

Now, I will refer myself to the fourth element of the cards.

Navarino is an important part of the sub Antarctic zone of Chile. In the sub Antarctic zone it is possible to find animals and plants which live exclusively in this part of the world.

d.1) Do you know about the existence of animals and plants that exclusively live in Navarino or the Sub Antarctic zone in general, and nowhere else in the world? 


\begin{tabular}{l} 
o Yes \\
Could you give me any example? \\
\hline [If the respondent does not mention \\
the mosses say: some mosses also]. \\
[Go to d2]
\end{tabular}

d.2) Do you know the mosses on the island?

o Yes

Could you tell me anything about them?

[Go to d3]. o No

Explain to the respondent: There are some animals and plants that exclusively live in the Sub Antarctic zone and nowhere else in the world, for example this moss [show picture].

[Go to d2].
[ No

They are those small plants growing on the tree trunks and in wet places and they are a bit like sponges.

[Show picture again] [Go to d3].

d3) Different types of mosses exist in the Sub Antarctic zone of Chile included Navarino island. Navarino is an important part of the habitat of many mosses. Often they are very similar and cannot be distinguished easily, even, some mosses can only be identified by experts. Scientists call a moss that lives only in this zone "endemic moss". "Endemic" means that the moss only exists in one place of the world. If eventually one of the endemic mosses disappeared from Navarino, which is an important part of its habitat, the probability that the moss disappears from the whole Subanctarctic zone increases. Because this moss is endemic of this zone, it would mean that it would disappear from the entire world and would go completely extinct.

Right now, this moss is not protected in Navarino. Still, its probability of extinction is low because it can be found in several places of the Subanctarctic region including the island of Navarino. 
Imagine two cases:

First: Some activities on the island of Navarino destroy by accident all places where the moss lives. Thus, the moss loses an important part of its life space. Consequently the moss can go extinct easily from its entire place of life in the Subanctarctic zone. The probability of extinction would increase.

Second: A few small areas are established on Navarino to protect specifically the life spaces of the moss. Then, in spite of some development activities, the moss continues to exist in all its life spaces on the island. Under these circumstances, the probability that the endemic moss goes extinct is very low because its important life places would be better protected than now of accidental damages.

Some people say: It is bad if the endemic moss disappears, some do not care.

What is your opinion?

o It is bad o It do not care

[Ask]: Why would it be bad if the moss [Ask]: Why not? disappeared?

\section{e) Access to nature}

This element of the cards refers to the access to nature. This is an island's map that I will use to explain you better [show map].

You have the possibility to enjoy the nature of this place practically without restrictions. You can go to the places without problems because the access is free and gratis. But maybe some restrictions could be established in the future.

Maybe with some tourism development you would not have the same possibilities that you have now to access places of Navarino. Imagine the following restriction scenarios: medium restricted access and highly restricted access. Assume please that it would occur by privatisations or concessions for private activities, for example tourism.

Medium restricted access means [show map]: that you could move freely along north coast but you would have restrictions to access some places in the north west of the island, it means: Bahía 
Wulaia and some places close to Puerto Navarino.

Highly restricted access means (show map): that you could move freely along north coast of the island. You would have the same restrictions as the previous case. But additionally, you would have additional restrictions to access Dientes de Navarino and Navarino Lake.

Do you have any question?

\section{f) The hummingbirds visit the island}

The last element of the card refers to a bird that visits the island. Its name is "colibri'" or "picaflor" [show picture].

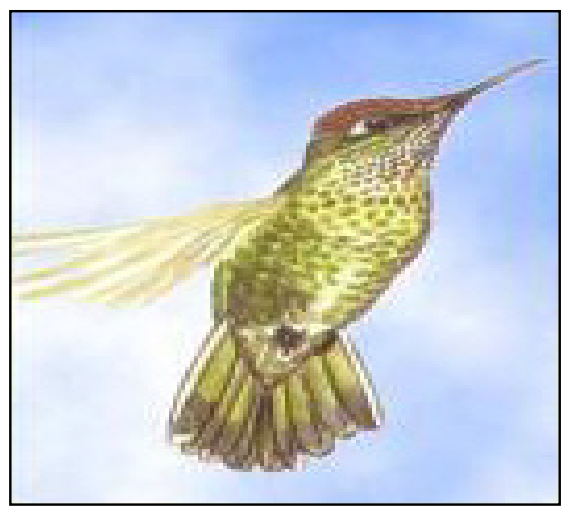

[Picture of the hummingbird shown to the respondent]

f1)Have you ever seen it here?
o Yes
o No

f2) Do you know anything about it? or have you heard anything about it?

o Yes

Could you tell me please?
O No

[Go to f3].

[Go to $f 3]$. 
f3) This "picaflor" plays an important role in the ancient stories of Yagan people. In this stories it is regarded as a bird but also as a little man or spirit that maintains the harmony between people and nature.

Did you know anything about these histories?
o Yes
o No

If yes: What did you know?

This bird is present on the island every autumn to feed on the Notro flowers. It then migrates to central Chile for the winter, because here gets too cold. The future changes on the island could implicate two effects: a) effective protection programs are established, therefore, the hummingbirds would continue visiting the island and would be protected; b) the habitat of the hummingbirds on Navarino is destroyed, therefore, they would not came to the island anymore.

Do you have any question?

\section{g) Change on income}

Finally, you can see here a change in income. In real life, many changes to the government policy can influence your income, for example, through subsidies or taxes. Also, investment decisions could affect your income by improving or worsening employment and business opportunities. Thus, the scenarios include a change in your income as well. This change is per month. Thus, the scenario that you choose would influence your income as you see here.

If you choose a scenario that costs your money, please keep in mind that you could buy or save less each single month by the specified amount.

\section{Choices}

What I explained to you is contained in these cards. Here you have a set of cards [show the first set]. This two cards represent each a scenario. Each describes possible changes on nature or landscape of the island related to what I explained to you before. This another one [show status quo] 
does not represent changes, it means, it represents the actual situation. If you do not think that the changes in card 1 or 2 improve your overall situation, simply choose the card three.

We will do this eight times with different cards.

Are you ready?

If yes go to 4.1

4.1 Rated by the interviewer.

\begin{tabular}{|c|c|c|c|c||}
\hline Choice set & A & B & SQ & Observations \\
\hline \hline 1 & & & & \\
\hline 2 & & & & \\
\hline 3 & & & & \\
\hline 4 & & & & \\
\hline 5 & & & & \\
\hline 6 & & & & \\
\hline 7 & & & & \\
\hline 8 & & & & \\
\hline \hline
\end{tabular}

Rated by the interviewer:

Time pressure the respondent seemed to feel

-3(none at all, very relaxed): +3(very much under pressure)

Emotional involvement to the valuation topic the participant seemed to feel

-3(none at all, very aloof): +3(very much emotionally involved)

4.2 Did any problems come to your mind while considering your choices?
o Yes
o No

If yes, please specify: 
4.3 Could you explain how did you proceed to choose the cards?

4.4 What information was the most important for you at the moment of choosing? You can mention information you got during the interview as well as information you have had before.

4.5 Could you distribute 9 points between these three animals according to which was the most important at the moment of taking your decision? (show picture)

Cóndor

Guanaco

Woodpecker points. points. points.

4.6 Which were the two most important elements of the cards to you?

Why?

4.7 Which were the two less important elements of the cards to you?

Why?

\section{Protection Motivation Theory questions}

In this section of the interview I would like to ask you some general questions about your personal opinion on the human-nature relation on Navarino. Please indicate for each statement if you agree or disagree. 


\begin{tabular}{|c|c|c|c|c|}
\hline $\begin{array}{l}\text { 1. To keep the actual landscape of the island is very important to } \\
\text { me. }\end{array}$ & $\begin{array}{r}\square \\
1\end{array}$ & $\begin{array}{l}\square \\
2\end{array}$ & $\square$ & $\square$ \\
\hline $\begin{array}{l}\text { 2. It is not very likely that strong changes will occur on the } \\
\text { island. }\end{array}$ & $\begin{array}{r}\square \\
1\end{array}$ & $\begin{array}{l}\square \\
2\end{array}$ & $\begin{array}{r}\square \\
3\end{array}$ & $\square$ \\
\hline $\begin{array}{l}\text { 3. To keep the health, resistance and vigour of nature, is not of } \\
\text { interest to me. }\end{array}$ & $\begin{array}{c}\square \\
1\end{array}$ & $\begin{array}{l}\square \\
2\end{array}$ & $\begin{array}{r}\square \\
3\end{array}$ & $\square$ \\
\hline $\begin{array}{l}\text { 4. A low health, resistance and vigour of nature could have } \\
\text { disastrous long-term effects for Navarino island. }\end{array}$ & $\square$ & $\begin{array}{l}\square \\
2\end{array}$ & $\square$ & $\square$ \\
\hline $\begin{array}{l}\text { 5. To have the possibility to see woodpeckers, guanacos and } \\
\text { cóndores is very important to me. }\end{array}$ & $\square$ & $\begin{array}{l}\square \\
2\end{array}$ & $\square$ & $\square$ \\
\hline 6. The existence of the endemic moss is very important to me. & $\begin{array}{c}\square \\
1\end{array}$ & $\begin{array}{l}\square \\
2\end{array}$ & $\begin{array}{r}\square \\
3\end{array}$ & $\square$ \\
\hline 7. If the endemic moss disappears, it is a big problem for nature. & $\begin{array}{c}\square \\
1\end{array}$ & $\begin{array}{l}\square \\
2\end{array}$ & $\square$ & $\begin{array}{l}\square \\
4\end{array}$ \\
\hline $\begin{array}{l}\text { 8. To access most of the places on the island freely, is very } \\
\text { important to me. }\end{array}$ & $\begin{array}{l}\square \\
1\end{array}$ & $\begin{array}{l}\square \\
2\end{array}$ & $\begin{array}{l}\square \\
3\end{array}$ & $\begin{array}{r}\square \\
4\end{array}$ \\
\hline $\begin{array}{l}\text { 9. I can do something for the continued visits of the } \\
\text { hummingbirds. }\end{array}$ & $\begin{array}{l}\square \\
1\end{array}$ & $\begin{array}{l}\square \\
2\end{array}$ & $\begin{array}{l}\square \\
3\end{array}$ & $\begin{array}{l}\square \\
4 \\
\end{array}$ \\
\hline
\end{tabular}

\section{Sociodemographic questions}

In this section of the questionnaire I would like to know some general information about you and your family

6.1 Could you say me your age please?

.years old.

6.2 What is your occupation on the island?

6.3 Could you say me your number of years of study from basic teaching? years.

6.4 Do you have children?

o Yes $\quad$ o No 
6.5 How long do you live on the island? years /or months.

6.6 How long will you live on the island? years/or months.

6.7 Does your net personal income in the last 12 months, classify in one of these ranges? (show card)

1) You do not have direct income

2) $\$ 100.000$

3) Between $\$ 101.000$ y $\$ 200.000$

4) Between $\$ 201.000$ y $\$ 300.000$

5) Between $\$ 301.000$ y $\$ 400.000$

6) Between $\$ 401.000$ y $\$ 500.000$

7) Between $\$ 501.000$ y $\$ 600.000$

8) Between $\$ 601.000$ y $\$ 700.000$

9) Between $\$ 701.000$ y $\$ 800.000$

10) Between $\$ 801.000$ y $\$ 900.000$

11) More than $\$ 900.000$

For the interviewer:

The person does not respond

The person does not know

\section{General questions}

7.1 Do you have any comment about this questionnaire?

o Yes

o No

If yes: Could you explain me please?

Thanks a lot for your collaboration and time !!!

8. General data rated by the interviewer

8.1 The respondent is:

o Male o Female

8.3 The attitude of the respondent to the interview was:

$\boldsymbol{o}$ Good $\boldsymbol{o}$ Indifferent $\boldsymbol{o}$ Without willingness 


\section{Publications and meetings}

\section{Publications}

Barkmann, J., Cerda, C. \& Marggraf, R. (2005). Interdisziplinäre Analyse von Naturbildern: Notwendige Voraussetzung für die ökonomische Bewertung der natürlichen Umwelt. Umweltpsychologie 9, 10-29.

Cerda, C. (2005). Valuing biological diversity in Navarino Island, Cape Horn Archipelago, Chile: A choice Experiment Approach. Treffpunkt Biologische Vielfalt 4, 149-154.

\section{Meetings}

"Biodiversity Science and Governance", International Conference organised by the French Ministry of Science, January 2005, UNESCO, Paris. (poster).

"Valoración Económica de Servicios Ambientales", Conferencia Internacional, October 2005, Universidad de Talca, Talca, Chile. (poster).

"Integrating biodiversity science for human wellbeing", DIVERSITAS Open Science Conference, November, 2005, Oaxaca, Mexico. (talk).

Wissenschaftlicher Workshop zur Bewertung von Nicht-Marktgütern in Deutschland, Österreich und der Schweiz, November 2005, Umweltforschungszentrum, Leipzig. (talk).

Interdisziplinäres Expertentreffen im Rahmen des Übereinkommens über die biologische Vielfalt, Internationale Naturschutzakademie Insel Vilm, August 2005, Bundesamt für Naturschutz. (talk).

Statusseminar des BioTeam-Forschungsprogramms im Rahmen der BMBF-Forschungsinitiative zur Biodiversitätsforschung, March 2005, Wissenschaftszentrum Bonn. (poster). 
36th Annual Conference of the Ecological Society of Germany, Switzerland and Austria (GfÖ), September 2006, Bremen, Germany. (accepted talk).

International Congress Ecosystem Services in the Neotropics: State of the Art and future challenges, November 2006, Universidad Austral de Chile, Valdivia, Chile. (accepted talk). 


\section{Curriculum vitae}

Personal information

Name:

Claudia Loreto Cerda Jiménez

Date/place of birth:

21.5.1975 in Santiago de Chile

Academic antecedents

July 2003-May 2006

PhD-student at the Department of Agricultural Economics, Environmental and Resource Economics

Georg-August-University of Göttingen

Chair: Prof. Dr. Rainer Marggraf

April 2000-April 2002

Master student - Environmental Management and Planning Inter-faculties Master Program,

Universidad de Chile

M. S. Environmental Management and Planning, June 2003

March 1993-December 1998

Bachelor student of Forestry

Forestry Faculty

Universidad de Chile

Work Experience

Professional title: Forestry Engineer, December 2000

July 2003-May 2006

March 2003-July 2003

March 2000-Jun 2003

Consultant associated at the Wood Chilean Corporation (CORMA)

Project: Forests for Chile

January 2001-May 2001

Consultant associated at the Forestry National Corporation (CONAF), Chile

Project CONAF/GTZ: Sustainable Management of Chilean Native Forests 
January 1999-March 1999

Professional Practice at the Environmental Department of Lomas Bayas Mining Company. $2^{\text {nd }}$ Region of Chile 
